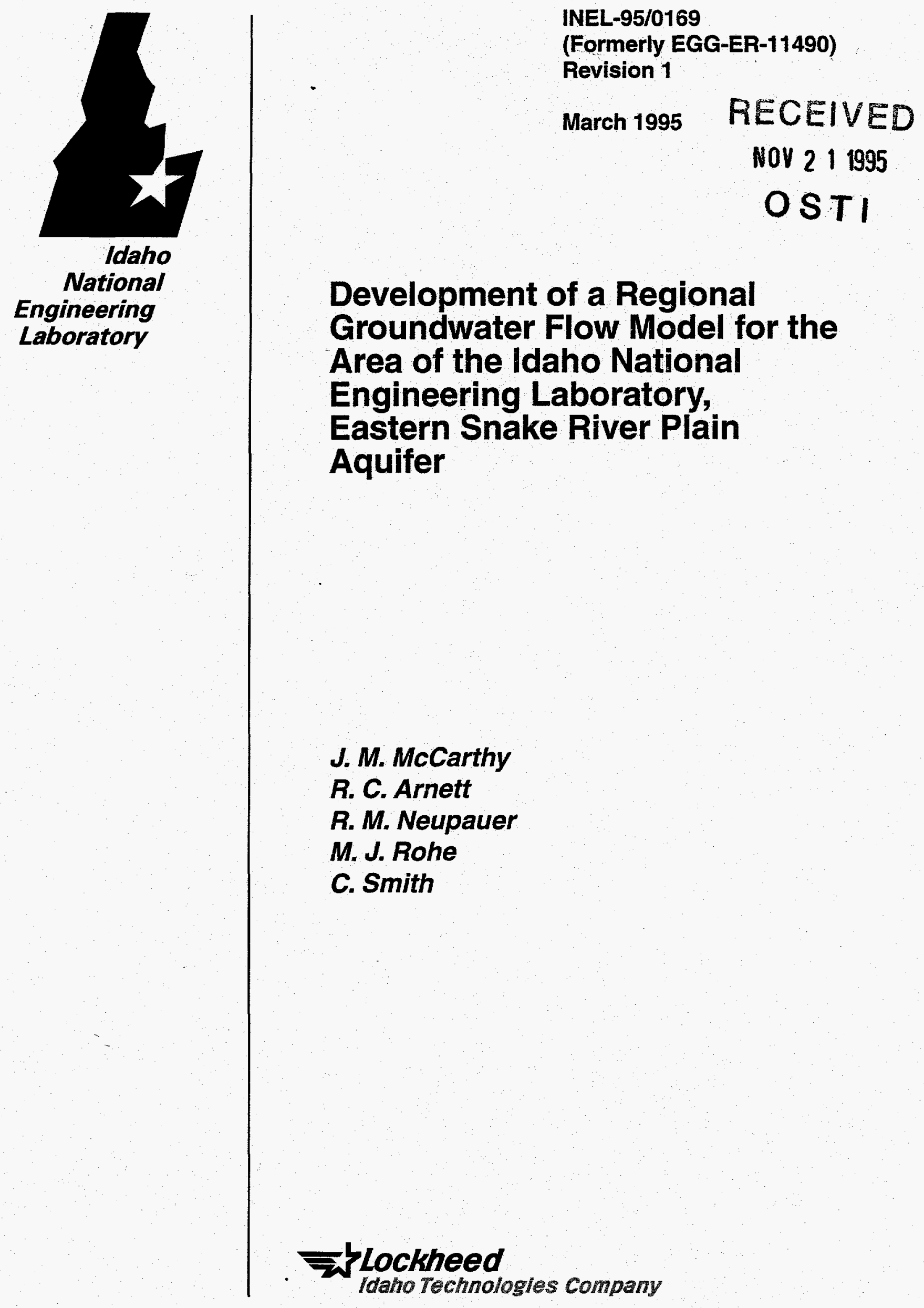




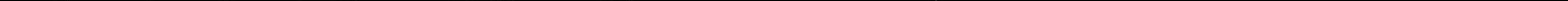


This report was prepared as an account of work sponsored by an agency of the United States Government. Neither the United States Government nor any agency thereof, nor any of their employees, makes any warranty, express or implied, or assumes any legal liability or responsibility for the accuracy, completeness, or usefulness of any information, apparatus, product, or process disclosed, or represents that its use would not infringe privately owned rights. Reference herein to any specific commercial product, process, or service by trade name, trademark, manufacturer, or otherwise does not necessarily constitute or imply its endorsement, recommendation, or favoring by the United States Government or any agency thereof. The views and opinions of authors expressed herein do not necessarily state or reflect those of the United States Government or any agency thereof.
INEL-95/0169

(Formerly EGG-ER-11490)

Revision 1

\title{
Development of a \\ Regional Groundwater Flow Model for the Area of the Idaho National Engineering Laboratory, Eastern Snake River Plain Aquifer
}

\author{
J. M. McCarthy \\ R. C. Arnett \\ R. M. Neupauer \\ M. J. Rohe \\ C. Smith
}

Published March 1995

\section{Idaho National Engineering Laboratory Groundwater Restoration Lockheed Idaho Technologies Idaho Falls, Idaho 83415}

\author{
Prepared for the \\ U.S. Department of Energy \\ Assistant Secretary for Environmental Restoration \& Waste Management \\ Under DOE Idaho Operations Office \\ Contract DE-AC07-94ID13223
}





\section{Development of a Regional Groundwater Flow Model for the Area of the \\ Idaho National Engineering Laboratory, Eastern Snake River Plain Aquifer}

INEL-95/0169

(Formerly EGG-ER-11490)

Revision 1

Sie C. Will for S.w. Bum

Susan M. Burns, Manager

WAG 10

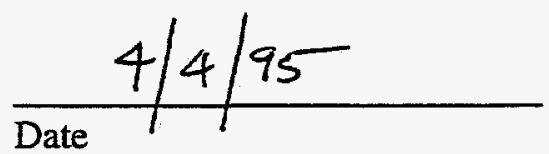

Date 



\section{ABSTRACT}

This report documents a study conducted to develop a regional groundwater flow model for the Eastern Snake River Plain Aquifer in the area of the Idaho National Engineering Laboratory. The model was developed to support Waste Area Group 10, Operable Unit 10-04 groundwater flow and transport studies. The products of this study are this report and a set of computational tools designed to numerically model the regional groundwater flow in the Eastern Snake River Plain aquifer.

The objective of developing the current model was to create a tool for defining the regional groundwater flow at the INEL. The model was developed to (a) support future transport modeling for WAG 10-04 by providing the regional groundwater flow information needed for the WAG 10-04 risk assessment, (b) define the regional groundwater flow setting for modeling groundwater contaminant transport at the scale of the individual WAGs, (c) provide a tool for improving the understanding of the groundwater flow system below the INEL, and (d) consolidate the existing regional groundwater modeling information into one usable model. The current model is appropriate for defining the regional flow setting for flow submodels as well as hypothesis testing to better understand the regional groundwater flow in the area of the INEL. The scale of the submodels must be chosen based on accuracy required for the study. 


\section{CONTENTS}

1. INTRODUCTION

1.1. Purpose and Scope

1.2 Background.

1.3 Previous Modeling Investigations ...

1.4 Modeling Objective $1-6$

2. HYDROGEOLOGIC SETTING

2.1 Geology 2-1

2.1.1 Surface Geology 2-1

2.1.2 Subsurface Geology 2-1

2.2 Hydrology 2-1

2.2.1 Precipitation $2-1$

2.2.2 Evaporation. 2-1

2.2.3 Surface Water $2-4$

2.2.4 Groundwater $2-4$

3.1 Model Domain 3-1

3.2 Water Budget

3.2.1 Snake River 3-3

3.2.2 Streams, Canals, Lakes, and Ponds

3.2.3 Irrigation 3-14

3.2.4 Precipitation 3-14

3.2.5 Underflow 
4.1.1 Basic Package ..................................................................... 4-1

4.1.2 Output Control Package .................................................... 4-8

4.1.3 Block Center Flow Package ............................................. 4-8

4.1.4 River Package .............................................................. 4-8

4.1.5 Recharge Package ................................................... 4-8

4.1.6 Well Package ............................................................... 4-8

4.1.7 Drain Package............................................................. 4-12

4.1.8 General-Head Package .................................................. 4-12

4.1.9 Preconditioned Conjugate Gradient Package ................ 4-12

4.1.10 Stream Package ............................................................. 4-12

4.2 MODFLOWP Input................................................................... 4-12

4.2.1 Hydraulic Conductivity Parameter Definition............... 4-15

4.2.2 Hydraulic Head Observations for Calibration............... 4-17

4.2.3 Integrating Previous Models Hydraulic Conductivity Zones ..........................................................4-17

4.2.4 Major Inconsistencies Between MODFLOW and MODFLOWP …................................................ 4-20

5. MODEL CALIBRATION .................................................................... 5-1

5.1 Calibration Process ....................................................................... 5-3

5.1.1 General Calibration Approach Using MODFLOWP ...... 5-3

5.1.2 Calibration Approach Used for this Study ...................... 5-4

5.1.3 Calibration Targets for Heads, Fluxes, and Parameters .. 5-5

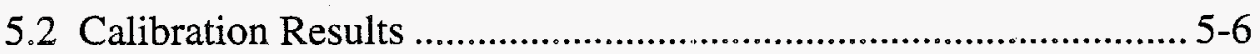

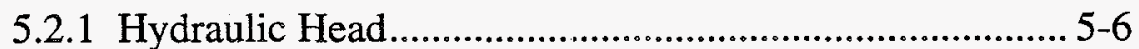

5.2.2 Hydraulic Head Gradient................................................ 5-25

5.2.3 Water Budget................................................................ 5-38

5.2.4 Parameter Value Range ……….................................. 5-38

5.2.5 Parameter Reliability ................................................. 5-41 
6.1 Hydraulic Conductivity Values $6-1$

6.2 Boundary Conditions-Underflows $6-3$

6.3 River Conductances, Vertical Hydraulic Conductivity, Recharge, and Pumping $6-8$

7. MODEL LIMITATIONS $7-1$

8. MODELING AND EVALUATION TOOLS $8-1$

9. METHOD FOR DEVELOPING A LOCAL-SCALE MODEL $9-1$

10. SUMMARY $10-1$

11. REFERENCES $11-1$

Appendix A-STEADY-STATE PARAMETER ESTIMATION PACKAGE INPUT FILE A-1

Appendix B-COMPARISON OF THE SIMULATED VERSUS THE

MEASURED HYDRAULIC HEADS FOR THE TRANSIENT MODEL B-1

Appendix C-COMPUTATIONAL TOOLS FOR REGIONAL GROUNDWATER FLOW MODEL .C-1

Appendix D—RECORD OF COMMENTS REVIEW D-1 


\section{FIGURES}

1-1. Location of the Idaho National Engineering Laboratory......................................... 1-3

2-1. Estimated average annual precipitation over the domain over the Snake River drainage basin upstream of King Hill.

2-2. Measured long-term precipitation and the cumulative departure from the mean at rain gauges at Aberdeen and Ashton.

2-3. Tributary basins and surface water features.

2-4. Spatial distribution of the average annual pumping rates over the entire domain. . 2-6

3-1. Contour map of the aquifer depth in layer 3

3-2. Contour map of the aquifer depth in layer 4 $3-2$

3-3. Reaches defining gains and losses along the Snake River. $3-4$

3-4. Snake River losses to (-) and gains from (+) groundwater, 1912-1980. $3-6$

3-5. Reaches defining losses along the Big Lost and Little Lost Rivers and Reservation, Aberdeen Springfield, and Milner-Gooding Canals.

3-6. Model underflow boundaries and location of major gauging stations along the Big Lost River, Little Lost River, and Birch Creek.

3-7. Recharge to the aquifer from surface water irrigation within the domain. 3-15

3-8. Tributary drainage basin underflow reaches. 3-19

3-9. Arco-Test well hydrograph used as an index for the Big Lost River underflow... 3-24

3-10. Sweet-Sage well hydrograph used as an index for the Little Lost River underflow.

3-11. USGS-025 well hydrograph used as an index for the Birch Creek underflow.... 3-26

3-12. Hydraulic conductivity zones defined in the Garabedian model. $3-28$

3-13. Hydraulic conductivity zones defined in the Spinazola model. 3-29

3-14. Hydraulic conductivity zones defined in the EIS model. 3-30

3-15. Hydraulic conductivity zones defined in the FY 93 WAG 10 model. 3-31 
3-16. Hydraulic conductivity zones defined in the current model.

4-1. Basic Package input file for the pseudo steady state (1980) simulation. $4-2$

4-2. Garabedian model numerical model domain and discretization (4 $\mathrm{x} 4$-mi grid)..... 4-3

4-3. Spinazola model numerical model domain and discretization ( $1 \times 1$-mi grid) ...... 4-4

4-4. EIS model numerical model domain and discretization. $4-5$

4-5. FY 93 WAG 10 model numerical model domain and discretization. $4-6$

4-6. Current model numerical model domain and discretization ( $1 \times 1$-mi grid). 4-7

4-7. Output Control Package input file for the pseudo steady-state (1980) simulation.

4-8. Block Center Flow Package input file.

4-9. River Package input file for the pseudo steady-state (1980) simulation. $4-10$

4-10. Recharge Package input file for the pseudo steady-state (1980) simulation....... 4-11

4-11. Well Package input file for the pseudo steady-state (1980) simulation. $4-11$

4-12. Drain Package input file for the pseudo steady-state (1980) simulation. 4-13

4-13. General-Head Package input file for the pseudo steady-state (1980) simulation.

4-14. Preconditioned Conjugate Gradient Package input file. 4-14

4-15. Stream Package input file for the pseudo steady-state (1980) simulation. 4-14

4-16. Top portion of Data Set 2 of the example Parameter Estimation Package input file.

4-17. Hydraulic head observations defined in Data Set 6 of the Parameter Estimation Package input file. $4-18$

5-1. INEL map and WAG locations.

5-2. Observation well locations. $5-10$

5-3. Difference map comparing the areal match between simulated and field-measured heads for the 21 key wells. 
5-4. Difference map comparing the areal match between simulated and field-measured heads for the 21 key wells plus 27 additional wells used to define the regional hydraulic head distribution throughout the area of the INEL..... 5-21

5-5. Contour map showing the areal match between the current model simulated heads (solid lines) and the Garabedian model simulated heads (dashed lines).

5-6. Contour map showing the areal match between the current model simulated heads (solid lines) and the Spinazola model simulated heads (dashed lines).

5-7. Comparison of the simulated and measured hydrographs for one well at each WAG.

5-8. Methodology for calculating flow direction and average hydraulic gradient from the hydraulic head at three observation well locations.

6-1. Sensitivity coefficient map for the Big Lost River underflow. 6-5

6-2. Sensitivity coefficient map for the Little Lost River underflow. 6-6

6-3. Sensitivity coefficient map for the Birch Creek underflow. 6-7

8-1. Aquifer temperature versus depth below the water table (in meters) 8-3

9-1. Hypothetical boundaries of an example subarea model located on the regional model grid. 9-3 


\section{TABLES}

2-1. Distribution of estimated transmissivity at and near the Idaho National Engineering Laboratory $2-11$

3-1. Layer depths used in Garabedian (1992) and Spinazola (1994a) models. $3-1$

3-2. Snake River losses to and gains from the aquifer, water year 1980. 3-5

3-3. Snake River water elevation and conductance values used at and between gauging stations.

3-4. Average annual tributary-stream and canal losses to the groundwater system. .... 3-11

3-5. Losses in reaches along the Big Lost River 3-13

3-6. Comparison of various estimated average annual (or 1980) underflows from tributary drainage basins.

3-7. Mean annual volume of precipitation for each tributary basin and the percentage attributed to the tributary basin underflow.

3-8. Groundwater budget, water year 1980 .

3-9. Comparison of the layer $1 \mathrm{~K}$ values used for the current model and the factors used to calculate the $\mathrm{K}$ values in layers 2,3 , and 4

4-1. Model layer depths.

5-1. Twenty-one key wells and corresponding WAGs.

5-2. Target range for the $\mathrm{K}$ values $(\mathrm{ft} / \mathrm{sec})$.

5-3. Layer 1 average storage coefficient (or specific yield) values.

5-4. Comparison of measured and simulated hydraulic heads for the calibration run with the 21 key wells weighted heavier than the other 27 wells.

5-5. Final $\mathrm{K}$ values and coefficients of variation for each of the $12 \mathrm{~K}$ zones.

5-6. Comparison of measured and simulated hydraulic heads for the calibration run when all 48 wells are equally weighted.

5-7. Mean and standard deviation of the transient model simulation residuals for the key wells. 
5-8. Comparison of simulated to measured hydraulic head gradients and flow directions across in the area of each individual WAG and over the site (WAG 10).... 5-34

5-9. Comparison of simulated to measured hydraulic head gradients and flow directions at the intermediate scale in the vicinity of WAGs 2 through 7 .

5-10. Comparison of simulated gains and losses in the Snake River with the measured values and values estimated by Garabedian.

5-11. Comparison of layer $1 \mathrm{~K}$ values for the current model and those used for select previous studies

6-1. Sensitivity analysis grids.

6-2. Sensitivity coefficients for each K parameter zone at each of the WAG areas. 6-2

6-3. Sensitivity coefficients for each underflow area at each of the WAG areas. 6-4

6-4. Sensitivity coefficients for the river conductance, vertical hydraulic conductivity, recharge, and pumping at each WAG area. $6-9$ 


\section{ACRONYMS and ABBREVIATIONS}

$\begin{array}{ll}\text { ANL-W } & \text { Argonne National Laboratory-West } \\ \text { CFA } & \text { Central Facilities Area } \\ \text { DOE } & \text { U.S. Department of Energy } \\ \text { DOE-ID } & \text { U.S. Department of Energy Idaho Operations Office } \\ \text { EBR-I } & \text { Experimental Breeder Reactor No. 1 } \\ \text { EPA } & \text { U.S. Environmental Protection Agency } \\ \text { ESRP } & \text { Eastern Snake River Plain } \\ \text { ICPP } & \text { Idaho Chemical Processing Plant } \\ \text { INEL } & \text { Idaho National Engineering Laboratory } \\ \text { K } & \text { hydraulic conductivity } \\ \text { NRF } & \text { Naval Reactors Facility } \\ \text { OU } & \text { operable unit } \\ \text { PBF } & \text { Power Burst Facility } \\ \text { RASA } & \text { Regional Aquifer-System Analysis } \\ \text { RI/FS } & \text { Remedial Investigation/Feasibility Study } \\ \text { RWMC } & \text { Radioactive Waste Management Complex } \\ \text { T } & \text { transmissivity } \\ \text { TAN } & \text { Test Area North } \\ \text { TRA } & \text { Test Reactor Area } \\ \text { USGS } & \text { U.S. Geological Survey } \\ \text { WAG } & \text { waste area group } \\ & \\ & \end{array}$





\section{DEVELOPMENT OF A REGIONAL GROUNDWATER FLOW MODEL FOR THE AREA OF THE IDAHO NATIONAL ENGINEERING LABORATORY, EASTERN SNAKE RIVER PLAIN AQUIFER}

\section{INTRODUCTION}

This report documents a study conducted to develop a regional groundwater flow model for the Eastern Snake River Plain (ESRP) aquifer in the area of the Idaho National Engineering Laboratory (INEL). The model was developed to support Waste Area Group (WAG) 10, Operable Unit 10-04 (OU 10-04) groundwater flow and transport studies.

The products of this study are this report and a set of computational tools designed to numerically model the regional groundwater flow in the ESRP aquifer. The set of computational tools includes a regional groundwater flow model, preprocessing codes, postprocessing codes, and data evaluation codes. A data base of WAG 10related documents is also included. Input files for the regional groundwater flow model are provided on a floppy disk in the back of this report. All other files can be obtained from the Hydrogeologic Data Repository maintained by WAG 10 .

The model is a tool for improving the understanding of the groundwater flow system. For the tool to be useful, it must be used and updated as information is gathered and insight is gained into the groundwater flow system.

\subsection{Purpose and Scope}

WAG 10 is responsible for performing the regional-scale Remedial Investigation/ Feasibility Study (RI/FS) at the INEL. The WAG $10 \mathrm{RI} / \mathrm{FS}$ will integrate the results of each WAG's RI/FS. The RI/FS process involves current data collection and interpretation, historical data and record assembly and interpretation, computer modeling as necessary to predict contaminant transport, and assessment of present and future risks to human health and the environment. Therefore, a consistent approach is needed for groundwater modeling to

(a) make technically sound decisions and

(b) assure the public that the U.S. Department of Energy (DOE) has adequately evaluated the risk to the public and the environment from contamination at the site.

Several regional scale groundwater flow and transport models have been developed that include the INEL area. The results of these studies can be found in Robertson (1974), Garabedian (1992), Arnett et al. (1990), Rood et al. (1989), and Goode and Konikow (1990). Reviews of these reports are presented in Arnett et al. (1993) and McCarthy et al. (1994). Existing computer models and reports are useful sources for developing a WAG 10 regional flow model tool; however, they (a) do not focus on groundwater flow over the INEL area at a useful scale for the WAG 10 modeling and (b) do not contain currently available information necessary to simulate the physical mechanisms that govern flow in the ESRP aquifer. This regional scale model (referred to as the current model) integrates the models developed in the past into a useful tool for modeling groundwater flow in the vicinity of the INEL.

MODFLOWP was used to develop the current groundwater flow model. The U.S. Geological 
Survey (USGS) code MODFLOWP (Hill 1992) is a new version of MODFLOW that incorporates a nonlinear regression, Parameter Estimation Package. MODFLOW (McDonald and Harbaugh 1988) is a transient, three-dimensional, finite difference groundwater flow simulation code.

This report is presented in 11 chapters. Chapter 1 provides the purpose and scope of the study and an overview of previous modeling investigations. Chapters 2 and 3 present the logic and assumptions of the groundwater flow conceptual model. The MODFLOW and MODFLOWP tools used for data analysis and groundwater flow simulation are presented in Chapter 4. Chapter 5 presents model calibration results, and Chapter 6 discusses the groundwater flow model sensitivity to model parameters. Chapter 7 describes limitations to the groundwater flow modeling, Chapter 8 summarizes the tools developed to conduct data analysis and groundwater flow simulation, and Chapter 9 provides the methodology for using these tools to define the groundwater flow regional setting. A summary of the study is presented in Chapter 10, and Chapter 11 contains a list of references cited in this report.

\subsection{Background}

The INEL was established in 1949 as the National Reactor Testing Station, a place where the Atomic Energy Commission could build, test, and operate nuclear reactors, support facilities, and equipment. Today, the INEL is a DOE facility occupying approximately $890 \mathrm{mi}^{2}$ in southeastern Idaho (see Figure 1-1) and overlaying a portion of the $10,800 \mathrm{mi}^{2}$ ESRP aquifer. During past operations at the INEL, radioactive and chemical wastes were released directly to the aquifer or to shallow wells, placed in ponds, or buried where they could potentially migrate to the aquifer.

Contaminant concentrations exceeding drinking water standards have been found in groundwater wells at the INEL. As a result of this and other problems, the INEL was placed on the National Priority List on November 21, 1989, by the U.S. Environmental Protection Agency (EPA). This action subjected the INEL to requirements of the Comprehensive Envirormental Response, Compensation, and Liability Act. To comply with environmental regulatory requirements, DOE Idaho Operations Office (DOE-ID) has established the Environmental Restoration Program to evaluate the environmental impacts of past contaminant releases and to take appropriate actions, as necessary, to protect human health and the environment. Regulatory oversight is provided by the EPA Region X and the State of Idaho Department of Health and Welfare. The legal framework existing between the State of Idaho Department of Health and Welfare, EPA, and DOE-ID is contained in a Federal Facilities Agreement and Consent Order. The Federal Facilities Agreement and Consent Order, signed on December 9, 1991, and the associated action plan established actions to be taken to bring the INEL into compliance with applicable regulations.

The INEL has been divided into 10 WAGs, which were further divided into operable units (OUs) and sites. The first nine WAGs are facility-specific (WAG 1 through WAG 9). The final WAG (WAG 10) includes miscellaneous surface sites and liquid disposal areas throughout INEL that are not included within other WAGs. WAG 10 also includes regional Snake River Plain Aquifer concerns related to the INEL that cannot be addressed on a WAGspecific basis. The ESRP aquifer is one of the five OUs (OU 10-04) in WAG 10.

This report focuses on groundwater flow in the ESRP aquifer in the area of the INEL. 


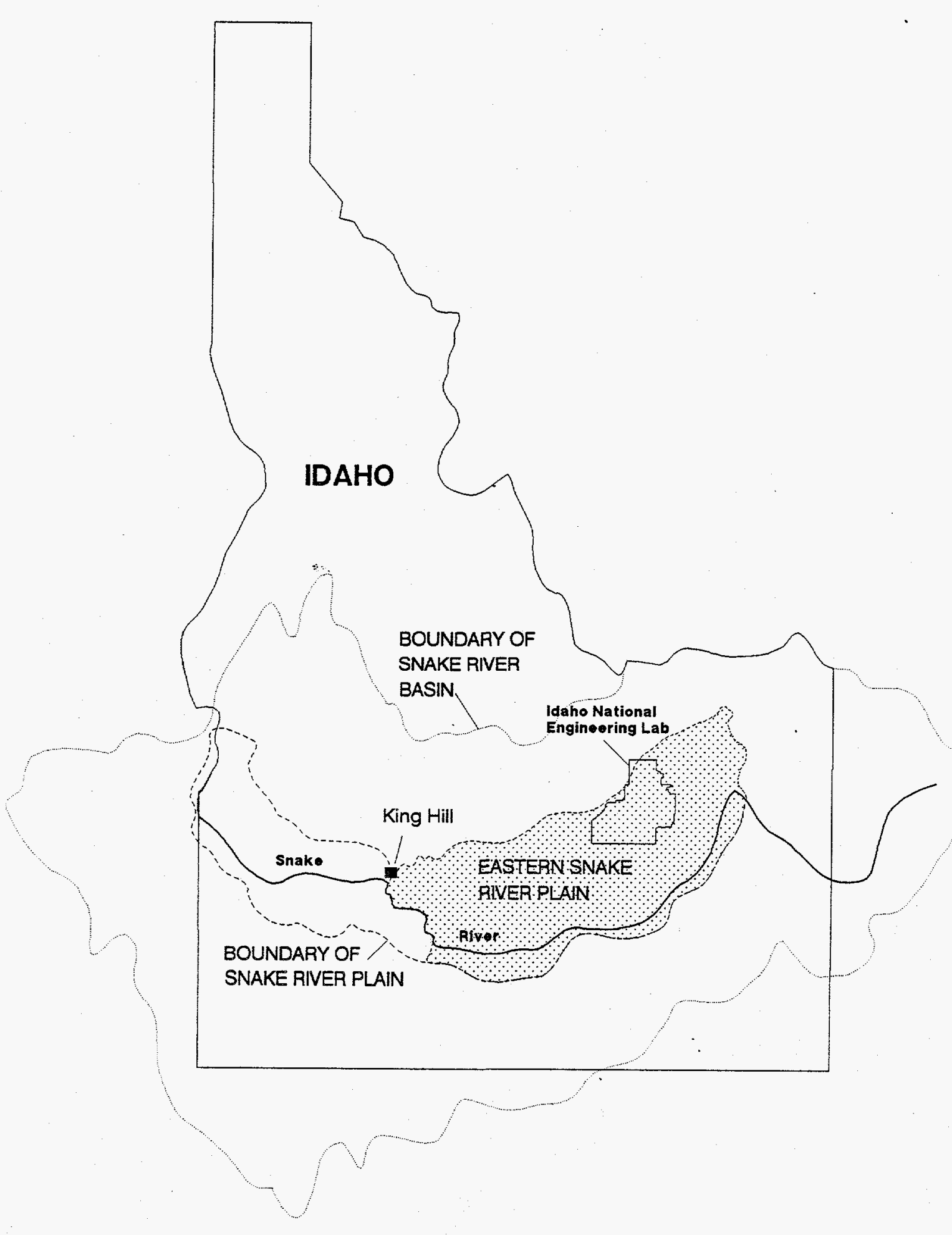

Figure 1-1. Location of the Idaho National Engineering Laboratory. 
However, the WAG 10 groundwater modeling investigations conducted over the last 3 years have evaluated both flow and transport. The following documents were prepared during the course of WAG 10 groundwater investigations:

- Groundwater Flow Model Data and Bounding Assumptions for Model Calibration (Arnett and Brower 1993)

- Hydrologic/Hydraulic Data Needed for WAG 10 Groundwater Flow Modeling of the Snake River Plain Aquifer (OU 10-04) (Arnett and McCarthy 1993)

- Basis for Initial Code Selection for WAG 10 Groundwater and Contaminant Transport Modeling at the Idaho National Engineering Laboratory (Arnett et al. 1993)

- Analysis of Iodine-129 Trends in the Aquifer Beneath the Idaho National Engineering Laboratory (Arnett 1993a)

- Information Transfer and Coordination of Groundwater Flow and Transport Between WAG 10 and WAGs 1 Through 9 (McCarthy and Arnett 1993)

- Review of the Current and Planned Modeling Efforts for WAGs 1-9 (McCarthy 1993a)

- Testing of WAG 10 Groundwater Flow and Transport Codes (McCarthy 1993b)

- Contaminant Plume Chemistry and Other Data Needed for WAG 10 Groundwater Contaminant Transport Modeling (Arnett 1993b)

- Preparation of Preliminary WAG 10 Simulation Models (McCarthy 1993c)

- Geochronologic Tracing of Contaminant Transport in Radioactive Groundwater Plumes (Norrell et al. 1993)
- WAG 10 Preliminary Groundwater Flow Model Calibration (McCarthy and Neupauer 1993)

- Critical Evaluation of the Use of Available Data for Regional Model Calibration (McCarthy and Rohe 1994)

- Summary of WAG 10 Groundwater Modeling Results for FY-93 (McCarthy et al. 1994).

\subsection{Previous Modeling Investigations}

The ESRP aquifer has been studied by numerous investigators. Modeling investigations are described in Robertson $(1974,1977)$ updated by Lewis and Goldstein (1982), Johnson et al. (1984), Garabedian (1986), Goode and Konikow (1990), Arnett et al. (1990), Arnett and Springer (1993), Garabedian (1992), Spinazola (1994a), and McCarthy et al. (1994).

Groundwater flow models presented in Garabedian (1992), Spinazola (1994a), McCarthy et al. (1994), and Arnett and Springer (1993) are of particular interest to this study. Garabedian (1992) is the most comprehensive of past groundwater modeling investigations of the entire ESRP aquifer. The most recent investigations are Spinazola (1994a, 1994b), which focus on the Mud Lake area of the ESRP aquifer upgradient of the INEL, and McCarthy et al. (1994) and Arnett and Springer (1993), which focus on the INEL vicinity.

The study documented in Garabedian (1992) was conducted under the USGS Regional Aquifer-System Analysis (RASA) Program. Studies conducted as part the of the RASA Program (a) refine knowledge of the regional groundwater flow system, (b) determine the effects of conjunctive use on groundwater and surface water ${ }_{f}$ and (c) describe the chemistry 
of groundwater. The results of the RASA program provide the most comprehensive set of hydrogeologic and water budget information available upon which to base a regional groundwater model. The study documented in Garabedian (1992) refined and extended knowledge of the regional groundwater flow system in the ESRP aquifer. The model developed (referred to as the Garabedian model) is a three-dimensional finite difference model (using MODFLOW, McDonald and Harbaugh 1988) of the entire ESRP aquifer. The Garabedian model and the current model use the same domain. The water budget information used in the Garabedian model is the best and most complete available; therefore, for the most part the current model uses the water budget information from Garabedian (1992). Like the Garabedian model, the current model simulates the entire ESRP aquifer; however, unlike the Garabedian model, the current model focuses on the INEL area.

A major objective of the current model is to develop a tool for defining the regional groundwater flow setting for the specific WAGs to simulate local-scale groundwater flow to define contaminant transport. The current model uses the Garabedian model to develop this tool, refining the finite difference discretization from $4 \times 4 \mathrm{mi}$ to $1 \times 1 \mathrm{mi}$, adding detail to the boundary conditions in the INEL vicinity, and substituting the more recent information developed by Spinazola (1994a) upgradient from the INEL.

The purpose of the Spinazola (1994a) investigation was to obtain a better understanding of the geohydrology of the Mud Lake area upgradient for the INEL and develop a tool to evaluate water-use alternatives. The calibrated model developed (referred to as the Spinazola model) is a steady-state, three-dimensional, finite difference model (using MODFLOW) of a
$2,200 \mathrm{mi}^{2}$ area upgradient of the INEL. The northern part of the INEL falls in the domain modeled by Spinazola, but it was not the focus of Spinazola's modeling study. With the exception of the recharge from irrigation, the Spinazola and Garabedian models use the same steady-state water budget information. Spinazola (1992a, 1992b) estimated monthly water budget components from 1980 to 1990 , but Spinazola does not use the transient information in his model simulations.

The purposes of the McCarthy et al. (1994) investigation were originally to (a) predict regional contaminant migration for risk assessment, (b) organize large volumes of field data to improve the understanding of flow and transport processes in the ESRP aquifer below the INEL, and (c) provide a tool to interface and coordinate information exchange with facility-specific WAG models. The model developed (referred to as the FY 93 WAG 10 model) is a steady-state twodimensional, finite difference model (using MODFLOWP, Hill 1992) of the INEL and vicinity. Difficulties were encountered defining the water budget for this model; the current groundwater modeling effort adopted the domain and water balance approach used by Garabedian to develop a useful tool for WAG 10 groundwater modeling.

The purpose of the Arnett and Springer (1993) investigation was to develop a groundwater flow model to simulate transport from liquid contaminant sources at the INEL for the Department of Energy Spent Nuclear Fuel Management and INEL Environmental Restoration and Waste Management Programs Draft Environmental Impact Statement (DOE 1994). The calibrated model developed (referred to as the EIS model) simulates either steady-state or transient groundwater flow. It is a finite difference model (using MODFLOW) of the INEL and vicinity. The EIS model accurately simulated the measured 
hydraulic heads over the area of the INEL. However, the water budget through the domain could not be accurately controlled because most of the boundary conditions were defined as prescribed head rather than flux boundary conditions based on the regional water budget. Extending the model domain to the entire ESRP aquifer allows the regional water budget applied in Garabedian (1992) to be incorporated directly into the groundwater flow model.

\subsection{Modeling Objective}

The objective of developing the current model was to create a tool for defining the regional groundwater flow at the INEL. The model was developed to

- Support future transport modeling for OU $10-04$ by providing the regional groundwater flow information needed for the OU 10-04 risk assessment

- Define the regional groundwater flow setting for modeling groundwater contaminant transport at the scale of the individual WAGs

- Provide a tool for improving the understanding of the groundwater flow system below the INEL

- Consolidate the existing regional groundwater modeling information into one usable model.

To accomplish the modeling objective, nine tasks were performed:

1. Hydrogeologic data were compiled.
2. Hydrologic evaluation tools were developed to analyze hydraulic head and aquifer temperature data.

3. Graphical tools were developed to easily modify the model inputs and evaluate the model output (Chapter 8).

4. Existing models were integrated to consolidate the existing regional groundwater information.

5. The groundwater model had to be adequately calibrated (Chapter 5). The calibration was conducted to ensure simulated and measured hydraulic head values are close to the same values and simulated average linear velocities and average linear velocities estimated from the hydraulic head measurements near the WAGs are close to the same values.

6. Sensitivity analysis was performed.

7. A WAG 10 data base was developed for all literature pertinent to WAG 10 groundwater modeling.

8. A source of information was established so modelers interested in modeling the regional groundwater flow below the INEL have ready access to the codes developed, input files, and output files generated in this study.

9. This report was written to document the flow model development and calibration and development of associated computational tools. This report will allow future modelers to identify the model's uses, strength, and weaknesses. 


\section{HYDROGEOLOGIC SETTING}

This chapter summarizes what is known about the geology and hydrology of the ESRP and its aquifer. It includes qualitative descriptions of the geology as well as quantitative descriptions of measurements made to define the hydrology.

\subsection{Geology}

\subsubsection{Surface Geology}

On the ESRP (Figure 1-1), the surface is made up of volcanic rocks, alluvial sediments, and windblown sediments. Volcanic rocks are primarily comprised of basalt. The sediments are clay, silt, and sand. Surrounding mountains are comprised of consolidated sedimentary and metamorphic rocks, primarily limestone, sandstone, and quartzite. Whitehead (1986) provides a description of the geohydrologic framework of the ESRP.

\subsubsection{Subsurface Geology}

The subsurface stratigraphy below the INEL contains interlayers of basalt lava flows and sedimentary deposits. Periods of volcanism were separated by longer intervals of sedimentation and resulted in major sedimentary interbeds. Extensive lava flows range from 50 to $100 \mathrm{mi}^{2}$ in area and 20 to $25 \mathrm{ft}$ in thickness. Interbeds range from 0 to more than $50 \mathrm{ft}$ in thickness.

Because of the way they were formed, the tops and bottoms of lava flows contain more fractures than their interiors. The interior of the lava flows can contain some vertical fracturing. The principal horizontal flow in the aquifer is through the interflow zones. There is some vertical flow through the aquifer in lava flow interior vertical fractures.

Garabedian (1992), Spinazola (1994a), and Arnett et al. (1993) contain detailed descriptions of the geologic setting of the ESRP. Garabedian (1992) (Plate 5) and Spinazola (1994a) (Figure 6) show the distribution of predominant rock types at selected depth intervals below the water table. Spinazola (1994a) (Figure 7) and Garabedian (1992) (Plate 2) provide generalized geologic sections of the ESRP.

\subsection{Hydrology}

\subsubsection{Precipitation}

Precipitation on the ESRP ranges from 8 to $10 \mathrm{in.} / \mathrm{yr}$. Within the surrounding basin there are areas that receive precipitation of more than $60 \mathrm{in.} / \mathrm{yr}$.

Figure 2-1 shows contours of the mean annual precipitation from 1930 to 1990 . Figure 2-2. shows the variation in precipitation and the cumulative departure from the mean annual precipitation at Aberdeen and Ashton from 1915 to 1984 . The information shown in Figures 2-1 and 2-2 come from the State Climate Services for Idaho, University of Idaho. Rainfall variations at Ashton are more extreme than at Aberdeen, but exhibit the same wet and dry periods.

Precipitation on the ESRP can vary from relatively dry (e.g., 1930 to 1935 and 1952 to 1962) to relatively wet (e.g., 1936 to 1942 and 1963 to 1976).

\subsubsection{Evaporation}

Water is removed from the ESRP through evaporation from rivers, streams, and lakes and by evapotranspiration. Agricultural evapotranspiration rates vary by crop, temperature, amount of precipitation and irrigation water, and season.

Evapotranspiration rate estimates vary from 20 to $40 \%$ of the water used for irrigation (Garabedian 1992). 
Snake River

-... INEL Boundory

- Domain Boundory

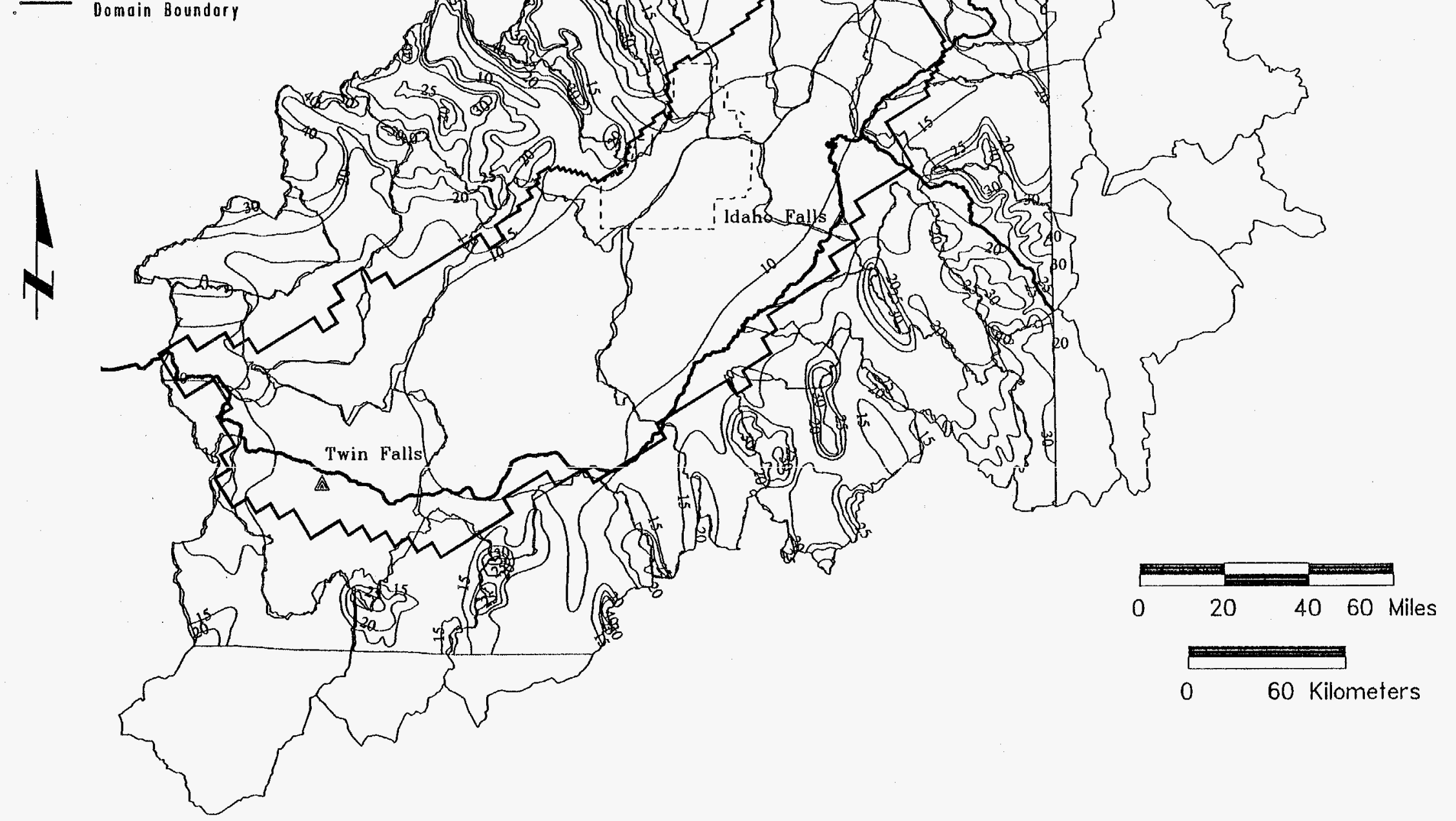

Figure 2-1. Estimated average annual precipitation over the domain over the Snake River drainage basin upstream of King Hill. 

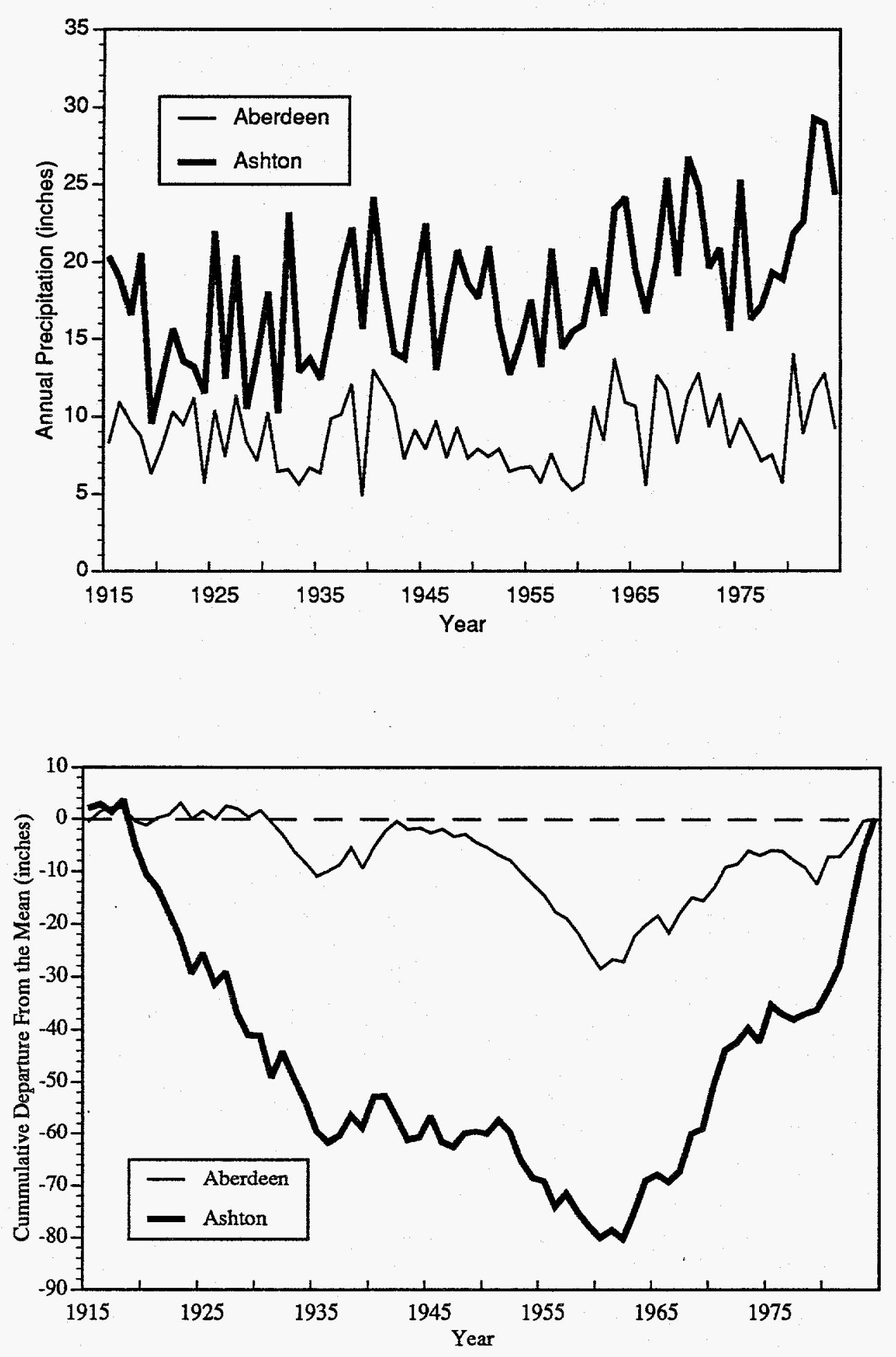

Figure 2-2. Measured long-term precipitation and the cumulative departure from the mean at rain gauges at Aberdeen and Ashton. 


\subsubsection{Surface Water}

Surface water on the ESRP comes from draining rivers and streams, snowmelt, and rain. Rivers and streams that contribute directly to the Snake River flow include the Henry's Fork of the Snake River, Blackfoot River, Portneuf River, Big Wood River, and Salmon Falls Creek. The amount of water supplied to the drainage basin by each tributary depends on the area of the drainage basin (also called the watershed), total precipitation, and consumptive use in the drainage basin. Tributaries on the northwestern edge of the ESRP that contribute water to the plain by infiltration include the Big Lost River, Little Lost River, Birch Creek, Medicine Lodge Creek, Beaver Creek, and Camas Creek. Forty-nine percent of the total tributary drainage basin yield to the ESRP flows onto the plain from the Snake River near Heise (Garabedian 1992). Twenty-three percent of the tributary drainage basin yield is from Henry's Fork, and $10 \%$ is from the northwestern tributaries.

The outline of the ESRP and the ESRP drainage basin are shown in Figure 2-3. The basin has been subdivided into 26 subbasins to estimate the relative contributions each tributary makes to the aquifer water budget.

\subsubsection{Groundwater}

2.2.4.1 Irrigation. Residents of the ESRP obtain water for irrigation by pumping groundwater and diverting surface water. Irrigation from diverted surface water is the largest source of groundwater recharge to the ESRP aquifer. Garabedian (1992) reports that seepage losses from unlined irrigation canals are also a major source of groundwater recharge to the ESRP aquifer.

Several reports document areas irrigated on the ESRP. Garabedian (1992) provides a chronology of the increase in irrigated acreage on the ESRP from 1880 to 1980, and Plate 3 in the report shows irrigated areas in the years 1899, 1929, 1945, 1966, and 1979.

2.2.4.2 Discharge. Starting in 1945, groundwater pumping for irrigation increased significantly (Garabedian 1992). An estimated $2,430 \mathrm{ft}^{3} / \mathrm{sec}$ of groundwater was pumped in 1980 to irrigate 930,000 acres. Nonirrigation uses of pumped groundwater total about $5 \%$ of the irrigation withdrawals. Figure 2-4 shows the distribution of groundwater pumping in 1980 (Garabedian 1992 and Spinazola 1994a).

In addition to pumping irrigation water, seeps and springs discharge groundwater from the ESRP aquifer to the Snake River between Blackfoot to Neeley and from Milner to King Hill. Major springs and seeps discharge along the Snake and Portneuf Rivers north and east of American Falls Reservoir.

Groundwater discharge from the north side of the Snake River from Milner to King Hill increased after 1911 because of increased surface water irrigation in Gooding, Jerome, and Lincoln Counties (Garabedian 1992, Figure 11). Spring flow in this area increased until the 1950 s and has declined since.

Generally, spring discharges are lowest before irrigation begins and highest just after irrigation ends. Since 1912, the mean annual groundwater discharge between Blackfoot and Neeley has been relatively constant (Garabedian 1992, Figure 12).

2.2.4.3 Recharge. Groundwater is recharged from stream and canal losses, seepage from surface water diverted for irrigation, underflow from the tributary drainage basins, and precipitation. The greatest sources of recharge are the surface water from the Snake River that is diverted for irrigation in excess of consumptive use and recharge on the margin of the plain from tributary underflows. Seepage from rivers, lakes, streams, and canals also accounts for a significant amount of recharge. 


\section{LEGEND}

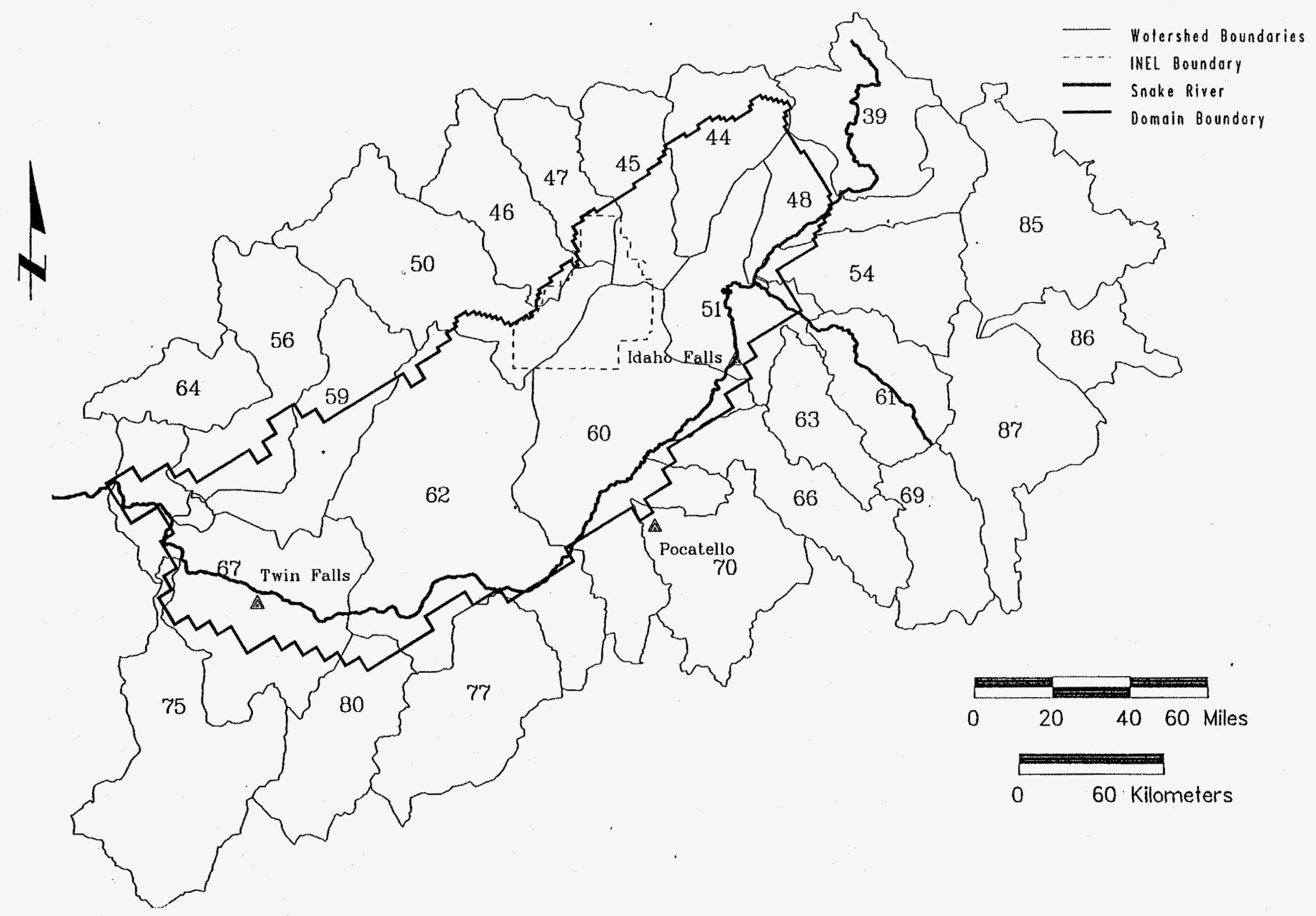

Figure 2-3. Tributary basins and surface water features. 


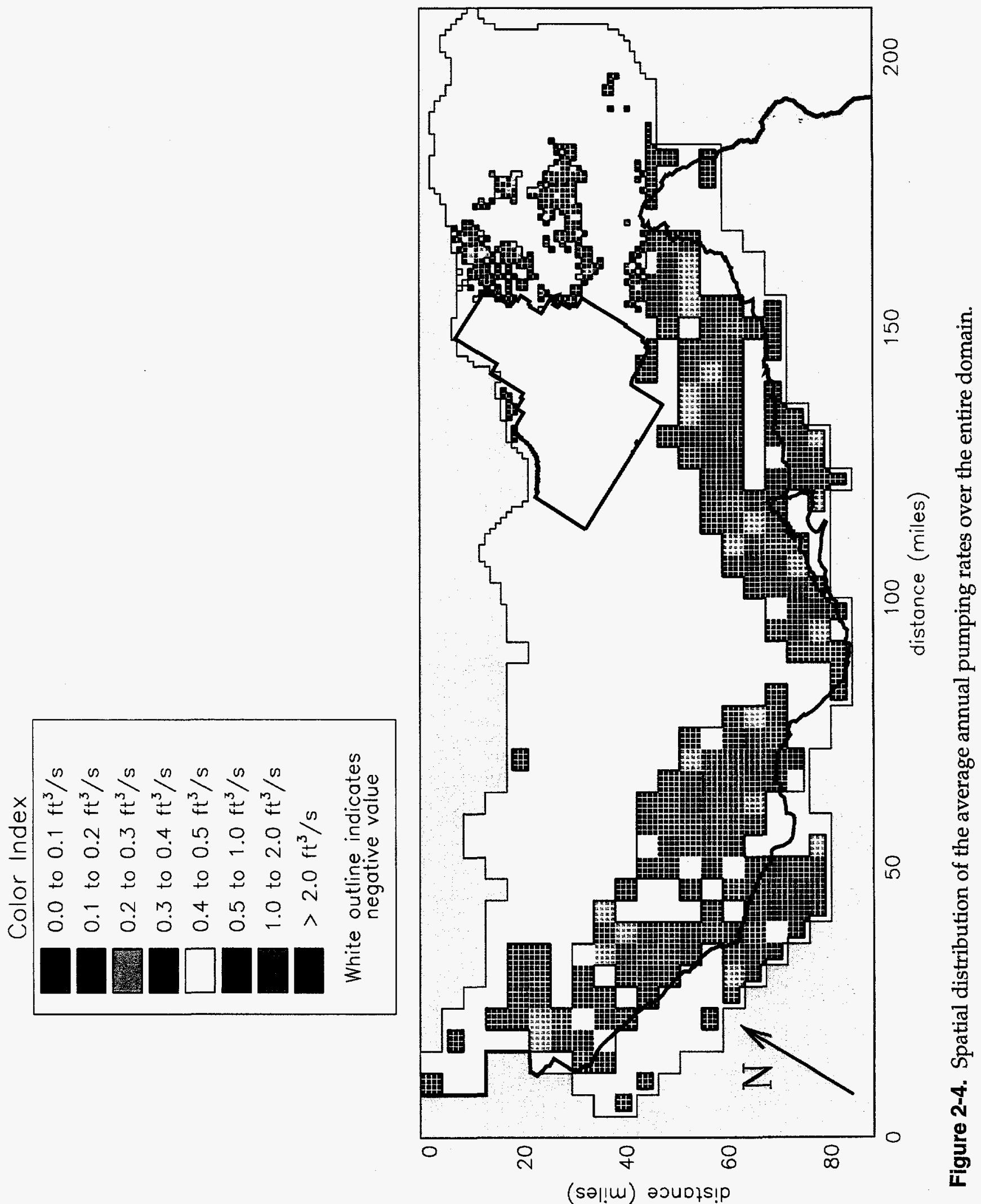
Because precipitation on the ESRP is minimal, it provides only 1 in. of annual rainfall as recharge (Kjelstom 1986). However, larger amounts of precipitation falling in the mountains reach the ESRP aquifer.

The conceptual model chapter of this report contains quantitative estimates of the contribution each source of recharge makes to the water budget.

2.2.4.4 Active Aquifer Depth. The active aquifer depth is the depth below which there is very little water movement. An accurate active depth of the ESRP aquifer at various locations is not known; however, the depth is estimated to range from $200 \mathrm{ft}$ near the margin of the plain to greater than $3,000 \mathrm{ft}$ in the center of the aquifer (Garabedian 1992, Plate 5).

Current studies are being used to identify an accurate active aquifer depth. Steve Anderson of the USGS is evaluating the stratigraphy of the ESRP aquifer to estimate the active aquifer depth as a function of space. Researches at the INEL are using aquifer temperature studies to infer the depth at which water is moving horizontally in wells. These studies indicate that the active aquifer depth varies dramatically by location.

\subsubsection{Regional Groundwater Flow.} Generally, groundwater flows in the ESRP aquifer from the mountains in the northeast to discharge in the southwest. While the aquifer is generally unconfined at the top, layers of lower permeability sediments and basalt create confined conditions in the aquifer.

Groundwater levels in irrigated areas fluctuate in response to seasonal and shortand long-term climatic trends (Garabedian 1992). Water levels are usually the highest from October through March and lowest in July or August.
The flow of water from the Big Lost River into the Spreading Areas to the south of the INEL Site and subsequent infiltration has resulted in water level fluctuations and flow direction shifts in the aquifer. The impact of infiltration from the Big Lost River on the aquifer is important at the INEL because several WAGs are located close to the Big Lost River or the spreading areas.

Hydraulic gradients vary from very steep $(>100 \mathrm{ft} / \mathrm{mi}$ ) on the margins of the plain to very small (as little as $3 \mathrm{ft} / \mathrm{mi}$ ) in the middle of the plain. Vertical water movement in the aquifer has been documented in some areas of the plain, but very few piezometers are currently available to evaluate this phenomena, particularly within the INEL Site. Vertical movement of water in the aquifer is discussed in McCarthy et al. (1994), Arnett et al. (1993), Garabedian (1992), and Spinazola (1994a).

\subsubsection{Transmissivity and Hydraulic} Conductivity. Transmissivity (T) and hydraulic conductivity (K) values represent the ability of a geologic formation to conduct water. Because of the interlayering of basalt lava flows and sedimentary deposits and the variable nature of the lava flow, $T$ and $K$ values are extremely variable in the ESRP aquifer.

Transmissivity and $\mathrm{K}$ values are highly dependent on the amount and distribution of gravel, sand, silt, and clay in the geologic formation as well as the frequency and inner connectivity of fractures within the basalt flows. Dense basalt centers have very low hydraulic conductivities, and interflow zones containing rubble, clinkers, and cinders have very high hydraulic conductivities. For example, $K$ values of basalt can range from $10^{-7}$ to $10^{-1} \mathrm{ft} / \mathrm{sec}$, and $\mathrm{K}$ values of clay and silt can range from $1.3 \times 10^{-7}$ to $13 \mathrm{ft} /$ day (Freeze and Cherry 1979). 
Several studies have been performed to determine the $T$ and $K$ values in the area of the ESRP. Ackerman (1991) presents the results of analyzing 183 single well tests at 94 wells in the ESRP aquifer on and in the vicinity of the INEL. The $T$ values ranged from $1.3 \times 10^{-5}$ to $8.8 \mathrm{ft}^{2} / \mathrm{sec}$. These values represent $\mathrm{T}$ near the test wells and within the test intervals.

Because the aquifer is highly heterogeneous and the thickness is unknown, these local measurements cannot be directly used for modeling. However, the values are useful for establishing a range of $T$ values. Table 2-1 shows the distribution of $T$ values reported by Ackerman.
Garabedian (1992) summaries the $T$ and storage coefficient data from 31 aquifer tests. The tests indicate that in the upper 100 to $200 \mathrm{ft}$ of the aquifer the $\mathrm{T}$ ranged from 1.0 to $56 \mathrm{ft}^{2} / \mathrm{sec}$.

Spinazola (1994a) (see Figures 33, 34, and 35) estimated $T$ and $K$ values from specific capacity tests upgradient of the INEL. The median estimated $\mathrm{K}$ for wells completed in basalt was $1.4 \times 10^{-2} \mathrm{ft} / \mathrm{sec}$, and the maximum was $1.7 \times 10^{-1} \mathrm{ft} / \mathrm{sec}$. The median $\mathrm{K}$ estimated for wells completed in sediment was $9.0 \times 10^{-3}$ $\mathrm{ft} / \mathrm{sec}$, and the maximum was $3.5 \times 10^{-2} \mathrm{ft} / \mathrm{sec}$. Median K estimated for wells completed in both basalt and sediment was $1.7 \times 10^{-2} \mathrm{ft} / \mathrm{sec}$, and the maximum was $1.4 \times 10^{-1} \mathrm{ft} / \mathrm{sec}$. 
Table 2-1. Distribution of estimated transmissivity at and near the Idaho National Engineering Laboratory (Ackerman 1991)

\begin{tabular}{ccccc}
\hline $\begin{array}{c}\text { Class } \\
\text { interval }\end{array}$ & Frequency & $\begin{array}{c}\text { Center of interval } \\
\left(\times 10^{-5} \mathrm{ft}^{2} / \mathrm{sec}\right)\end{array}$ & $\begin{array}{c}\text { Extremes of lower } \\
\text { interval } \\
\left(\times 10^{-5} \mathrm{ft}^{2} / \mathrm{sec}\right)\end{array}$ & $\begin{array}{c}\text { Extremes of upper } \\
\text { interval } \\
\left(\times 10^{-5} \mathrm{ft}^{2} / \mathrm{sec}\right)\end{array}$ \\
\hline 1 & 2 & 2.3 & 1.3 & 4.2 \\
2 & 1 & 6.9 & 4.2 & 13 \\
3 & 6 & 23 & 13 & 42 \\
4 & 1 & 69 & 42 & 130 \\
5 & 6 & 230 & 130 & 420 \\
6 & 7 & 690 & 420 & 1,300 \\
7 & 6 & 2,300 & 1,300 & 4,200 \\
8 & 7 & 6,900 & 4,200 & 13,000 \\
9 & 16 & 23,000 & 13,000 & 42,000 \\
10 & 19 & 69,000 & 42,000 & 130,000 \\
11 & 16 & 230,000 & 130,000 & 420,000 \\
12 & 7 & 690,000 & 420,000 & $1,300,000$ \\
\hline & & & &
\end{tabular}





\section{CONCEPTUAL MODEL}

A groundwater flow conceptual model is a simplified description of an aquifer and the physical processes believed to govern groundwater flow through the aquifer. The objectives of the model and knowledge of the system determine the appropriate level of simplification. Because the ESRP aquifer is extremely complex and our understanding of the detailed physical processes that govern flow is limited, the conceptual model representing the processes that occur in the aquifer must be simplified.

A primary objective of this study was to develop tools to support future contaminant transport modeling in the ESRP aquifer in the area of the INEL. The primary parameter needed to predict contaminant transport is the average linear velocity of water in the aquifer. To accurately predict the average linear velocity, the flow model must include an accurate water budget. To define an accurate water budget, the domain must extend to boundaries where hydrologic conditions can be accurately estimated.

This groundwater flow conceptual model was developed by defining (1) the model area of interest (model domain), (2) the water gains and losses (water budget), and (3) the flow system (aquifer properties).

This conceptual model integrates a number of models previously developed and explained in detail in other reports. Therefore, this chapter summarizes the essential components of the conceptual model and references other sources of information for additional detail.

\subsection{Model Domain}

The current model domain, or model area of interest, is the boundary of the ESRP as defined in Garabedian (1992) (Plate 1) and shown in Figure 1-1. The INEL overlays
$900 \mathrm{mi}^{2}$ of the $10,800 \mathrm{mi}^{2}$ total domain area. Using information from Garabedian (1992) (Plate 5), aquifer thickness is assumed to range from 500 to $4,000 \mathrm{ft}$.

The flow system used in the current model is comprised of four aquifer layers. The upper two layers are of constant thickness, and the lower two layers are of variable thickness. Flow is assumed to move horizontally in each aquifer layer, and water moves from one layer to another through a simple Darcian leakage term. This approach, referred to as pseudo three dimensional, simulates flow through the active depth of the aquifer without developing a true three- dimensional model.

The four-layer system is based on the model presented in Garabedian (1992). Spinazola (1994a) divided the upper layer into two layers, creating a five-layer model. The current model combines the upper two layers of Spinazola's model to integrate it with the Garabedian model. Table 3-1 compares the aquifer layer thicknesses used in Garabedian (1992) and this current model and Spinazola (1994a). Figures 3-1 and 3-2 show the assumed aquifer thickness for variable thickness layers 3 and 4 , respectively.

Table 3-1. Layer depths used in Garabedian (1992) and Spinazola (1994a) models.

\begin{tabular}{ccc}
\hline Layer & $\begin{array}{c}\text { Garabedian } \\
\text { and current } \\
\text { model layer } \\
\text { depth } \\
(\mathrm{ft})\end{array}$ & $\begin{array}{c}\text { Spinazola } \\
\text { model layer } \\
\text { depth } \\
(\mathrm{ft})\end{array}$ \\
\hline 1 & 200 & 100 \\
2 & 300 & 100 \\
3 & $0-500$ & 300 \\
4 & $0-3,000$ & $0-500$ \\
5 & - & $0-1,000$ \\
\hline
\end{tabular}




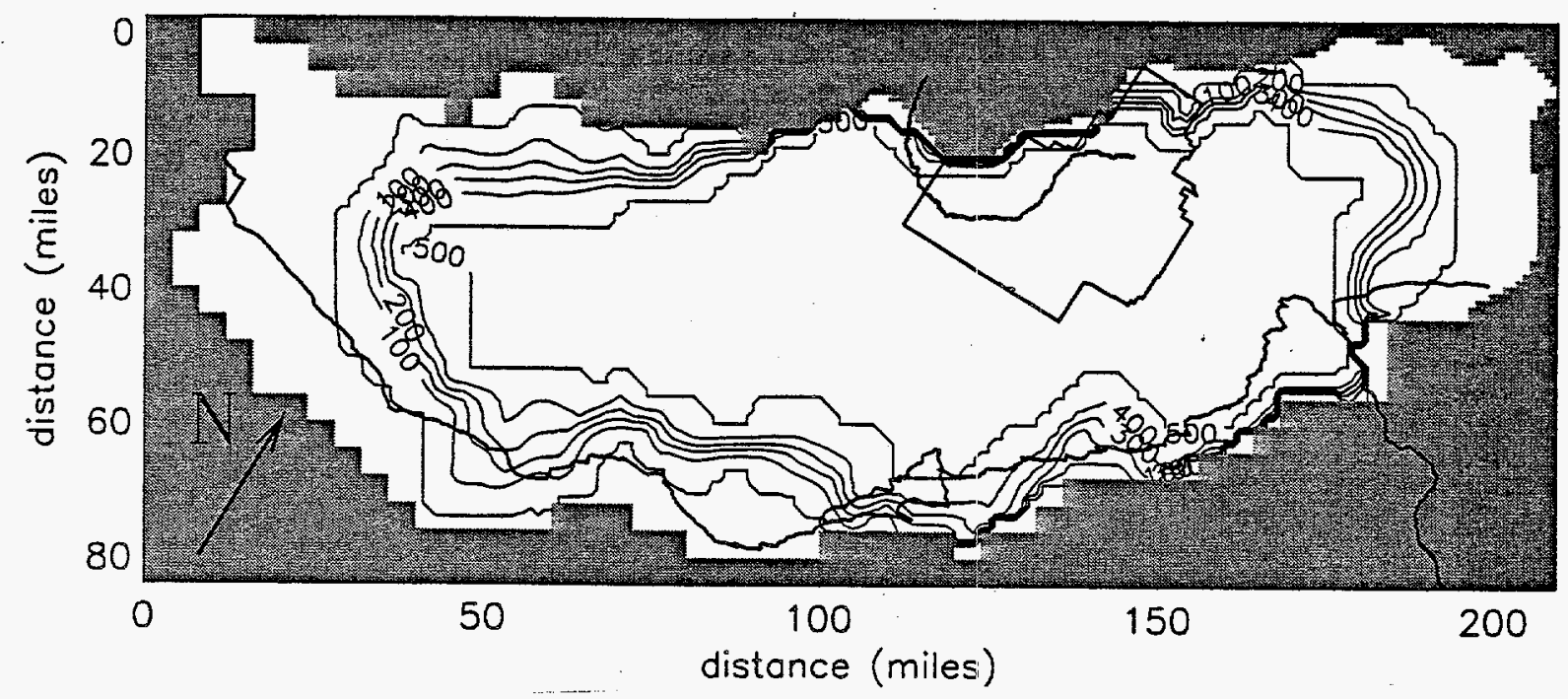

Figure 3-1. Contour map of the aquifer thickness in layer 3.

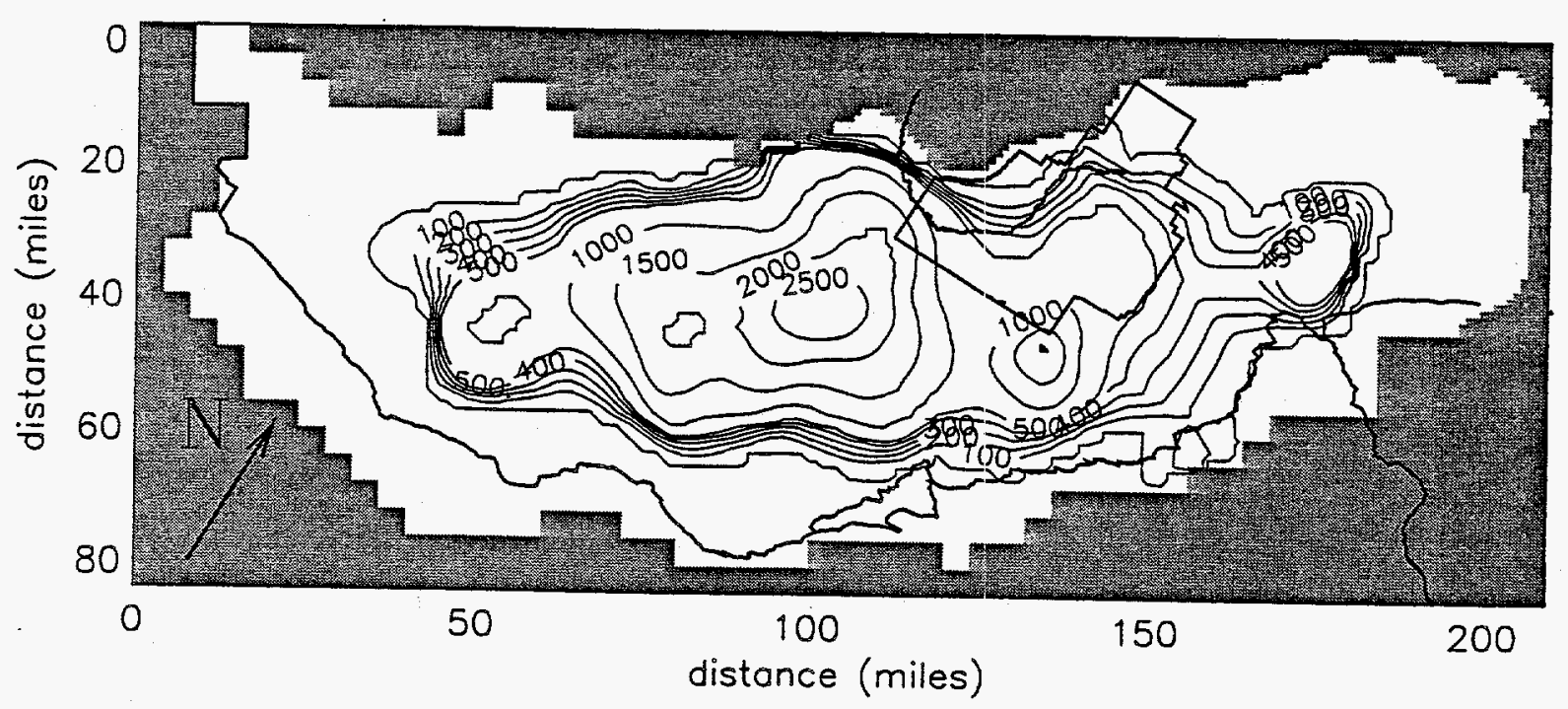

Figure 3-2. Contour map of the aquifer thickness in layer 4. 


\subsection{Water Budget-}

The foundation of a groundwater conceptual model is an accurate water budget. Water budget values presented in Garabedian (1992) and Spinazola (1994a) were assumed to be accurate and were used in this model. Components of the groundwater budget incorporated in this model include (a) aquifer gains from and losses to the Snake River, (b) streams, canals, lakes, and ponds losses to the aquifer, (c) irrigation from surface water and groundwater, (d) precipitation, and (e) underflow from tributary drainage basins.

A 1980 water budget is used for the pseudo steady-state model. Water year 1980 was chosen to represent steady-state conditions based on the analysis of Garabedian (1989). Garabedian's analysis found that the 1980, and the 1950-1980 water year fluxes were similar to the average annual flux for the period 1950-1980 and the 1950-1980 hydrologic conditions were relatively stable compared to 1880-1950. Irrigation diversions and groundwater levels were relatively stable from 1950-1980, implying that the water flux into and out of the aquifer were similar (steady-state conditions).

The transient model focuses on the transient impact of the Big Lost River, Little Lost River, and Birch Creek. The following major assumptions are used for the transient model: (a) gains and losses observed in the Snake River for 1980 are constant from 1980 to 1990, (b) Spinazola's average water budget values for 1980 to 1990 are adequate, (c) transient recharge from the Big Lost River, Little Lost River, and Birch Creek influence the flow regime of the INEL, and (d) yearly variations in the water budget are modeled; seasonal variations are ignored except in areas very close to INEL facilities.
Spinazola (1994a) provides transient water budget information for the years 1980 to 1990 including monthly estimates of the following transient water budget components:

- Streamflow at selected gauging stations

- Groundwater inflow to Mud Lake, Mud Lake Wildlife Management Area, and Camas National Wildlife Refuge

- Irrigation diversions

- Lake evaporation

- Stream and lake losses and gains to the aquifer

- Recharge from precipitation and irrigation

- Groundwater withdrawals

- Discharge from flowing wells.

Spinazola does not present the results of a transient model; therefore, these water budget component data were used directly in the current flow model to supplement the transient portion.

\subsubsection{Snake River}

The current model uses estimates of Snake River water gains and losses reported in Garabedian (1992) and originally published in Kjelstrom (1986). The Snake River reaches for which gains and losses are defined are shown in Figure 3-3, and the numerical values are shown in Table 3-2. Figure 3-4 shows the transient gains and losses to the Snake River reaches before 1980 .

In $1980,70 \%$ of gauged flow at King Hill was discharged from springs along the reach from Milner to King Hill (Kjelstrom 1986). 


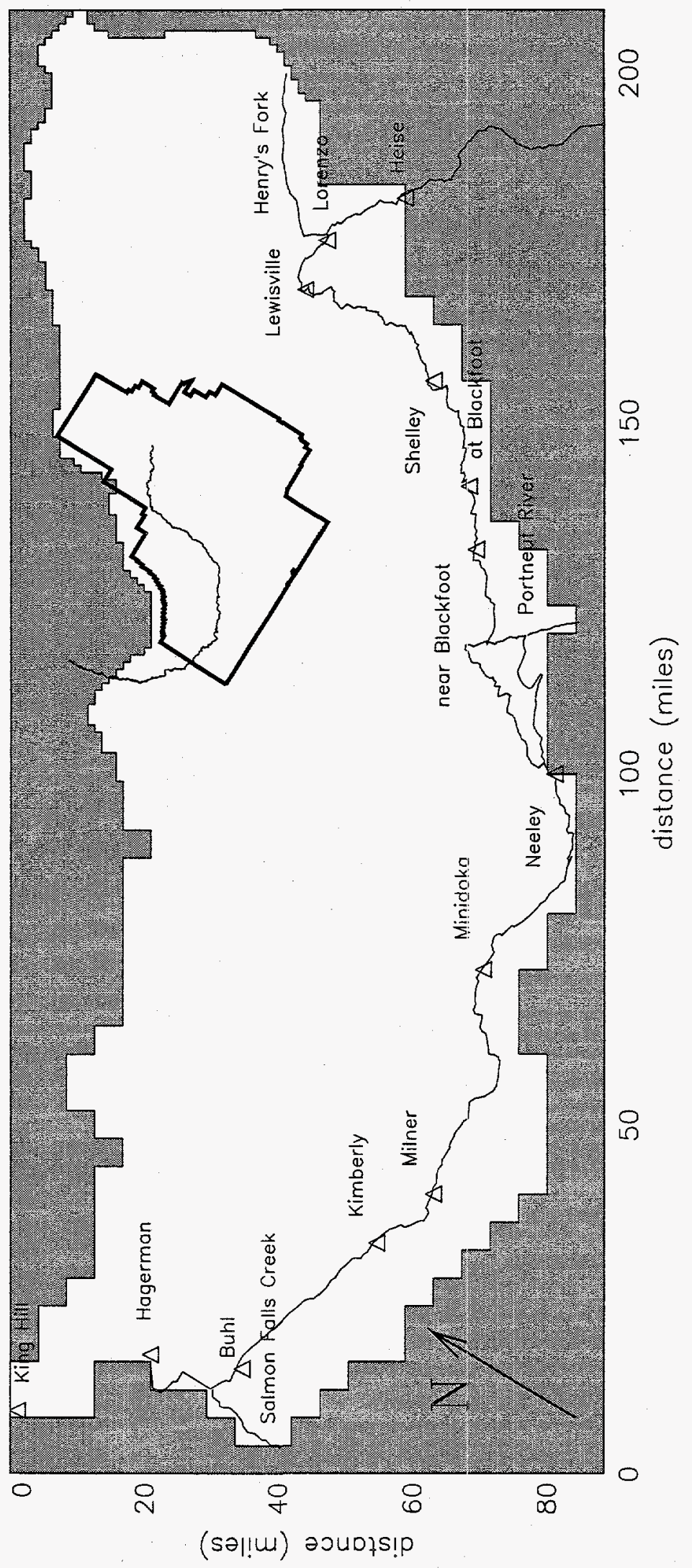

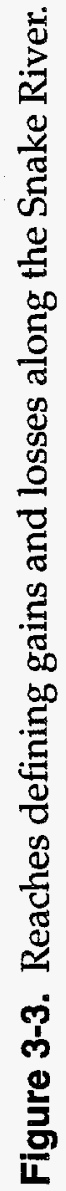


Table 3-2. Snake River losses to and gains from the aquifer, water year 1980 (Garabedian 1992, Table 8).

\begin{tabular}{lc}
\hline \multicolumn{1}{c}{$\begin{array}{c}\text { Reach } \\
\text { (gauging-station locations shown on Plate 1) }\end{array}$} & $\begin{array}{c}\text { Loss }(-) \text { or gain } \\
\left(\mathrm{ft}^{3} / \mathrm{sec}\right)\end{array}$ \\
\hline Heise to Lorenzo & -145 \\
Lorenzo to Lewisville & 289 \\
Lewisville to Shelley & -379 \\
Shelley to at Blackfoot & -153 \\
At Blackfoot to near Blackfoot & -270 \\
Near Blackfoot to Neeley & 2,620 \\
Neeley to Minidoka & 179 \\
Minidoka to Milner & 132 \\
Milner to Kimberly (north side) & 30 \\
Milner to Kimberly (south side) & 266 \\
Kimberly to Buhl (north side) & 1,112 \\
Kimberly to Buhl (south side) & 110 \\
Buhl to Hagerman (north side) & 3,456 \\
Buhl to Hagerman (south side) & 150 \\
Hagerman to King Hill & 1,412 \\
Total loss & \\
Total gain & -947 \\
\hline
\end{tabular}




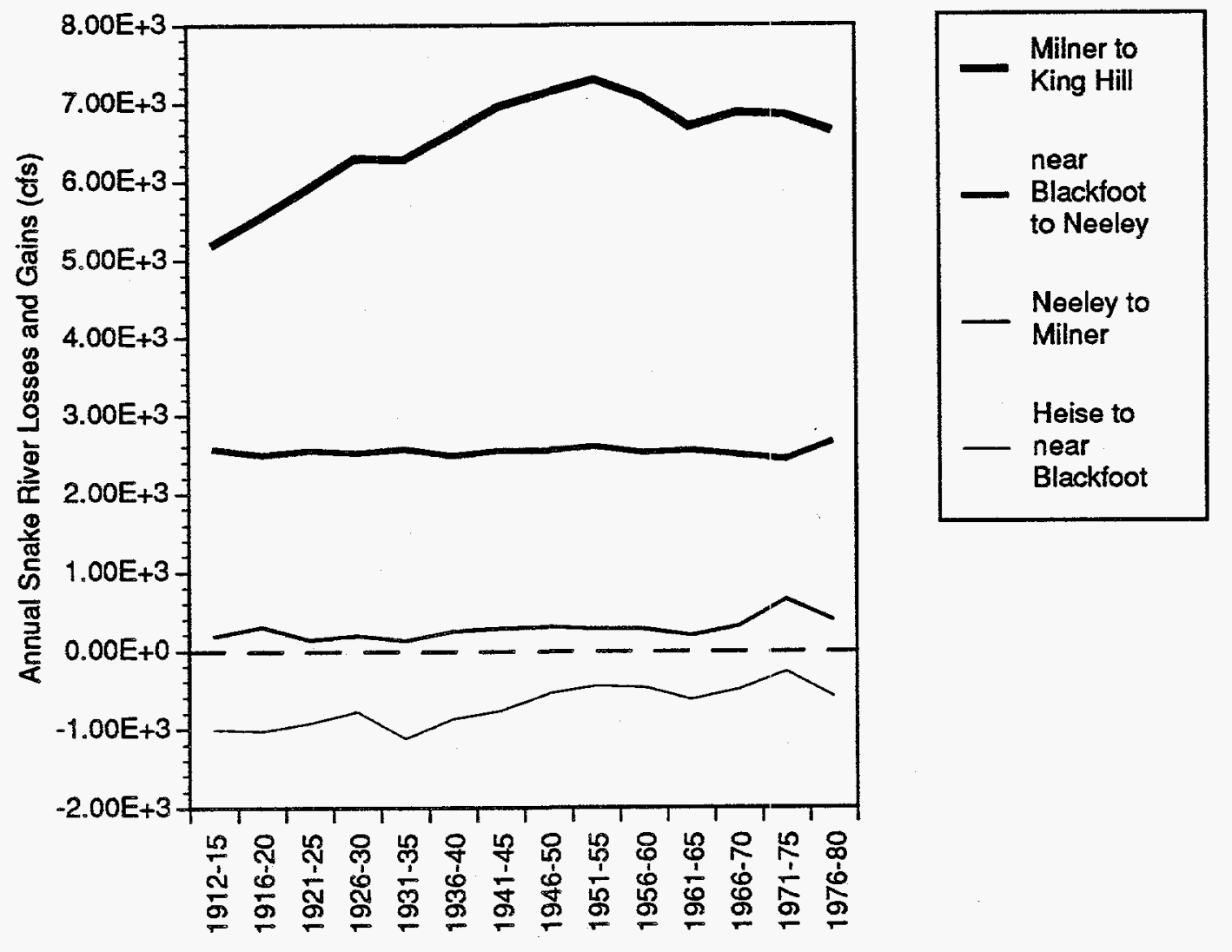

Figure 3-4. Snake River losses to (-) and gains from (+) groundwater, 1912-1980. 
Snake River elevations for the current model were estimated from gauging station information and Garabedian's RIVER file. The river elevation was assumed to vary linearly between gauging stations. The river bed conductance defines the capability of the riverbed material to conduct water between the river and the aquifer. The river conductances presented in Garabedian (1992) were assumed to be adequate for this model, and the conductances were not used as a model calibration parameter. Table 3-3 shows the estimated Snake River elevations at different gauging stations. The river conductances are described in Section 4.1.3.

\subsubsection{Streams, Canals, Lakes, and Ponds}

Stream and canal water losses are estimated to be to $562 \mathrm{ft}^{3}$ / sec annually (Garabedian 1992 and Spinazola 1994a), which is a significant portion of the groundwater budget. Figure 3-5 shows the major streams and canals in the domain that contribute to these losses. Table 34 summarizes the 1980 annual losses from the streams and canals.

This model refines the estimated losses from the Big Lost and Little Lost Rivers to improve the accuracy of the transient modeling in the vicinity of the INEL. This conceptual model incorporates Spinazola's modification of the losses from the Camas, Medicine Lodge, and Beaver Creeks where he incorporated the surface and subsurface interaction explicitly into his model.

\subsubsection{Recharge from the Big Lost}

River. Because of the proximity of the Big Lost River and the associated spreading areas to INEL facilities, a detailed analysis was conducted of spatial and temporal losses from infiltration. Data on flow rates in the Big Lost River at various gauging stations were available from Bennett (1990) and USGS river discharge data. Figure 3-6 shows the location of the major gauging stations and the locations of the model boundary. Table 3-5 summarizes average flow data at each station, including beginning and ending year and number of months of data obtained from 1980 through 1990. Losses were calculated by subtracting the flow rate at each station from the flow rate at the next upstream station. There was 1 year of data from a station just above the INEL diversion. This short time period was insufficient to estimate the average flow rate between 1980 and 1990. The total flow in the Big Lost River at the INEL diversion was calculated to be the sum of the flow below the diversion and the flow diverted to the spreading areas. This sum was used to calculate the average losses between the Near Arco and INEL diversion stations.

The loss in river flow between consecutive stations was assumed to be from infiltration (a calculation showed that evapotranspiration was a few percent of the losses). The loss (infiltration) was also assumed to be distributed uniformly between consecutive stations. While uniform loss is unlikely, insufficient data exist to estimate a nonuniform rate. With one exception, it was believed that such detail was not required for the current model. There was a large average loss between Mackay Reservoir and the Near Arco station (see Table 3-5). Most of these losses are believed to occur before reaching the current model boundary (see Figure 3-6) and are accounted for as underflow to the model. The loss rate from the current model boundary to the Near Arco station was assumed to be the same rate per unit distance as the rate between the Near Arco station and the INEL diversion. The flow measured at the outlet of Spreading Area A was assumed to be evenly distributed over Spreading Areas B through D. Flow below Playa 1 was uniformly distributed along the portion of the Big Lost River below that point (see Figure 3-6). 
Table 3-3. Snake River water elevation and leakage cutoff below the river used at and between gauging stations.

\begin{tabular}{|c|c|c|c|c|}
\hline \multirow[b]{2}{*}{$\begin{array}{c}\text { Starting } \\
(\mathrm{ft})\end{array}$} & \multirow[b]{2}{*}{$\begin{array}{l}\text { Ending } \\
(\mathrm{ft})\end{array}$} & \multirow{2}{*}{$\begin{array}{c}\text { Leakage } \\
\text { cutoff } \\
\text { below river } \\
\text { (ft) }\end{array}$} & \multicolumn{2}{|r|}{ Reach } \\
\hline & & & Number & Name \\
\hline 3,050 & 2,600 & 0 & 1 & Snake, Hagerman to King Hill \\
\hline 3,056 & 3,050 & 0 & 2 & Snake, Buhl to Hagerman \\
\hline 3,614 & 3,056 & 0 & 3 & Snake, Kimberly to Buhl \\
\hline 4,009 & 3,614 & 0 & 4 & Snake, Milner to Kimberly \\
\hline 4,240 & 4,009 & -30 & 5 & Snake, Minidoka to Milner \\
\hline 4,247 & 4,240 & -30 & 6 & Snake, Neeley to Minidoka \\
\hline 4,430 & 4,247 & -30 & 7 & Snake, near Blackfoot to Neeley \\
\hline 4,394 & 4,346 & -30 & 7 & Portneuf, Pocatello to mouth \\
\hline 4,504 & 4,430 & -30 & 8 & Snake, At Blackfoot to near Blackfoot \\
\hline 4,599 & 4,504 & -30 & 9 & Snake, Shelley to At Blackfoot \\
\hline 4,784 & 4,599 & -30 & 10 & Snake, Lewisville to Shelley \\
\hline 4,823 & 4,784 & -30 & 11 & Snake, Lorenzo to Lewisville \\
\hline 4,962 & 4,823 & -30 & 12 & Snake, Heise to Lorenzo \\
\hline 4,988 & 4,824 & -30 & 13 & Henry's Fork, Ashton to mouth \\
\hline 3,400 & 3,200 & 0 & 14 & Salmon Falls \\
\hline
\end{tabular}




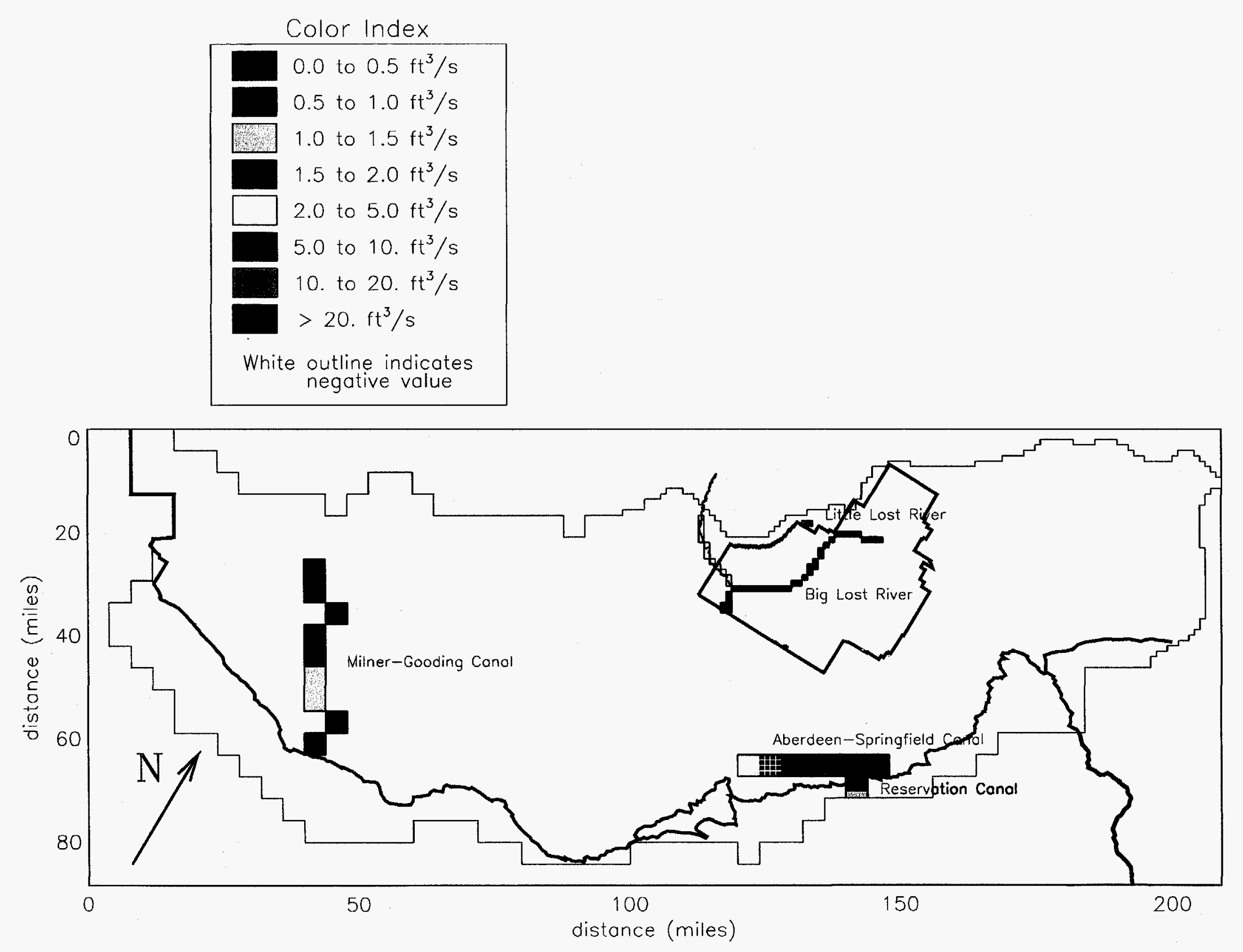

Figure 3-5. Reaches defining losses along the Big Lost and Little Lost Rivers and Reservation, Aberdeen Springfield, and Milner-Gooding Canals. 
Table 3-4. Average annual tributary-stream and canal losses to the groundwater system.

\begin{tabular}{|c|c|}
\hline Name & $\begin{array}{c}\text { Loss } \\
\left(\mathrm{ft}^{3} / \mathrm{sec}\right)\end{array}$ \\
\hline Big Lost River & 162 \\
\hline Little Lost River & 19 \\
\hline Camas, Beaver, and Medicine Lodge Creeks & 151 \\
\hline Milner-Gooding Canal & 112 \\
\hline Aberdeen-Springfield Canal & 101 \\
\hline Reservation Canal & 17 \\
\hline Total & 562 \\
\hline
\end{tabular}




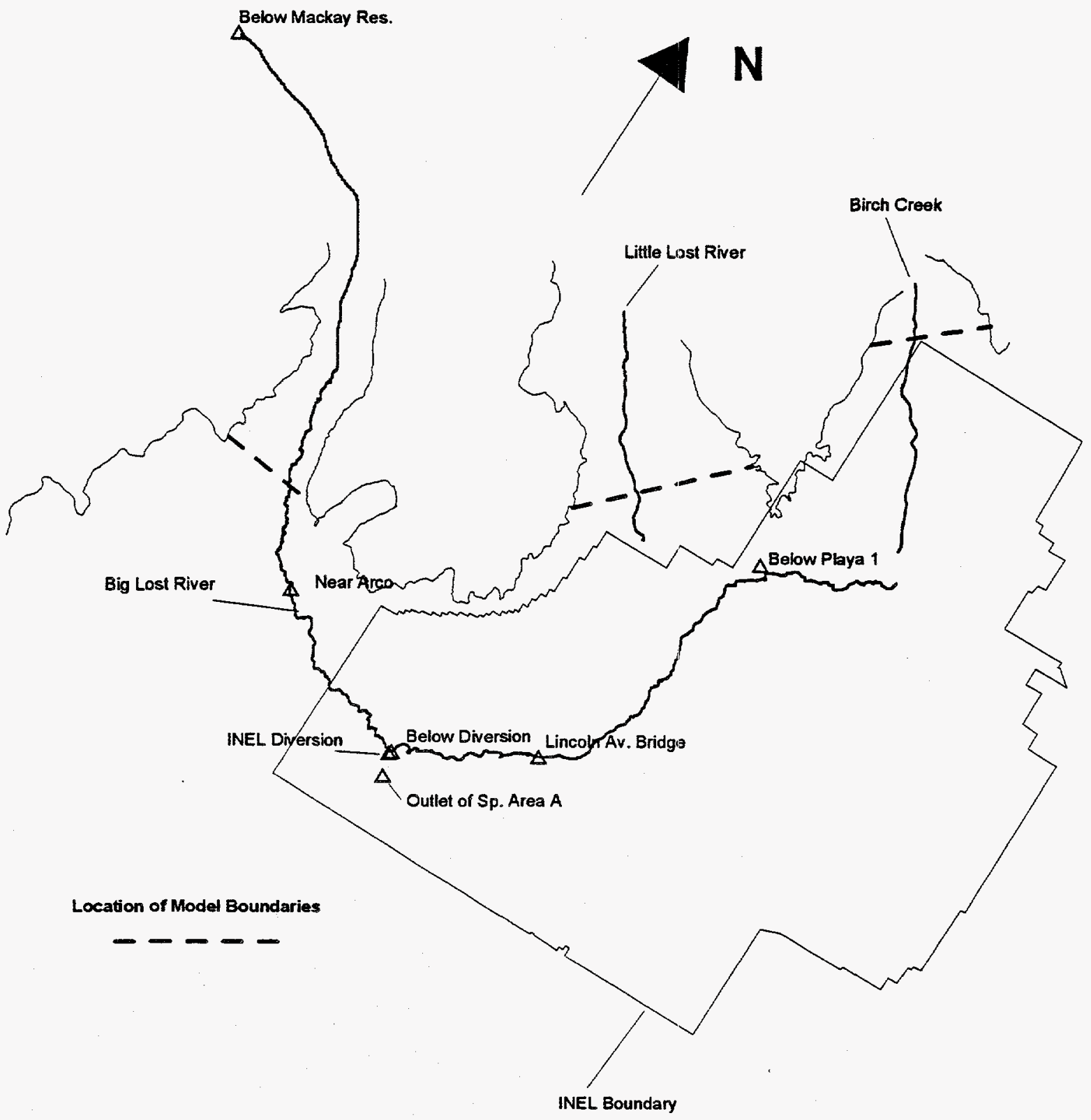

Figure 3-6. Model underflow boundaries and location of major gauging stations along the Big Lost River, Little Lost River, and Birch Creek. 
Table 3-5. Losses in reaches along the Big Lost River.

\begin{tabular}{|c|c|c|c|c|c|c|c|}
\hline \multirow[b]{2}{*}{ Station } & \multirow[b]{2}{*}{$\begin{array}{l}\text { Begin } \\
\text { year }\end{array}$} & \multirow[b]{2}{*}{$\begin{array}{c}\text { Ending } \\
\text { year }\end{array}$} & \multirow[b]{2}{*}{$\begin{array}{c}\text { Months } \\
\text { of data }\end{array}$} & \multicolumn{2}{|c|}{$\begin{array}{l}\text { Average flow } \\
\left(\mathrm{ft}^{3} / \mathrm{sec}\right)\end{array}$} & \multicolumn{2}{|c|}{$\begin{array}{c}\text { Average loss } \\
\left(\mathrm{ft}^{3} / \mathrm{sec}\right)\end{array}$} \\
\hline & & & & $\begin{array}{l}\text { Main } \\
\text { river } \\
\text { channel }\end{array}$ & Diverted & $\begin{array}{c}\text { Main } \\
\text { river } \\
\text { channel }\end{array}$ & Diverted \\
\hline \multirow{2}{*}{$\begin{array}{l}\text { Mackay } \\
\text { Reservoir }\end{array}$} & 1980 & 1990 & 132 & 362 & & & \\
\hline & & & & & & 202 & \\
\hline \multirow[t]{2}{*}{ Near Arco } & 1980 & 1990 & 120 & 160 & & & \\
\hline & & & & & & 32 & \\
\hline $\begin{array}{l}\text { Sum above } \\
\text { diversion }\end{array}$ & 1980 & 1990 & & 128 & & & \\
\hline \multirow[t]{2}{*}{ Diversion } & 1980 & 1990 & 129 & & 74 & & \\
\hline & & & & & & & 41 \\
\hline \multirow{2}{*}{$\begin{array}{l}\text { Outlet to } \\
\text { Spreading } \\
\text { Area A }\end{array}$} & 1984 & 1990 & 75 & & 33 & & \\
\hline & & & & & & & 33 \\
\hline \multirow{2}{*}{$\begin{array}{l}\text { Below } \\
\text { diversion } \\
\text { (not } \\
\text { diverted) }\end{array}$} & 1980 & 1990 & 129 & 54 & & & \\
\hline & & & & & & 9 & \\
\hline \multirow{2}{*}{$\begin{array}{l}\text { Lincoln } \\
\text { Bridge }\end{array}$} & 1980 & 1990 & 129 & 45 & & & \\
\hline & & & . & & & 42.7 & \\
\hline \multirow{2}{*}{$\begin{array}{l}\text { Below } \\
\text { Playa } 1\end{array}$} & 1985 & 1990 & 46 & 2.3 & & & \\
\hline & & & & & & 2.3 & \\
\hline
\end{tabular}


flow. The small volume of surface water in the Little Lost River that reaches the model domain infiltrates within a short distance.

\subsubsection{Recharge from Birch Creek.} Most of the drainage from Birch Creek also reaches the aquifer via groundwater underflow. The Birch Creek channel extends a considerable distance onto the ESRP, terminating near the Test Area North at the INEL. However, flow in this channel during 1980 through 1990 was very low. Most of the surface flow originating in Birch Creek was diverted before reaching the INEL boundaries.

\subsubsection{Ponds at the INEL. Regional} modeling ignores infiltration from ponds at the INEL because the water being discharged to the ponds is pumped from the aquifer and returns to the aquifer from the ponds. Pond evaporation is assumed to be negligible.

\subsubsection{Irrigation}

Recharge from surface water diverted for irrigation is the largest contributor to the ESRP aquifer water budget. The current model uses surface water recharge values provided in Garabedian (1992) and Spinazola (1994a). Refer to these reports for details of the methodology used to define the recharge from irrigation.

Recharge from surface water irrigation in excess of consumptive use was estimated by Garbedian to be $6,681 \mathrm{ft}^{3} / \mathrm{sec}$ in 1980 . Figure 3-7 shows the distribution of recharge throughout the model domain, which is primarily recharge from surface water diverted for irrigation. However, the recharge values are composites of recharge from precipitation and surface water irrigation and discharge from evapotranspiration. The information available from the Garabedian model does not separate these water budget components.

\subsubsection{Precipitation}

Precipitation over an area of $35,800 \mathrm{mi}^{2}$, the drainage basin area upstream from King Hill, contributes to the water budget of the ESRP aquifer. Direct recharge from precipitation is estimated in Garabedian (1992) and presented in Figure 9 of his report. Garabedian does not provide separate numerical values for precipitation. The recharge input file combines the precipitation values and recharge from irrigation. Infiltration estimates are based on annual precipitation, soil thickness, and infiltration capacity of the soil cover.

Except for the northeastern portion of the aquifer, the areal distribution of recharge from precipitation distribution is fairly uniform. Recharge from precipitation ranges from $0.5 \mathrm{in}$. $/ \mathrm{yr}$ in the INEL area to more than 6 in. $y r$ in the northeast part of the aquifer. Direct precipitation was estimated by Garbedian to contribute $966 \mathrm{ft}^{3} / \mathrm{sec}$ average recharge rate to the aquifer annually, while surface water irrigation contributes $6,681 \mathrm{ft}^{3} /$ sec over a much smaller area. Because the recharge from precipitation is small and uniformly distributed, it has less influence on the simulated hydraulic head throughout the domain than irrigation recharge from surface water.

Spinazola's estimates of recharge from irrigation and precipitation are slightly different than Garabedian's. The current model used the Spinazola estimates for the northeastern portions of the aquifer. Therefore, the recharge rate because of both irrigation and precipitation was $7,647 \mathrm{ft}^{3} / \mathrm{sec}$ for the Garabedian model and 7,349 $\mathrm{ft}^{3} / \mathrm{sec}$ for the current model. 


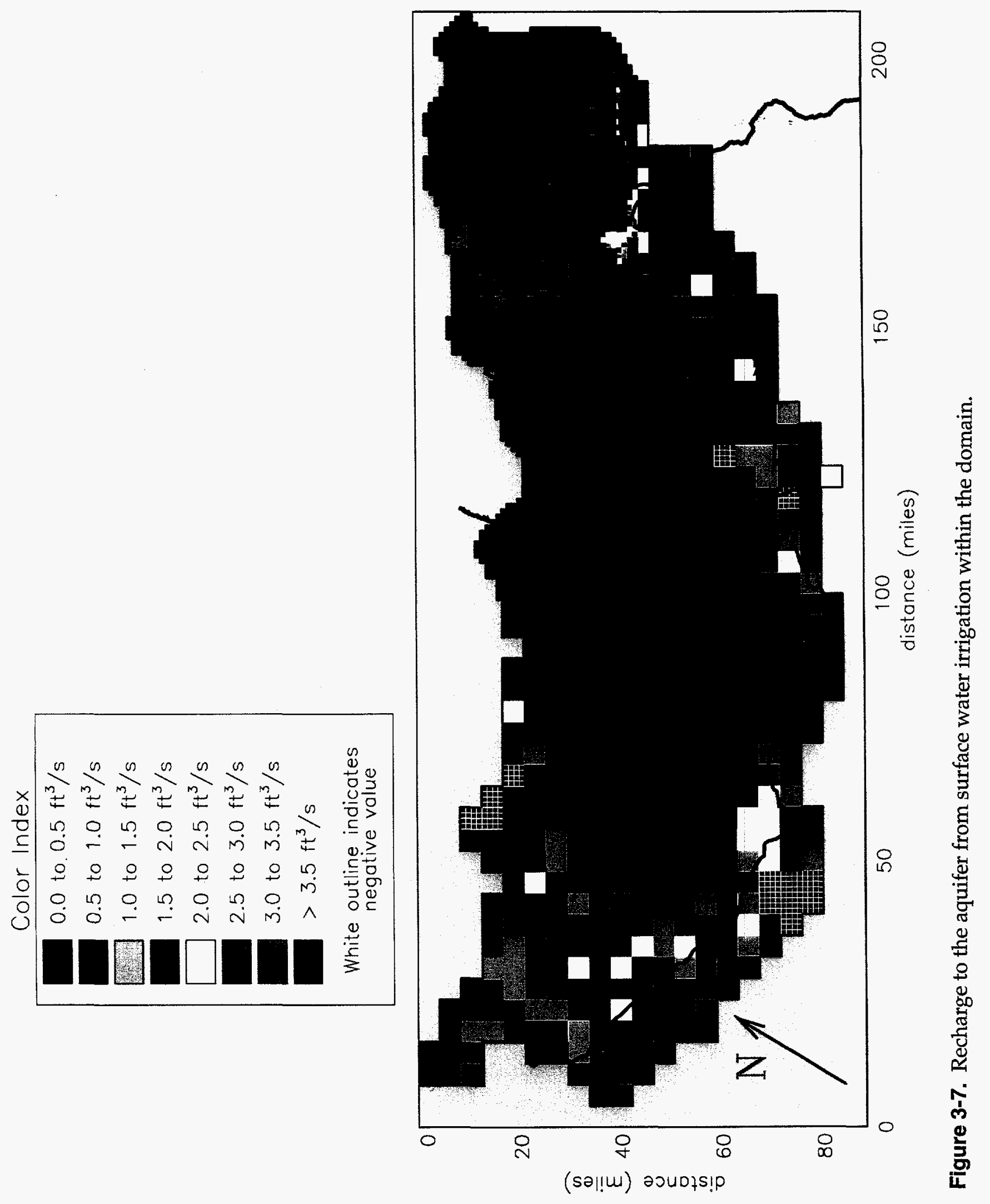




\subsubsection{Underflow}

Underflow values from tributary drainage basins in the current model are based on values calculated in Kjelstrom (1986) (also see Kjelstrom 1990, Table 12) and presented in Garabedian (1992) and Spinazola (1994a). Kjelstrom used drainage basin yield equations to calculate the average annual underflow. His estimates incorporate the following independent variables: (a) recharge area,

(b) mean annual precipitation, and

(c) percentage forest cover.

Spinazola (1994a) estimated monthly underflows for the northeastern tributäry basins by indexing the monthly underflow estimates to water levels near the mouth of Medicine Creek. Figure 3-8 shows the underflow reaches and their estimated underflow. Table 3-6 compares the underflow values used in previous studies with those used in the current model. Table 3-7 shows the mean annual precipitation in each basin and the percentage of the total volume of water attributed to underflow. The underflow total shown in Table 3-7 is different than that shown in Table 3-6 $\left(2,194 \mathrm{ft}^{3} / \mathrm{sec}\right.$ versus $1980 \mathrm{ft}^{3} / \mathrm{sec}$ ) because it was sometimes difficult to separate Garabedian's stream leakage terms from his underflow terms.

Underflow from the Big Lost River, Little Lost River, and Birch Creek valleys is a significant portion of the recharge to the aquifer near the INEL. The transient effects of these underflows on the aquifer are significant for the INEL. Average recharge to the aquifer from tributary valley underflow is presented in Garabedian (1992) and used in the steadystate model. Temporal changes in underflow were indexed to changes in hydraulic head in wells near the boundary of the ESRP aquifer and the corresponding valley outlet. The hydrograph for the Arco-Test well (Figure 3-9) was used as an index for Big Lost River underflow. The Sweet- Sage well hydrograph (Figure 3-10) was used as an index for the Little Lost River underflow. Only early spring data were used from the Sweet-Sage well to avoid seasonal pumping effects on the head at that well. The USGS-025 well hydrograph (Figure 3-11) was used as an index of flow variation with time for Birch Creek underflow. Because of the lack of wells upstream of the mouth of the Birch Creek, a downstream well was used for indexing.

\subsubsection{Total Water Budget}

Table 3-8 compiles the water budget components for 1980 . According to Garabedian (1992) there was a total decrease of aquifer storage of 100,000 acre-ft, which corresponds to $138 \mathrm{ft}^{3} / \mathrm{sec}$ during 1980 .

Groundwater pumpage and gains and losses to the Snake River are the most accurate components of the water budget. Garabedian (1992) reports that the accuracy of the gains and losses are 3 to $10 \%$. Irrigation estimates are also accurate. Recharge values are less accurate because evapotranspiration is difficult to quantify, and precipitation recharge is not easily measured. Precipitation is less than $10 \%$ of the total recharge water budget; therefore, errors in the precipitation charge should have a minor impact on the model.

\subsection{Aquifer Properties}

Groundwater flow in the ESRP aquifer is believed to be primarily in the interflow zones and through fractures in the basalt. The groundwater travels like fractured flow. The current model assumes the flow regime behaves like flow through porous media at large scales and can, therefore, be modeled as a continuum. The model also assumes the geologic units defined in Garabedian (1992) are accurate by adopting the $\mathrm{K}$ values in his model input files. 


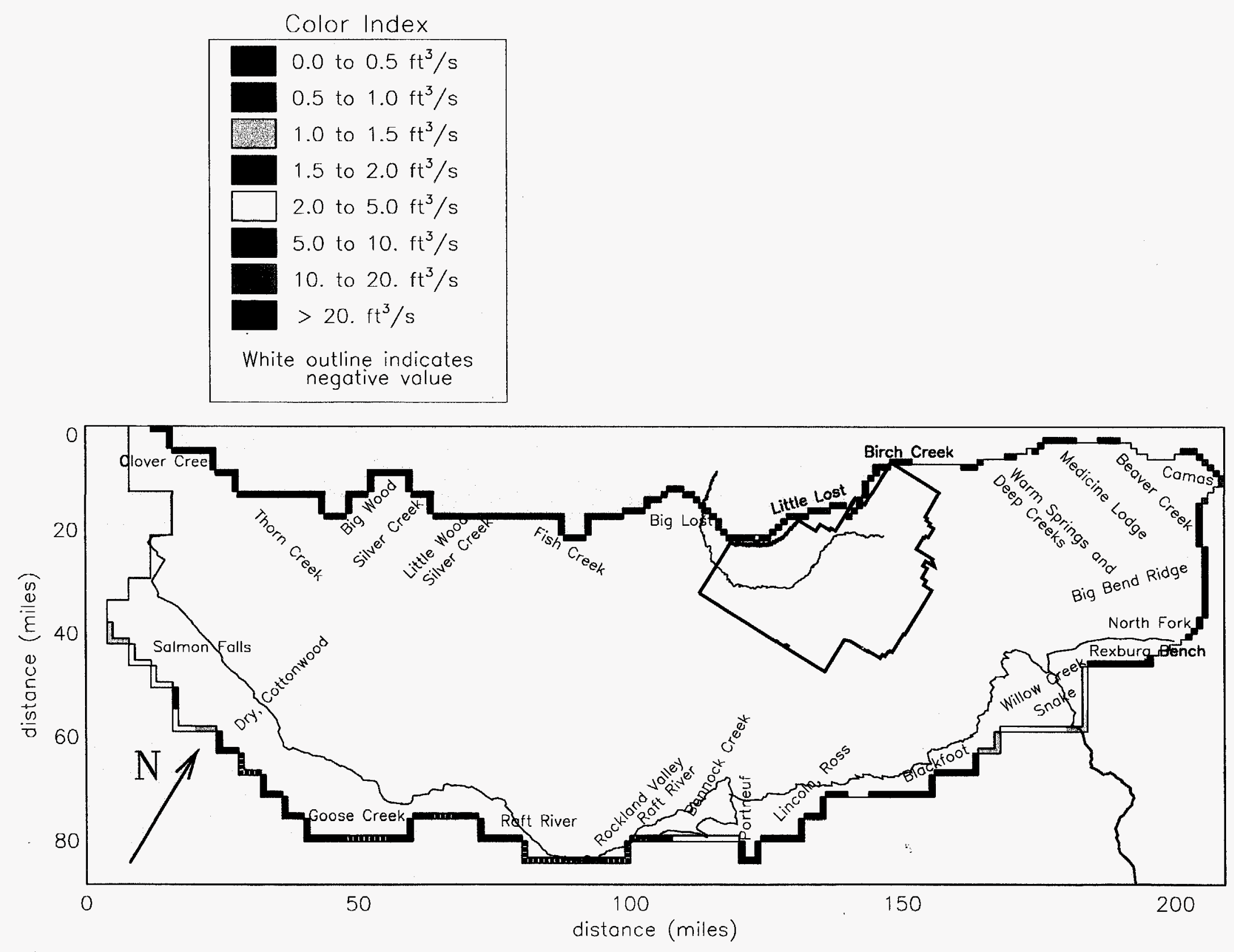

Figure 3-8. Tributary drainage basin underflow reaches. 
Table 3-6. Comparison of various estimated average annual (or 1980) underflows from tributary drainage basins.

\begin{tabular}{|c|c|c|c|c|}
\hline \multirow{2}{*}{$\begin{array}{c}\text { Name } \\
\text { (Plate 1, Garabedian 1992, } \\
\text { Kjelstrom 1986) }\end{array}$} & \multicolumn{4}{|c|}{$\begin{array}{l}\text { Estimated underflow } \\
\qquad\left(\mathrm{ft}^{3} / \mathrm{sec}\right)\end{array}$} \\
\hline & $\begin{array}{l}\text { Kjelstrom (1986) (not } \\
\text { necessarily at basin edge }\end{array}$ & $\begin{array}{l}\text { Garabedian (1992) } \\
\text { input files (Table 11) }\end{array}$ & $\begin{array}{l}\text { Spinazola (1994a) } \\
\text { input files (Figure 27) }\end{array}$ & This report \\
\hline Camas Creek & 208.4 & 214.0 & 214.0 & 214.0 \\
\hline Beaver Creek & 81.4 & 85.6 & 85.6 & 85.6 \\
\hline Medicine Lodge Creek & 11.0 & 12.4 & 12.4 & 12.4 \\
\hline $\begin{array}{l}\text { Warm Springs and Deep } \\
\text { Creeks }\end{array}$ & & 41.4 & 41.4 & 41.4 \\
\hline Birch Creek & 9.7 & 107.7 & 107.7 & 107.7 \\
\hline Little Lost River & 209.8 & 214.0 & & 214.0 \\
\hline Big Lost River & 99.4 & 407.2 & & 407.2 \\
\hline Fish Creek & & 8.3 & & 8.3 \\
\hline Little Wood River & 24.8 & 24.8 & & 24.8 \\
\hline Silver Creek & 69.0 & 73.2 & & 73.2 \\
\hline Big Wood River & & 13.8 & & 13.8 \\
\hline Thorn Creek & & 8.3 & & 8.3 \\
\hline Clover Creek & . & 13.8 & & 13.8 \\
\hline Salmon Falls Creek & 62.1 & 138.0 & & 138.0 \\
\hline $\begin{array}{l}\text { Cottonwood, Rock, and Dry } \\
\text { Creeks }\end{array}$ & & 19.3 & & 19.3 \\
\hline Goose Creek & & 38.7 & & 38.7 \\
\hline Raft River & 113.2 & 116.0 & & 116.0 \\
\hline Rockland Valley (Rock Creek) & 70.4 & 70.4 & & 70.4 \\
\hline Bannock Creek & & 30.4 & & 30.4 \\
\hline Portneuf River & 87.0 & 87.0 & & 87.0 \\
\hline Lincoln and Ross Fork Creeks & & 5.5 & & 5.5 \\
\hline Blackfoot River & & 17.9 & & 17.9 \\
\hline Willow Creek & & 40.0 & & 40.0 \\
\hline Snake River & & 9.7 & & 9.7 \\
\hline Rexburg Bench & & 26.2 & & 26.2 \\
\hline Teton River and Henry's Fork & & 4.1 & 4.1 & 4.1 \\
\hline Big Bend Ridge area & 153.2 & 153.2 & 153.2 & 153.2 \\
\hline Total & $1,199.5$ & $1,980.8$ & 618.4 & $1,980.8$ \\
\hline
\end{tabular}


Table 3-7. Mean annual volume of precipitation for each tributary basin and the percentage attributed to the tributary basin underflow.

\begin{tabular}{|c|c|c|c|c|c|}
\hline $\begin{array}{l}\text { Tributary identifier for each } \\
\text { underflow reach (watershed } \\
\text { number shown in Figure } 2-4)^{a}\end{array}$ & $\begin{array}{c}\text { Total } \\
\text { precipitation } \\
\left(\mathrm{ft}^{3} / \mathrm{sec}\right)\end{array}$ & $\begin{array}{l}\text { Precipitation } \\
\text { outside } \\
\text { numerical } \\
\text { domain } \\
\left(\mathrm{ft}^{3} / \mathrm{sec}\right)\end{array}$ & $\begin{array}{c}\text { Percent } \\
\text { precipitation } \\
\text { outside } \\
\text { numerical } \\
\text { domain }^{b}\end{array}$ & $\begin{array}{l}\text { Underflow } \\
\text { into } \\
\text { numerical } \\
\text { model } \\
\left(\mathrm{ft}^{3} / \mathrm{sec}\right)\end{array}$ & $\begin{array}{l}\text { Percent of } \\
\text { maximum } \\
\text { possible } \\
\text { underflow }\end{array}$ \\
\hline & Column A & Column B & $\frac{\text { Column B }}{\text { Column A }}$ & Column D & $\frac{\text { Column D }}{\text { Column B }}$ \\
\hline $\begin{array}{l}\text { Camas } \mathrm{Cr} \text {, Beaver } \mathrm{Cr} \text {, Medicine } \\
\text { Lodge } \mathrm{Cr}(44)\end{array}$ & 1,239 & 621 & 50 & 309 & 50 \\
\hline $\begin{array}{l}\text { Medicine Lodge Cr, Warm Springs } \\
\text { and Deep Creeks (45) }\end{array}$ & 833 & 608 & 73 & 44 & 7 \\
\hline Little Lost River, Birch Cr (46) & 1,147 & 1,128 & 98 & 201 & 18 \\
\hline Birch Creek (47) & 780 & 681 & 87 & 138 & 20 \\
\hline $\begin{array}{l}\text { Henry's Fork of Snake River, Big } \\
\text { Bend Ridge Area }(39,48)\end{array}$ & 3,308 & 2,906 & 88 & 152 & 5 \\
\hline Big Lost River, Little Lost River (50) & 2,282 & 2,085 & 91 & 369 & 18 \\
\hline $\begin{array}{l}\text { Willow Cr, Snake River, Rexburg } \\
\text { Bench, Blackfoot River } \\
(51,61,63,69,85,86,87)\end{array}$ & 3,660 & 3,150 & 86 & 61 & 2 \\
\hline $\begin{array}{l}\text { Willow Cr, Snake River, Rexburg } \\
\text { Bench, Blackfoot River (51) }\end{array}$ & 688 & 177 & 26 & 61 & 34 \\
\hline Rexburg Bench (54) & 1,014 & 954 & 94 & 15 & 2 \\
\hline $\begin{array}{l}\text { Big Wood River, Thorn Cr, Clover } \\
\text { Cr }(56,64)\end{array}$ & 2,881 & 2,633 & 91 & 24 & 1 \\
\hline $\begin{array}{l}\text { Fish } \mathrm{Cr} \text {, Silver Cr, Big Wood River, } \\
\text { Little Wood River (59) }\end{array}$ & 1,128 & 694 & 62 & 105 & 15 \\
\hline $\begin{array}{l}\text { Raft River, Bannock Cr, Lincoln } \\
\text { and Ross Fork Creeks, Blackfoot } \\
\text { River (60) }\end{array}$ & 1,835 & 843 & 46 & 43 & 5 \\
\hline $\begin{array}{l}\text { Big Lost River, Raft River, Fish Cr, } \\
\text { Goose Cr, Rockland Valley (62) }\end{array}$ & 1,892 & 608 & 32 & 190 & 31 \\
\hline $\begin{array}{l}\text { Lincoln and Ross Fork Creeks, } \\
\text { Blackfoot River (66) }\end{array}$ & 1,461 & 1,436 & 98 & 2.6 & 0 \\
\hline $\begin{array}{l}\text { Clover Cr, Salmon Falls Cr, } \\
\text { Cottonwood, Rock and Dry } \\
\text { Creeks, Goose Cr }(65,67,75)\end{array}$ & 2,409 & 1,305 & 54 & 156 & 6 \\
\hline
\end{tabular}


Table 3-7. (continued).

\begin{tabular}{|c|c|c|c|c|c|}
\hline $\begin{array}{l}\text { Tributary identifier for each } \\
\text { underflow reach (watershed } \\
\text { number shown in Figure 2-4) }\end{array}$ & $\begin{array}{c}\text { Total } \\
\text { precipitation } \\
\left(\mathrm{ft}^{3} / \mathrm{sec}\right)\end{array}$ & $\begin{array}{l}\text { Precipitation } \\
\text { outside } \\
\text { numerical } \\
\text { domain } \\
\left(\mathrm{ft}^{3} / \mathrm{sec}\right)\end{array}$ & $\begin{array}{c}\text { Percent } \\
\text { precipitation } \\
\text { outside } \\
\text { numerical } \\
\text { domain }^{b}\end{array}$ & $\begin{array}{l}\text { Underflow } \\
\text { into } \\
\text { numerical } \\
\text { model } \\
\left(\mathrm{ft}^{3} / \mathrm{sec}\right)\end{array}$ & $\begin{array}{l}\text { Percent of } \\
\text { maximum } \\
\text { possible } \\
\text { underflow }\end{array}$ \\
\hline & Column A & Column B & $\frac{\text { Column B }}{\text { Column A }}$ & Column D & $\frac{\text { Column D }}{\text { Column B }}$ \\
\hline Portneuf River (70) & 1,692 & 1,676 & 99 & 87 & 5 \\
\hline Raft River (77) & 1,068 & 1,065 & 100 & 0.09 & 0 \\
\hline Goose Creek (80) & 650 & 580 & 89 & 13 & 2 \\
\hline Totals & 29,966 & 23,151 & 77 & 1,970 & 9 \\
\hline
\end{tabular}

a. The grids defined as different underflow reaches extend into more than one tributary drainage area.

Therefore, a tributary can fall under more than one underflow reach.

b. Percent of underflow used in the numerical model to precipitation that falls outside the numerical model domain.

c. Data for watersheds number 85,86 , and 87 are not available at this time; therefore, the precipitation values in this tributary are significantly underestimated. 


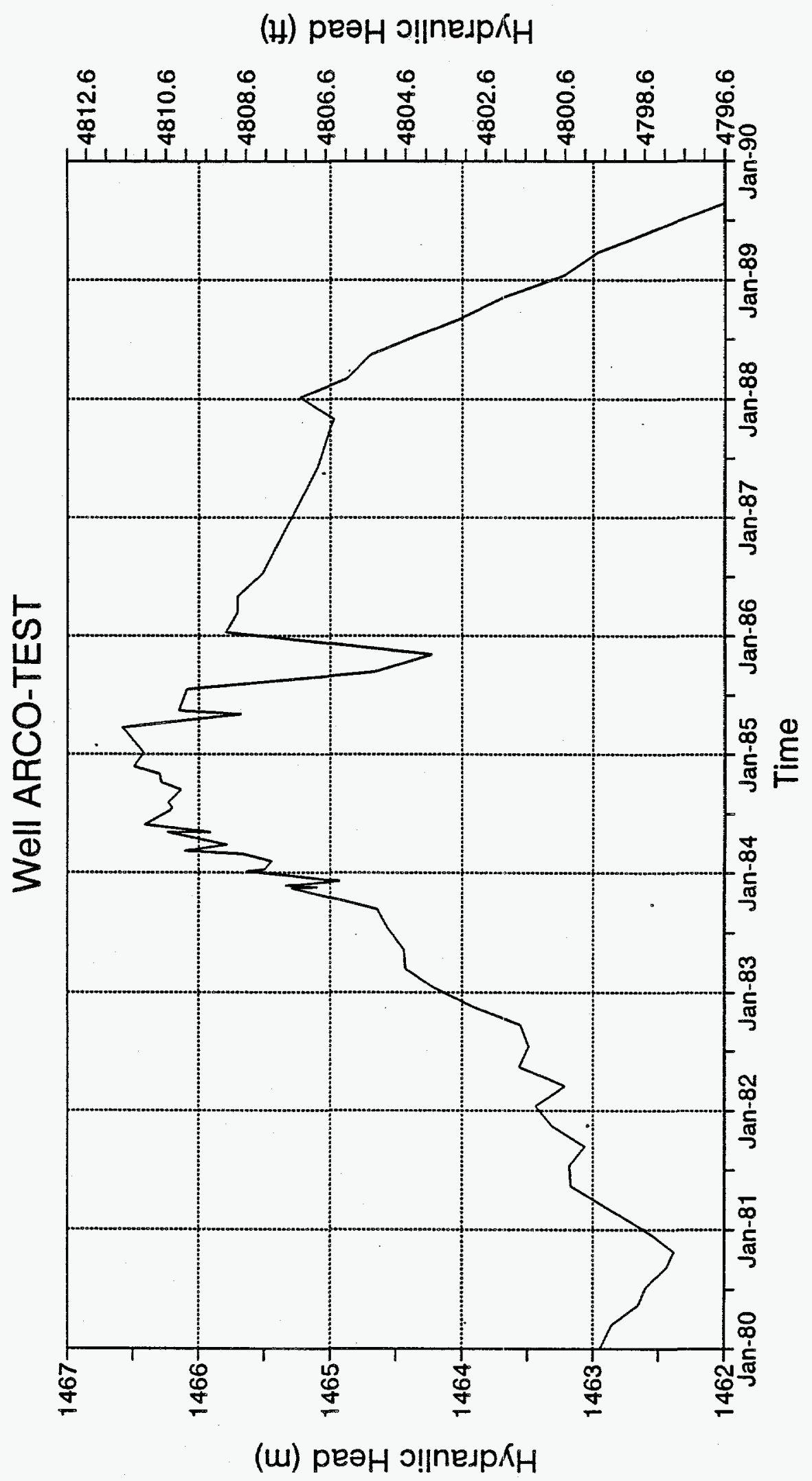

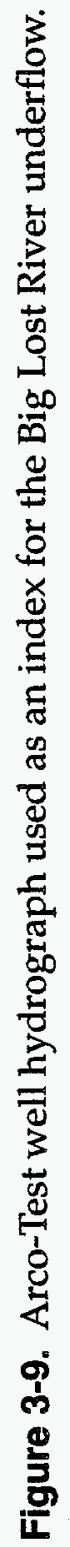


(H) реән О!пnедр $\aleph_{H}$

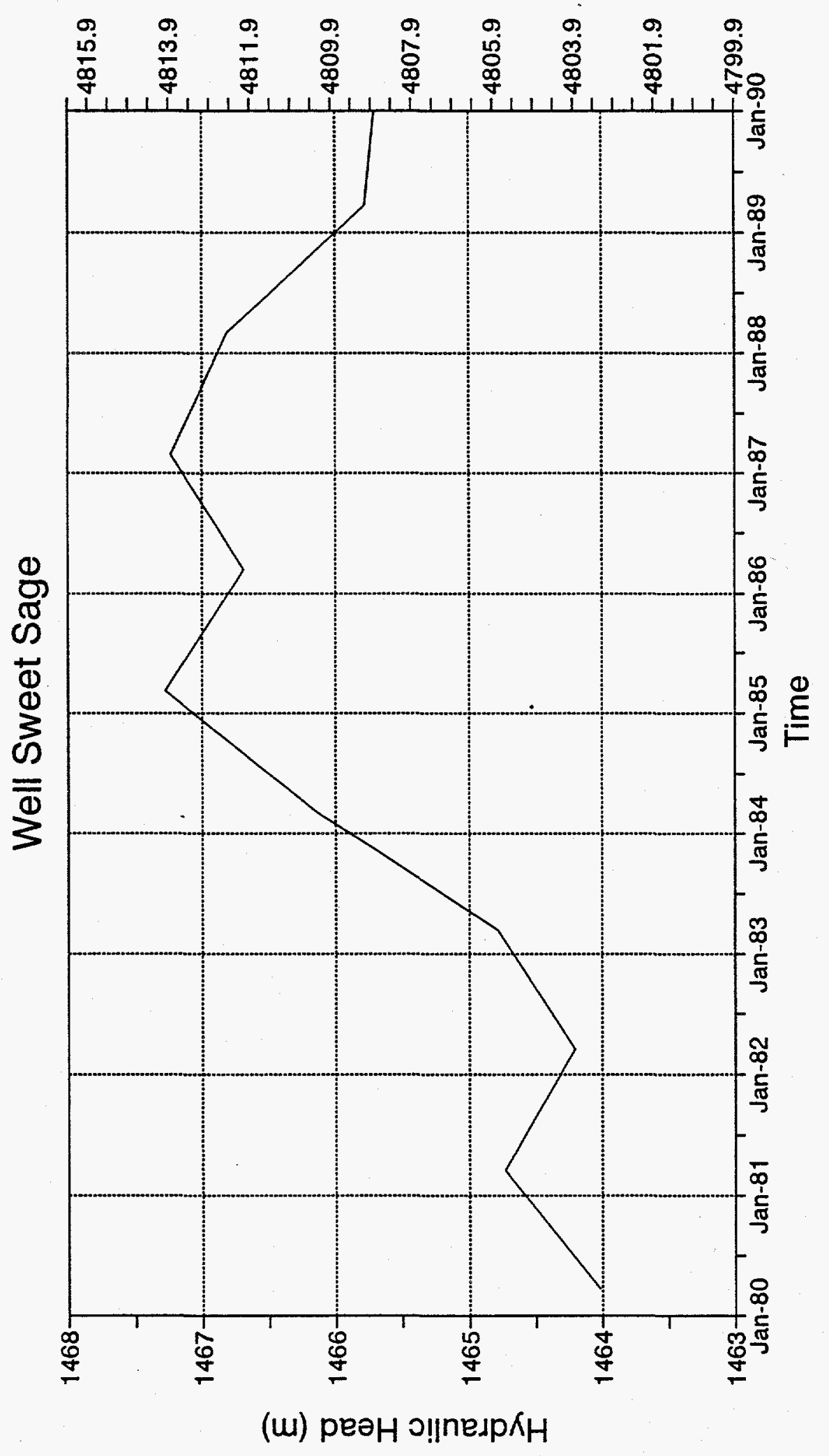

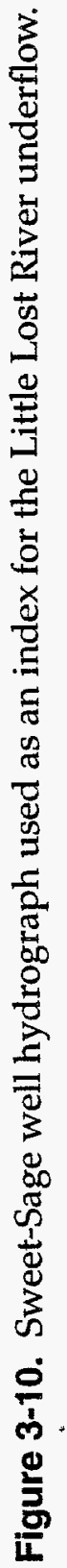


Well USGS-025

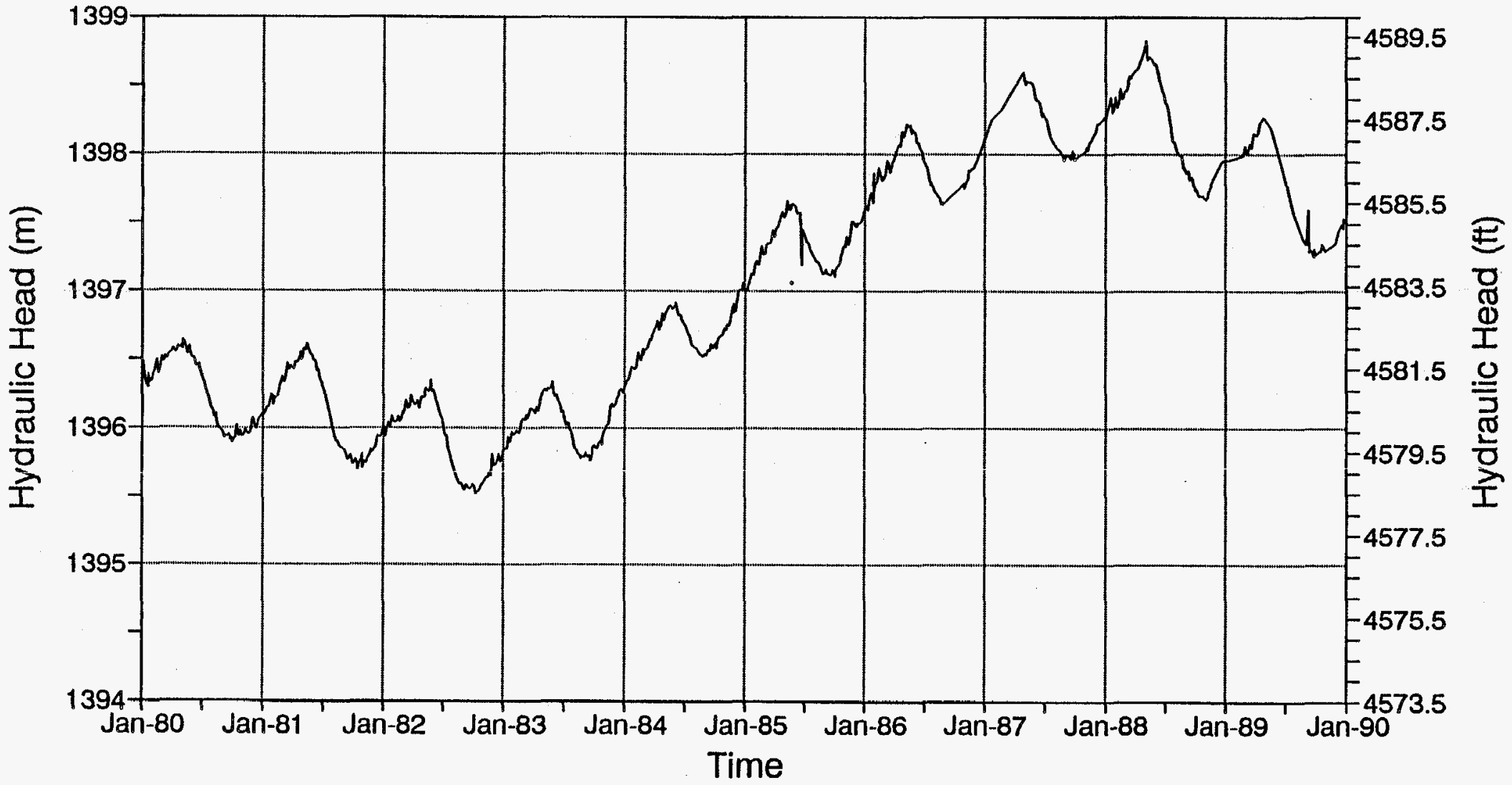

Figure 3-11. USGS-025 well hydrograph used as an index for the Birch Creek underflow. 
Table 3-8. Groundwater budget, water year 1980.

\begin{tabular}{|c|c|}
\hline Recharge & $\begin{array}{l}\text { Cubic feet } \\
\text { per second }\end{array}$ \\
\hline $\begin{array}{l}\text { Recharge from irrigation } \\
\text { and precipitation }\end{array}$ & 7,349 \\
\hline $\begin{array}{l}\text { Tributary drainage-basin } \\
\text { underflow }\end{array}$ & 1,970 \\
\hline Snake River losses & 952 \\
\hline $\begin{array}{l}\text { Tributary-stream and canal } \\
\text { losses }\end{array}$ & 562 \\
\hline Total & 10,833 \\
\hline \multicolumn{2}{|l|}{ Discharge } \\
\hline Snake River gains & 9,756 \\
\hline $\begin{array}{l}\text { Groundwater pumpage } \\
\text { (net) }\end{array}$ & 1,483 \\
\hline Total & 11,239 \\
\hline $\begin{array}{l}\text { Change in aquifer storage } \\
\text { (budget residual) }\end{array}$ & -406 \\
\hline $\begin{array}{l}\text { Estimated change in } \\
\text { aquifer storage from water } \\
\text { level changes }\end{array}$ & -138 \\
\hline
\end{tabular}

The upper portion of the aquifer is unconfined over most of the domain. If the upper layer of the aquifer was assumed to be very thin, it would have to be simulated as unconfined (nonlinear mathematical representation). However because the upper layer is assumed to be $200 \mathrm{ft}$ deep, which is large compared to the fluctuations of the water table, it was assumed that the flow in the upper layer behaves as confined flow. This significantly simplifies the mathematical representation of the problem so the numerical model converges easier and quicker. For the transient simulations, a storage coefficient that represents the specific yield must be used to simulate unconfined response to transient boundary conditions.

Vertical groundwater flow is modeled as simple Darcy leakage. The values of vertical conductances between layers 1 and 2, 2 and 3, and 3 and 4 are $5.79 \times 10^{-9}, 2.89 \times 10^{-9}$, and $1.45 \times 10^{-9}\left(\mathrm{sec}^{-1}\right)$, respectively. These values correspond to the values used in the Spinazola model for vertical conductivities between his original layers 2 and 3, 3 and 4, and 4 and 5, respectively. Garabedian (1992) defines a more complex function that varies over space. For the current model, Spinazola's uniform vertical conductances are used because the system's unknown components do not justify a more complex model.

The $\mathrm{K}$ values in the current model are defined using a zonation approach, where the domain is divided into zones of equal $\mathrm{K}$. The zones were initially defined based on Garabedian's layer $1 \mathrm{~K}$ zones (Figure 3-12). The $\mathrm{K}$ values were assumed to be equal to the average values estimated from Garabedian's transmissivity values. The average of Spinazola's layers 1 and $2 \mathrm{~K}$ zones were used in the northeastern portion of the domain (Figure 3-13). In the vicinity of the INEL, new zones were defined to accurately simulate the hydraulic head variations across the INEL Site based on the EIS model K zones (Figure 3-14) and the FY 93 WAG $10 \mathrm{~K}$ zones (Figure 3-15). The INEL zones were later modified during the calibration process.

\section{Using average $\mathrm{K}$ values in a zonation} approach simplifies the approach taken by Garabedian and Spinazola. Both Garabedian and Spinazola discretized the ESRP aquifer by rock type (Garabedian 1992, Plate 5). The K zones shown in Garabedian (1992) (Plate 6) generally divide the domain into zones of like 


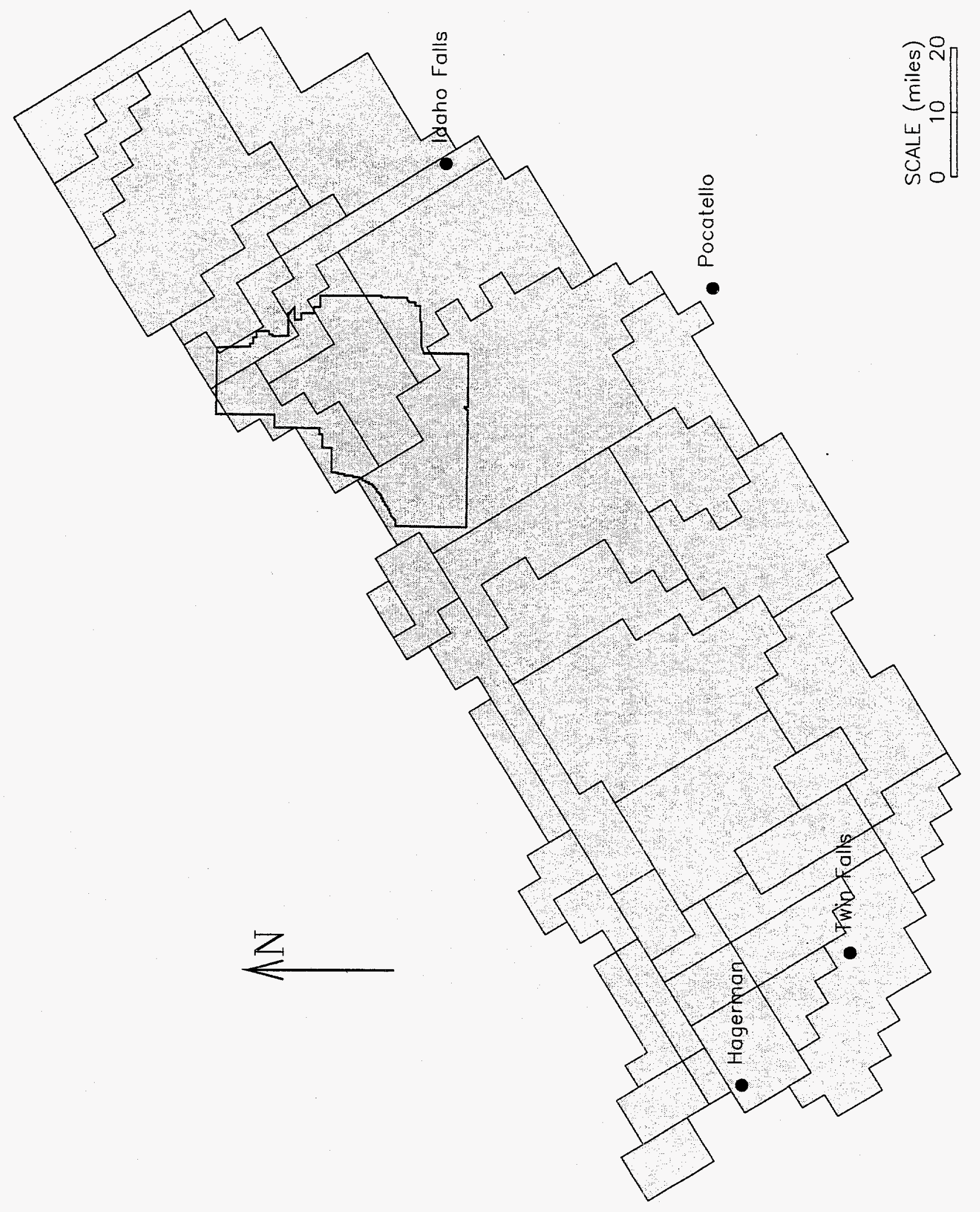

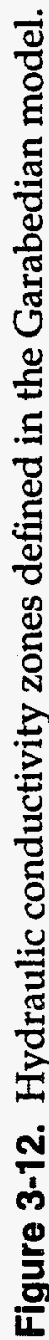




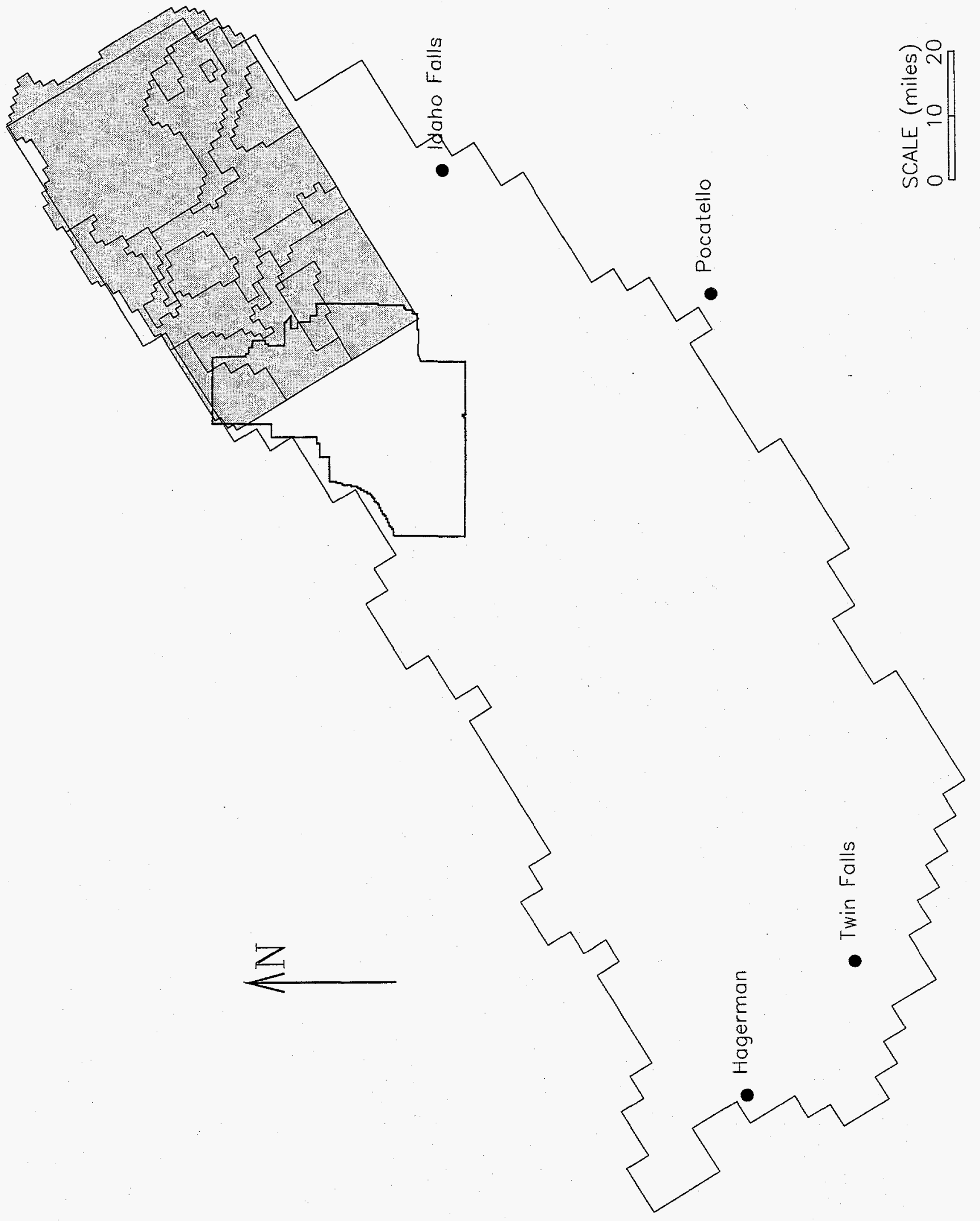

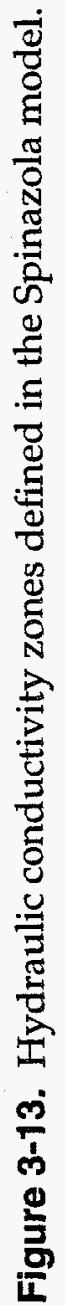




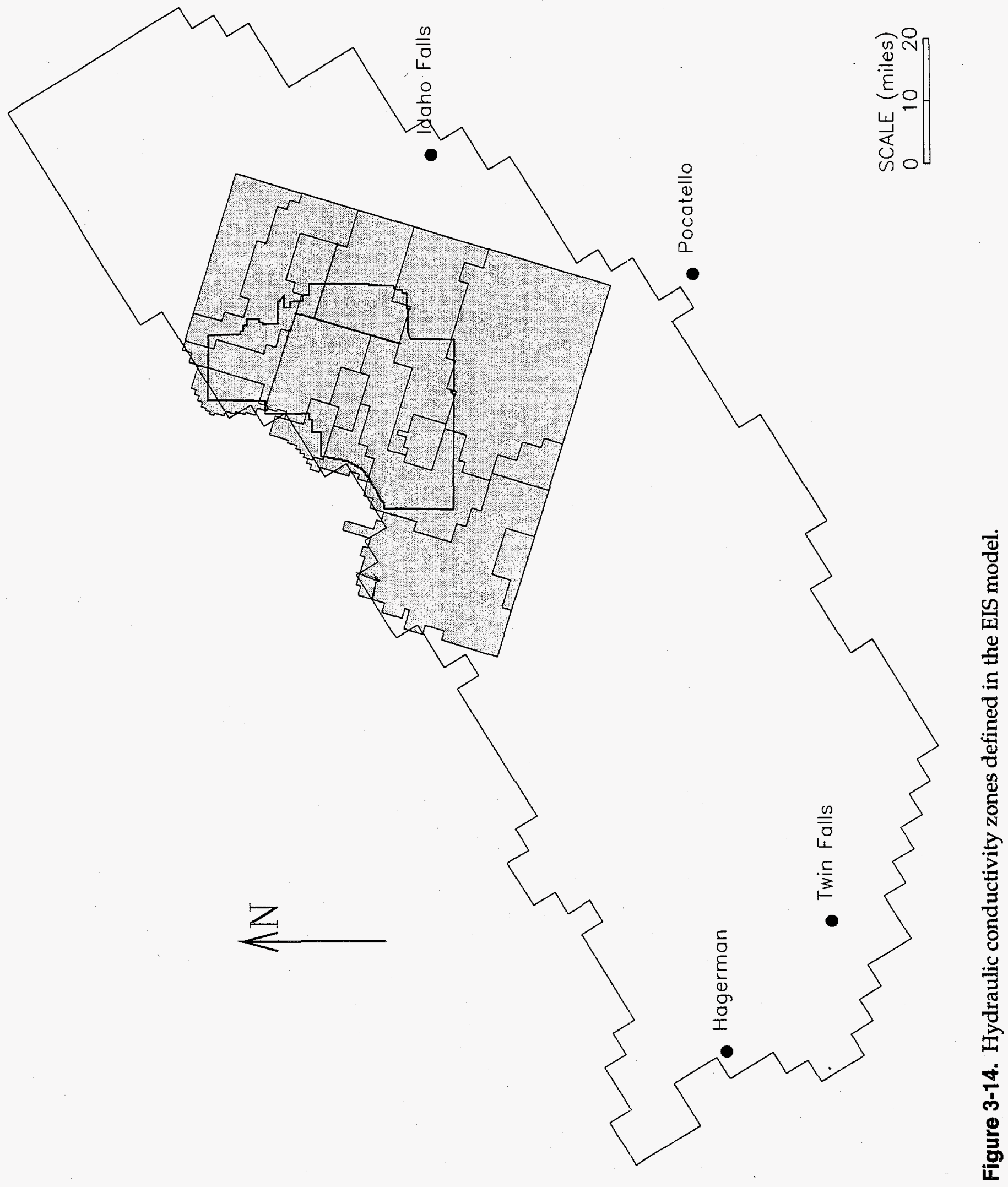




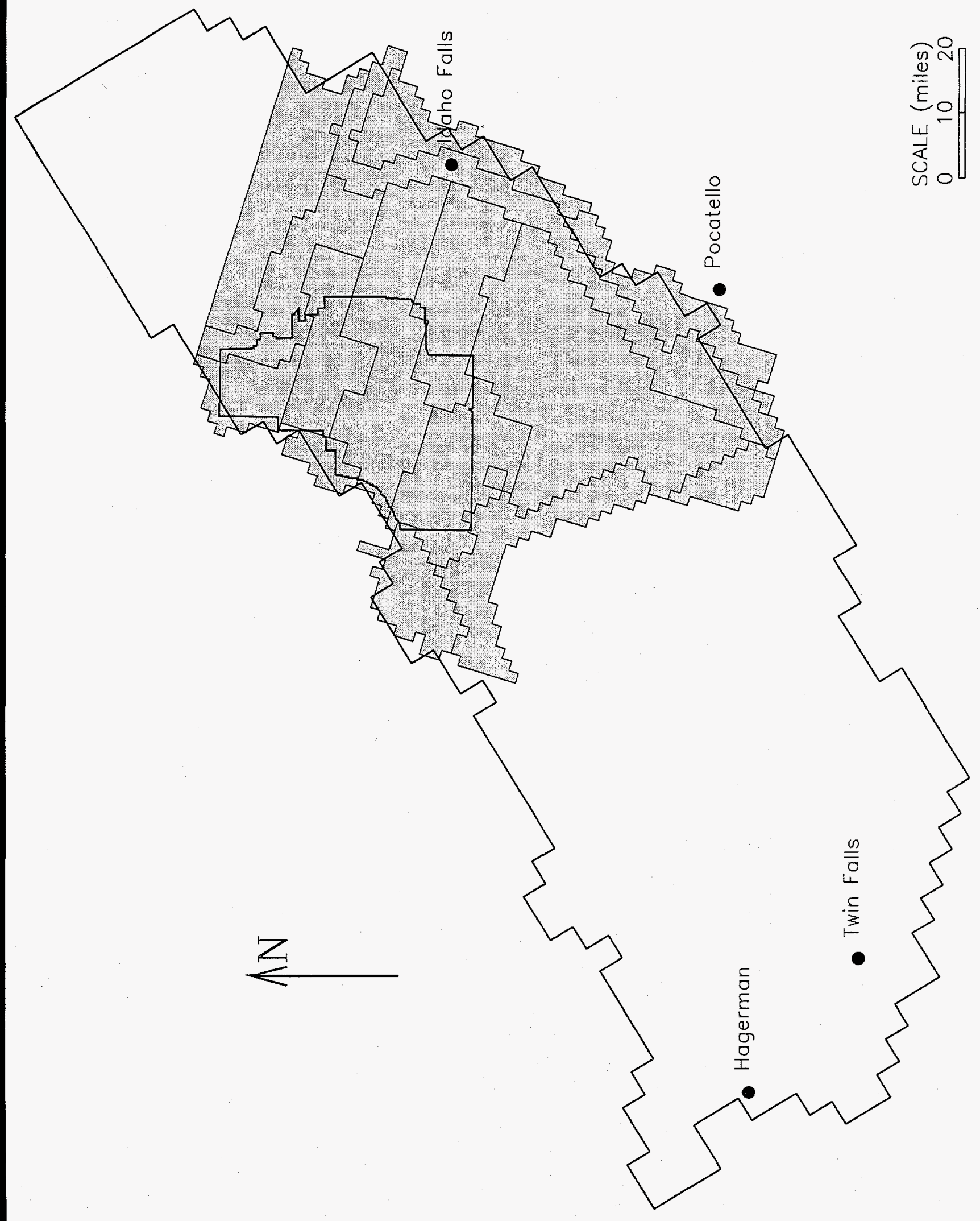

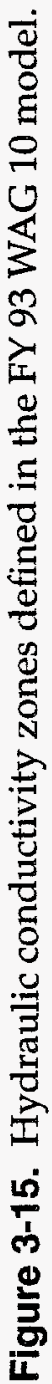


$\mathrm{K}$ values. However, a zone can cover more than one rock type, and the assigned values vary as a function of the rock type. Over an area the same zone definition is used for all four layers. Spinazola's K zones are defined more closely by rock type, but the zone definitions are different for different layers.

In the current model the areal extent of the $\mathrm{K}$ zones are the same in all four layers. In a layer, each $K$ zone is assigned a constant $K$ value. To assign $K$ values to layers 2, 3 and 4, average $K$ values from the Garabedian and Spinazola models were calculated for each $\mathrm{K}$ zone in each layer. The $\mathrm{K}$ values in layer 1 were multiplied by factors to approximate the Garabedian and Spinazola layer 2, 3, and 4 values. In the vicinity of the INEL, it was assumed that the $\mathrm{K}(\mathrm{a})$ in layer 2 is the same as the $K$ in layer 1 , (b) in layer 3 is $2 / 3$ the value of the $K$ in layer 1 , and (c) in layer 4 is $1 / 3$ the value of the $K$ in layer 1 (this assumption was also made in the Garabedian and Spinazola models). Transmissivity values are calculated by multiplying the $\mathrm{K}$ by the aquifer thickness.
To integrate the Garabedian and Spinazola models, layers 1 and 2 of the Spinazola model had to be combined, which required redefining $\mathrm{K}$ zones and assigning new average values. The current model assumes that the average $\mathrm{K}$ zones and average values defined by Garabedian and Spinazola are acceptable for all areas outside the vicinity of the INEL. Figure 3-16 shows the numerical model domain and outlines the $\mathrm{K}$ zones. Zones numbered 1 to 40 are defined by Garabedian, zones numbered 51 to 65 are defined by the current model, and zones numbered greater than 70 are defined by Spinazola. Table 3-9 shows the layer 1 initial values of $K$ assumed for this model and the factors used to define the $K$ values in layers 2,3 , and 4 .

For the current model's transient simulations, the storage coefficient is assumed to be constant in each layer. The layer 1 storage coefficient was initially assumed to be 0.1 to simulate unconfined flow. The layers 2,3 , and 4 storage coefficients are assumed to be $1 \times 10^{-4}$. This simulates confined conditions and is consistent with the values used by Garabedian. 


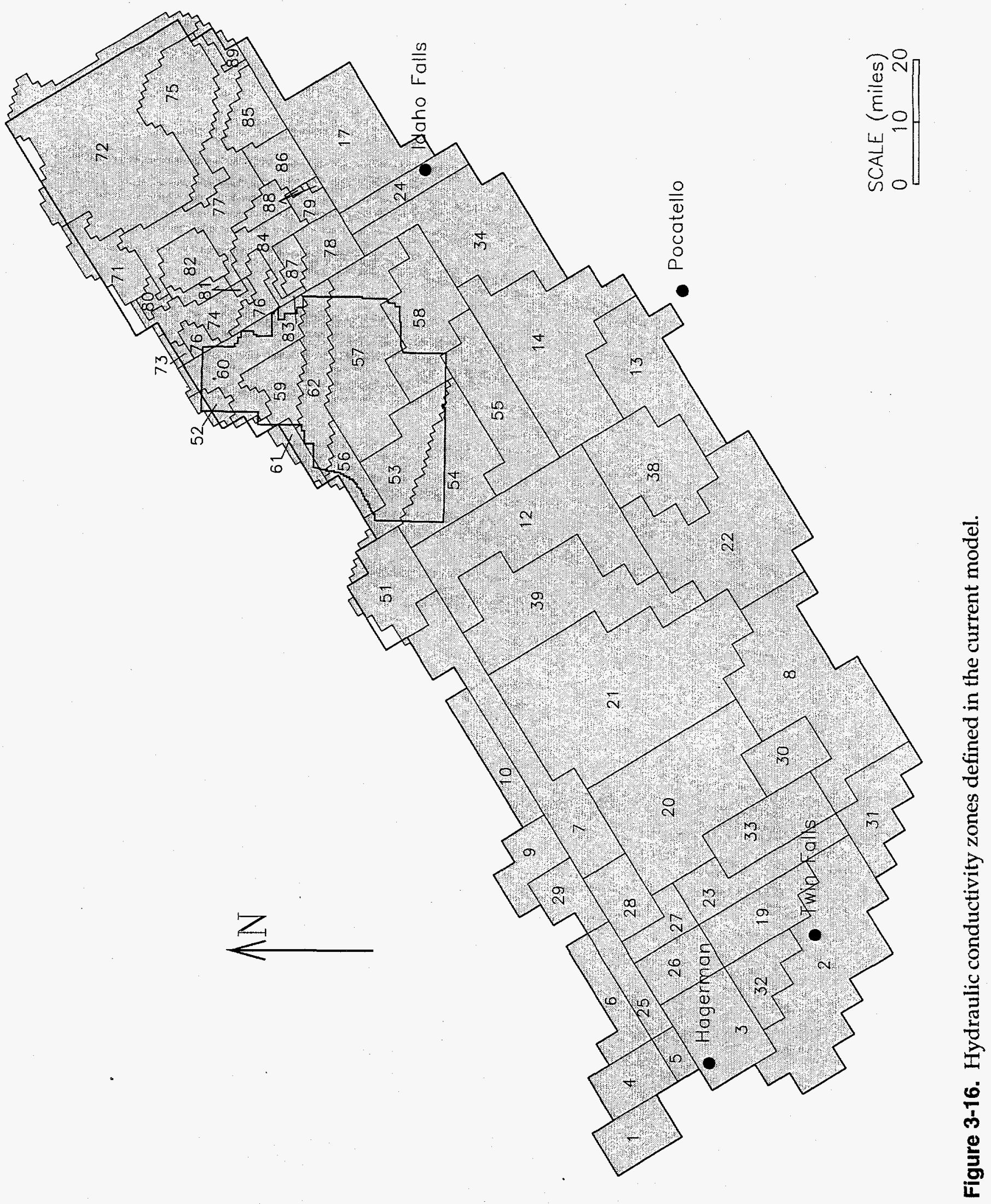


Table 3-9. Comparison of the layer $1 \mathrm{~K}$ values used for the current model and the factors used to calculate the $\mathrm{K}$ values in layers 2,3 , and 4

$\mathrm{K}$ value fractional multiplier for layer

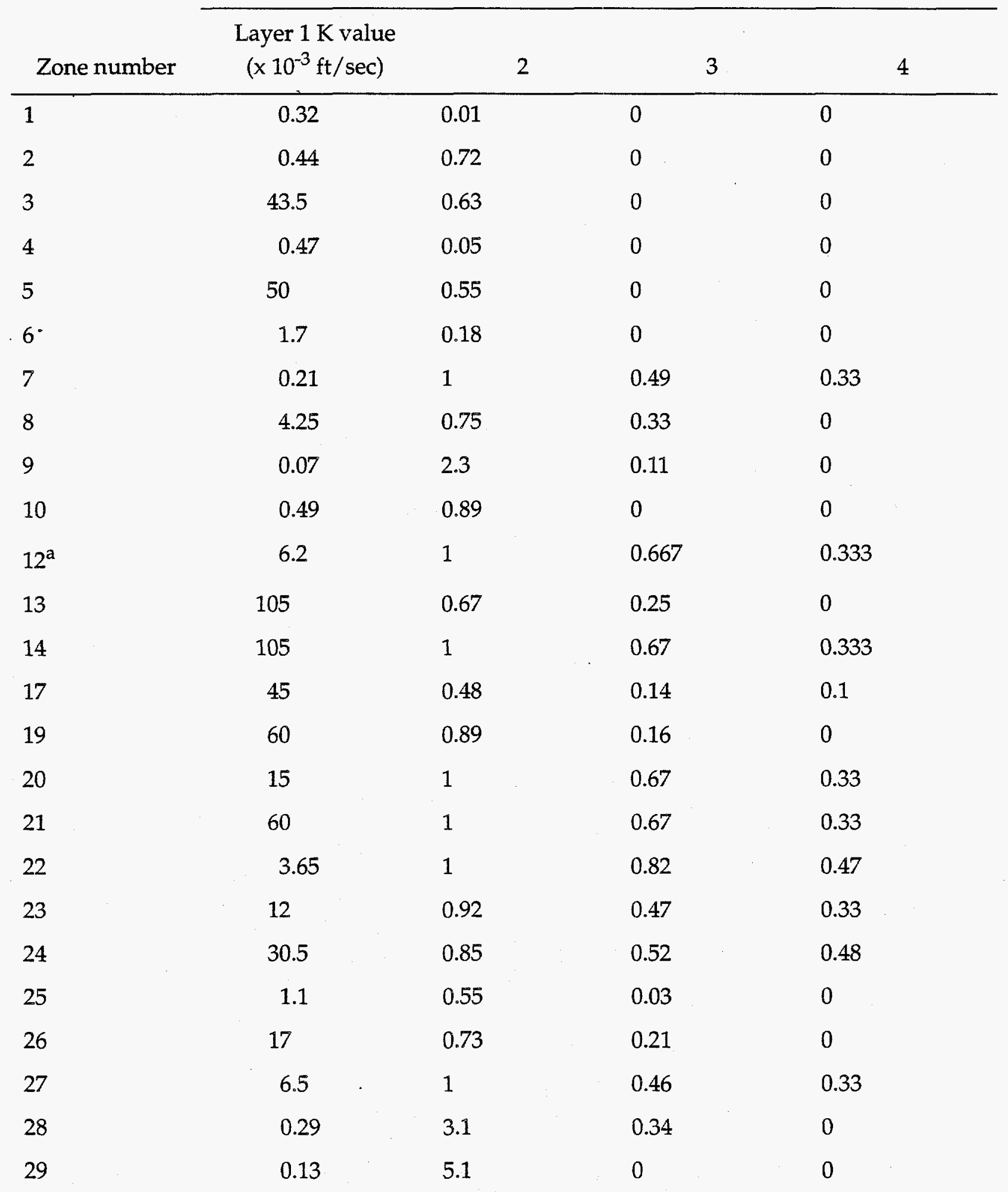


Table 3-9. (continued).

$\mathrm{K}$ value fractional multiplier for layer

\begin{tabular}{|c|c|c|c|c|}
\hline Zone number & $\begin{array}{c}\text { Layer } 1 \mathrm{~K} \text { value } \\
\left(\times 10^{-3} \mathrm{ft} / \mathrm{sec}\right)\end{array}$ & 2 & 3 & 4 \\
\hline 30 & 0.32 & 0.67 & 0.7 & 0.41 \\
\hline 31 & 0.12 & 0.81 & 0 & 0 \\
\hline 32 & 30.5 & 0.43 & 0 & 0 \\
\hline 33 & 4.2 & 0.95 & 0.52 & 0.33 \\
\hline 34 & 0.32 & 0.9 & 0.53 & 0.33 \\
\hline 38 & 13 & 1 & 0.55 & 0.33 \\
\hline 39 & 12 & 1 & 0.67 & 0.33 \\
\hline $51^{a}$ & 1.7 & 1 & 0.667 & 0.333 \\
\hline 52 & 11.2 & 1 & 0.667 & 0.333 \\
\hline $53^{a}$ & 5.3 & 1 & 0.667 & 0.333 \\
\hline $54^{\mathrm{a}}$ & 57 & 1 & 0.667 & 0.333 \\
\hline $55^{\mathrm{a}}$ & 52.9 & 1 & 0.667 & 0.333 \\
\hline $56^{\mathrm{a}}$ & 3.64 & 1 & 0.667 & 0.333 \\
\hline $57^{\mathrm{a}}$ & 11.6 & 1 & 0.667 & 0.333 \\
\hline $58^{a}$ & 96.2 & 1 & 0.667 & 0.333 \\
\hline $59^{a}$ & 7.72 & 1 & 0.667 & 0.333 \\
\hline $60^{a}$ & 7.56 & 1 & 0.667 & 0.333 \\
\hline $61^{a}$ & 0.82 & 1 & 0.667 & 0.333 \\
\hline $62^{a}$ & 1.33 & 1 & 0.667 & 0.333 \\
\hline 71 & 0.29 & 0.95 & 0.67 & 0 \\
\hline 72 & 0.58 & 1 & 0.67 & 0.33 \\
\hline 73 & 17.4 & 0.97 & 0.67 & 0 \\
\hline 74 & 0.44 & 1 & 0.67 & 0.33 \\
\hline 75 & 57 & 0.72 & 0.87 & 0.09 \\
\hline 76 & 0.01 & 29.1 & 0.67 & 0.33 \\
\hline 77 & 49.2 & 0.87 & 0.52 & 0.09 \\
\hline
\end{tabular}


Table 3-9. (continued).

$K$ value fractional multiplier for layer

\begin{tabular}{lclll}
\cline { 2 - 4 } Zone number & $\begin{array}{c}\text { Layer 1 K value } \\
\left(\times 10^{-3} \mathrm{ft} / \mathrm{sec}\right)\end{array}$ & 2 & 3 & 4 \\
\hline 78 & 28.94 & 0.61 & 0.27 & 0.22 \\
79 & 2.05 & 0.13 & 0.09 & 0.14 \\
80 & 1.81 & 0.71 & 0.67 & 0 \\
81 & 4.05 & 1.2 & 0.33 & 0.43 \\
82 & 57.8 & 1 & 0.21 & 0.12 \\
83 & 0.45 & 0.0012 & 0.00049 & 0.007 \\
84 & 5.01 & 0.02 & 0.01 & 0.03 \\
85 & 16.8 & 2.2 & 0.67 & 0.33 \\
86 & 28.4 & 1.3 & 0.85 & 1.2 \\
87 & 19.6 & 0.86 & 0.57 & 1.4 \\
88 & 8.19 & 0.17 & 0.08 & 0.05 \\
89 & 16.8 & 0.023 & 0 & 0 \\
\hline a. & Zones used in the calibration & & & \\
\hline
\end{tabular}




\section{NUMERICAL MODEL DESIGN}

This chapter explains the mechanics of numerically modeling the conceptual model and integrating previous regional numerical models. The numerical model integrates the Garabedian, Spinazola, EIS, and WAG 10 models previously discussed in this report. The Garabedian, Spinazola, and EIS models used MODFLOW (McDonald and Harbaugh 1988) to develop their numerical models. This flow model uses the USGS code MODFLOWP (Hill 1992) to develop numerical models.

MODFLOWP is a parameter estimation code that has been integrated with MODFLOW. MODFLOWP functions like MODFLOW if the MODFLOWP Parameter Estimation Package is not used. If the Parameter Estimation Package is used, the MODFLOW input may require some minor modifications before it can be used by MODFLOWP (see MODFLOWP documentation, Hill 1992).

Sections 4.1 and 4.2 discuss input files for the MODFLOW and MODFLOWP packages. Complete copies of the small input files and partial copies of larger input files are presented in the discussion. All input files are available from the Hydrologic Data Repository and maintained by WAG 10.

\subsection{MODFLOW Input}

The groundwater flow simulation used the following 10 MODFLOW packages: (1) Basic Package, (2) Output Control Package, (3) Block Center Flow Package, (4) River Package, (5) Recharge Package, (6) Well Package, (7) Drain Package, (8) General-Head Package, (9) Preconditioned Conjugate Gradient Package, and (10) Stream Package.

\subsubsection{Basic Package}

Figure 4-1 is the Basic Package input file for the pseudo steady-state (1980) groundwater simulation. The numerical model is discretized into $1 \times 1$-mi grids (84 rows and 209 columns). Four aquifer layers are simulated using the four layer depths defined by the Parameter Estimation Package.

Consistent with the Garabedian model, time is measured in seconds and the length is measured in feet.

The domain boundary for the numerical model is defined with the IBOUND flag array (units 41 through 44 defined in the Basic Package input file). The $84 \times 209$ matrix within the model domain denotes active nodes with 0 s and inactive nodes with $1 \mathrm{~s}$. Negative $1 \mathrm{~s}$ can denote prescribed head nodes, but they are not used for this model.

The IBOUND array was generated using the following steps:

1. Using the Garabedian IBOUND array $4 \times 4$-mi grid and boundaries of the domain, the grid was refined to $1 \times 1 \mathrm{mi}$ throughout the model domain

2. Using the Spinazola $1 \times 1-\mathrm{mi}$ grid, the Spinazola IBOUND array was superimposed on the refined Garabedian IBOUND array

3. In the vicinity of the INEL, minor modifications were made to the IBOUND array to more accurately define the domain boundary in the area of the Big Lost River and Little Lost River valleys. These modifications were based on the domain definition of the EIS and FY 93 WAG 10 models.

Figures 4-2 through 4-6 show the numerical model domain and discretization for the Garabedian model (Figure 4-2), Spinazola model (Figure 4-3), EIS model (Figure 4-4), FY 93 WAG 10 model (Figure 4-5), and current model (Figure 4-6). 
EASTERN SNAKE RIVER PLAIN 3-D GW FLOW MODEL, 4 LAYER,S, STEADY-STATE (1980)

Combination of Garabedian's and Spinazola's models.

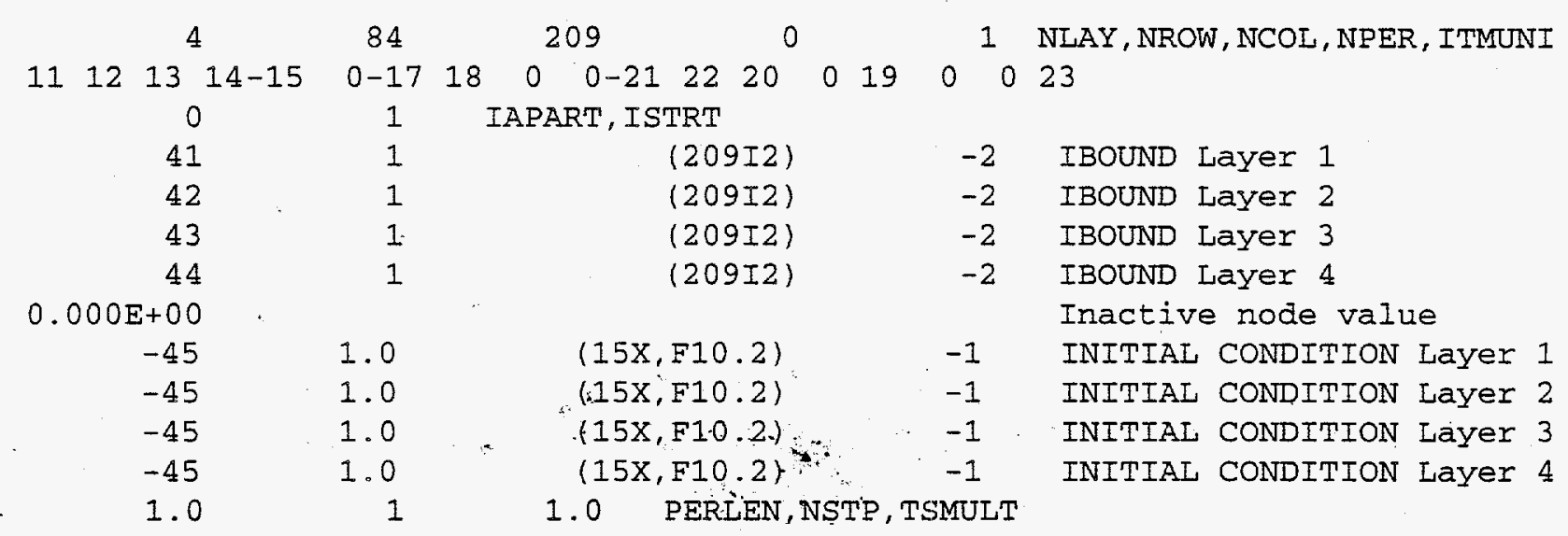

Figure 4-1. Basic Package input file for the pseudo steady state (1980) simulation. 


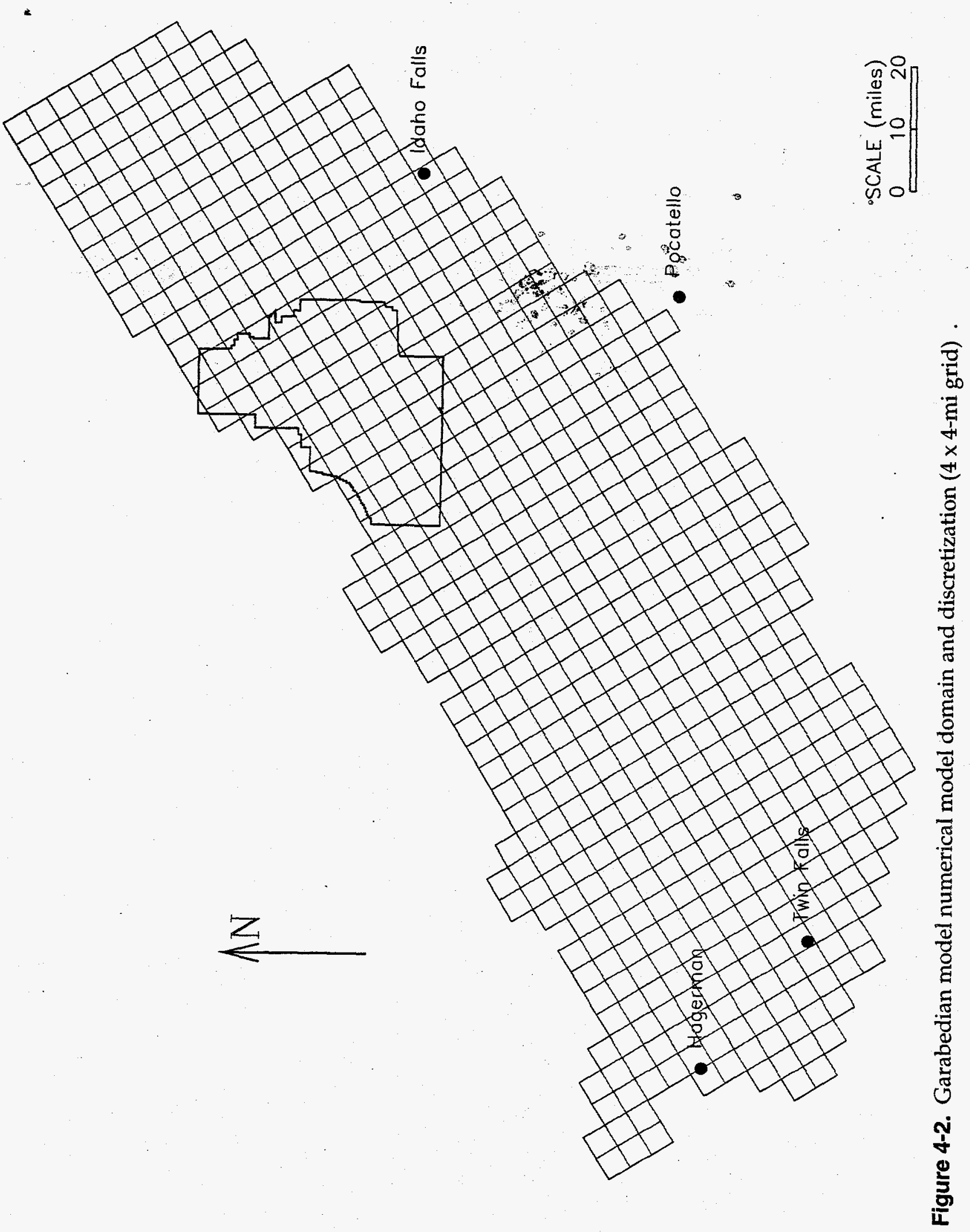




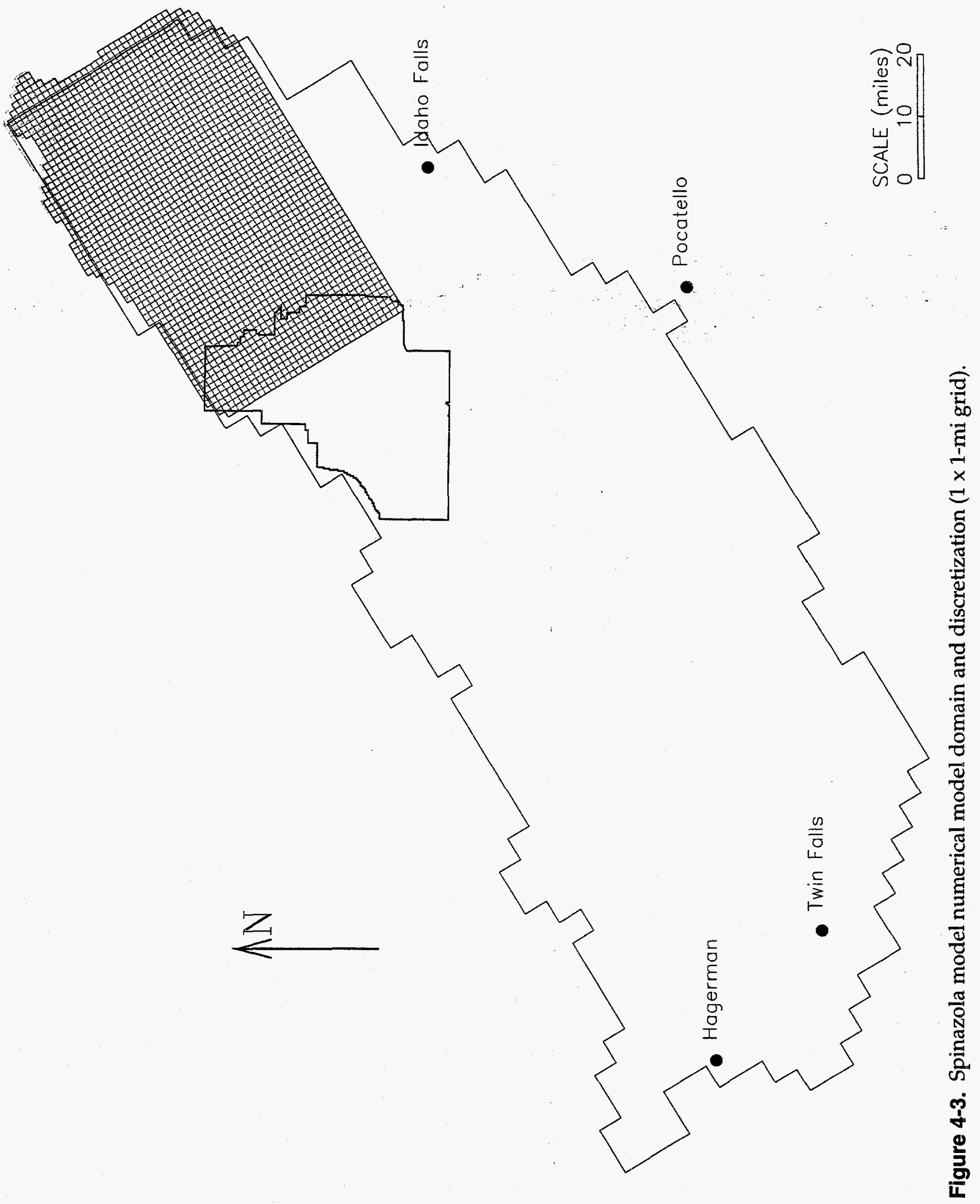




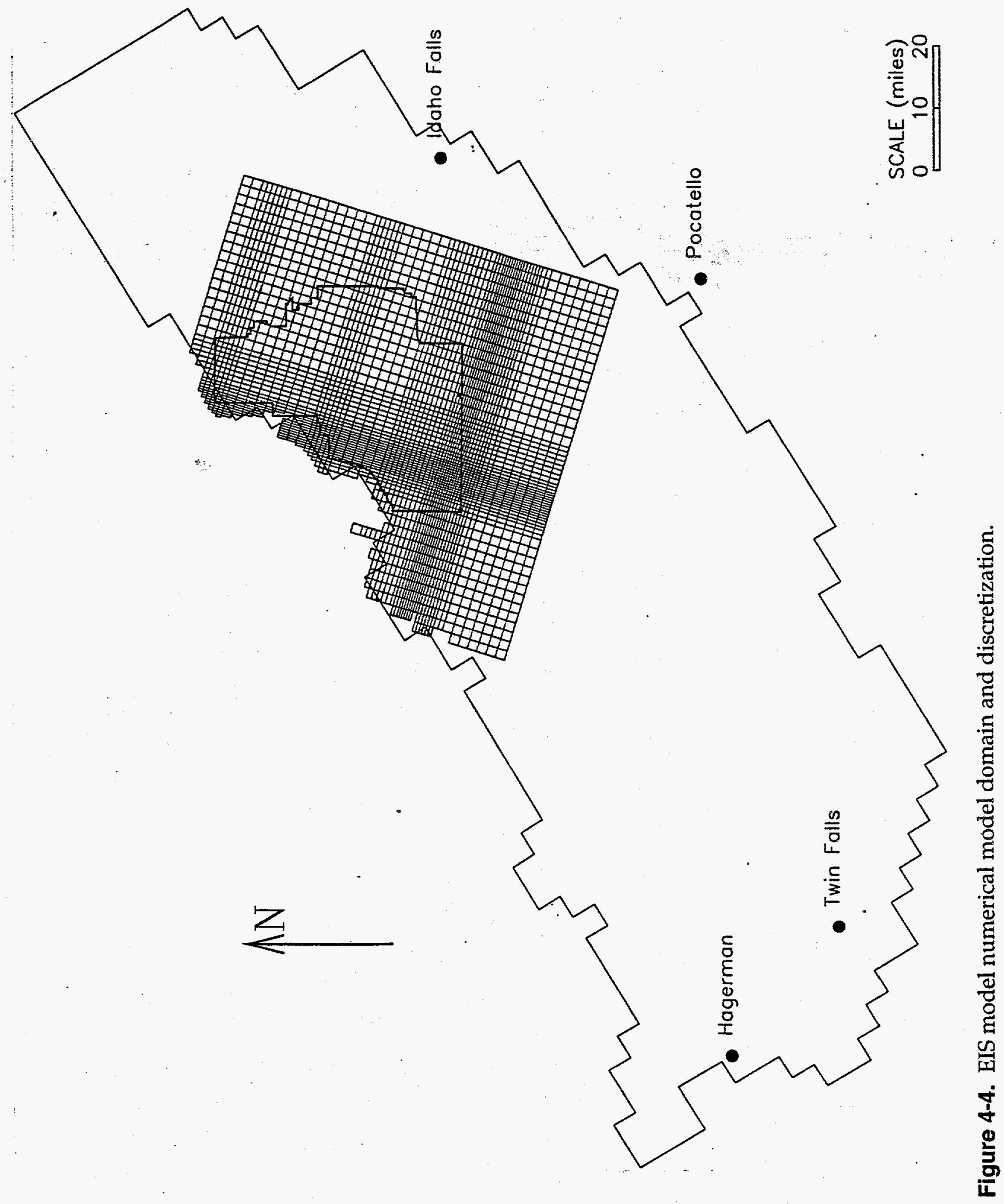




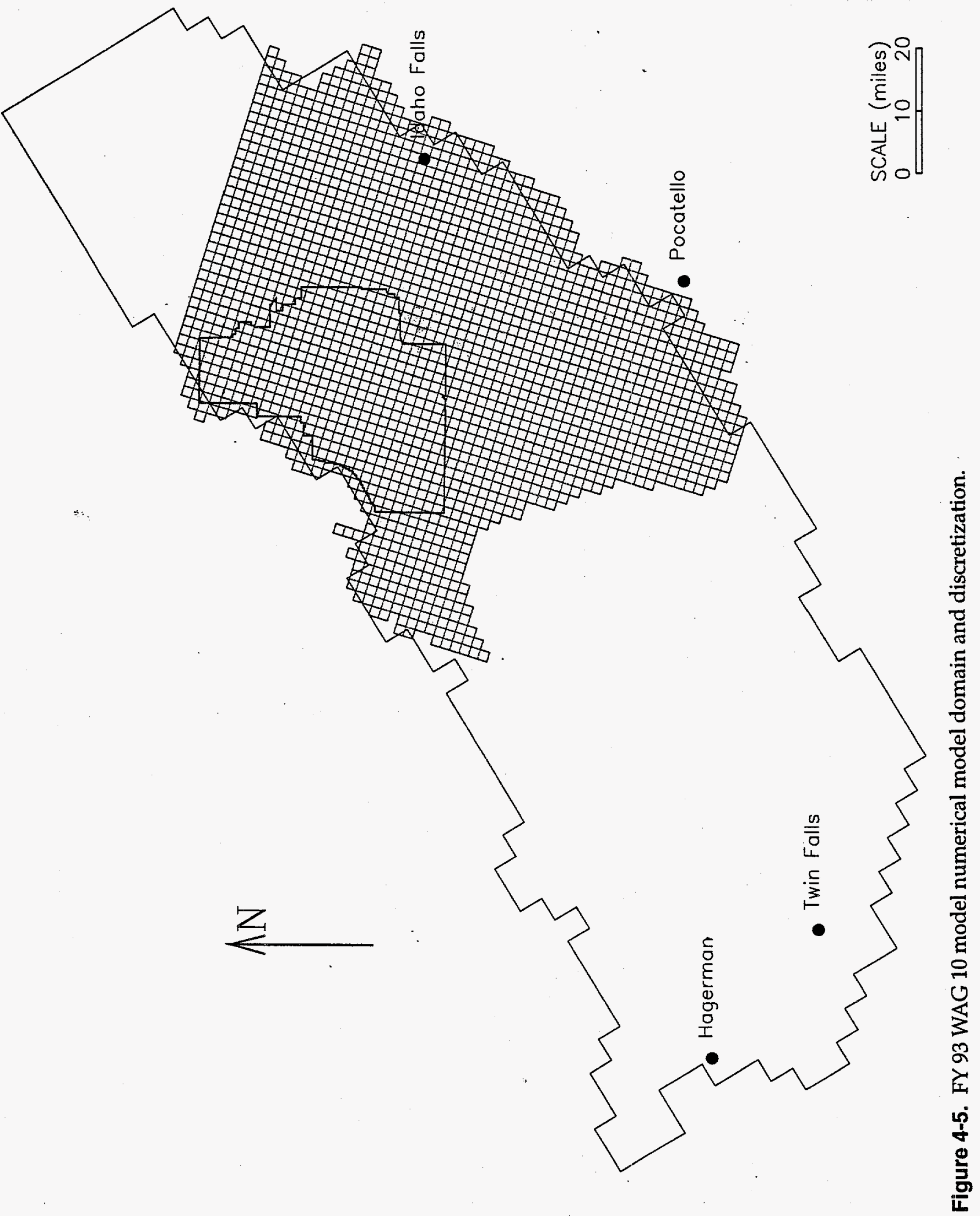




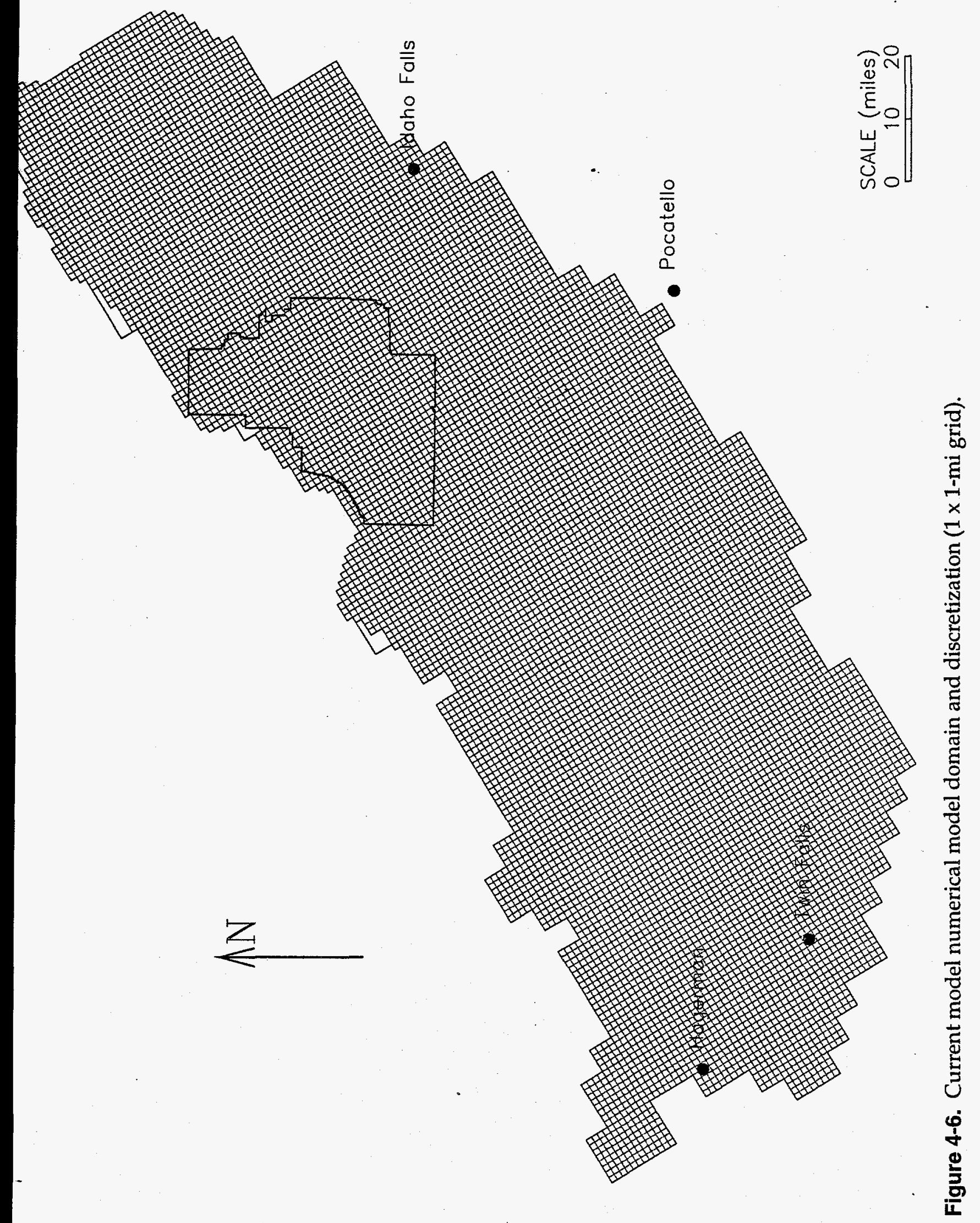


The initial conditions are defined using the binary hydraulic head results from an earlier simulation run (unit 45 defined in the Basic Package input file).

\subsubsection{Output Control Package}

Figure 4-7 is the Output Control input file, which is a set of flags that specify information MODFLOW will print. The flux flag (ICBCFL) in the Output Control Package input file must be set to zero when the sensitivity option is used in the Parameter Estimation Package to print the sensitivity matrices.

\subsubsection{Block Center Flow Package.}

Figure 4-8 is the Block Center Flow input file for the pseudo steady-state (1980) simulation. All four aquifer layers are defined as confined. The cell width along the rows and columns are set to $5,280 \mathrm{ft}$. The transmissivity values are all set to 1 because they are calculated in the Parameter Estimation Package. The vertical conductance divided by the distance between the center of adjacent layers is set to a constant at every grid. The vertical conductance corresponds to the vertical conductances used by Spinazola and correspond to a vertical conductivity of $0.1 \mathrm{ft} /$ day $\left(1.16 \times 10^{-6} \mathrm{ft} / \mathrm{sec}\right)$.

\subsubsection{River Package}

Figure 4-9 is the top and bottom portion of the River Package input file for the pseudo steady-state (1980) simulation. This file modifies the Garabedian River file. The ESRP domain map shown in Garabedian (1992) (Plate 4), was scanned electronically and the Snake River, Henry's Fork, and Portneuf River were digitized to define the rivers' location within the domain with the $1 \times 1 \mathrm{mi}$. The conductances used by Garabedian were modified for the river grids defined for the current model. The Snake River stage and bottom elevations were estimated from the elevations available for the river gauging stations presented in the USGS annual water data reports. The river file is assumed to remain constant for the transient runs.

\subsubsection{Recharge Package}

Figure 4:-10 is the top and bottom portion of the Recharge Package input file for the pseudo steady-state (1980) simulation. The value of each recharge is made up of three pieces:

(1) recharge from direct precipitation,

(2) surface water irrigation in excess of evapotranspiration, and

(3) evapotranspiration of irrigation water from groundwater. The file combines recharge estimates by Garabedian and Spinazola. Because Garabedian grids are $4 \times 4 \mathrm{mi}$, each available grid was separated into $161 \times 1-\mathrm{mi}$ grids of uniform recharge. Spinazola area recharge is incorporated with no changes.

The recharge values used by MODFLOW must be in velocity units (feet per second). The units of the numbers in the third column of the Recharge Package input file are volumetric flux units (cubic feet per second). The numbers are calculated as a recharge rate in feet per second times the area of a Garabedian numerical grid $\left(4 \times 4 \mathrm{mi}\right.$ or $\left.4.46 \times 10^{8} \mathrm{ft}^{2}\right)$. The multiplier of $2.2419 \times 10^{-9}$ on the third line of Figure 4-10 is a factor that converts the volumetric recharge rate to a velocity recharge rate.

\subsubsection{Well Package}

Figure 4-11 is the top and bottom portion of the Well Package input file for the pseudo steady-state (1980) simulation. The value of each discharge or recharge defined in the Well Package input file is potentially made up of three portions: (1) all pumping wells in the grid, (2) any underflow from tributary basins, and (3) leakage from streams or canals that are not defined in the River and Stream Packages. 


$\begin{array}{rrrrc}-1 & -1 & 91 & 92 & \text { IHEDFM, IDDNFM, IHEDUN, IDDNUN } \\ 0 & 1 & 2 & 1 & \text { INCODE, IHDDFL, IBUDFL, ICBCFL } \\ 1 & 0 & 3 & 0 & \text { Hdpr, Ddpr, Hdsv, Ddsv a } 11 \text { layers }\end{array}$

Figure 4-7. Output Control Package input file for the pseudo steady state (1980) simulation.

\begin{tabular}{|c|c|c|c|c|c|c|c|c|}
\hline & 1 & 0 & 12345 . & 0. & & 2 & & \\
\hline \multirow[t]{11}{*}{$\begin{array}{lll}0 & 0 & 0\end{array}$} & 0 & & & & & & & \\
\hline & 0 & 1.0 & & & & & & \\
\hline & 0 & 5280.0 & & & units & feet and seconds & & \\
\hline & 0 & 5280.0 & & $\cdot$ & & & & \\
\hline & 0 & 1.0 & $(15 x, G 15.4)$ & -1 & LOCAT, & CNSTNT, FMTIN, IPRN & Tran & layer 1 \\
\hline & 0 & $5.79 e-9$ & $(15 X, G 15.4)$ & -1 & LOCAT, & CNSTNT, FMTIN, IPRN & Vcont & layer 1-2 \\
\hline & 0 & 1.0 & $(15 x, G 15.4)$ & -1 & LOCAT, & CNSTNT, FMTIN, IPRN & Tran & layer 2 \\
\hline & 0 & $2.89 e-9$ & $(15 x, G 15.4)$ & -1 & LOCAT, & CNSTNT, FMTIN, IPRN & Vcont & layer $2-3$ \\
\hline & 0 & 1.0 & $(15 x, G 15.4)$ & -1 & LOCAT, & CNSTNT, FMTIN, IPRN & Tran & layer 3 \\
\hline & 0 & $1.45 e-9$ & $(15 x, G 15,4)$ & -1 & LOCAT, & CNSTNT, FMTIN, IPRN & Vcont & layer $3-4$ \\
\hline & 0 & 1.0 & $(15 x, G 15,4)$ & -1 & LOCAT, & CNSTNT, FMTIN, IPRN & Tran & layer 4 \\
\hline
\end{tabular}

Figure 4-8. Block Center Flow Package input file. 


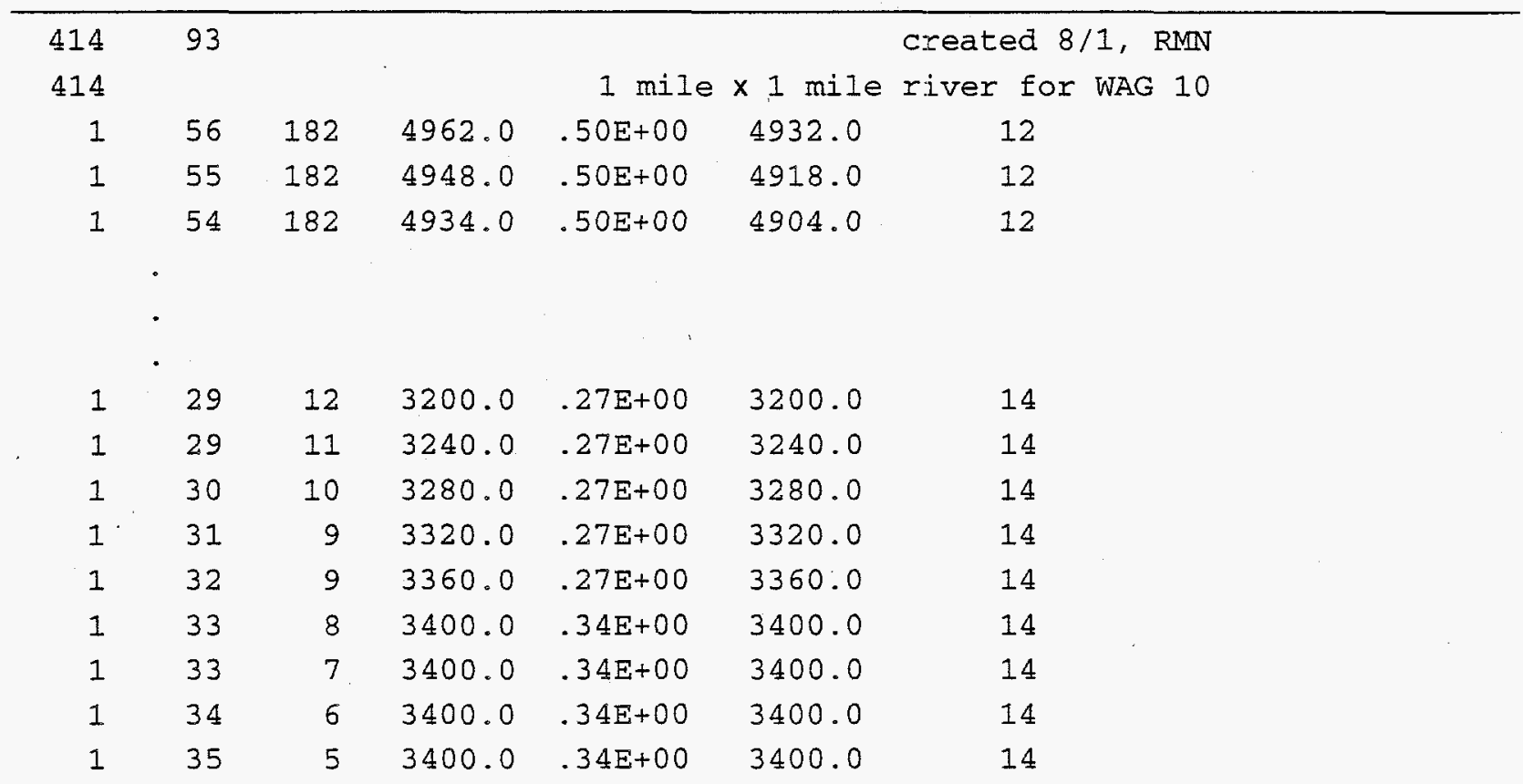

Figure 4-9. River Package input file for the pseudo steady-state (1980) simulation. 


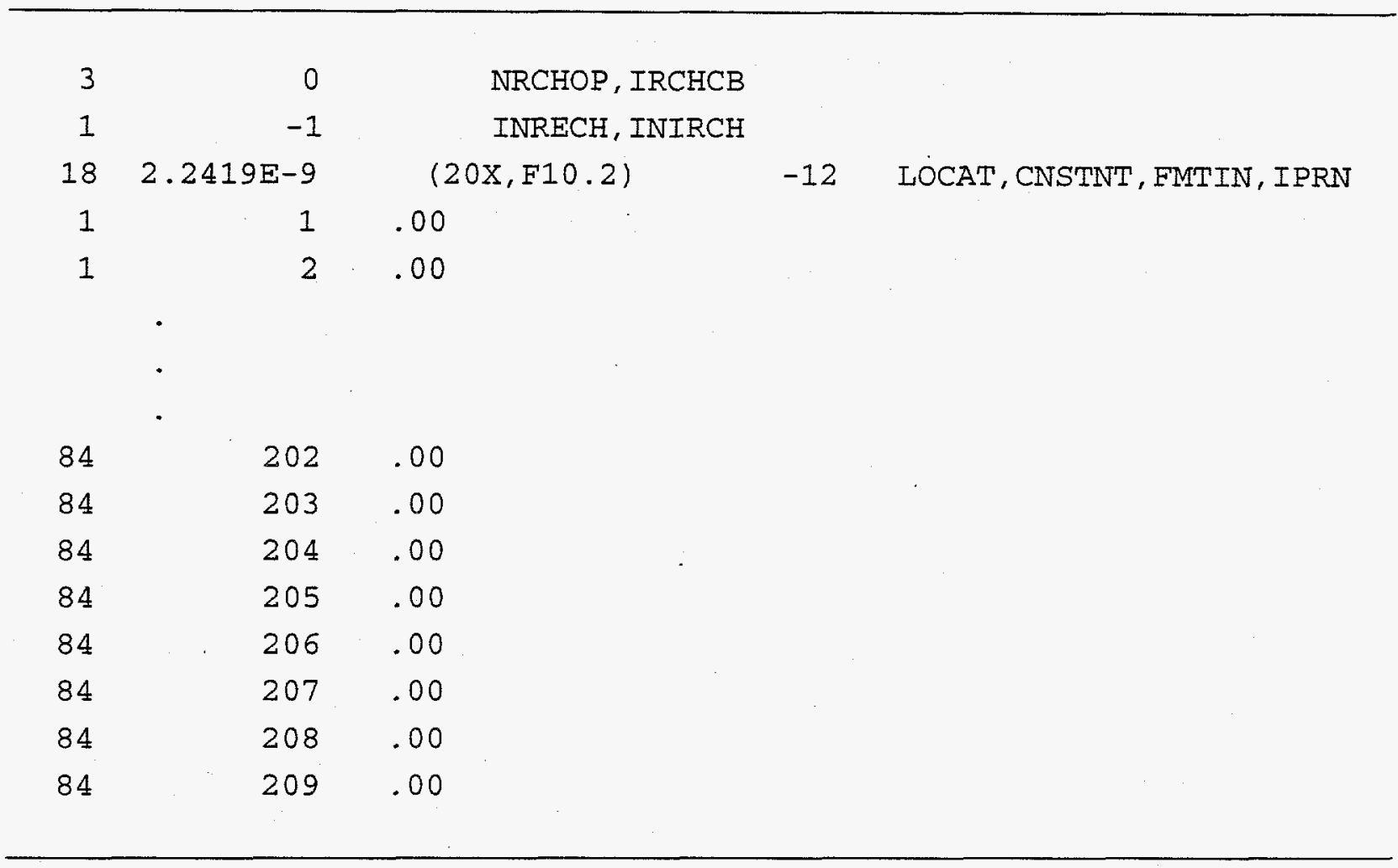

Figure 4-10. Recharge Package input file for the pseudo steady-state (1980) simulation.

\begin{tabular}{|c|c|c|c|c|c|}
\hline 4374 & 0 & & & & \\
\hline 4374 & & & & & \\
\hline 1 & 1 & 9 & -.015625 & & \\
\hline 1 & 1 & 10 & -.015625 & & \\
\hline 1 & 1 & 11 & -.015625 & & \\
\hline 1 & 1 & 12 & -.015625 & & \\
\hline 1 & 1 & 13 & .571429 & CLOVER & CR UNDERFLOW \\
\hline & & & & & \\
\hline & & & & & \\
\hline 2 & 42 & 168 & -.001904 & & OWELLPUMP \\
\hline 3 & 12 & 164 & -.462300 & & OWELLPUMP \\
\hline 3 & 21 & 161 & -.017270 & & OWELLPUMP \\
\hline 3 & 23 & 154 & -.477000 & & OWELLPUMP \\
\hline 3 & 41 & 181 & -.091080 & & OWELLPUMP \\
\hline 3 & 42 & 166 & -.031860 & & OWELLPUMP \\
\hline
\end{tabular}

Figure 4-11. Well Package input file for the pseudo steady-state (1980) simulation. 
The file is a combination of discharge and recharge estimates by Garabedian and Spinazola.

The total underflow estimates from Garabedian are redistributed along the edge of the $1 \times 1-\mathrm{mi}$ domain. All pumping wells and river and canal leakage defined in Garabedian are uniformly distributed over the 16 grids in Garabedian's model. The Spinazola area well information is incorporated with no changes.

The discharge or recharge defined in the Well Package input file has volumetric flux units of cubic feet per second.

\subsubsection{Drain Package}

Figure 4-12 is the Drain Package input file for the pseudo steady-state (1980) simulation. The two drain nodes defined, both in the Spinazola model, are incorporated directly into the model.

\subsubsection{General-Head Package}

Figure $4-13$ is the General-Head Package input file for the pseudo steady-state (1980) simulation. This input file defines the underflow boundary condition for the Big Lost River, Little Lost River, and Birch Creek for the transient runs. This input file is used to define the annual fluctuations in underflow along the tributary drainage basins.

\subsubsection{Preconditioned Conjugate Gradient Package}

Figure 4-14 is the Preconditioned Conjugate Gradient Package (Hill 1990) input file. This package is an alternative matrix solver to the standard SIP solver provided with MODFLOW. It is the recommended solver when using MODFLOWP for parameter estimation.

\subsubsection{Stream Package}

Figure 4-15 is the top and bottom of the Stream Package input file for the pseudo steady-state (1980) simulation. The Stream Package is only used for simulating flow in Medicine Lodge Creek, Beaver Creek, Camas Creek, and Wood's diversion. The Stream Package input file for these streams was defined by Spinazola and is incorporated directly into the current model.

\subsection{MODFLOWP Input}

\section{The MODFLOWP Parameter Estimation} Package has a complicated input structure. Therefore, rather than providing great detail, this section generally describes how parameters (primarily K) and observations used for model calibration are defined and refers to portions of the parameter input file that are important to this study. Fourteen data sets define different portions of the input file. Because of the complexity of the package, the MODFLOWP manual must be studied to understand the input files and to obtain detailed information about each data set. A complete copy of the Parameter Estimation Package input file for the steady-state calibration run is included in Appendix A.

MODFLOWP can be used to make simulation, sensitivity analysis, or parameter estimation model runs. It can use estimates of most parameters in the flow model. For the sensitivity analysis model runs, wells defining the underflow from tributary basins and river conductance are incorporated as parameters. The parameter discussion in this section is limited to hydraulic conductivity $(K)$ because it is the primary parameter of interest for this study. This section discusses (a) defining the $K$, (b) defining the hydraulic head observation calibration set, (c) integrating previous models' $\mathrm{K}$ into the current model, and (d) identifying major inconsistencies between MODFLOW and MODFLOWP. 


$\begin{array}{llllll}2 & -1 & & & & \\ 2 & -1 & & & & \\ 1 & 26 & 167 & 4764 & 1.0675 & 4769 . \\ 1 & 27 & 168 & 4757 & 1.5510 & 4762 .\end{array}$

Figure 4-12. Drain Package input file for the pseudo steady-state (1980) simulation.

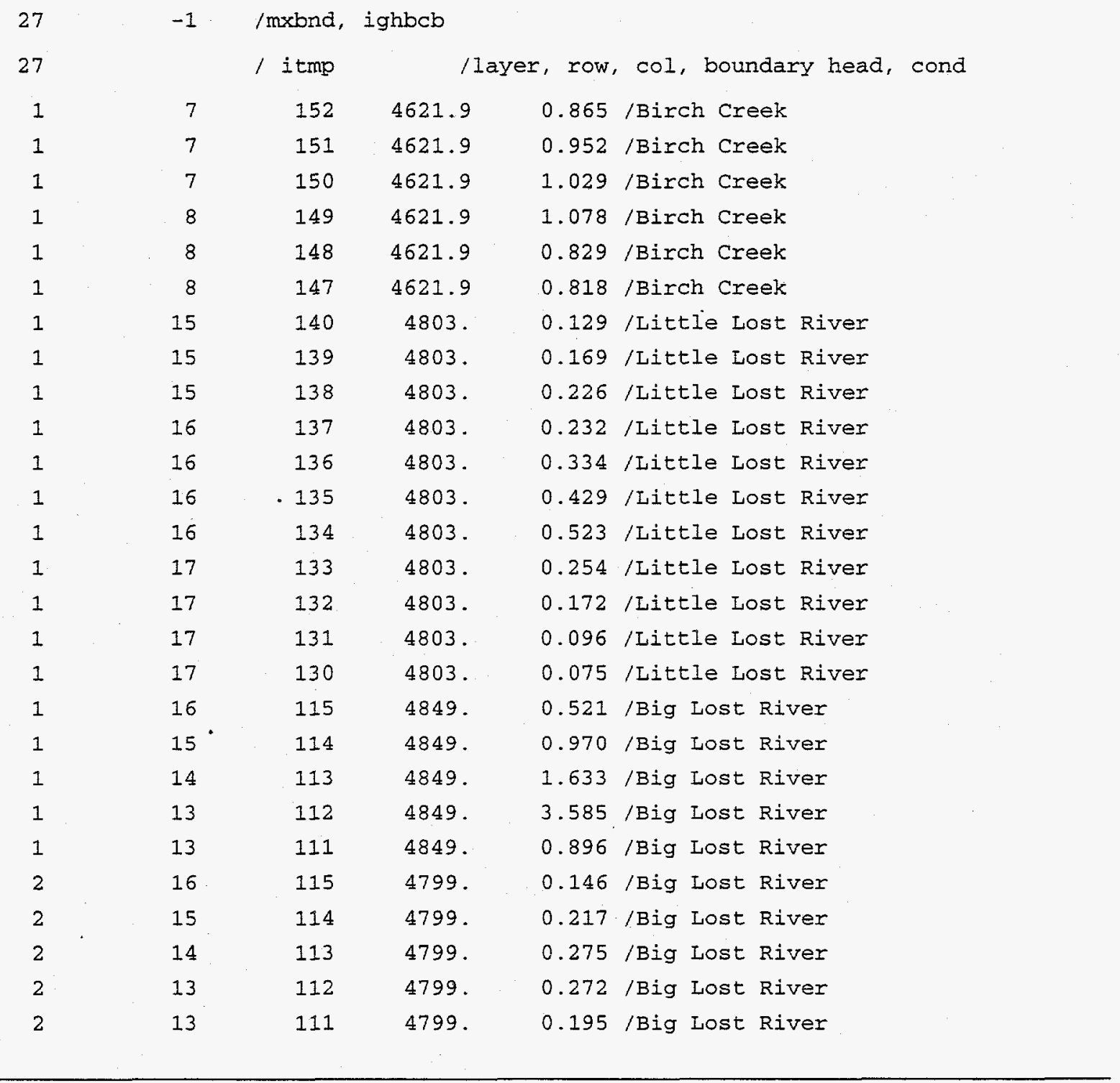

Figure 4-13. General-Head Package input file for the pseudo steady-state (1980) simulation. 

50
$1 . e-01$
50
$1 . e-01$
$0.9 \frac{1}{5}$
2
0
0
0

Figure 4-14. Preconditioned Conjugate Gradient Package input file.

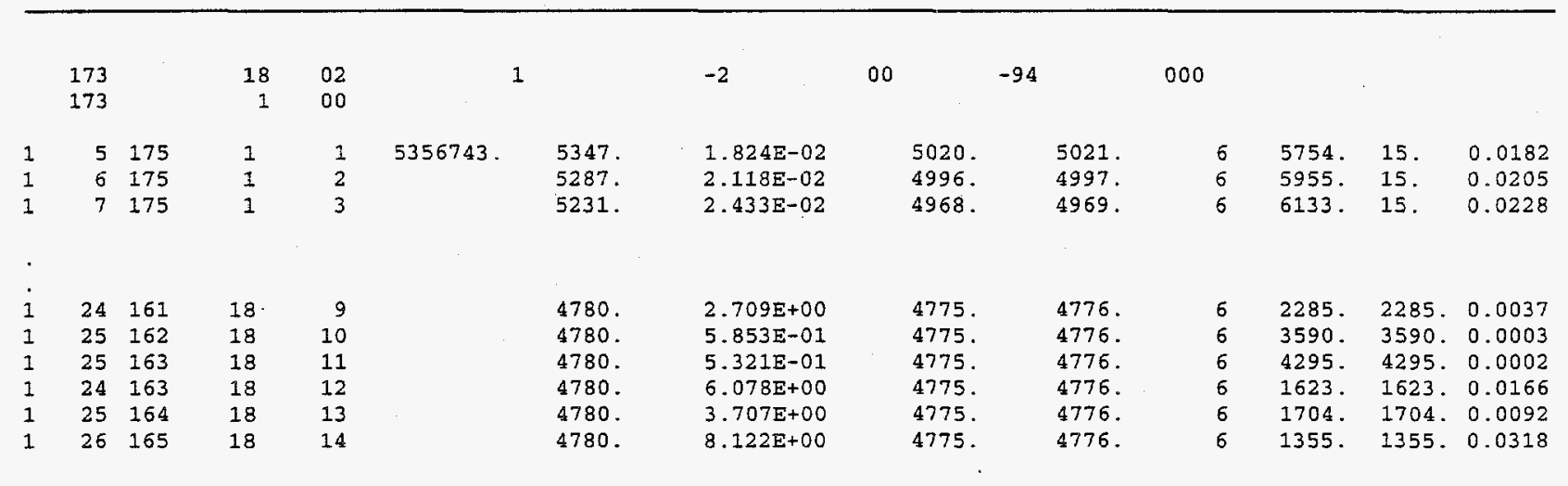

Figure 4-15. Stream Package input file for the pseudo steady-state (1980) simulation. 


\subsubsection{Hydraulic Conductivity Parameter Definition}

Hydraulic conductivity parameters and the aquifer layers they apply to are defined in Data Set 2 of the Parameter Estimation Package input. For each $\mathrm{K}$ parameter defined in Data Set 2 and in each layer it is defined, information is given in Data Set $2 b$, which specifies (a) a scalar multiplier, (b) a multiplication array for multiplying the parameter value by different factors for each grid location, (c) a flag array that defines which numerical grids are assigned to different $\mathrm{K}$ zones, and (d) a list of the $\mathrm{K}$ zones to be defined by the value assigned to the parameter.

The K parameter definitions in Data Sets 2 and $2 \mathrm{~b}$ calculate the transmissivity at each numerical grid block. Figure 4-16 shows a portion of Data Sets 2 and $2 b$ as an example of how the information in the Parameter Estimation Package input is used to generate transmissivity values for use in MODFLOW (line numbers have been added to the first parameter to explain the data set). Three parameters define the parameter " $\mathrm{T}$," which is the MODFLOWP flag for the transmissivity or $\mathrm{K}$ parameter. One $\mathrm{K}$ value is assigned to each of the three parameters in the example. The information included in Data Sets 2 and $2 b$ is used to generate transmissivity values for every grid defined within these zones.

The numbers 1, 2,3, and 4 in Data Set 2 mean that all three parameters are defined for all four numerical model layers. There is one row in Data Set $2 b$ for each layer that is defined for that parameter. The numbers in Data Set $2 \mathrm{~b}$ represent the following:

1. The first column of numbers in lines 14 of Data Set $2 b$ are scalar multipliers for the $\mathrm{K}$ value assigned to that parameter in layers $1-4$. Therefore, the $\mathrm{K}$ value for a grid defined by any of these three parameters is multiplied by 1.0 for grids in layers 1 and 2, by 0.67 for grids in layer 3 , and by 0.33 for grids in layer 4 .

2. The second column of numbers in lines 1-4 of Data Set $2 b$ are flags that define which multiplication matrices (Data Set 3) should be used to modify the $K$ value for each grid within a parameter zone. For this model, the Data Set 3 matrices are used to define the thickness of each aquifer layer. Therefore, multiplication matrix \#1 (line 1) is a matrix of all 200 because the thickness of layer 1 is $200 \mathrm{ft}$ at all grids, multiplication matrix \#2 (line 2) is a matrix of all 300 because the thickness of layer 2 is $300 \mathrm{ft}$ at all grids, multiplication matrix \#3 (line 3) varies from 0 to 500 depending on the thickness assigned to each grid in layer 3 , and multiplication matrix \#4 (line 4) varies from 0 to 3,000 depending on the thickness assigned to each grid in layer 4.

3. The third column of numbers are flags that define which zone array (Data Set 4) is used to define the K zones for that layer. In this case, the zone array flag is one for all four layers because the $\mathrm{K}$ zones are defined as the same in all four layers.

4. All fourth and additional columns define which $\mathrm{K}$ zones from the zone array should be assigned the parameter value. Therefore, parameter number 1 defines the $K$ value of all numerical grids that fall in zone 51 , parameter number 2 defines the $K$ value of all numerical grids that fall in zone 53 , and parameter number 3 defines the $K$ value of all numerical grids that fall in zone 55 . 


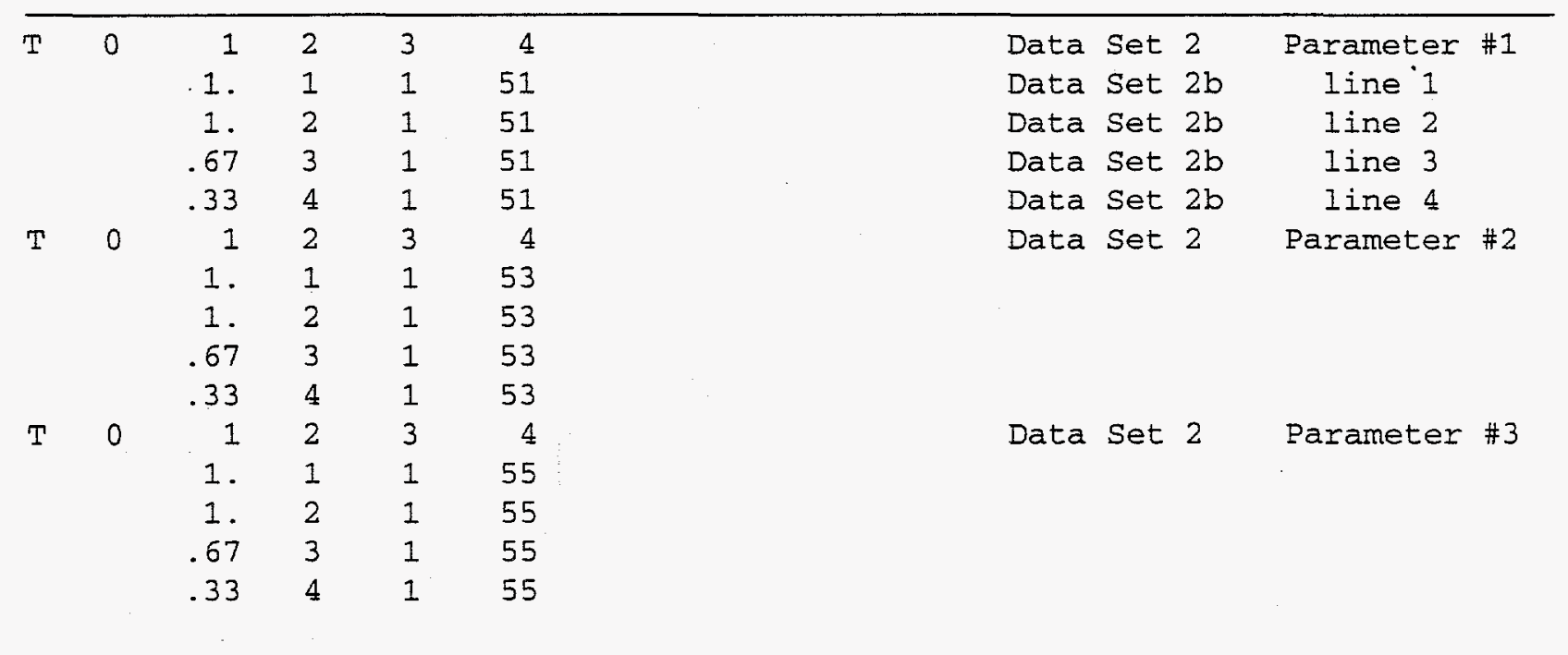

Figure 4-16. Top portion of Data Set 2 of the example Parameter Estimation Package input file. 
The transmissivity value at a numerical grid (layer $=\mathrm{L}$, row $=\mathrm{J}, \mathrm{col}=\mathrm{I}$ ) is calculated by finding the $\mathrm{K}$ value (Data Set 8 ) for the parameter that is assigned to the $\mathrm{K}$ zone flag for grid ( $\mathrm{L}, \mathrm{J}, \mathrm{I})$, multiplying it by the scalar multiplication factor appropriate for layer $\mathrm{L}$, and multiplying that by the value in location $(J, I)$ in the multiplication matrix flagged for layer $\mathrm{L}$ in Data Set $2 b$. The MODFLOWP procedure for defining a transmissivity value is more versatile than the MODFLOW procedure.

\subsubsection{Hydraulic Head Observations for Calibration}

Figure 4-17 shows the hydraulic head observations defined in Data Set 6 of the Parameter Estimation Package input file. The columns of the input file represent (1) well name identifier, (2) layer, (3) row, (4) column, (5) time step, (6) row offset, (7) column offset, (8) time step offset, (9) observed hydraulic head, (10) value from which the weight of the observed head is calculated, (11) flag indicating how the weight is to be used, and (12) full name of the well (not used by MODFLOWP).

The row, column, and time step offsets are used to interpolate the calculated hydraulic head to the actual location in time and space of the observation. This is particularly important when calibrating a regional model where the numerical grids may be very large with respect to the distance between observation wells so the hydraulic head at the center of the numerical grid may be quite different than at the edge of the numerical grid (MODFLOW only calculates hydraulic head at the center).

A large number in column 10 applies a small weight to that observation. For the Figure 4-17 example, the weight for well anp-07 is 100 , and the weight for well arbor-test is 1. Therefore, an error between the observed and calculated hydraulic head.at well anp-07 is weighted one tenth $\left(100^{-0.5}\right)$ as strongly as an observation at well arbor-test.

\subsubsection{Integrating Previous Models Hydraulic Conductivity Zones}

To integrate $\mathrm{K}$ zones from the Garabedian, Spinazola, FY 93 WAG 10, and EIS models, K and thickness values are assigned that represent the transmissivity values used by Garabedian and Spinazola.

Table 4-1 provides the layer thicknesses used in the four models. The current model combines the layers by (a) using the Garabedian four-layer model and (b) combining Spinazola's top two layers into a new layer $200 \mathrm{ft}$ thick.

Layers 3 and 4 have variable thicknesses as defined in Garabedian and Spinazola, but the data are not divided into hydraulic conductivity and thickness information. Therefore, the layer thicknesses for layers 3 and 4 were estimated using the maps for the rock distribution on Plate 4 in Garabedian (1992).

Hydraulic conductivity values for each grid in the domain were calculated from the transmissivity values available in Garabedian and Spinazola's MODFLOW input files and the layer thickness estimates. An average $\mathrm{K}$ value was calculated for each layer, for each transmissivity zone defined in layer 1 of Garabedian (1992), and estimated from Spinazola (1994). (The current model refers to the zones as $\mathrm{K}$ zones because constant $\mathrm{K}$ values are defined for each zone, not constant transmissivity values.)

Multiplication factors were calculated for each of layers 2,3, and 4 so that the $K$ value in those layers could be defined as the $K$ value in layer 1 times a factor. The fraction is used in Data Set $2 b$ to define the $K$ value in layers 2,3 , 


\begin{tabular}{|c|c|c|c|c|c|c|c|c|c|c|c|}
\hline arbt & 1 & 37 & 141 & 0 & 0.28 & -0.07 & 0.00 & 4486.7 & 1. & 0 & arbor-test \\
\hline anp7 & 1 & 15 & 149 & 0 & -0.06 & -0.05 & 0.00 & 4582.8 & 100. & 0 & anp-07 \\
\hline anp9 & 1 & 23 & 148 & 0 & 0.26 & 0.41 & 0.00 & 4565.3 & 100. & 0 & anp-09 \\
\hline arco & 1 & 14 & 113 & 0 & 0.50 & 0.50 & 0.00 & 4799.4 & 4. & 0 & arco-test \\
\hline $\operatorname{arII}$ & 1 & 36 & 133 & 0 & 0.35 & 0.39 & 0.00 & 4461.0 & 3. & 0 & area-II \\
\hline$c r-g$ & 1 & 38 & 123 & 0 & 0.36 & 0.38 & 0.00 & 4426.2 & 2 . & 0 & cerro-g \\
\hline$h-2$ & 1 & 43 & 146 & 0 & 0.13 & -0.04 & 0.00 & 4494.4 & 3. & 0 & hwy -2 \\
\hline mtrt & 1 & 29 & 128 & 0 & -0.15 & -0.24 & 0.00 & 4459.3 & 1. & 0 & mtr-test \\
\hline$p \& w 2$ & 1 & 16 & 148 & 0 & -0.43 & -0.22 & 0.00 & 4580.8 & 100. & 0 & $p \& w-2$ \\
\hline smp1 & 1 & 17 & 136 & 0 & -0.29 & -0.49 & 0.00 & 4684.6 & 3. & 0 & simplot-1 \\
\hline$s-09$ & 1 & 35 & 129 & 0 & -0.31 & -0.47 & 0.00 & 4454.4 & 1. & 0 & site-09 \\
\hline$s-14$ & 1 & 26 & 141 & 0 & -0.36 & -0.45 & 0.00 & 4526.0 & 2. & 0 & site-14 \\
\hline u001 & 1 & 42 & 130 & 0 & -0.43 & 0.06 & 0.00 & 4435.5 & 2. & 0 & usgs -001 \\
\hline u002 & 1 & 37 & 137 & 0 & 0.04 & -0.42 & 0.00 & 4468.7 & 1. & 0 & usgs -002 \\
\hline u004 & 1 & 30 & 155 & 0 & 0.32 & 0.47 & 0.00 & 4533.6 & 3. & 0 & usgs -004 \\
\hline u005 & 1 & 32 & 134 & 0 & -0.06 & -0.43 & 0.00 & 4471.2 & 2. & 0 & usgs -005 \\
\hline u006 & 1 & 29 & 139 & 0 & 0.04 & 0.36 & 0.00 & 4486.3 & 2 & 0 & usgs -006 \\
\hline u007 & 1 & 21 & 145 & 0 & -0.09 & 0.30 & 0.00 & 4578.4 & 100 & 0 & usgs -007 \\
\hline 4008 & 1 & 26 & 115 & 0 & 0.32 & 0.07 & 0.00 & 4430.1 & 3. & 0 & usgs -008 \\
\hline u009 & 1 & 33 & 118. & 0 & 0.11 & -0.07 & 0.00 & 4425.2 & 1. & 0 & usgs-009 \\
\hline u011 & 1 & 36 & 114 & 0 & 0.21 & 0.06 & 0.00 & 4415.1 & 3. & 0 & usgs -011 \\
\hline u012 & 1 & 24 & 133 & 0 & -0.06 & 0.15 & 0.00 & 4491.9 & 1. & 0 & usgs -012 \\
\hline u013 & 1 & 29 & 111 & 0 & -0.15 & -0.19 & 0.00 & 4388.4 & 3. & 0 & usgs -013 \\
\hline u014 & 1 & 44 & 119 & 0 & 0.03 & 0.24 & 0.00 & 4417.8 & 3. & 0 & usgs -014 \\
\hline u017. & 1 & 27 & 134 & 0 & 0.13 & 0.33 & 0.00 & 4479.8 & 1. & 0 & usgs -017 \\
\hline u018 & 1 & 25 & 143 & 0 & -0.37 & 0.50 & 0.00 & 4535.4 & 200 & 0 & usgs -018 \\
\hline u019 & 1 & 20 & 133 & 0 & -0.24 & -0.03 & 0.00 & 4526.9 & 3 & 0 & usgs -019 \\
\hline u020 & 1 & 32 & 128 & 0 & 0.35 & 0.05 & 0.00 & 4456.0 & 1. & 0 & usgs-020 \\
\hline u021 & 1 & 30 & 146 & 0 & -0.36 & 0.01 & 0.00 & 4508.4 & 2. & 0 & usgs -021 \\
\hline u022 & 1 & 27 & 123 & 0 & 0.21 & 0.07 & 0.00 & 4439.5 & 2. & 0 & usgs -022 \\
\hline uo23 & 1 & 22 & 129 & 0 & 0.29 & 0.39 & 0.00 & 4485.7 & 2. & 0 & usgs -023 \\
\hline น026 & 1 & 20 & 151 & 0 & 0.23 & -0.39 & 0.00 & 4581.6 & 1. & 0 & usgs -026 \\
\hline u 027 & 1 & 27 & 154 & 0 & -0.29 & -0.17 & 0.00 & 4561.4 & 300. & 0 & usgs -027 \\
\hline L029 & 1 & 33 & 153 & 0 & -0.14 & 0.43 & 0.00 & 4527.7 & 3. & 0 & usgs-029 \\
\hline $430 \mathrm{c}$ & 1 & 30 & 152 & 0 & -0.34 & 0.40 & 0.00 & 4528.6 & 3. & 0 & usgs $-030 \mathrm{c}$ \\
\hline 4039 & 1 & 31 & 127 & 0 & -0.37 & 0.11 & 0.00 & 4458.0 & 1. & 0 & usgs - 039 \\
\hline 4040 & 1 & 31 & 128 & 0 & -0.47 & -0.02 & 0.00 & 4458.6 & 1. & 0 & usgs -040 \\
\hline 4076 & 1 & 30 & 127 & 0 & -0.28 & 0.17 & 0.00 & 4458.7 & 1. & 0 & usgs -076 \\
\hline uo77 & 1 & 32 & 128 & 0 & -0.49 & -0.49 & 0.00 & 4457.3 & 1. & 0 & usgs -077 \\
\hline u079 & 1 & 29 & 127 & 0 & -0.28 & 0.02 & 0.00 & 4459.0 & 1. & 0 & usgs -079 \\
\hline u086 & 1 & 30 & 117 & 0 & -0.21 & -0.21 & 0.00 & 4428.7 & 3. & 0 & usgs -086 \\
\hline u 087 & 1 & 32 & 121 & 0 & -0.47 & -0.07 & 0.00 & 4429.8 & 1. & 0 & usgs -087 \\
\hline u089 & 1 & 31 & 120 & 0 & 0.28 & 0.28 & 0.00 & 4429.5 & 1. & 0 & usgs-089 \\
\hline u097 & 1 & 27 & 131 & 0 & 0.12 & 0.04 & 0.00 & 4479.4 & 1. & 0 & usgs -097 \\
\hline u101 & 1 & 40 & 140 & 0 & -0.48 & -0.33 & 0.00 & 4483.3 & 1. & 0 & usgs -101 \\
\hline u105 & 1 & 36 & 121 & 0 & -0.32 & -0.28 & 0.00 & 4426.8 & 2. & 0 & usgs-105 \\
\hline u106 & 1 & 33 & 123 & 0 & 0.18 & .0 .05 & 0.00 & 4449.5 & 2 . & 0 & usgs -106 \\
\hline u107 & 1 & 36 & 127 & 0 & 0.13 & 0.20 & 0.00 & 4440.3 & 2. & 0 & usgs -107 \\
\hline
\end{tabular}

Figure 4-17. Hydraulic head observations defined in Data Set 6 of the Parameter Estimation Package input file. This file was used for the transient simulations. 
Table 4-1. Model layer thicknesses.

\begin{tabular}{lcl}
\hline \multicolumn{1}{c}{ Model } & Number of layers & \multicolumn{1}{c}{$\begin{array}{c}\text { Layer thicknesses } \\
(\mathrm{ft})\end{array}$} \\
\hline Garabedian & 4 & $200,300,0-500,0-3,000$ \\
Spinazola & 5 & $100,100,300,0-500,0-1,000$ \\
FY 93 WAG 10 & 1 & 250 \\
EIS & 1 & 330 \\
Current & 4 & $200,300,0-500,0-3,000$ \\
\hline
\end{tabular}


and 4 . In the vicinity of the INEL where new zones were defined, it is assumed that the layer 1 and layer $2 \mathrm{~K}$ values are the same, the layer 3 value is $2 / 3$ of the layer 1 value, and the layer 4 value is $1 / 3$ of the layer 1 value (following the assumption of decreasing $\mathrm{K}$ with depth made by both the Garabedian and Spinazola models).

The K zones for the different models were integrated by (a) refining the $4 \times 4-\mathrm{mi}$ Garabedian model to $1 \times 1$-mi grids, (b) superimposing the K zones from the Spinazola model in the Mud Lake area and new $\mathrm{K}$ zones in the vicinity of the INEL, and (c) superimposing new $\mathrm{K}$ zones in the vicinity of the INEL that were defined during the course of the current model calibration. The INEL area $\mathrm{K}$ zones are based in part on the FY 93 WAG 10 and EIS models as well as the Test Area North groundwater modeling (SchaferPerini 1993).

\subsubsection{Major Inconsistencies Between MODFLOW and MODFLOWP}

This study identified a major inconsistency between MODFLOW and MODFLOWP. MODFLOW allows multiple pumping or recharge wells to be defined with the Well Package and MODFLOWP does not.

Therefore, MODFLOWP forces the modeler to combine all sources and sinks in each grid that are defined with the well package.

Garabedian and Spinazola each use the Well Package to define pumping, tributary basin underflow, and leakage from tributaries basins. These different water budget components are flagged in the Well Package input file. When the well file is incorporated into the Parameter Estimation input file, the detail is lost for all grids that have more than one water budget component. 


\section{MODEL CALIBRATION}

This modeling study provides a tool for defining the regional hydraulic setting that may be used to support local-scale groundwater transport modeling that may be performed for WAGs 1 through 9. The flow velocity is the primary parameter of importance; therefore, head gradient as well as head calibration targets were used. Key wells were chosen within the INEL to be the primary locations for the calibration to ensure the simulation model adequately reproduced the gradients and flow direction through each of the nine facility-specific WAG areas (see Figure 5-1). Key wells were selected based on the following criteria:

1. Relative spacing with respect to the WAG locations and other well locations

2. Number of water level measurements for the spring of 1980 (for the pseudo steady-state model) and 1980 through 1990 (transient model)

3. Fairly uniform well completion for all the key wells

4. Wells with some transient response, particularly near areas of significant infiltration such as the Big Lost River and spreading areas.

To calculate the hydraulic gradient and flow direction for each well, three key wells were originally planned for each WAG. In the process of choosing the key wells, the complexity of the hydraulic head distribution in the northern portion of the INEL required more than three key wells, and the close proximity of WAGs 2 through 8 (Figure 5-1) made it possible to identify one key well for several different WAGs. In addition, during the calibration process it was found that the gradient could not be adequately simulated with the regional scale model using three wells close to a WAG ( 1 to $10 \mathrm{mi}$ apart). The gradient can be adequately simulated on a larger (intermediate) scale. The gradients were evaluated for this calibration on the intermediate scale. Therefore, 21 key wells were chosen: 4 wells in the vicinity of WAG 1 , 3 wells in the vicinity of WAG 9, and 14 wells in the vicinity of WAGs 2 through 8 . Table 5-1 shows the key wells chosen for the calibration.

Table 5-1. Twenty-one key wells and corresponding WAGs.

\begin{tabular}{|c|c|}
\hline WAG & Well name \\
\hline 1 & anp-9 \\
\hline 1 & $p \& w-2$ \\
\hline 1 & usgs-007 \\
\hline 1 & usgs-026 \\
\hline 9 & arbor-test \\
\hline 9 & usgs-002 \\
\hline 9 & usgs-101 \\
\hline $2-8$ & mtr-test \\
\hline $2-8$ & site-09 \\
\hline $2-8$ & usgs-009 \\
\hline $2-8$ & usgs-012 \\
\hline $2-8$ & usgs-017 \\
\hline $2-8$ & usgs-020 \\
\hline $2-8$ & usgs-039 \\
\hline $2-8$ & usgs-040 \\
\hline $2-8$ & usgs -076 \\
\hline $2-8$ & usgs-077 \\
\hline $2-8$ & usgs-079 \\
\hline $2-8$ & usgs-087 \\
\hline $2-8$ & usgs-089 \\
\hline $2-8$ & usgs-097 \\
\hline
\end{tabular}




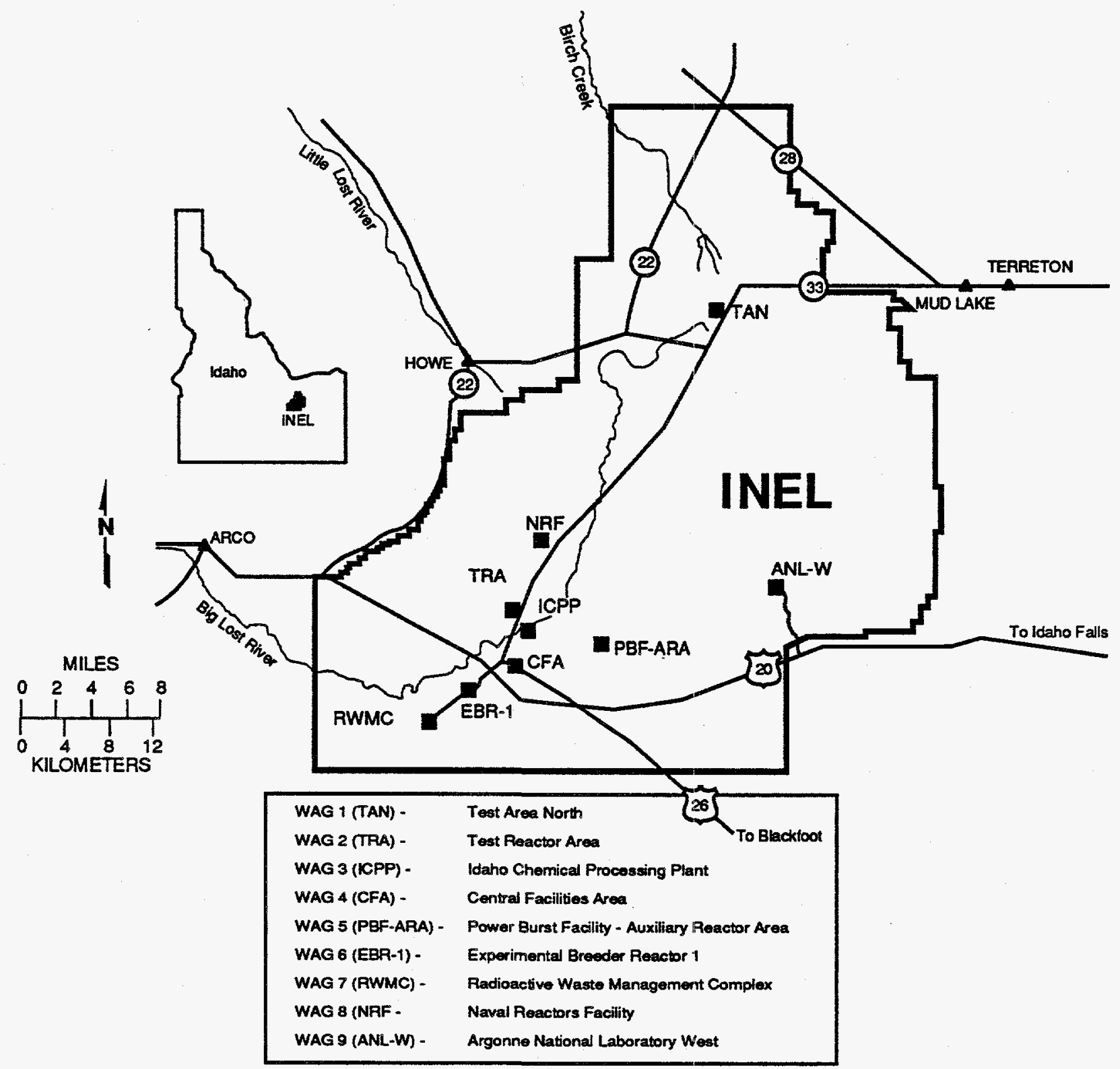

Figure 5-1. INEL map and WAG locations. 
The groundwater model flow calibration focuses on defining zones of constant $\mathrm{K}$ within the domain and estimating appropriate $\mathrm{K}$ values that allow the simulation model to reproduce the measured 1980 hydraulic head values at the 21 key observation wells. While 48 wells distributed over the area of the INEL were used to perform the calibration, the calibration focuses on the 21 key wells and using the results of the calibration runs to modify $\mathrm{K}$ zones and values to improve the calibration.

\subsection{Calibration Process}

This section discusses the (a) systematic parameter estimation approach that MODFLOWP is designed to perform, (b) specifics of the parameter estimation approach used in this study, and

(c) calibration targets defined for this study. Although the calibration targets have not all been satisfied, the targets focus the modeling effort on the modeling objectives.

\subsubsection{General Calibration Approach Using MODFLOWP}

A nine-step general calibration approach using MODFLOWP is as follows:

1. Define calibration targets for the numerical model. The calibration targets set for this study are described in Section 5.1.3.

2. Identify key observation wells and/or flux points to be used to calibrate the model. Collect all of the available hydraulic head measurements (observations) and flux information that are appropriate for use in calibrating the flow model.

3. Divide the numerical grid into zones of equal $\mathrm{K}$. Each $\mathrm{K}$ zone is defined by a different parameter with a constant model parameter value.
4. Make initial estimates for the $\mathrm{K}$ values for each zone.

5. Use MODFLOWP to simulate hydraulic head values at each numerical grid in the domain and at each point that corresponds to locations of available hydraulic head measurements. Weighted differences between the measured hydraulic heads and the simulated hydraulic heads are the prediction errors (or residuals). The weights assigned to each observation depend on the modelers' confidence in the observation and the importance of the observation to the calibration objective. The calibration objective of MODFLOWP is to find values for each $\mathrm{K}$ zone such that the weighted sum of the squared simulation errors (residuals) is minimized. This objective is called the performance measure for the model.

6. Use MODFLOWP to calculate the sensitivity of the simulated hydraulic head (at each location where there is a measured hydraulic head) to the $\mathrm{K}$ value in each $\mathrm{K}$ zone. The hydraulic head sensitivity at a particular location to the $\mathrm{K}$ value in $\mathrm{K}$ zone $\mathrm{i}$ is defined as the change in the simulated hydraulic head at that location per unit change in the value of $\mathrm{K}$ zone $\mathrm{i}$. This provides a sensitivity map for each $\mathrm{K}$ zone.

7. Use MODFLOWP to automatically adjust the $\mathrm{K}$ value of a selected set of $\mathrm{K}$ zones to minimize the weighted sum of the squared simulation errors over all of the hydraulic head measurements. For the particular geometry of $\mathrm{K}$ zones chosen, the results of a MODFLOWP run is a set of $K$ values that provide the "best" fit of the simulation model to the hydraulic head measurements being used for calibration.

8. Use MODFLOWP to calculate statistics to understand the precision of each of 
the estimated parameters. In particular, for each parameter estimated, the parameter standard deviation and coefficient of variation are calculated. The coefficient of variation is the standard deviation divided by the parameter estimate value. The standard deviation is used to calculate error bounds on the parameter estimate, and the coefficient of variation is a measure of the uncertainty in the estimate.

9. Use information obtained from MODFLOWP to modify the K zone geometries or modify boundary conditions and sources and sinks and better understand the aquifer behavior. The goal is to develop an accurate model with a minimum number of parameters ( $\mathrm{K}$ zones in this case).

\subsubsection{Calibration Approach Used for this Study}

The calibration performed for this study focused on steady-state flow. The transient calibration was performed subsequent to finalization of $\mathrm{K}$ zones and $\mathrm{K}$ values and used the upper layer specific yield as the sole calibration parameter (assumed spatially constant). The transient runs were also made to show the temporal changes induced in the INEL area by changing boundary conditions (underflow) and infiltration from the Big Lost River.

The model calibration was limited to the upper 200-ft layer of the model because the majority of the contaminant plumes are assumed to be located in the upper $250 \mathrm{ft}$ of the aquifer (Arnett et al. 1993). The lower layers of the aquifer provide a realistic thickness for the water movement, but the numerical model calibration was based on the assumption that the contaminants for the INEL are not transported in the lower layers of the aquifer model.
Key hydraulic head observation wells were chosen based on their proximity to the WAGs, their well screen completion, and the number of hydraulic head samples available. While non-key wells are included to ensure that the hydraulic head distribution is reasonable over the entire INEL area, calibration weighting ensures the parameter values chosen provide an accurate model for the key wells.

For this analysis, spring 1980 hydraulic head distribution was used for calibration. To be consistent with the 1980 water budget used for the simulation, 1980 hydraulic heads had to be used. Spring hydraulic heads were used to avoid the irrigation season effects on the water table. The hydraulic head data were taken from the Geoscience Environmental Restoration Information System database (Arnett and Brower 1993, Arnett and McCarthy 1993), and these data were assumed to accurately represent the hydraulic head distribution throughout the INEL in the upper $200 \mathrm{ft}$.

The zones used in the Garabedian, Spinazola, EIS, and FY 93 WAG 10 regional groundwater flow models were used as a starting point. The $K$ zones in the northern portion of the INEL were modified based on the results of the WAG 1 (Test Area North) groundwater modeling (Schafer-Perini 1993). In areas outside the INEL, the hydraulic conductivity zones defined in the Garabedian and Spinazola models were used (as described in Section 3.3). In the vicinity of the INEL, zones defined for the EIS and WAG 10 models were modified during the calibration to best simulate the 1980 hydraulic head observations. Initial $\mathrm{K}$ values were chosen based on the results from Garabedian, Spinazola, EIS, and WAG 10 groundwater modeling studies. 


\subsubsection{Calibration Targets for Heads, Fluxes, and Parameters}

The following five types of calibration targets were used for this modeling study and are discussed in the following paragraphs:

(1) hydraulic head, (2) hydraulic head gradient, (3) water budget, (4) parameter value range, and (5) parameter reliability. The targets have been quantified to the extent possible; however, significant qualitative information must also be evaluated.

The defined calibration targets are technically reasonable. In order to define calibration targets that are reasonable with respect to risk, the WAG 10 contaminant transport objectives will have to be clearly defined.

\subsubsection{Hydraulic Head. The focus for} calibration is on the upper layer because of the assumption that contaminant transport occurs primarily in the upper portion of the aquifer. Some head measurements are available at wells that are open across all four layers. These observations are not included in this model calibration.

For the simulation model to be considered calibrated, the areal fit to steady state hydraulic heads must be reasonable (spring 1980 head measurements were used as surrogates for steady state). Based on recent head estimates after corrections for well deviation, hydraulic head measurements have maximum errors on the order of $\pm 0.1 \mathrm{~m}$ or $\pm 0.33 \mathrm{ft}$ (Wylie 1994, Table-1). Therefore, for the 21 key well locations within the INEL, a target mean absolute value of the difference between the simulated and measured heads (residual) of less than $\pm 0.33 \mathrm{ft}$ was chosen. Because of the heterogeneity of the system, this target is reasonable as an average residual but probably unreachable as a maximum residual for a regional scale model with large scale $\mathrm{K}$ zones defined. However, a target of $\pm 3.3 \mathrm{ft}$ (10 times the measurement error) should be an achievable maximum residual for the 21 key wells. This ensures that the model reasonably reproduces the measured head values over each of the WAGs. Refinements to the model at the WAG level will be needed to achieve a calibration appropriate for the local scale. At this time not all of the wells have had well deviation surveys performed; therefore, it is possible that some measurements used will have errors greater than \pm 0.33 - $\mathrm{ft}$ error. Some minor recalibration may be needed after the data from all the wells are corrected for well deviation.

Based on an acceptable regional gradient target of $1 \%$ error, the maximum head residual target of $\pm 3.3 \mathrm{ft}$ is reasonable (Section 5.1.3.2).

In the area outside the INEL, the steady state hydraulic head distribution should be similar to that obtained by Garabedian (1992) and Spinazola (1994). The Garabedian and Spinazola models (parameter zones and values) were used to the extent possible to satisfy this target and maximize the consistency between the current model and the USGS models. The current model is a significant variation on both the Garabedian and Spinazola models; therefore, some differences are expected and considered acceptable because the current model focuses on the INEL.

At the 21 key wells, the absolute value of the mean difference between the simulated and measured transient (monthly 1980 to 1990) heads should be less than $3.3 \mathrm{ft}$.

\subsubsection{Hydraulic Head Gradient. For} each of the WAG areas, the simulated steady state hydraulic gradient should be within $10 \%$ of the measured gradient based on heads at key wells in the area. This gradient value combined with the areal head requirement constrains the optimization.

Over the entire INEL, the steady state error in the head gradient should be less than $1 \%$. For 
a total head drop of about $260 \mathrm{ft}$ over the INEL, this translates to a maximum residual of less than $3.3 \mathrm{ft}$.

5.1.3.3 Water Budget. The steady state aquifer discharge between Milner and King Hill (simulated in the Garabedian model) should be reproduced within $5 \%$. The steady state mass balance calculated by MODFLOWP should be less than $0.1 \%$ to ensure numerical convergence of the simulation model.

\subsubsection{Parameter Value Range.}

Table 5-2 presents the rock types for various $K$ zones defined by Garabedian 1992 (Table 19), the $\mathrm{K}$ value estimated for each rock type in each $\mathrm{K}$ zone, and the range of conductivities shown in Freeze and Cherry (1979). Based on this information as well as the information given in Plate 5 of Garabedian (1992) regarding the rock characteristics of the different regions of the ESRP aquifer, the $\mathrm{K}$ target ranges are defined based on the $K$ zones defined by Garabedian. The $\mathrm{K}$ ranges are shown as the last two rows in Table 5-2.

The target range for specific yield is 0.01 to 0.3 , and the target range for storage coefficient is $5 \times 10^{-3}$ to $5 \times 10^{-5}$ (Freeze and Cherry 1979). These values bound the values used in the past in Garabedian (1992) and Arnett and Springer (1993). The layer 1 values for storage coefficient (actually specific yield) that Garabedian used for his transient simulations are shown in Table 5-3 (Garabedian 1992, Figure 2). The following values were calculated as a weighted average of the storage coefficient values assumed for each rock type: basalt 0.05 , sand and gravel 0.20 , sand 0.20 , silt and clay 0.20 , and silicic volcanics 0.05 . Layers below layer 1 were assumed to be confined and assigned a constant value of $10^{-4}$ to be consistent with the Garabedian model. Arnett and Springer (1993) used a constant specific yield value of 0.15 for their EIS transient simulations.
5.1.3.5 Parameter Reliability. The reliability of the parameter estimates are quantified in the MODFLOWP output (Hill 1992). The coefficient of variation is used to represent the reliability. For each parameter the coefficient of variation should be less than 1 . Setting a coefficient of variation goal minimizes the number of parameter zones and, thus, improves parameter reliability.

\subsection{Calibration Results}

Figure 5-2 shows the locations of all 48 observation wells used for calibration. This section compares two parameter estimation runs: (1.) varying the weight so the $21 \mathrm{key}$ wells are strongly weighted and the other wells are negligible weighted and (2) setting the weight in all 48 observation wells the same. The following sections compare simulation results to calibration targets.

\subsubsection{Hydraulic Head}

The first head-related calibration target criterion was to match the hydraulic heads at the 21 key wells with a maximum error of \pm 3.3 $\mathrm{ft}$ and an average error of less than $\pm 0.33 \mathrm{ft}$. The results of the calibration assigning uniform weights to the 21 key wells and very small weights to the other 27 observation wells are shown in Tables 5-4 and 5-5 and Figure 5-3. Table 5-4 lists the measured spring 1980 hydraulic head, simulated hydraulic head, and residual for the observation wells. Figure 5-3 plots the residuals, and Table 5-5 lists the calibrated $K$ values and the estimated coefficient of variation.

As shown in Table 5-4, the residuals for 13 out of 21 key wells meet the hydraulic head calibration target of a residual less than $3.3 \mathrm{ft}$. Of the seven wells with residuals greater than $3.3 \mathrm{ft}$, two have residuals less than $5 \mathrm{ft}$ and the other five have residuals ranging from 5.30 to $8.96 \mathrm{ft}$. The maximum and minimum residual for the key wells are 8.96 and $-5.44 \mathrm{ft}$. The 
Table 5-2. Target range for the $\mathrm{K}$ values $(\mathrm{ft} / \mathrm{sec})$.

\begin{tabular}{|c|c|c|c|c|c|c|c|c|}
\hline \multirow[b]{2}{*}{ Zone } & \multirow[b]{2}{*}{ Rock } & \multicolumn{5}{|c|}{ Rock type } & \multirow[b]{2}{*}{$\begin{array}{l}\text { Estimated } \\
\text { minimum } \\
\mathrm{K} \text { value }\end{array}$} & \multirow[b]{2}{*}{$\begin{array}{c}\text { Estimated } \\
\text { maximum } \\
\mathrm{K} \text { value }\end{array}$} \\
\hline & & $\begin{array}{l}\text { (B) Basalt } \\
\text { (brown) } \\
\left(\times 10^{-4}\right)\end{array}$ & $\begin{array}{c}\text { (O) Sand and } \\
\text { gravel (orange) } \\
\left(\times 10^{-4}\right)\end{array}$ & $\begin{array}{l}\text { (Y1) Sand } \\
\text { (yellow) } \\
\left(\times 10^{-4}\right)\end{array}$ & $\begin{array}{l}\text { (Y2) Clay and } \\
\text { silt (yellow) } \\
\left(\times 10^{-6}\right)\end{array}$ & $\begin{array}{c}\text { (R) Silicic } \\
\text { volcanics } \\
\text { (rhyolite) (red) } \\
\left(\times 10^{-6}\right)\end{array}$ & & \\
\hline 1 & 0 & 0.052 & 11 & 0.11 & 2.3 & 7.5 & $10^{-5}$ & $10^{\circ}$ \\
\hline 2 & $\mathrm{Y} 1$ & 5.5 & 90 & .90 & .75 & 7.5 & $10^{-12}$ & $10^{-2}$ \\
\hline 3 & $\mathrm{Y} 1$ & 550 & 73 & .73 & 2.3 & 7.5 & $10^{-12}$ & $10^{-2}$ \\
\hline 4 & $0, Y_{1}$ & .9 & 17 & .17 & .75 & 7.5 & $10^{-5}$ & $10^{0}$ \\
\hline 5 & Y1 & 803 & 110 & 1.1 & 2.3 & 7.5 & $10^{-12}$ & $10^{-2}$ \\
\hline 6 & $\mathrm{O}, \mathrm{B}$ & 2.4 & 47 & .63 & 2.3 & 7.5 & $10^{-7}$ & $10^{\circ}$ \\
\hline 7 & $\mathrm{~B}$ & 2.1 & 41 & .41 & 2.3 & 7.5 & $10^{-12}$ & $10^{-1}$ \\
\hline 8 & $\mathrm{Y} 1, \mathrm{~B}$ & 56 & 140 & 1.4 & .38 & 7.5 & $10^{-12}$ & $10^{-1}$ \\
\hline 9 & $Y 1, B$ & $.75^{\circ}$ & 7.5 & .075 & .75 & 7.5 & $10^{-12}$ & $10^{-1}$ \\
\hline 10 & $\mathrm{Y} 1, \mathrm{~B}$ & 5.7 & 110 & 1.1 & .75 & 7.5 & $10^{-12}$ & $10^{-1}$ \\
\hline 11 & $\mathrm{O}, \mathrm{B}, \mathrm{Y}$ & 3.8 & 3.8 & 3.8 & .38 & 7.5 & $10^{-12}$ & $10^{\circ}$ \\
\hline 12 & B & 23 & 75 & .75 & 2.3 & 7.5 & $10^{-7}$ & $10^{\circ}$ \\
\hline 13 & $Y 1, O$ & 580 & 2,000 & .10 & .38 & 7.5 & $10^{-12}$ & $10^{0}$ \\
\hline 14 & all & 1,100 & 1,900 & 1.9 & 2.3 & 7.5 & $10^{-12}$ & $10^{0}$ \\
\hline 15 & $Y$ & 11 & 71 & .71 & .38 & 7.5 & $10^{-12}$ & $10^{-2}$ \\
\hline 16 & $\mathrm{~B}, \mathrm{O}, \mathrm{Y}$ & 230 & 38 & $.38^{\circ}$ & 2.3 & 7.5 & $10^{-12}$ & $10^{\circ}$ \\
\hline 17 & All & 61 & 330 & .66 & 2.3 & 7.5 & $10^{-12}$ & $10^{0}$ \\
\hline 18 & $O, R$ & 6 & 11 & 1.1 & 2.3 & 7.5 & $10^{-8}$ & $10^{\circ}$ \\
\hline 19 & $Y 1, B$ & 670 & 1,700 & 1.7 & 2.3 & 7.5 & $10^{-12}$ & $10^{-1}$ \\
\hline 20 & B & 150 & 71 & .71 & 2.3 & 7.5 & $10^{-7}$ & $10^{-1}$ \\
\hline 21 & $\mathrm{~B}$ & 590 & 83 & .83 & 2.3 & 7.5 & $10^{-7}$ & $10^{-1}$ \\
\hline 22 & $B, Y$ & 50 & 29 & .29 & .38 & 7.5 & $10^{-12}$ & $10^{-1}$ \\
\hline 23 & B & 120 & 83 & .83 & 2.3 & 7.5 & $10^{-7}$ & $10^{-1}$ \\
\hline 24 & $B, Y$ & 440 & 83 & .83 & 2.3 & 7.5 & $10^{-12}$ & $10^{-1}$ \\
\hline 25 & $Y, O, B$ & 2.9 & 59 & .59 & 2.3 & 7.5 & $10^{-12}$ & $10^{\circ}$ \\
\hline 26 & $Y 1$ & 200 & 48 & .48 & 2.3 & 7.5 & $10^{-12}$ & $10^{-2}$ \\
\hline 27 & $\mathrm{Y}, \mathrm{B}$ & 68 & 47 & .62 & 2.3 & 7.5 & $10^{-12}$ & $10^{-1}$ \\
\hline 28 & $\mathrm{Y}, \mathrm{B}$ & 3 & 58 & .58 & 2.3 & 7.5 & $10^{-7}$ & $10^{-1}$ \\
\hline 29 & $Y$ & 1.5 & 31 & .31 & .75 & 7.5 & $10^{-12}$ & $10^{-2}$ \\
\hline
\end{tabular}


Table 5-2. (continued)

Rock type

\begin{tabular}{|c|c|c|c|c|c|c|c|c|}
\hline Zone & Rock & $\begin{array}{l}\text { (B) Basalt } \\
\text { (brown) } \\
\left(\times 10^{-4}\right)\end{array}$ & $\begin{array}{l}\text { (O) Sand and } \\
\text { gravel (orange) } \\
\left(\times 10^{-4}\right)\end{array}$ & $\begin{array}{l}\text { (Y1) Sand } \\
\text { (yellow) } \\
\left(\times 10^{-4}\right)\end{array}$ & $\begin{array}{c}(\times 2) \text { Clay and } \\
\text { siit (yellow) } \\
\left(\times 10^{-6}\right)\end{array}$ & $\begin{array}{c}\text { (R) Silicic } \\
\text { volcanics } \\
\text { (rhyolite) (red) } \\
\left(\times 10^{-6}\right)\end{array}$ & $\begin{array}{l}\text { Estimated } \\
\text { minimum } \\
\mathrm{K} \text { value }\end{array}$ & $\begin{array}{c}\text { Estimated } \\
\text { maximum } \\
\text { K value }\end{array}$ \\
\hline 30 & $B, Y$ & 3.9 & 11 & .11 & .38 & 7.5 & $10^{-12}$ & $10^{-1}$ \\
\hline 31 & $B, Y$ & 1.6 & 26 & .26 & .75 & 7.5 & $10^{-12}$ & $10^{-1}$ \\
\hline 32 & $Y$ & 380 & 38 & .38 & 2.3 & 7.5 & $10^{-12}$ & $10^{-1}$ \\
\hline 33 & B & 420 & 210 & 2.1 & 2.3 & 7.5 & $10^{-7}$ & $10^{-1}$ \\
\hline 34 & $\mathrm{~B}, \mathrm{O}, \mathrm{Y}$ & 250 & 300 & .30 & 2.3 & 7.5 & $10^{-12}$ & $10^{0}$ \\
\hline 35 & $Y$ & 66 & 140 & 66 & .38 & 7.5 & $10^{-12}$ & $10^{-2}$ \\
\hline 36 & 0 & 600 & 1,500 & 600 & 7.5 & 7.5 & $10^{-5}$ & $10^{\circ}$ \\
\hline 37 & 0 & 15 & 15 & .23 & 2.3 & 7.5 & $10^{-5}$ & $10^{\circ}$ \\
\hline 38 & $B, Y$ & 150 & 83 & .83 & 3.8 & 7.5 & $10^{-12}$ & $10^{-1}$ \\
\hline 39 & B & 120 & 18 & .18 & 2.3 & 7.5 & $10^{-7}$ & $10^{-1}$ \\
\hline 40 & $\mathrm{~B}, \mathrm{Y}$ & 200 & 260 & .26 & 2.3 & 7.5 & $10^{-12}$ & $10^{-1}$ \\
\hline \multicolumn{9}{|c|}{ Rock K Range (ft/s) } \\
\hline $\operatorname{Min}^{\mathrm{a}}$ & & $5.2 \mathrm{E}-6$ & $3.8 \mathrm{E}-4$ & $7.5 \mathrm{E}-6$ & $3.8 \mathrm{E}-7$ & $7.5 \mathrm{E}-6$ & & \\
\hline $\operatorname{Max}^{a}$ & & $1.1 \mathrm{E}-1$ & $2.0 \mathrm{E}-1$ & $6.0 \mathrm{E}-2$ & $7.5 E-6$ & $7.5 \mathrm{E}-6$ & & \\
\hline $\operatorname{Min}^{b}$ & & $3.3 \mathrm{E}-7$ & $1.6 \mathrm{E}-5$ & $1.6 \mathrm{E}-5$ & 3.3E-12 & $3.3 E-8$ & & \\
\hline $\operatorname{Max}^{b}$ & & $1.6 \mathrm{E}-1$ & $3.3 \mathrm{E}+0$ & 3.3E-2 & $3.3 \mathrm{E}-5$ & $3.3 \mathrm{E}-4$ & & \\
\hline
\end{tabular}


Table 5-3. Layer 1 average storage coefficient (or specific yield) values (Garabedian 1992, Figure 24).

\begin{tabular}{llllllll}
\hline $\begin{array}{c}\text { Zone } \\
\text { number }\end{array}$ & $\begin{array}{c}\text { Storage } \\
\text { coefficient }\end{array}$ & $\begin{array}{c}\text { Zone } \\
\text { number }\end{array}$ & $\begin{array}{c}\text { Storage } \\
\text { coefficient }\end{array}$ & $\begin{array}{c}\text { Zone } \\
\text { number }\end{array}$ & $\begin{array}{c}\text { Storage } \\
\text { coefficient }\end{array}$ & $\begin{array}{c}\text { Zone } \\
\text { number }\end{array}$ & $\begin{array}{c}\text { Storage } \\
\text { coefficient }\end{array}$ \\
\hline 1 & 0.10 & 11 & 0.083 & 21 & 0.050 & 31 & 0.091 \\
2 & 0.076 & 12 & 0.050 & 22 & 0.095 & 32 & 0.078 \\
3 & 0.067 & 13 & 0.18 & 23 & 0.052 & 33 & 0.050 \\
4 & 0.13 & 14 & 0.064 & 24 & 0.097 & 34 & 0.062 \\
5 & 0.11 & 15 & 0.11 & 25 & 0.082 & 35 & 0.14 \\
6 & 0.094 & 16 & 0.071 & 26 & 0.073 & 36 & 0.20 \\
7 & 0.050 & 17 & 0.15 & 27 & 0.061 & 37 & 0.098 \\
8 & 0.11 & 18 & 0.077 & 28 & 0.055 & 38 & 0.069 \\
9 & 0.076 & 19 & 0.073 & 29 & 0.08 & 39 & 0.050 \\
10 & 0.073 & 20 & 0.050 & 30 & 0.079 & 40 & 0.064 \\
\hline
\end{tabular}




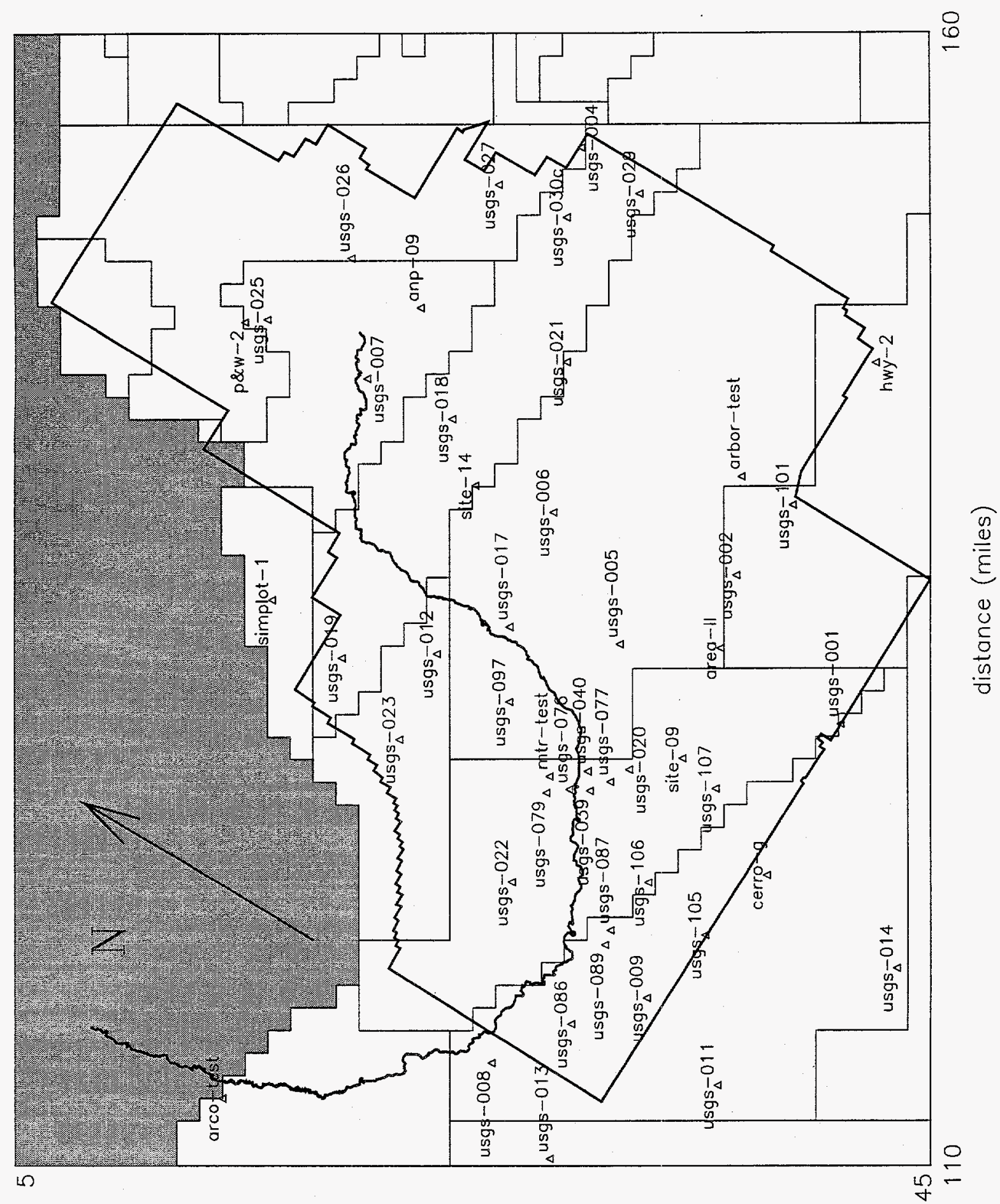

فํ. 
Table 5-4. Comparison of measured and simulated hydraulic heads for the calibration run with the 21 key wells weighted heavier than the other 27 wells. $^{\text {a }}$

\begin{tabular}{|c|c|c|c|c|}
\hline Well name & $\begin{array}{c}\text { Measured } \\
\text { hydraulic head } \\
(\mathrm{ft})\end{array}$ & $\begin{array}{c}\text { Simulated } \\
\text { hydraulic head } \\
(\mathrm{ft})\end{array}$ & $\begin{array}{l}\text { Residual } \\
\quad(\mathrm{ft})\end{array}$ & $\begin{array}{l}\text { WAG associated } \\
\text { with key well }\end{array}$ \\
\hline anp-09 & 4565.3 & 4566.154 & -.854 & 1 \\
\hline arbor-test & 4486.7 & 4480.801 & 5.90 & 9 \\
\hline arco-test & 4799.4 & 4798.536 & .864 & \\
\hline area-II & 4461.0 & 4471.932 & -10.9 & \\
\hline cerro-g & 4426.2 & 4431.846 & -5.65 & \\
\hline hwy-2 & 4494.4 & 4494.310 & .0898 & \\
\hline mtr-test & 4459.3 & 4462.153 & -2.85 & $2-8$ \\
\hline$p \& w-2$ & 4580.8 & 4586.238 & -5.44 & 1 \\
\hline simplot-1 & 4684.6 & 4684.628 & $-.283 \mathrm{E}-01$ & \\
\hline site-09 & 4454.4 & 4452.035 & 2.37 & $2-8$ \\
\hline site-14 & 4526.0 & 4499.725 & 26.3 & \\
\hline usgs-001 & 4435.5 & 4447.970 & -12.5 & \\
\hline usgs-002 & 4468.7 & 4474.897 & -6.20 & 9 \\
\hline usgs-004 & 4533.6 & 4566.636 & -33.0 & \\
\hline usgs-005 & 4471.2 & 4474.234 & -3.03 & \\
\hline usgs-006 & 4486.3 & 4488.534 & -2.23 & \\
\hline usgs-007 & 4578.4 & 4569.440 & 8.96 & 1 \\
\hline usgs-008 & 4430.1 & 4421.252 & 8.85 & \\
\hline usgs-009 & 4425.2 & 4424.745 & .456 & $2-8$ \\
\hline usgs-011 & 4415.1 & 4418.798 & -3.70 & \\
\hline usgs-012 & 4491.9 & 4487.230 & 4.67 & $2-8$ \\
\hline usgs-013 & 4388.4 & 4397.899 & -9.50 & \\
\hline usgs-014 & 4417.8 & 4426.694 & -8.89 & \\
\hline usgs-017 & 4479.8 & 4482.467 & -2.67 & $2-8$ \\
\hline usgs-018 & 4535.4 & 4536.697 & -1.30 & \\
\hline usgs-019 & 4526.9 & 4545.022 & -18.1 & \\
\hline usgs-020 & 4456.0 & 4456.273 & -.273 & $2-8$ \\
\hline usgs-021 & 4508.4 & 4505.020 & 3.38 & \\
\hline usgs-022 & 4439.500 & 4442.316 & -2.82 & \\
\hline
\end{tabular}


Table 5-4. (continued).

\begin{tabular}{|c|c|c|c|c|}
\hline Well name & $\begin{array}{c}\text { Measured } \\
\text { hydraulic head } \\
\text { (ft) }\end{array}$ & $\begin{array}{c}\text { Simulated } \\
\text { hydraulic head } \\
(\mathrm{ft})\end{array}$ & $\begin{array}{l}\text { Residual } \\
\text { (ft) }\end{array}$ & $\begin{array}{l}\text { WAG associated } \\
\text { with key well }\end{array}$ \\
\hline usgs -023 & 4485.7 & 4484.897 & .803 & \\
\hline usgs-025 & 4581.8 & 4583.214 & -1.41 & \\
\hline usgs-026 & 4581.6 & 4575.447 & 6.15 & 1 \\
\hline usgs-027 & 4561.4 & 4566.329 & -4.93 & \\
\hline usgs-029 & 4527.7 & 4541.594 & -13.9 & \\
\hline usgs $-30 c$ & 4528.6 & 4550.537 & -21.9 & \\
\hline usgs $-039^{b}$ & 4458.0 & 4455.507 & 2.49 & $2-8$ \\
\hline usgs-040 & 4458.6 & 4460.491 & -1.89 & $2-8$ \\
\hline usgs-076 & 4458.7 & 4457.745 & .955 & $2-8$ \\
\hline usgs -077 & 4457.3 & 4455.592 & 1.71 & $2-8$ \\
\hline usgs-079 & 4459.0 & 4458.477 & .523 & $2-8$ \\
\hline usgs-086 & 4428.7 & 4422.620 & 6.08 & \\
\hline usgs -087 & 4429.8 & 4427.250 & 2.55 & $2-8$ \\
\hline usgs-089 & 4429.5 & 4426.850 & 2.65 & $2-8$ \\
\hline usgs -097 & 4479.4 & 4474.796 & 4.60 & $2-8$ \\
\hline usgs-101 & 4483.3 & 4477.999 & 5.30 & 9 \\
\hline usgs $-105^{b}$ & 4426.8 & 4427.654 & -.854 & \\
\hline usgs- $106^{b}$ & 4449.5 & 4430.587 & 18.9 & \\
\hline usgs- $107^{b}$ & 4440.3 & 4441.525 & -1.23 & \\
\hline
\end{tabular}

a. Key wells are identified in boldface type.

b. Measured head was not available for spring 1980; therefore, the values are interpolated from the well hydrographs. Well usgs-039 is the only key well with an estimated head value. 
Table 5-5. Final $\mathrm{K}$ values and coefficients of variation for each of the $12 \mathrm{~K}$ zones (zone locations are shown in Figure 3-16).

\begin{tabular}{lrrrrrr}
\hline & $\begin{array}{c}\text { Final K value } \\
\text { (key wells } \\
\text { only) } \\
\text { Zone } \\
\text { number }\end{array}$ & $\begin{array}{c}\text { Coefficient } \\
\text { of } \\
\left(\times 10^{-3} \mathrm{ft} / \mathrm{sec}\right)\end{array}$ & $\begin{array}{c}\text { Fanal K value } \\
\text { (all wells) } \\
\left(\times 10^{-3} \mathrm{ft} / \mathrm{sec}\right)\end{array}$ & $\begin{array}{c}\text { Coefficient } \\
\text { of } \\
\text { variation }\end{array}$ & K1/K2 & $\begin{array}{c}\text { Percent } \\
\text { difference } \\
\text { in Ks }\end{array}$ \\
\hline 51 & 1.70 & 0.19 & 1.71 & 0.03 & 0.99 & 0.6 \\
53 & 5.31 & 0.20 & 4.57 & 0.43 & 1.16 & -13.9 \\
55 & 52.90 & 0.73 & 56.60 & 0.75 & 0.93 & 7.0 \\
56 & 3.64 & 1.08 & 7.03 & 0.88 & 0.52 & 93.1 \\
57 & 11.60 & 0.37 & 15.60 & 0.54 & 0.74 & 34.5 \\
54 & 57.00 & 1.33 & 58.40 & 0.80 & 0.98 & 2.5 \\
60 & 7.56 & 2.38 & 0.89 & 1.76 & 8.48 & -88.2 \\
58 & 96.20 & 1.11 & 112.00 & 0.89 & 0.86 & 16.4 \\
59 & 7.72 & 1.32 & 12.30 & 0.66 & 0.63 & 59.3 \\
12 & 6.20 & 0.47 & 6.76 & 0.30 & 0.92 & 9.0 \\
62 & 1.33 & 0.14 & 1.12 & 0.19 & 1.19 & -15.8 \\
61 & 0.82 & 0.65 & 0.83 & 0.15 & 1.00 & 0.5 \\
\hline
\end{tabular}


5-14 

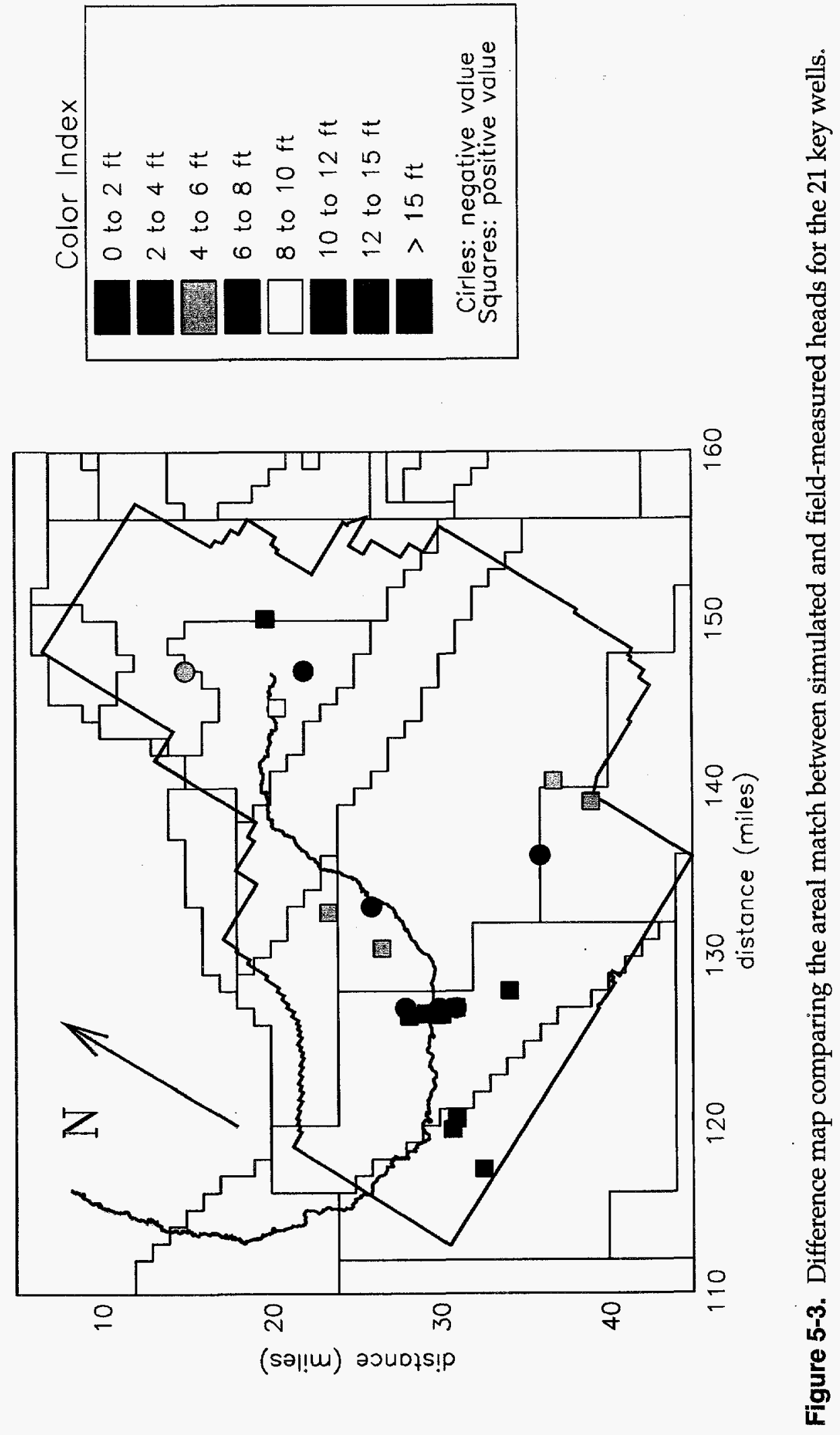
The final $\mathrm{K}$ values range from $0.82 \times 10^{-3} \mathrm{ft}$ / sec in zone 61 (on the margin of the ESRP near the Little Lost River) to $96.2 \times 10^{-3} \mathrm{ft} / \mathrm{sec}$ in zone 58 (southeast of the INEL). The coefficient of variation is greater than the calibration target 1 , for zones 56 (1.08), 54 (1.33), 60 (2.38), and 58 (1.11). The relatively large coefficients of variation imply that the set of observation wells used for calibration are not sufficiently constraining the mathematical model. It is necessary to perform the calibration with all the observation wells to see if the reliability of the estimates can be improved.

The results of the calibration assigning equal weights to all wells are shown in Tables 5-5 and 5-6 and Figure 5-4. Table 5-6 lists the measured spring 1980 hydraulic head, simulated hydraulic head, and residual for the observation wells. Figure 5-4 plots the residuals, Table 5-5 lists the calibrated $K$ values and the estimated coefficient of variation.

As shown in Table 5-6, the residuals for 11 out of 21 key wells meet the hydraulic head calibration target of a residual less than $3.3 \mathrm{ft}$. Of the ten wells with residuals greater than $3.3 \mathrm{ft}$, three have residuals less than $5 \mathrm{ft}$ and the other seven have residuals ranging from 5.48 to $11.2 \mathrm{ft}$. The maximum and minimum residual for the key wells are 11.2 and $-7.16 \mathrm{ft}$. The average residual of all 48 wells is -0.16 ; the average residual of the key wells is 0.88 .

The final $\mathrm{K}$ values range from $0.83 \times 10^{-3}$ to $112 \times 10^{-3} \mathrm{ft} / \mathrm{sec}$. The zone $60 \mathrm{~K}$ value for this run is more than eight times smaller than the zone $60 \mathrm{~K}$ value identified when only key wells were strongly weighted in the calibration. For zone 56 , the $\mathrm{K}$ value is about twice as large as the $K$ value identified when the key wells were strongly weighted. Only zone 60 has a coefficient of variation greater than 1 . This is a significant improvement over the key wells-only run.

To reduce the minimum and maximum residuals further, more $\mathrm{K}$ zones would have to be added to the model, which would reduce the reliability of the $\mathrm{K}$ estimates. Therefore, the calibration values were determined to be adequate, and the calibration procedure was stopped.

The second head-related calibration target criterion was a qualitative target to remain consistent with the hydraulic head distribution simulated in the Garabedian and Spinazola models. Figure 5-5 is a contour map that shows a fair comparison between the hydraulic head results of the current model and the Garabedian model in general.

Figure $5-6$ is a contour map showing the difference between the Spinazola and current model solutions. These are areas in the model domain where the current model simulated hydraulic head is significantly different than either the Garabedian or Spinazola model results. These differences are a result of the simplifications made to the Garabedian and Spinazola models and changes made in the area of the INEL. In particular, (a) changing the scale from the Garabedian model (4 $\times 4-\mathrm{mi}$ grids) to the current model ( $1 \times 1$-mi grids) significantly influences the model near the boundaries and along the Snake River, (b) combining the top two layers (one confined and one unconfined) of the Spinazola model and treating it as one confined layer eliminates the interaction between the two layers; therefore, the current model cannot simulate the complex hydraulic head distribution simulated by the Spinazola model, and (c) modifying the $\mathrm{K}$ values in the INEL area provides a good fit at the INEL because the Garabedian model didn't accurately simulate the head distribution in the area of the INEL. 
Table 5-6. Comparison of measured and simulated hydraulic heads for the calibration run when all 48 wells are equally weighted. ${ }^{a}$

\begin{tabular}{|c|c|c|c|c|}
\hline Well name & $\begin{array}{c}\text { Measured } \\
\text { hydraulic head } \\
\text { (ft) }\end{array}$ & $\begin{array}{c}\text { Simulated } \\
\text { hydraulic head } \\
(\mathrm{ft})\end{array}$ & $\begin{array}{l}\text { Residual } \\
\quad(\mathrm{ft})\end{array}$ & $\begin{array}{l}\text { WAG associated } \\
\text { with key well }\end{array}$ \\
\hline anp-09 & 4565.3 & 4563.743 & 1.56 & 1 \\
\hline arbor-test & 4486.7 & 4480.998 & 5.70 & 9 \\
\hline arco-test & 4799.4 & 4799.440 & -.0400 & \\
\hline area-II & 4461.0 & 4473.405 & -12.4 & \\
\hline cerro-g & 4426.2 & 4432.084 & -5.88 & \\
\hline hwy-2 & 4494.4 & 4493.558 & .842 & \\
\hline mtr-test & 4459.3 & 4464.784 & -5.48 & $2-8$ \\
\hline$p \& w-2$ & 4580.8 & 4587.542 & -6.74 & 1 \\
\hline simplot-1 & 4684.6 & 4683.854 & .746 & \\
\hline site-09 & 4454.4 & 4453.570 & .830 & $2-8$ \\
\hline site-14 & 4526.0 & 4495.006 & 31.0 & \\
\hline usgs-001 & 4435.5 & 4448.438 & -12.9 & \\
\hline usgs-002 & 4468.7 & 4475.862 & -7.16 & 9 \\
\hline usgs-004 & 4533.6 & 4555.229 & -21.6 & \\
\hline usgs-005 & 4471.2 & 4474.995 & -3.79 & \\
\hline usgs-006 & 4486.3 & 4485.449 & .851 & \\
\hline usgs- -007 & 4578.4 & 4567.235 & 11.2 & 1 \\
\hline usgs-008 & 4430.1 & 4421.557 & 8.54 & \\
\hline usgs-009 & 4425.2 & 4424.960 & .240 & $2-8$ \\
\hline usgs-011 & 4415.1 & 4419.125 & -4.02 & \\
\hline usgs-012 & 4491.9 & 4482.790 & 9.11 & $2-8$ \\
\hline usgs-013 & 4388.4 & 4399.391 & -11.0 & \\
\hline usgs-014 & 4417.8 & 4427.122 & -9.32 & \\
\hline usgs-017 & 4479.8 & 4480.532 & -.732 & $2-8$ \\
\hline usgs-018 & 4535.4 & 4534.666 & .734 & \\
\hline usgs-019 & 4526.9 & 4538.625 & -11.7 & \\
\hline usgs -020 & 4456.0 & 4459.060 & -3.06 & $2-8$ \\
\hline usgs-021 & 4508.4 & 4499.567 & 8.83 & \\
\hline usgs-022 & 4439.5 & 4444.674 & -5.17 & \\
\hline
\end{tabular}


Table 5-6. (continued)

\begin{tabular}{|c|c|c|c|c|}
\hline Well name & $\begin{array}{c}\text { Measured } \\
\text { hydraulic head } \\
(\mathrm{ft})\end{array}$ & $\begin{array}{c}\text { Simulated } \\
\text { hydraulic head } \\
\text { (ft) }\end{array}$ & $\begin{array}{l}\text { Residual } \\
\text { (ft) }\end{array}$ & $\begin{array}{l}\text { WAG associated } \\
\text { with key well }\end{array}$ \\
\hline usgs-023 & 4485.7 & 4479.352 & 6.35 & \\
\hline usgs-025 & 4581.8 & 4579.550 & 2.25 & \\
\hline usgs-026 & 4581.6 & 4573.186 & 8.41 & 1 \\
\hline usgs- 027 & 4561.4 & 4560.081 & 1.32 & \\
\hline usgs-029 & 4527.7 & 4531.230 & -3.53 & \\
\hline usgs-30c & 4528.6 & 4536.230 & -7.63 & \\
\hline usgs-039 & 4458.0 & 4458.017 & -.0171 & $2-8$ \\
\hline usgs- 040 & 4458.6 & 4463.489 & -4.89 & $2-8$ \\
\hline usgs-076 & 4458.7 & 4460.298 & -1.60 & $2-8$ \\
\hline usgs-077 & 4457.3 & 4458.271 & -.971 & $2-8$ \\
\hline usgs-079 & 4459.0 & 4460.896 & -1.90 & $2-8$ \\
\hline usgs-086 & 4428.7 & 4422.868 & 5.83 & \\
\hline usgs-087 & 4429.8 & 4427.387 & 2.41 & $2-8$ \\
\hline usgs-089 & 4429.5 & 4427.002 & 2.50 & $2-8$ \\
\hline usgs-097 & 4479.4 & 4475.062 & 4.34 & $2-8$ \\
\hline usgs-101 & 4483.3 & 4478.668 & 4.63 & 9 \\
\hline usgs-105 & 4426.8 & 4427.868 & -1.07 & \\
\hline usgs-106 & 4449.5 & 4430.828 & 18.7 & \\
\hline usgs-107 & 4440.3 & 4442.117 & -1.82 & \\
\hline
\end{tabular}

a. Key wells are identified in boldface type. 


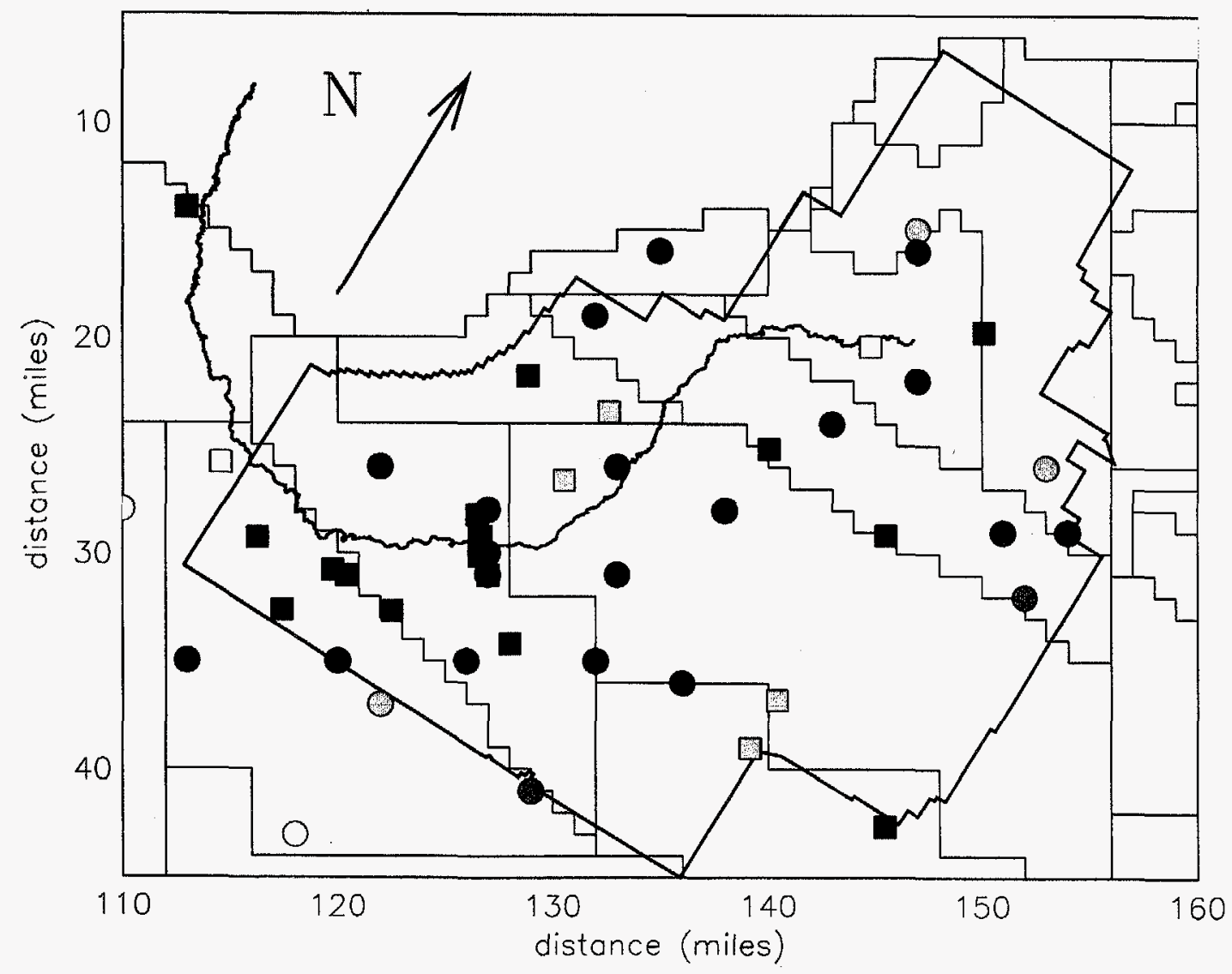

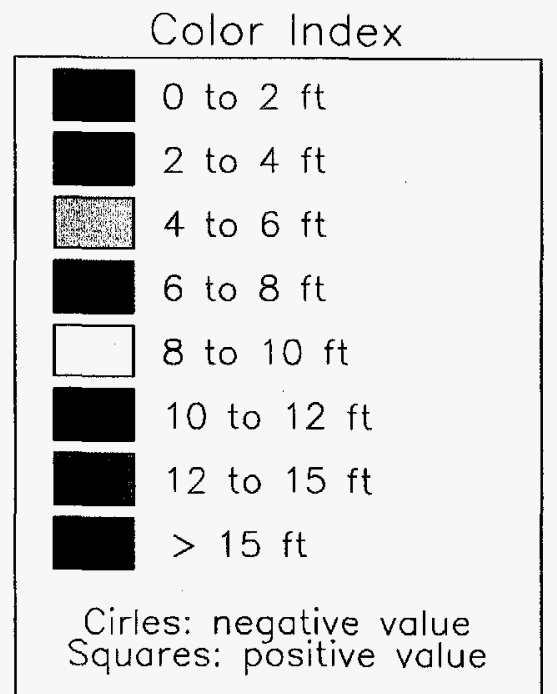

Figure 5-4. Difference map comparing the areal match between simulated and field-measured heads for the 21 key wells plus 27 additional wells used to define the regional hydraulic head distribution throughout the area of the INEL. 

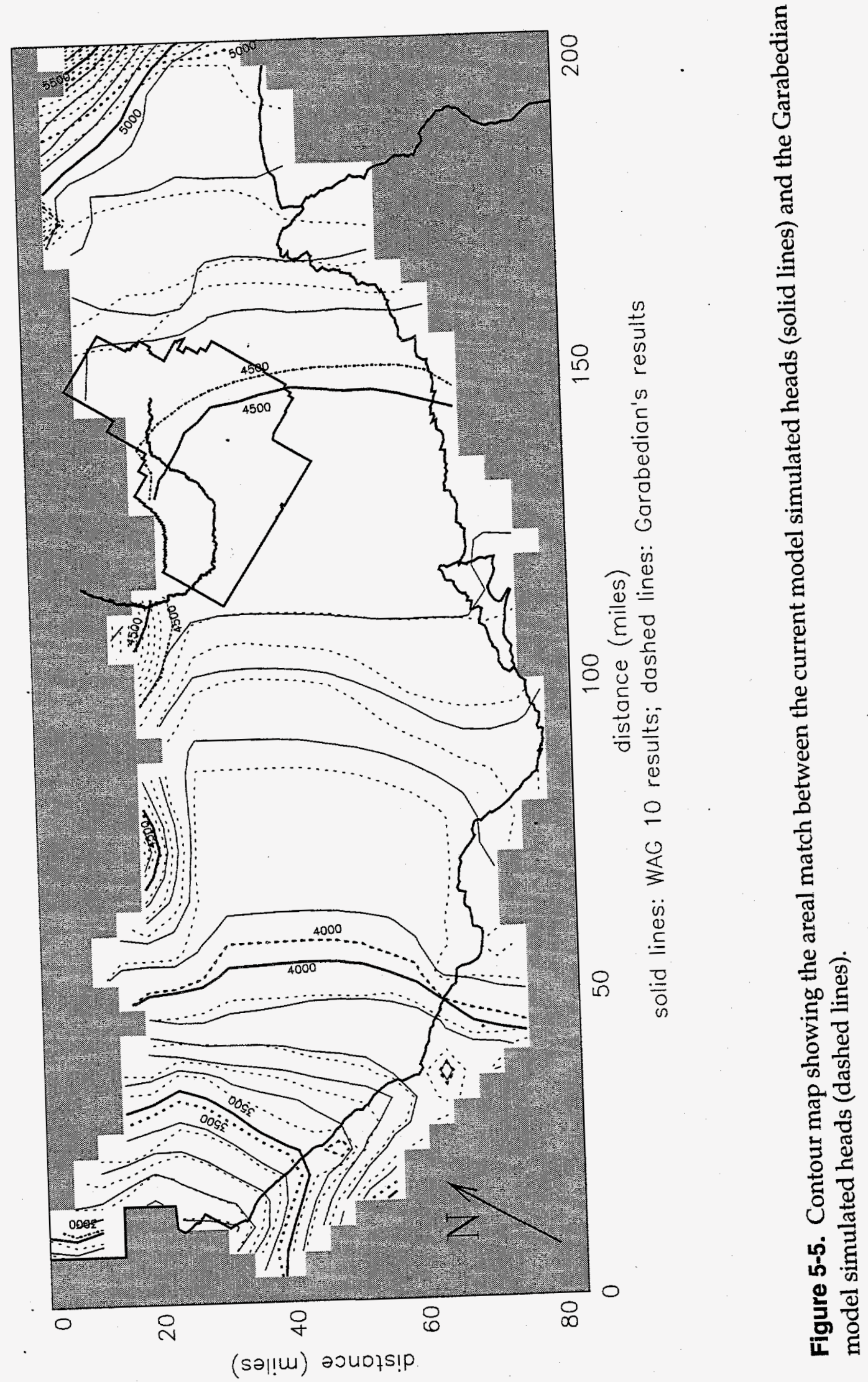


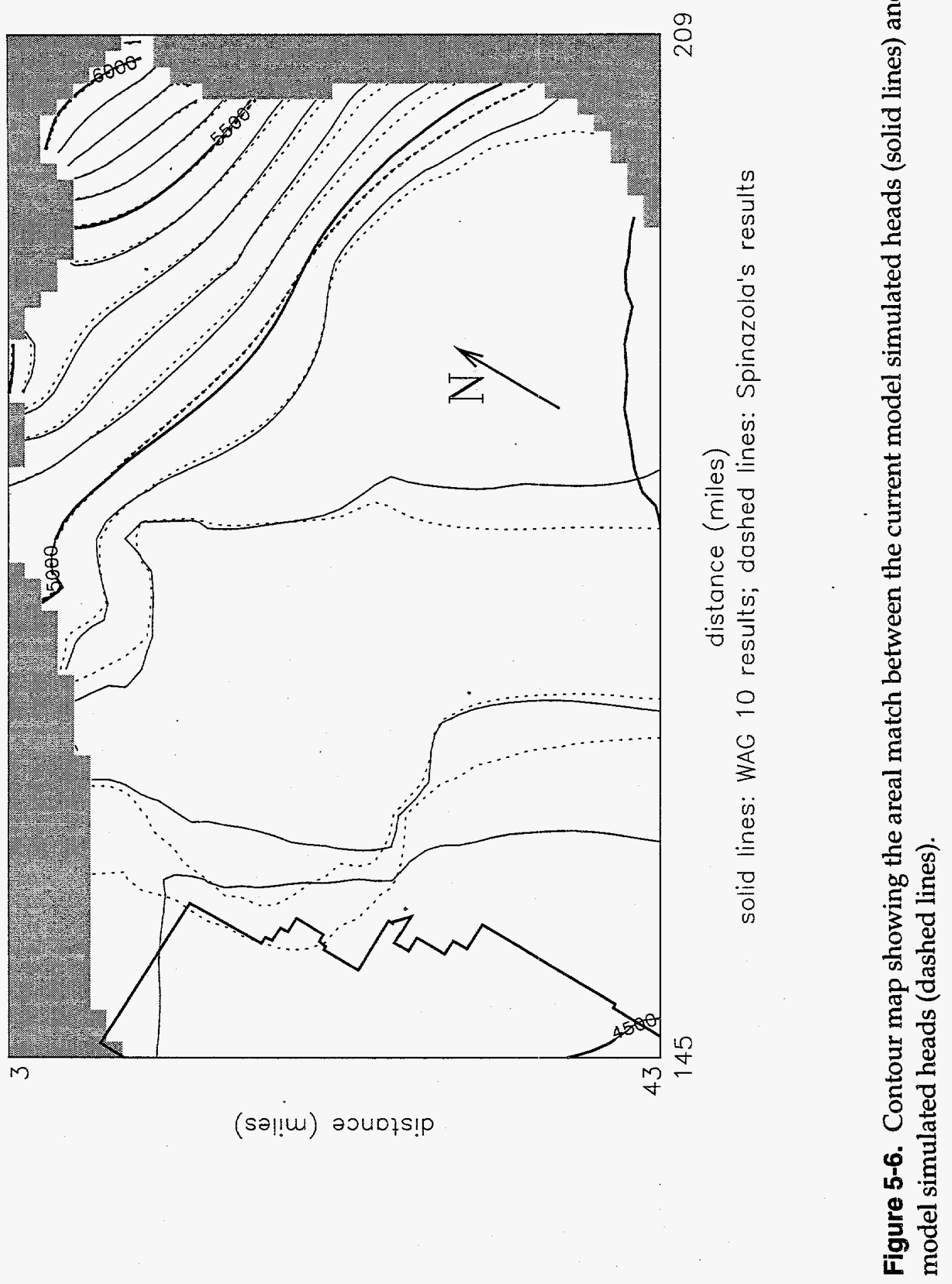


The transient runs covered the period 1980 through 1990 (11 years). The specific yield for the upper layer was the calibration parameter. Heads for all 48 wells were used for the calibration, but the non-key wells were weighted moderately less than the heads at the key wells. The calibrated value of upper layer specific yield was 0.080 , the standard deviation was 0.03 , and the coefficient of variation was 0.37 . Table B-1 in Appendix B presents the measured versus the model predicted heads for the 1980-1990 period. Figure 5-7 presents a graphical comparison of measured versus model predicted heads for a representative well at each WAG. The mean and standard deviation of the residuals for the key wells (usgs-106 has been substituted for p\&w-2) are presented in Table 5-7. Eleven of the 21 wells meet the criterion of the residual mean being less than $3.3 \mathrm{ft}$. The standard deviation of the residuals for each well is also presented as an indication of how well the model heads matched the measured heads in time. The mean of residuals was less than the residual for the steady state model for 7 wells, was larger for 12 wells, and virtually identical for 1 well.

\subsubsection{Hydraulic Head Gradient}

The second calibration target is related to the accuracy of the hydraulic gradient simulated by the calibrated model. The hydraulic

gradients at the INEL vary over both time and space; however, assuming uniform flow (1dimensional) at the time of the observations, average values over an area can be estimated based on the measured or calculated hydraulic head values. At least three observation locations are needed to estimate both the hydraulic gradient and direction. Using the hydraulic head measurements or calculated estimates at three observation well locations, the following procedure can be used to estimate the average hydraulic gradient over the area:
1. Choose three wells in the area of interest. It is best if the wells form a equilateral triangle

2. Identify the relative location in space of the three wells

3. Rank the three wells from highest to lowest head (W1, W2, and W3) with well 1 having the highest head and well 3 having the lowest (see Figure 5-8)

4. Find the point on the line between W1 and W3 (using linear interpolation) that would have the same head as W2 (imaginary well $W^{*}$ in Figure 5-8).

The direction of flow is perpendicular to the line through $\mathrm{W} 2$ and $\mathrm{W}^{*}$, and the gradient is the difference in the head value between two equal potential contours divided by the perpendicular distance between the two equipotential contours. The simulated direction and gradient of the flow can be compared using this procedure by calculating the direction and gradient of flow for the measured and simulated and comparing the results.

The hydraulic head gradient-related calibration target criterion is for the error between the hydraulic head gradient calculated from the simulated and measured hydraulic heads to be less than $10 \%$ for each of the WAG areas and $1 \%$ over the length of the INEL. During calibration it was found that a $10 \%$ error for each of the WAG areas criterion is unrealistic with a regional scale model because the wells surrounding one WAG are close enough together that the difference in head between the three wells is small relative to the error in the hydraulic head estimates. The gradient between two wells is calculated as the difference in head between the two wells divided by the horizontal distance between the wells. If the error in the head 

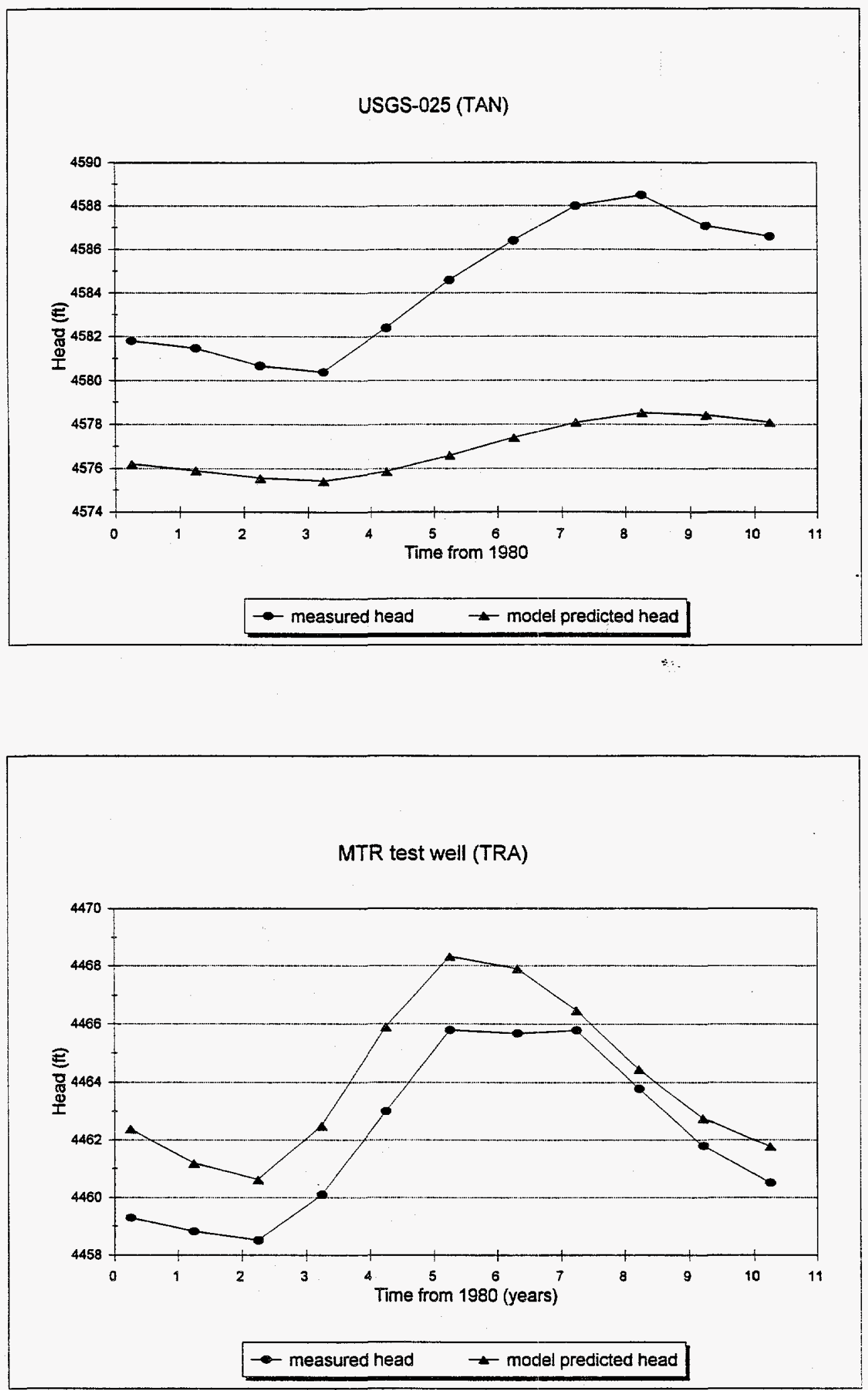

Figure 5-7. Comparison of the simulated and measured hydrographs for one well at each WAG. 

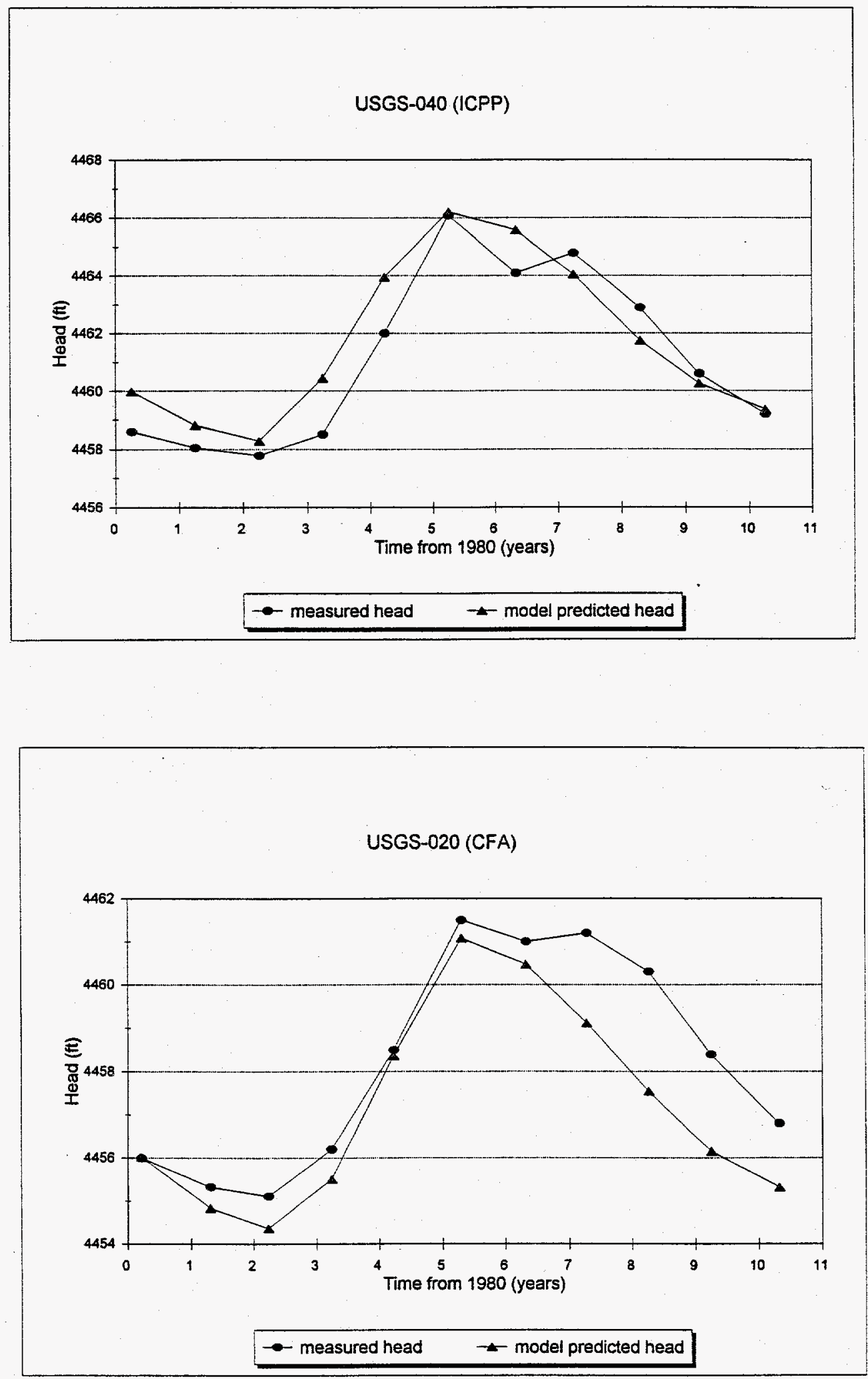

Figure 5-7. (continued). 
Site-09 Well (PBF-ARA)

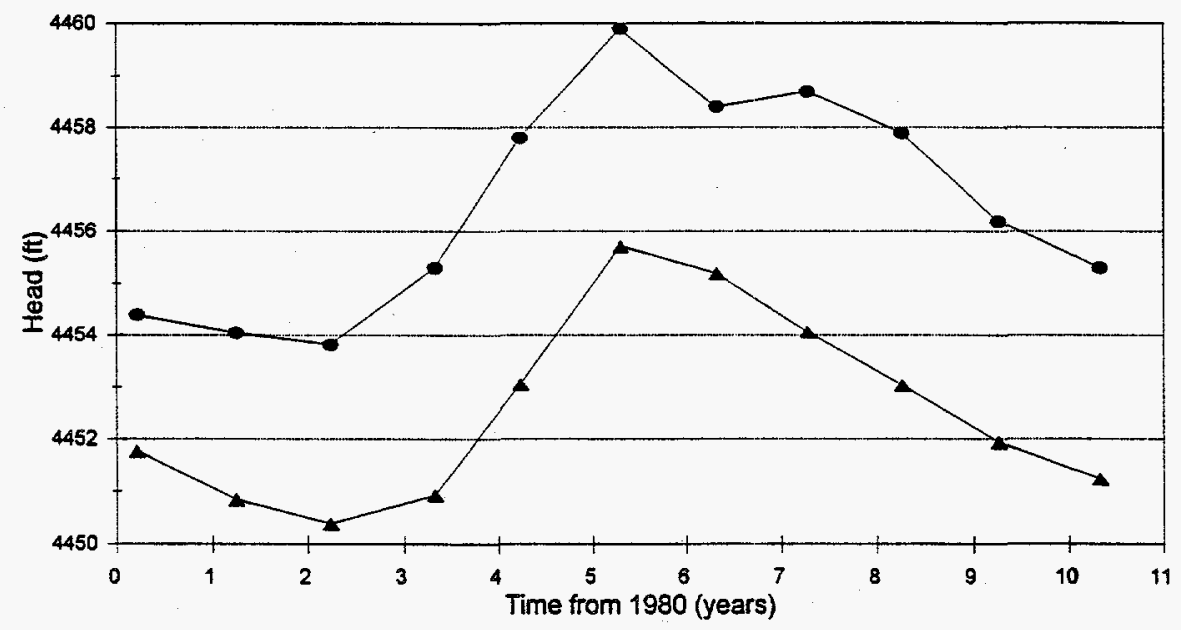

$\rightarrow$ measured head $\rightarrow$ model predicted head

\section{USGS-106 (EBR-1)}

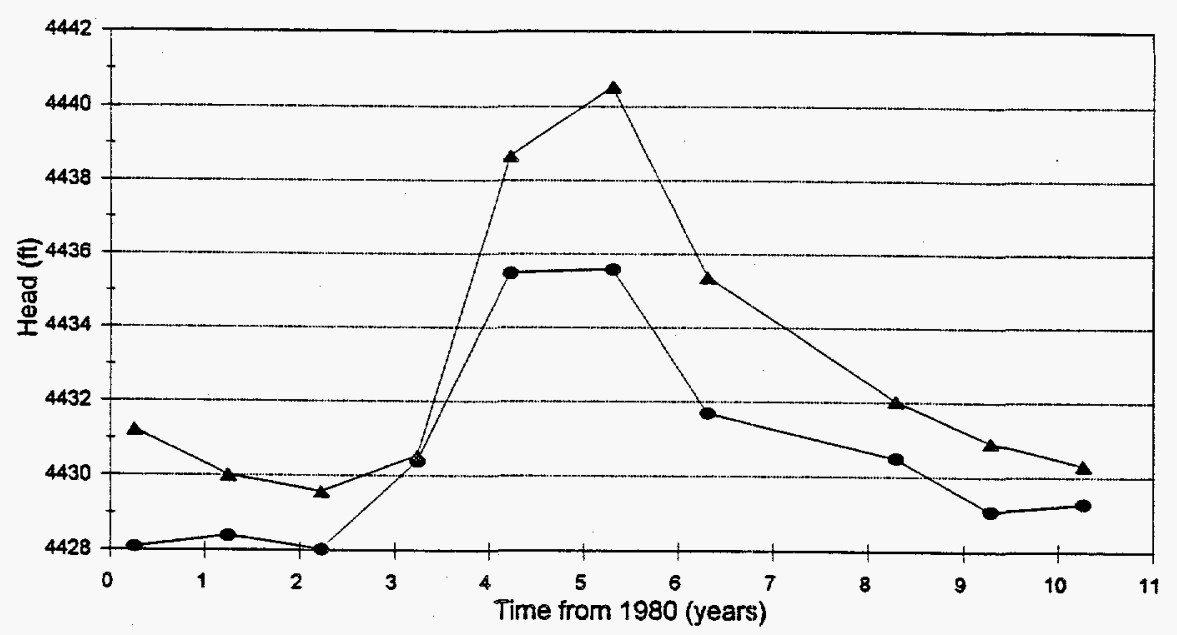

Figure 5-7. (continued). 
USGS-089 (RWMC)

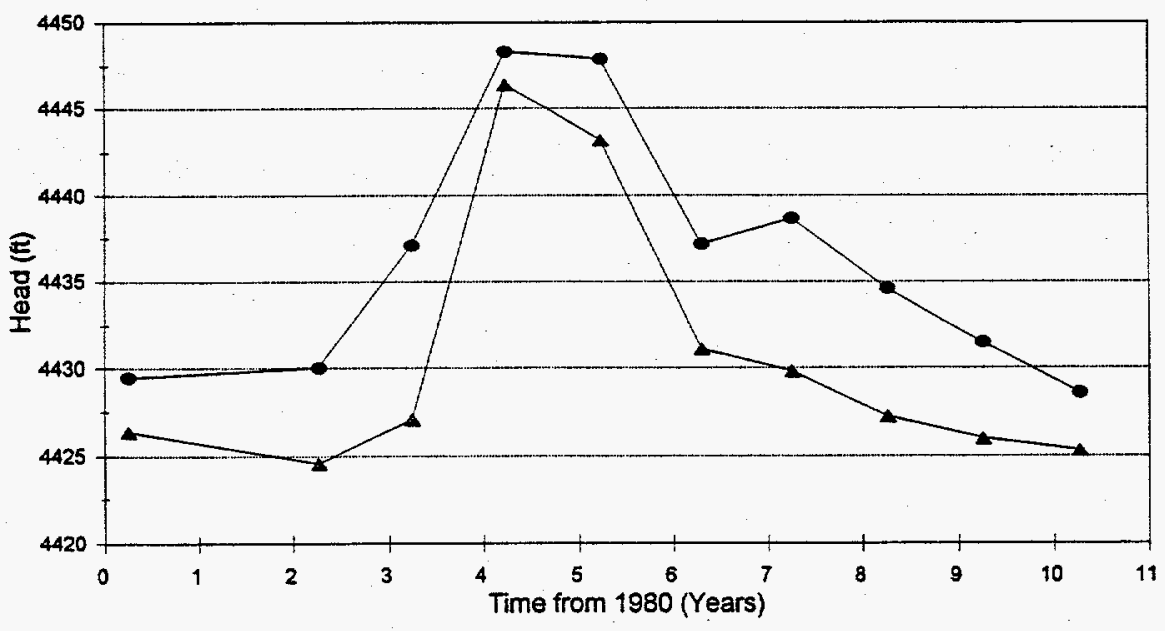

\section{USGS-097 (NRF)}

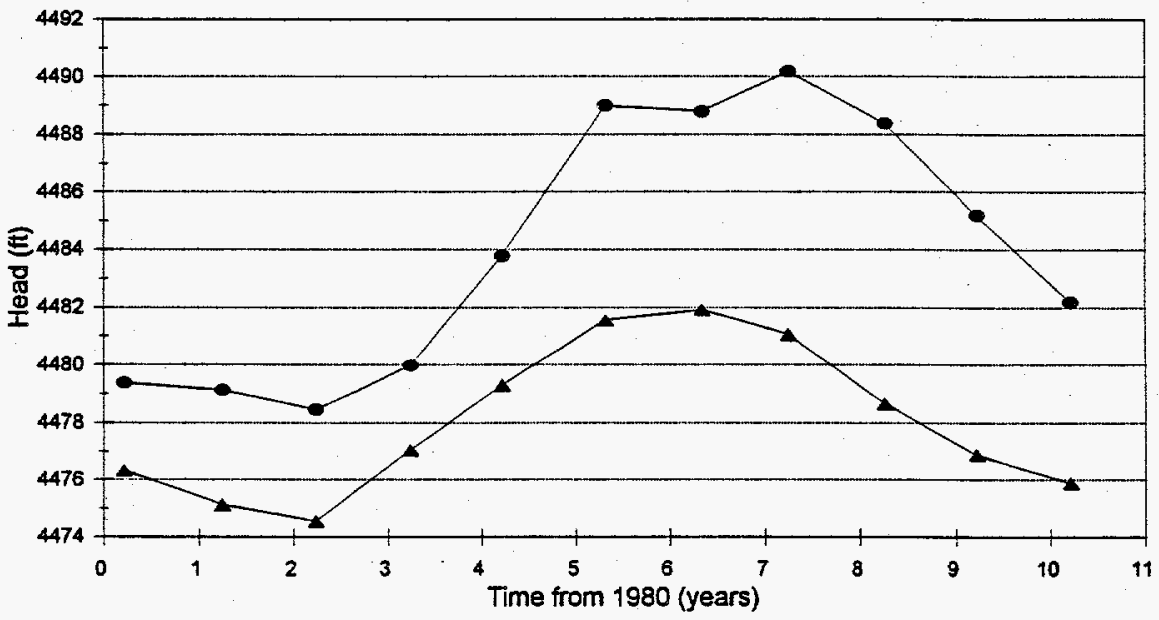

Figure 5-7. (continued). 


\section{Arbor Test Well ( ANL-W)}

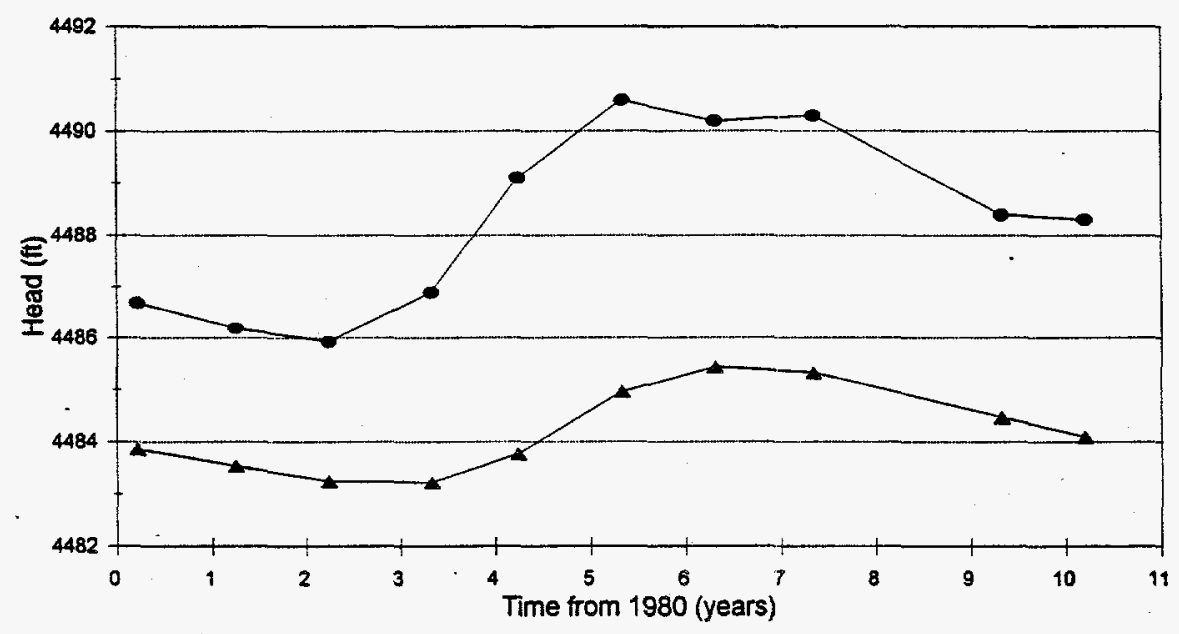

- measured head $\quad-$ model predicted head

Figure 5-7. (continued). 
Table 5-7. Mean and standard deviation of the transient model simulation residuals for the key wells.

\begin{tabular}{llccc}
\hline Well name & WAG & $\begin{array}{c}\text { Number of } \\
\text { heads }\end{array}$ & $\begin{array}{c}\text { Mean of } \\
\text { residuals }\end{array}$ & $\begin{array}{c}\text { Standard } \\
\text { deviation } \\
\text { of residuals }\end{array}$ \\
\hline anp-09 & 1 & 8 & 0.72 & 1.90 \\
usgs-106 & 4,5 & 10 & -2.27 & 1.36 \\
usgs-007 & 1 & 11 & 13.5 & 1.84 \\
usgs-026 & 1 & 10 & 11.3 & 2.18 \\
arbor test & 9 & 10 & 4.07 & 1.05 \\
usgs-002 & 9 & 11 & -3.10 & 1.12 \\
usgs-101 & 9 & 9 & 5.02 & 1.71 \\
mtr test & 2 & 11 & -1.92 & 0.84 \\
Site-09 & 5 & 11 & -3.96 & 0.70 \\
usgs-009 & 7 & 11 & 0.77 & 3.35 \\
usgs-012 & 8 & 11 & 6.48 & 2.52 \\
usgs-017 & 8 & 11 & -3.29 & 2.03 \\
usgs-020 & 4 & 11 & 1.05 & 0.89 \\
usgs-039 & 3 & 11 & 3.48 & 1.02 \\
usgs-040 & 3 & 11 & -0.56 & 1.01 \\
usgs-076 & 2 & 11 & 0.72 & 1.14 \\
usgs-077 & 3,4 & 3.39 & 1.14 \\
usgs-079 & 2 & 10 & 0.71 & 0.84 \\
usgs-087 & 7 & 2.56 & 3.23 \\
\hline usgs-089 & 7 & 5.62 & 2.44 \\
\hline
\end{tabular}




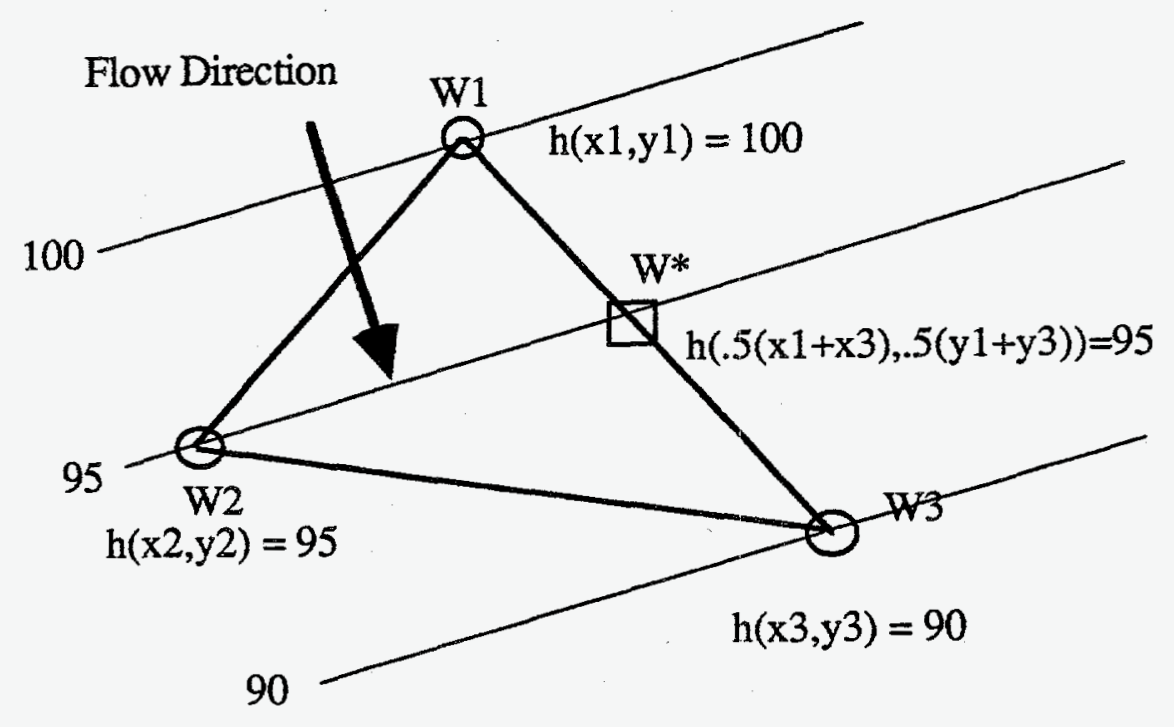

Figure 5-8. Methodology for calculating flow direction and average hydraulic gradient from the hydraulic head at three observation well locations. 
estimates is on the order of the difference, this translates into a very large error in the gradient estimate.

It is more realistic to use the average gradient and flow direction calculated from the calibrated regional model to define the scale needed for facility-specific modeling. For submodeling, a domain must be defined that can use the results of the regional scale model to provide an average hydraulic gradient across the submodel domain with an accuracy that is consistent with the accuracy needed by the modeler.

For example, if submodeling requires hydraulic head boundary conditions that define the average gradient within $10 \%$ of the measured gradient, then the total hydraulic head drop from the upgradient boundary to the downgradient boundary must be 10 times as large as the error associated with the regional model's estimated hydraulic heads. For a maximum hydraulic head error of $\pm 3.3 \mathrm{ft}$ at both the upstream and downstream boundaries of the submodel, the difference between the upstream and downstream hydraulic heads could have a maximum error of $6.6 \mathrm{ft}$. Therefore, to guarantee that the average gradient has an error of less than $10 \%$, the total head difference between the upstream and downstream boundary must be at most $66 \mathrm{ft}$.

To calibrate the hydraulic head, the gradients and directions calculated from the simulated and measured heads in the area of each WAG were compared (Table 5-8). The gradients and directions calculated from the simulated and measured heads over a larger scale in the area of WAGs 2 through 7 were then compared (Table 5-9). The numerical values of the flow directions assume that 0 is south and pi (3.14) or -pi (-3.14) radians is north. Therefore, $\mathrm{pi} / 2$ (1.57) radians is east and $-\mathrm{pi} / 2(-1.57)$ radians is west.
The maximum distance between any two of the three observation wells is included in the tables as a surrogate for the scale of the observation well set. Because of the scale of the Test Area North, Naval Reactors Facility, and Argonne National Laboratory-West WAG sites, more than one set of three observation wells were chosen to show the difference between the gradients and flow directions calculated from simulated and measured hydraulic heads. One set of three wells each are evaluated for the WAGs Test Reactor Area, Idaho Chemical Processing Plant, Central Facilities Area, Power Burst Facility, Experimental Breeder Reactor-I, and Radioactive Waste Management Complex. Many more sets could be identified, but since these WAGs are very close to each other, they are treated as a group in later results.

As shown in Table 5-8, the gradients and directions calculated in the area of the individual WAGs (local scale) were not good. The gradient and flow direction differences summarized in Table 5-8 show that

- In the entire INEL Site area, two sets of wells were used to estimate the hydraulic gradient and flow direction. The calculated gradient is $0.6 \%$ larger for the first and $3.7 \%$ larger for the second. The flow direction is off by 0.15 radians $\left(8.6^{\circ}\right)$ for the first and -0.08 radians $\left(4.6^{\circ}\right)$ for the second.

- In the Test Area North area, the calculated gradient is two times larger for the simulated hydraulic head estimates than the measured hydraulic head values, and the flow direction is off by 0.34 radians $\left(19^{\circ}\right)$.

- In the Argonne National LaboratoryWest area, three different sets of wells were used to compare the gradients and flow direction. The calculated gradient is $63 \%$ larger for the first, $36 \%$ larger for the second, and $8 \%$ larger for 
Table 5-8. Comparison of simulated to measured hydraulic head gradients and flow directions across in the area of each individual WAG and over the site (WAG 10).

\begin{tabular}{|c|c|c|c|c|c|c|c|c|}
\hline \multirow[b]{2}{*}{ WAG } & \multirow[b]{2}{*}{ Wells used } & \multicolumn{3}{|c|}{ Hydraulic gradient } & \multicolumn{3}{|c|}{ Flow direction } & \multirow{2}{*}{$\begin{array}{c}\text { Maximum } \\
\text { distance } \\
\text { between } \\
\text { wells } \\
\text { (ft) }\end{array}$} \\
\hline & & Calculated & Measured & $\begin{array}{l}\text { Percent } \\
\text { difference }\end{array}$ & $\begin{array}{l}\text { Measured } \\
\text { (radius) }\end{array}$ & $\begin{array}{c}\text { Calculated } \\
\text { (radius) }\end{array}$ & $\begin{array}{c}\text { Difference } \\
\text { (radius) }\end{array}$ & \\
\hline \multirow[t]{6}{*}{ Site } & u001 & .000974 & .000968 & .6 & -.457 & -.604 & .147 & 162180. \\
\hline & u023 & & & & & & & \\
\hline & u025 & & & & & & & \\
\hline & u014 & .000785 & .000756 & 3.7 & -.182 & -.105 & -.077 & 209596. \\
\hline & u025 & & & & & & & \\
\hline & $h-2$ & & & & & & & \\
\hline \multirow[t]{3}{*}{ TAN } & u007 & .001030 & .000493 & 52.2 & .565 & .229 & .336 & 28235. \\
\hline & u026 & & & & & & & \\
\hline & anp9 & & & & & & & \\
\hline \multirow[t]{9}{*}{ ANL-W } & arbt & .000785 & .000286 & 63.6 & -1.101 & -.623 & -.478 & 22949. \\
\hline & u002 & & & & & & & \\
\hline & u101 & & & & & & & \\
\hline & $\mathrm{u} 002$ & .000786 & .000500 & 36.4 & -1.004 & -.045 & -.959 & 63288. \\
\hline & u021 & & & & & & & \\
\hline & arbt & & & & & & & \\
\hline & arbt & .000833 & .000762 & 8.5 & -.733 & .151 & -.884 & 61724. \\
\hline & u001 & & & & & & - & \\
\hline & u002 & & & & & & & \\
\hline \multirow[t]{6}{*}{ NRF } & u097 & .000726 & .000627 & 13.6 & .507 & -.239 & .746 & 20204. \\
\hline & u017 & & & & & & & \\
\hline & u012 & & & & & & & \\
\hline & u097 & .000619 & .000689 & -11.3 & -.061 & -.509 & 448 & 42379. \\
\hline & u005 & & & & & & & \\
\hline & u012 & & & & & & & \\
\hline \multirow[t]{3}{*}{ TRA } & mert & .000113 & 001032 & -811.1 & -359 & -.744 & .386 & 5552. \\
\hline & u076 & & & & & & & \\
\hline & u079 & & & & & & & \\
\hline \multirow[t]{3}{*}{ ICPP } & u039 & .000227 & .001122 & -395.3 & .053 & -.610 & .664 & 5745. \\
\hline & u040 & & & & & & & \\
\hline & u077 & & & & & & & \\
\hline
\end{tabular}


Table 5-8. (continued).

\begin{tabular}{|c|c|c|c|c|c|c|c|c|}
\hline \multirow[b]{2}{*}{ WAG } & \multirow[b]{2}{*}{ Wells used } & \multicolumn{3}{|c|}{ Hydraulic gradient } & \multicolumn{3}{|c|}{ Flow direction } & \multirow{2}{*}{$\begin{array}{l}\text { Maximum } \\
\text { distance } \\
\text { between } \\
\text { wells } \\
\text { (ft) }\end{array}$} \\
\hline & & Calculated & Measured & $\begin{array}{c}\text { Percent } \\
\text { difference }\end{array}$ & $\begin{array}{c}\text { Measured } \\
\text { (radius) }\end{array}$ & $\begin{array}{c}\text { Calculated } \\
\text { (radius) }\end{array}$ & $\begin{array}{l}\text { Difference } \\
\text { (radius) }\end{array}$ & \\
\hline CFA & $\begin{array}{l}\text { u039 } \\
\text { u106 } \\
\text { u020 }\end{array}$ & .000378 & .000995 & -163.4 & .012 & -.600 & .612 & 26695. \\
\hline PBF & $\begin{array}{l}\text { s-09 } \\
\text { u005 } \\
\text { u020 }\end{array}$ & .000556 & .000745 & -34.0 & -.585 & -.347 & -.237 & 30269. \\
\hline EBR-I & $\begin{array}{l}u 039 \\
u 087 \\
u 106\end{array}$ & .001395 & .000992 & 28.9 & -1.789 & -.351 & -1.439 & 32975. \\
\hline RWMC & $\begin{array}{l}u 009 \\
u 089 \\
\text { u087 }\end{array}$ & .000269 & .000139 & 48.1 & -.122 & -.713 & .591 & 18381. \\
\hline
\end{tabular}


Table 5-9. Comparison of simulated to measured hydraulic head gradients and flow directions. at the intermediate scale in the vicinity of WAGs 2 through 7.

\begin{tabular}{|c|c|c|c|c|c|c|c|}
\hline \multirow[b]{2}{*}{ Wells used } & \multicolumn{3}{|c|}{ Hydraulic gradient } & \multicolumn{3}{|c|}{$\begin{array}{l}\text { Flow direction } \\
\text { (radians) }\end{array}$} & \multirow{2}{*}{$\begin{array}{l}\text { Maximum distance } \\
\text { between wells } \\
\text { (ft) }\end{array}$} \\
\hline & Calculated & Measured & difference & Measured & Calculated & Difference & \\
\hline u011 & .000742 & .000600 & 19.2 & .020 & -.125 & .145 & 101605. \\
\hline \multicolumn{8}{|l|}{ u097 } \\
\hline \multicolumn{8}{|l|}{$\mathrm{cr}-\mathrm{g}$} \\
\hline $\mathrm{cr}-\mathrm{g}$ & .000976 & .000793 & 18.8 & -.757 & -.764 & .007 & 71819. \\
\hline \multicolumn{8}{|l|}{ u022 } \\
\hline \multicolumn{8}{|l|}{ u097 } \\
\hline u005 & .000678 & .000663 & 2.2 & -.357 & -.636 & .279 & 89430. \\
\hline \multicolumn{8}{|l|}{$\mathrm{u} 10 \overline{5}$} \\
\hline \multicolumn{8}{|l|}{ u086 } \\
\hline $\mathrm{cr}-\mathrm{g}$ & .000607 & .000568 & 6.4 & -.050 & -.152 & .101 & 82118. \\
\hline \multicolumn{8}{|l|}{ mtrt } \\
\hline \multicolumn{8}{|l|}{ u011 } \\
\hline u005 & .000538 & .000580 & -7.8 & -.664 & $-r .242$ & .578 & 105436. \\
\hline \multicolumn{8}{|l|}{ u011 } \\
\hline \multicolumn{8}{|l|}{ u086 } \\
\hline u022 & .000724 & .000692 & 4.5 & -.674 & -.731 & .057 & 63584. \\
\hline \multicolumn{8}{|l|}{$\mathrm{cr}-\mathrm{g}$} \\
\hline \multicolumn{8}{|l|}{ u005 } \\
\hline u011 & .000692 & .000551 & 20.3 & -.115 & -.502 & .387 & 105436. \\
\hline \multicolumn{8}{|l|}{ u097 } \\
\hline \multicolumn{8}{|l|}{ u005 } \\
\hline \multicolumn{8}{|l|}{ u086 } \\
\hline u086 & .000654 & .000721 & -10.3 & -.300 & -.592 & .293 & 58235. \\
\hline \multicolumn{8}{|l|}{ mtrt } \\
\hline $\mathrm{cr}-\mathrm{g}$ & & & & & & & \\
\hline
\end{tabular}


the third. The flow direction is off by -0.48 radians $\left(27^{\circ}\right)$ for the first, -0.96 $\left(55^{\circ}\right)$ for the second, and $-0.88\left(51^{\circ}\right)$ for the third.

- In the Naval Reactors Facility area, two different sets of wells were used to compare the gradients and flow direction. The calculated gradient is $14 \%$ larger for the first and $11 \%$ smaller for the second. The flow direction is off by 0.75 radians $\left(43^{\circ}\right)$ for the first and 0.45 $\left(26^{\circ}\right)$ for the second.

- In the Test Reactor Area, the calculated gradient is 10 times smaller for the simulated hydraulic head estimates than the measured hydraulic head values, and the flow direction is off by 0.39 radians $\left(22^{\circ}\right)$.

- In the Idaho Chemical Processing Plant area, the calculated gradient is five times smaller for the simulated hydraulic head estimates than the measured hydraulic head values, and the flow direction is off by 0.66 radians $\left(38^{\circ}\right)$.

- In the Central Facilities Area, the calculated gradient is three times smaller for the simulated hydraulic head estimates than the measured hydraulic head values, and the flow direction is off by 0.61 radians $\left(35^{\circ}\right)$.

- In the Power Burst Facility area, the calculated gradient is 34\% smaller for the simulated hydraulic head estimates than the measured hydraulic head values, and the flow direction is off by -0.24 radians $\left(14^{\circ}\right)$.

- In the Experimental Breeder Reactor-I area, the calculated gradient is $29 \%$ larger for the simulated hydraulic head estimates than the measured hydraulic head values, and the flow direction is off by -1.44 radians $\left(82^{\circ}\right)$.

- In the Radioactive Waste Management Complex area, the calculated gradient is $48 \%$ larger for the simulated hydraulic head estimates than the measured hydraulic head values, and the flow direction is off by 0.59 radians $\left(34^{\circ}\right)$.

For well triplets chosen near the WAGs, there are large gradient and flow direction differences between those calculated with the simulation model and those calculated with the measured heads. This implies that the scale represented by the well triplets is not sufficiently well defined by the regional model. To estimate the scale at which the current model can be used to accurately define an average gradient and flow direction, eight well triplets were chosen that bound the area of the Test Reactor Area, Idaho Chemical Processing Plant, Central Facilities Area, Power Burst Facility, Experimental Breeder Reactor-I and Radioactive Waste Management Complex WAGs (intermediate scale).

The hydraulic gradient and flow direction comparisons for the eight well triplets are shown in Table 5-9. The maximum distance between the well triplets ranges from 58,235 to $105,436 \mathrm{ft}$ ( 11 to $20 \mathrm{mi}$ ). The gradient percent differences range from -8 to $20 \%$. The flow direction differences range from 0.007 to 0.58 radians $\left(0.4^{\circ}\right.$ to $\left.33^{\circ}\right)$. The gradient calculated from the measured heads ranges from $5.5 \times 10^{-4}$ to $7.9 \times 10^{-4}$. The gradient calculated from the simulated heads ranges from $5.4 \times 10^{-4}$ to $9.8 \times 10^{-4}$. The flow direction calculated from the measured heads ranges from -0.12 radians ( $7^{\circ}$ west of due south) to -1.24 radians $\left(19^{\circ}\right.$ south of due west). The flow direction calculated from the simulated heads ranges from 0.02 radians ( $1^{\circ}$ east of due south) to -.76 radians ( $2^{\circ}$ south of due southwest). 
The gradients and flow directions estimated at the intermediate scale are much better than the local scale estimates. The results of five out of the eight tests had gradient differences in the $10 \%$ or less range. The other three test had gradients differences near $20 \%$. The results of four out of the eight tests had flow direction differences of less than 0.17 radians $\left(10^{\circ}\right)$. The other four tests had flow direction differences of $16^{\circ}, 17^{\circ}, 22^{\circ}$, and $33^{\circ}$. For the most part, the calibration model meets the gradient calibration target on the scale of 10 to $20 \mathrm{mi}$, where the total hydraulic head range over the area is approximately $64 \mathrm{ft}$.

\subsubsection{Water Budget}

The water budget-related calibration target is to reproduce the steady-state gains to the Snake River between Milner and King Hill by $5 \%$ of the fluxes calculated in the Garabedian model. Table 5-10 summarizes the Snake River gains and losses by river reach shown in Figure 3-3. The current model simulates gains between Milner and King Hill that are 5\% different than the Garabedian simulated gains. Although the overall gains simulated from Milner to King Hill are within the calibration target, the gains and losses along the Snake River are not very well distributed (Table 5-10). For this calibration no effort was made to improve the distribution of gains and losses, under the assumption that the distribution of gains and losses along the Snake River has little effect on the hydraulic head distribution at the INEL. However, the error in the reach from Lorenzo to Lewisville $\left(1,073 \mathrm{ft}^{3} / \mathrm{sec}\right.$ versus $\left.-40 \mathrm{ft}^{3} / \mathrm{sec}\right)$ is very large, indicating that the hydraulic head is being overpredicted by the current model in the area of the North Fork of the Snake River.

The overall difference in the total gain to the Snake River $\left(-8,750 \mathrm{ft}^{3} / \mathrm{sec}\right.$ versus $-8,378 \mathrm{ft}^{3} \mathrm{sec}$ ) between the Garabedian and current model is a result of the difference in the overall water budget for the two models. The current model uses the water budget information from the Spinazola model for the northeastern portion of the domain, and the Spinazola model recharge rate estimate is approximately $500 \mathrm{ft}^{3} / \mathrm{sec}$ less than the Garabedian model estimate in the northeastern portion of the domain.

The stream and drain package portions of the water budget are all from the northeastern portion of the model domain. The Spinazola model estimates $168 \mathrm{ft}^{3} / \mathrm{sec}$ inflow from the northeastern streams to the aquifer, and the current model estimates approximately $150 \mathrm{ft}^{3} / \mathrm{sec}$ inflow (an error of $10.7 \%$ ). The Spinazola model estimates $13.9 \mathrm{ft}^{3} / \mathrm{sec}$ outflow from the aquifer, and the current model estimates $8.5 \mathrm{ft}^{3} / \mathrm{sec}$ (an error of $38.8 \%$ ). The percentage of error for the stream and drain packages are moderate to high, but each error is a small portion of the overall water budget and, therefore, not a major source of calibration error.

\subsubsection{Parameter Value Range}

Table 5-11 compares the calibrated $\mathrm{K}$ values for the current model with the 21 key wells and all 48 observation wells with values used in previous regional groundwater flow modeling studies (Garabedian, Spinazola, EIS, and FY 93 WAG 10) and Test Area North modeling (Schafer-Perini 1992). The location of the zones are shown in Figure 3-16. The range of $K$ values over all of these studies is $8 \times 10^{-4}$ to $5 \mathrm{ft} / \mathrm{sec}$. The range of $\mathrm{K}$ values for the current model is $8 \times 10^{-4}$ to $1 \times 10^{-1}$. The possible $\mathrm{K}$ ranges shown in Table $5-2$ are $3 \times 10^{-7}$ to $1 \times 10^{-1} \mathrm{ft} / \mathrm{sec}$ for basalt and $1 \times 10^{-5}$ to $3 \mathrm{ft} / \mathrm{sec}$ for sand and gravel. Only the K values estimated in the northern part of the INEL for the FY 93 WAG 10 model falls outside the possible range of $K$ values. The 
Table 5-10. Comparison of simulated gains and losses in the Snake River with the measured values and values estimated by Garabedian.

\begin{tabular}{|c|c|c|c|c|}
\hline Reach & $\begin{array}{c}\text { Current } \\
\text { model } \\
\left(\mathrm{ft}^{3} / \mathrm{sec}\right)\end{array}$ & $\begin{array}{c}\text { Garabedian } \\
\text { model } \\
\left(\mathrm{ft}^{3} / \mathrm{sec}\right)\end{array}$ & Percent error & $\begin{array}{c}\text { Measured } \\
\left(\mathrm{ft}^{3} / \mathrm{sec}\right)\end{array}$ \\
\hline Hagerman to King Hill & -1284 & -1530 & 16 & -1410. \\
\hline Buhl to Hagerman & -4458 & -3830 & 16 & -3610 \\
\hline Kimberly to Buhl & -1251. & -1430 & 12 & -1220. \\
\hline Milner to Kimberly & -491 & -100 & 391 & -300 \\
\hline Milner to King Hill & -7484 & -6890 & 8.6 & \\
\hline Minidoka to Milner & -32 & 0. & NA & -130 \\
\hline Neeley to Minidoka & -109 & -20 & 445 & -180 \\
\hline $\begin{array}{l}\text { Near Blackfoot to } \\
\text { Neeley }\end{array}$ & -2427 & -2640 & 8 & -2620 \\
\hline $\begin{array}{l}\text { At Blackfoot to near } \\
\text { Blackfoot }\end{array}$ & 51. & 200. & 74 & 270. \\
\hline Shelley to At Blackfoot & 189. & 160. & 15 & 150. \\
\hline Lewisville to Shelley & 132. & 370. & 64 & 380. \\
\hline Lorenzo to Lewisville & 1073. & -40 & 278 & -290 \\
\hline Heise to Lorenzo & 120. & 180. & 33 & 150. \\
\hline Lower Henry's Fork & 110. & -30 & 466 & -120 \\
\hline $\begin{array}{l}\text { Lower Salmon Falls } \\
\text { Creek }\end{array}$ & -9 & -40 & 77 & 0. \\
\hline Total & -8378 & -8750 & 4 & -8930. \\
\hline
\end{tabular}


Table 5-11. Comparison of layer $1 \mathrm{~K}$ values for the current model and those used for select previous studies.

\begin{tabular}{|c|c|c|c|c|c|c|c|}
\hline $\begin{array}{c}\text { Zone } \\
\text { number }\end{array}$ & $\begin{array}{c}\text { Current } \\
\text { model }(21 \\
\text { key wells) } \\
\left(\times 10^{-3} \mathrm{ft} / \mathrm{s}\right)\end{array}$ & $\begin{array}{c}\text { Current } \\
\text { model (all } \\
48 \mathrm{key} \\
\text { wells }) \\
\left(\times 10^{-3} \mathrm{ft} / \mathrm{s}\right)\end{array}$ & $\begin{array}{c}\text { Garabedian } \\
\text { model } \\
\left(\times 10^{-3} \mathrm{ft} / \mathrm{s}\right)\end{array}$ & $\begin{array}{l}\text { Spinazola } \\
\text { model } \\
\left(\times 10^{-3} \mathrm{ft} / \mathrm{s}\right)\end{array}$ & $\begin{array}{l}\text { EIS model } \\
\left(\times 10^{-3} \mathrm{ft} / \mathrm{s}\right)\end{array}$ & $\begin{array}{l}\text { FY } 93 \text { WAG } \\
10 \text { model } \\
\left(\times 10^{-3} \mathrm{ft} / \mathrm{s}\right)\end{array}$ & $\begin{array}{l}\text { Test Area } \\
\text { North } \\
\text { model } \\
\left(\times 10^{-3} \mathrm{ft} / \mathrm{s}\right)\end{array}$ \\
\hline 51 & 1.70 & 1.71 & 10. & NA & 4. & 12. & NA \\
\hline 52 & 11.2 & 11.20 & 6. & 17. & 1. & 5000 & NA \\
\hline 53 & 5.31 & 4.57 & 100. & NA & 12. & 20. & NA \\
\hline 54 & 57.00 & 58.40 & 100. & NA & 17. & 20. & NA \\
\hline 55 & 52.90 & 56.60 & 100. & $\mathrm{NA}$ & 13. & 70. & NA \\
\hline 56 & 3.64 & 7.03 & 25. & NA & 7. & 17. & NA \\
\hline 57 & 11.60 & 15.60 & 20. & 29. & 8. & 17. & NA \\
\hline 58 & 96.20 & 112.00 & 24. & NA & 8. & 40 & NA \\
\hline 59 & 7.72 & 12.30 & 15. & 10. & 28. & 5000 & 10. \\
\hline 60 & 7.56 & 0.89 & 5. & 10. & 21. & 7. & 1. \\
\hline 61 & 0.82 & 0.83 & 6. & NA & 0.8 & 2. & NA \\
\hline 62 & 1.33 & 1.12 & 10. & NA & 2.3 & 10. & NA \\
\hline 12 & 6.20 & 6.76 & 2.2 & NA & 7.5 & 5. & NA \\
\hline
\end{tabular}


current model results all fall well within the acceptable range of $\mathrm{K}$ values.

\subsubsection{Parameter Reliability}

MODFLOWP calculates a coefficient of variation as an indicator of the reliability of the parameter value. Table 5-4 lists the coefficients of variation along with the parameter estimates. The coefficient of variation is less than 1 for all the parameter estimation zones except 54 (1.33), 56 (1.08), 58 (1.11), 59 (1.32), and 60 (2.38) for the calibration run using the 21 key wells and zone 60 (1.76) for the calibration run using all 48 wells. The parameter estimates for these zones are not very reliable primarily because there are a lot of zones defined in the northern portion of the INEL and fairly few hydraulic head observations constraining the hydraulic head solution. 


\section{SENSITIVITY ANALYSIS}

The groundwater flow model developed is a useful tool for evaluating regional flow in the vicinity of the INEL, but results inferred from the model must be evaluated with respect to their sensitivity to various parameters. The sensitivity of the model to each parameter is a function of the magnitude of the sensitivity coefficients, the areal distribution of the sensitivity coefficients, and the possible range over which the parameter can vary. This section quantifies the uncertainty in predictions to the most important inputs to the model. The sensitivity analysis was performed for

- Hydraulic conductivity values for each $K$ zone used for calibration (Section 6.1)

- Estimated underflows from tributary drainage basins (Section 6.2)

- Conductances of the Snake River, vertical hydraulic conductivity, recharge and pumping over the entire domain (Section 6.3).

To evaluate the sensitivity of the hydraulic heads at the different WAGs to the input parameters of interest, one finite difference grid was assigned to represent each of the nine WAG-specific wells. The grids chosen are shown in Table 6-1. Sections 6.1, 6.2, and 6.3 show the sensitivity values for the WAGspecific wells.

The MODFLOWP capability to calculate sensitivity coefficients was used for the K, underflow, Snake River conductances, and pumping sensitivity calculations. These sensitivity coefficients are calculated using the sensitivity equation method (Hill 1992), which calculates the rate of change of the head for an infinitesimally small change in the parameter value. The numerical value of a sensitivity coefficient is the expected change in the calculated hydraulic head if the parameter value is doubled. The values assume that the heads vary linearly with respect to each of the parameters. Sensitivity coefficients for the vertical $\mathrm{K}$ and recharge were calculated by doubling the input value, generating a new solution, and comparing the hydraulic head values with the original solution.

An important use of the sensitivity analysis is to identify which of the model water budget components needs to be incorporated as transient. Because the primary objective of the current model is to define the regional hydraulic gradient and flow direction, components of the transient water budget must be incorporated when they significantly influence hydraulic gradient values at the INEL.

In this discussion, the term significantly sensitive is used to describe WAGs where the sensitivity coefficient is greater than $3.3 \mathrm{ft}$.

Table 6-1. Sensitivity analysis grids.

\begin{tabular}{lc}
\hline \multicolumn{1}{c}{ WAG } & Row, column \\
\hline WAG 1 (TAN) & $(20,148)$ \\
WAG 2 (TRA) & $(29,128)$ \\
WAG 3 (ICPP) & $(31,128)$ \\
WAG 4 (CFA) & $(33,127)$ \\
WAG 5 (PBF) & $(35,129)$ \\
WAG 6 (EBR-I) & $(32,123)$ \\
WAG 7 (RWMC) & $(32,121)$ \\
WAG 8 (NRF) & $(26,120)$ \\
WAG 9 (ANL-W) & $(36,141)$ \\
\hline
\end{tabular}

\subsection{Hydraulic Conductivity Values}

The sensitivity coefficients for each of the calibration K zones (see Figure 3-16) at each of the WAG areas is shown in Table 6-2. None of the WAG areas is significantly sensitive to the $K$ values in zones $51,56,60$, and 61 . Only the Test Area North area (WAG 1) is significantly 
Table 6-2. Sensitivity coefficients for each $\mathrm{K}$ parameter zone at each of the WAG areas.

\begin{tabular}{|c|c|c|c|c|c|c|c|c|c|}
\hline \multirow[b]{2}{*}{ WAG } & \multicolumn{9}{|c|}{ Sensitivity coefficient } \\
\hline & 1 & 2 & 3 & 4 & 5 & 6 & 7 & 8 & 9 \\
\hline \multicolumn{10}{|c|}{$\begin{array}{c}\text { Hydraulic } \\
\text { conductivity } \\
\text { zone }\end{array}$} \\
\hline 51 & -.212 & -.515 & -.395 & -.273 & -.249 & -.189 & -.060 & -.484 & -.136 \\
\hline 53 & -5.33 & -14.2 & -12.5 & -4.83 & -7.97 & 2.80 & 5.05 & -13.0 & -4.09 \\
\hline 55 & -5.43 & -1.68 & -1.56 & -.157 & -2.89 & 2.79 & 3.69 & -3.34 & -7.67 \\
\hline 56 & -2.52 & -.139 & -.137 & .065 & -.212 & .495 & .538 & -1.12 & -.320 \\
\hline 57 & -12.6 & 9.81 & 10.9 & 8.43 & 8.99 & 5.58 & 4.89 & .655 & 4.80 \\
\hline 54 & -1.85 & .492 & .229 & .488 & -1.14 & 3.11 & 4.20 & -.468 & -2.86 \\
\hline 60 & -1.24 & .134 & .136 & .131 & .143 & .119 & .115 & .131 & .213 \\
\hline 58 & -2.16 & 5.67 & 6.02 & 6.67 & 6.82 & 6.87 & 6.94 & 4.71 & 2.79 \\
\hline 59 & -4.17 & .189 & .176 & .140 & .160 & .102 & .089 & .251 & .169 \\
\hline 12 & -11.2 & -15.3 & -15.2 & -15.7 & -14.2 & -17.7 & -18.5 & -14.3 & -11.5 \\
\hline 62 & -43.6 & 2.31 & 2.07 & 1.57 & 1.77 & 1.10 & .940 & 3.44 & 1.68 \\
\hline 61 & -.315 & .144 & .093 & .060 & .043 & .053 & .040 & .155 & -.009 \\
\hline Totals & -77.14 & -13.09 & -6.48 & -6.64 & -6.40 & -6.35 & -6.18 & -6.08 & -9.52 \\
\hline
\end{tabular}


sensitive to the $K$ value in zone 59. Only the Test Area North and Naval Reactors Facility areas (WAGs 1 and 8) are significantly sensitive to the $K$ value in zone 62 .

All WAGs are significantly sensitive to the $K$ value in zone 12, a zone defined in the Garabedian model downgradient from the INEL that is positioned perpendicular to the direction of flow. Therefore, changes in the $\mathrm{K}$ value in zone 12 increase or decrease (fairly uniformly) the hydraulic head over the entire INEL. All WAGs but Test Area North are significantly sensitive to the $K$ value in zone 58. All WAGs but Central Facilities Area are significantly sensitive to the $K$ value in zone 53. All WAGs but Naval Reactors Facility are significantly sensitive to the $K$ value in zone 57. Approximately one half of the WAG areas are significantly sensitive to the $K$ value in zone 55 .

The distribution of the $\mathrm{K}$ sensitivities is not uniform over the INEL, which implies that the hydraulic gradient is sensitive to the $K$ values. This hydraulic gradient sensitivity is not quantified in this report, but it may need to be quantified before using the model to define the boundary conditions for a facility-specific WAG model. The possible range over which $K$ can vary is very large (Table 5-2).

\subsection{Boundary Conditions- Underflows}

The sensitivity coefficients at each of the WAG areas to the underflow fluxes from each drainage basin are shown in Table 6-3. Table 6-3 lists the drainage basins in the INEL area from the basin with the highest sensitivity coefficient to the lowest. The hydraulic head in the area of the INEL is only significantly sensitive to the underflows from the Big Lost River, Little Lost River, and Birch Creek drainage basins. Figures 6-1, 6-2, and 6-3 are sensitivity maps for the underflows from the Big Lost River, Little Lost River, and
Birch Creek drainage basins. The Test Area North area is 2 to 10 times as sensitive to the underflow estimates from the Little Lost River and Birch Creek drainage basins than the other WAG areas.

The underflow sensitivity coefficients for the Big Lost River, Little Lost River, and Birch Creek drainage basins are similar in magnitude to the $\mathrm{K}$ sensitivity coefficients. However, the possible range of $\mathrm{K}$ values (several orders of magnitude) is much higher than the possible range of underflow values. Based on the water balance estimates shown in Table $3-8,18$ to $20 \%$ of the total precipitation falling outside the current model domain but inside the Big Lost River, Little Lost River, and Birch Creek drainage basins is assumed to enter the aquifer as underflow. Although it is possible that the underflow is significantly overestimated, it is unlikely that it is either overestimated or underestimated by more than a factor of 2 . Therefore, hydraulic head at the INEL is sensitive to the underflow from the Big Lost River, Little Lost River, and Birch Creek drainage basins, but the possible hydraulic head error because of inaccurate underflow estimates is small relative to the possible error from inaccurate $\mathrm{K}$ estimates.

The distributions of the underflow sensitivities for the Big Lost River, Little Lost River, and Birch Creek drainage basins are not uniform over the INEL. These sensitivities imply that the hydraulic gradient is sensitive to the underflows; therefore, they are important components in a transient flow model of INEL and were incorporated into the transient version of the current model.

Based on the results of the drainage basin underflow sensitivity analysis, transient water budgets must be defined for the Big Lost River, Little Lost River, and Birch Creek drainage basin underflows to develop a 
Table 6-3. Sensitivity coefficients for each underflow area at each of the WAG areas.

\begin{tabular}{|c|c|c|c|c|c|c|c|c|c|c|}
\hline \multirow[b]{2}{*}{ WAG } & \multicolumn{10}{|c|}{ Sensitivity coefficient } \\
\hline & 1 & 2 & 3 & 4 & 5 & 6 & 7 & 8 & 9 & \\
\hline Underflow zone & & & & & & & & & & Sum \\
\hline Big Lost River & 6.35 & 10.2 & 9.74 & 9.74 & 8.49 & 11.5 & 12.2 & 9.29 & 6.31 & 83.82 \\
\hline Little Lost River & 21.1 & 10.1 & 8.65 & 6.70 & 6.96 & 5.2 & 4.48 & 13.9 & 5.35 & 82.44 \\
\hline Birch $\mathrm{Cr}$ & 28.3 & 3.80 & 3.50 & 2.92 & 3.17 & 2.36 & 2.15 & 4.86 & 3.26 & 54.32 \\
\hline Camas $\mathrm{Cr}$ & 2.32 & 1.15 & 1.13 & 1.06 & 1.13 & .966 & .932 & 1.24 & 1.28 & 11.21 \\
\hline Big Bend Ridge Area & 1.67 & .869 & .854 & .805 & .856 & .734 & .709 & .937 & .968 & 8.40 \\
\hline Silver $\mathrm{Cr}$ & .625 & .833 & .827 & .845 & .777 & .932 & .967 & .789 & .646 & 7.24 \\
\hline $\begin{array}{l}\text { Warm Springs and Deep } \\
\text { Creeks }\end{array}$ & 3.37 & .539 & .504 & .434 & .469 & .362 & .335 & .664 & .496 & 7.17 \\
\hline Raft River & .427 & .561 & .557 & .568 & .527 & .620 & .641 & .533 & .445 & 4.88 \\
\hline Beaver $\mathrm{Cr}$ & .960 & .440 & .431 & .404 & .430 & .366 & .353 & .478 & .485 & 4.35 \\
\hline Portneuf River & .336 & .400 & .402 & .408 & .402 & .415 & .417 & .393 & .383 & 3.56 \\
\hline Willow $\mathrm{Cr}$ & .433 & .332 & .328 & .314 & .333 & .290 & .282 & .349 & .379 & 3.04 \\
\hline Salmon Falls $\mathrm{Cr}$ & .215 & .285 & .283 & .289 & .266 & .317 & .328 & .271 & .222 & 2.48 \\
\hline Little Wood River & .208 & .277 & .275 & .281 & .259 & .310 & .321 & .263 & .215 & 2.41 \\
\hline Bannock $\mathrm{Cr}$ & .200 & .241 & .243 & .247 & .241 & .254 & .256 & .236 & .226 & 2.14 \\
\hline Blackfoot River & .218 & .217 & .217 & .212 & .221 & .202 & .198 & .222 & .241 & 1.95 \\
\hline Rockland Valley & .162 & .200 & .200 & .204 & .196 & .214 & .217 & .194 & .177 & 1.76 \\
\hline Rexburg Bench & .247 & .158 & .155 & .148 & .157 & .135 & .131 & .168 & .178 & 1.48 \\
\hline Big Wood River & .078 & .103 & .102 & .105 & .096 & .115 & .119 & .098 & .080 & 0.90 \\
\hline Fish $\mathrm{Cr}$ & .074 & .099 & .098 & .101 & .092 & .112 & .116 & .094 & .076 & 0.86 \\
\hline Goose $\mathrm{Cr}$ & .057 & .075 & .075 & .076 & .070 & .084 & .087 & .071 & .059 & 0.65 \\
\hline Snake River & .094 & .065 & .064 & .061 & .065 & .056 & .054 & .069 & .074 & 0.60 \\
\hline Medicine Lodge $\mathrm{Cr}$ & .141 & .058 & .056 & .052 & .056 & .047 & .046 & .063 & .063 & 0.58 \\
\hline Henry's Fork Snake & .044 & .024 & .023 & .022 & .024 & .020 & .020 & .026 & .027 & 0.23 \\
\hline Thorn $\mathrm{Cr}$ & .018 & .024 & .024 & .024 & .022 & .027 & .028 & .023 & .019 & 0.21 \\
\hline $\begin{array}{l}\text { Cottonwood, Rock, and } \\
\text { Dry Creeks }\end{array}$ & .017 & .023 & .022 & .023 & .021 & .025 & .026 & .021 & .017 & 0.20 \\
\hline $\begin{array}{l}\text { Lincoln and Ross Fork } \\
\text { Creeks }\end{array}$ & .014 & .016 & .016 & .016 & .016 & .017 & .017 & .016 & .016 & 0.14 \\
\hline Clover $\mathrm{Cr}$ & .008 & .011 & .011 & .011 & .010 & .012 & .013 & .011 & .009 & 0.10 \\
\hline
\end{tabular}




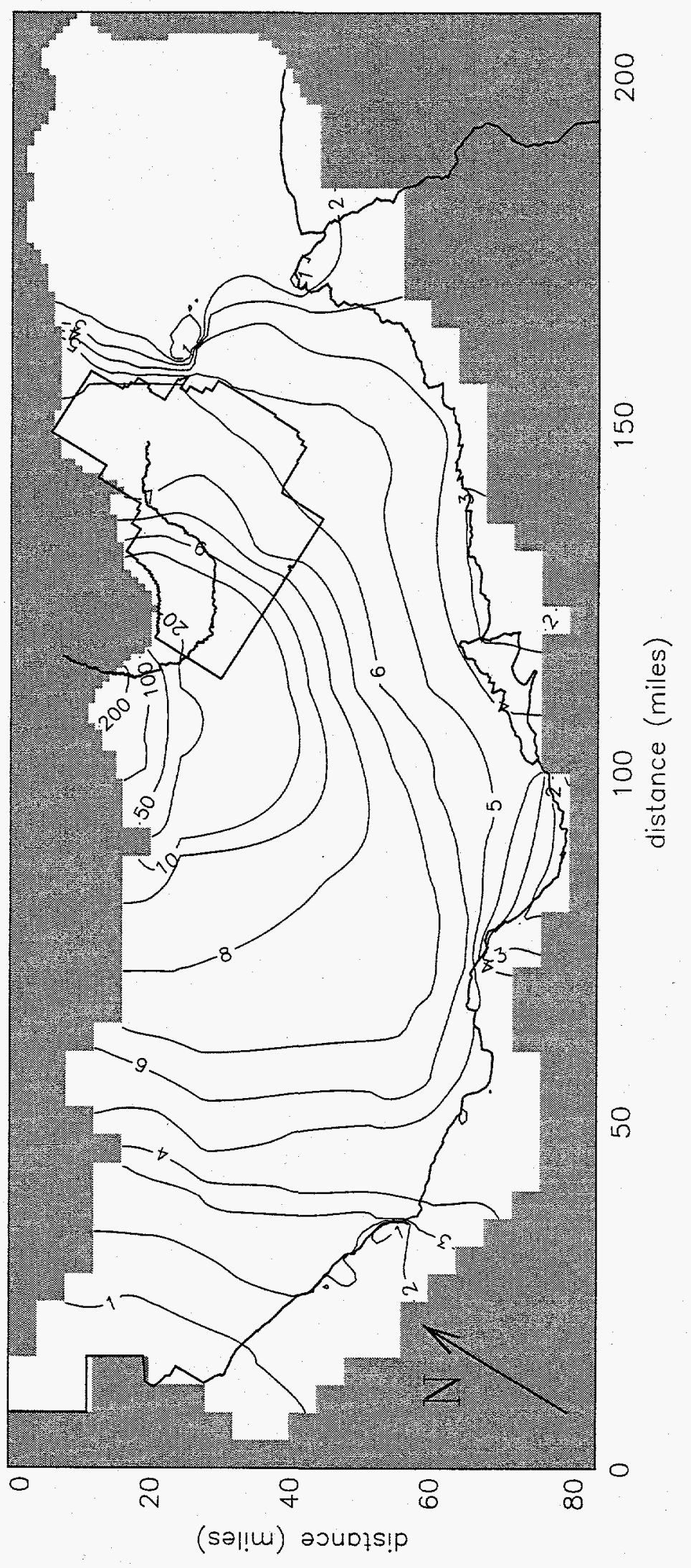

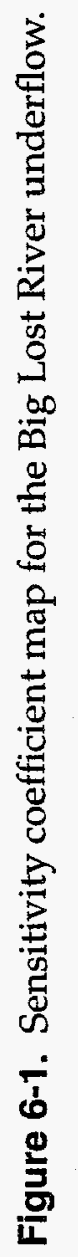




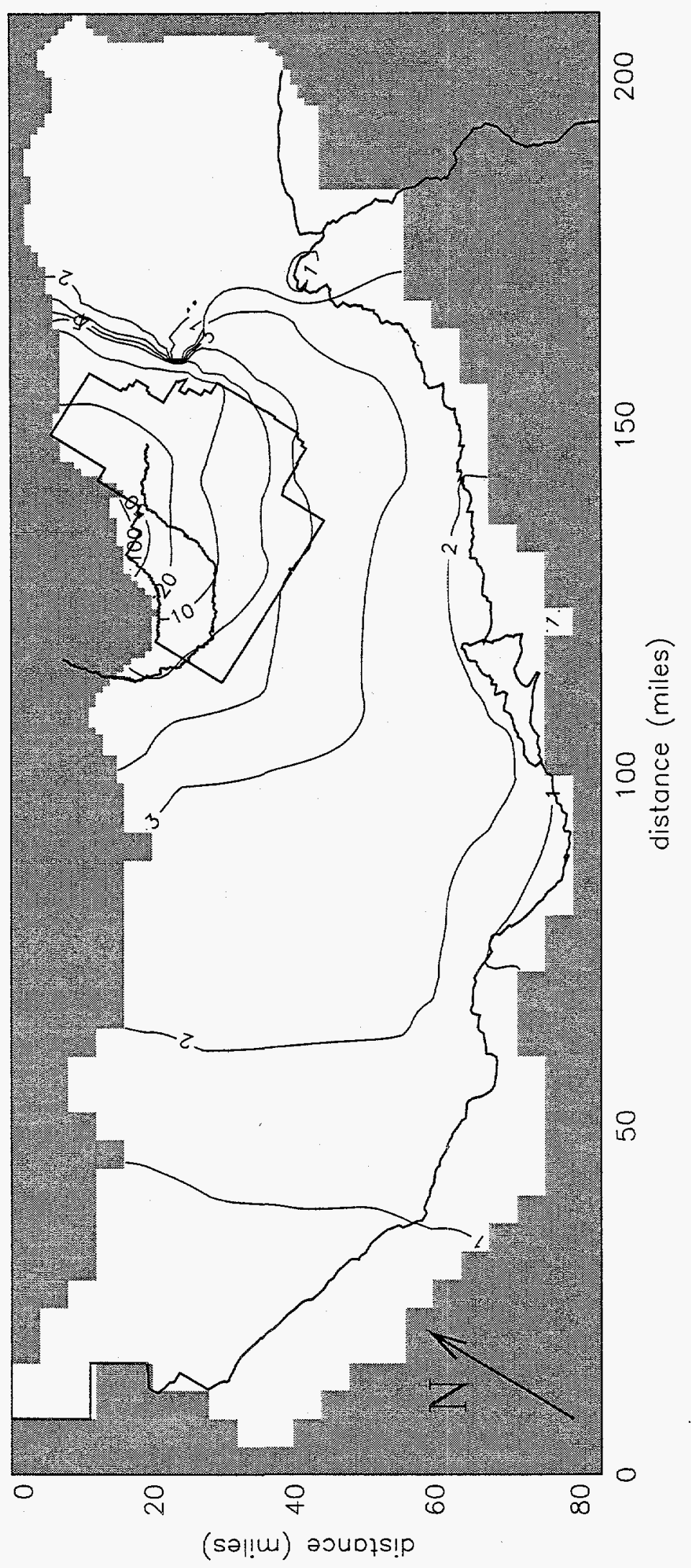

 


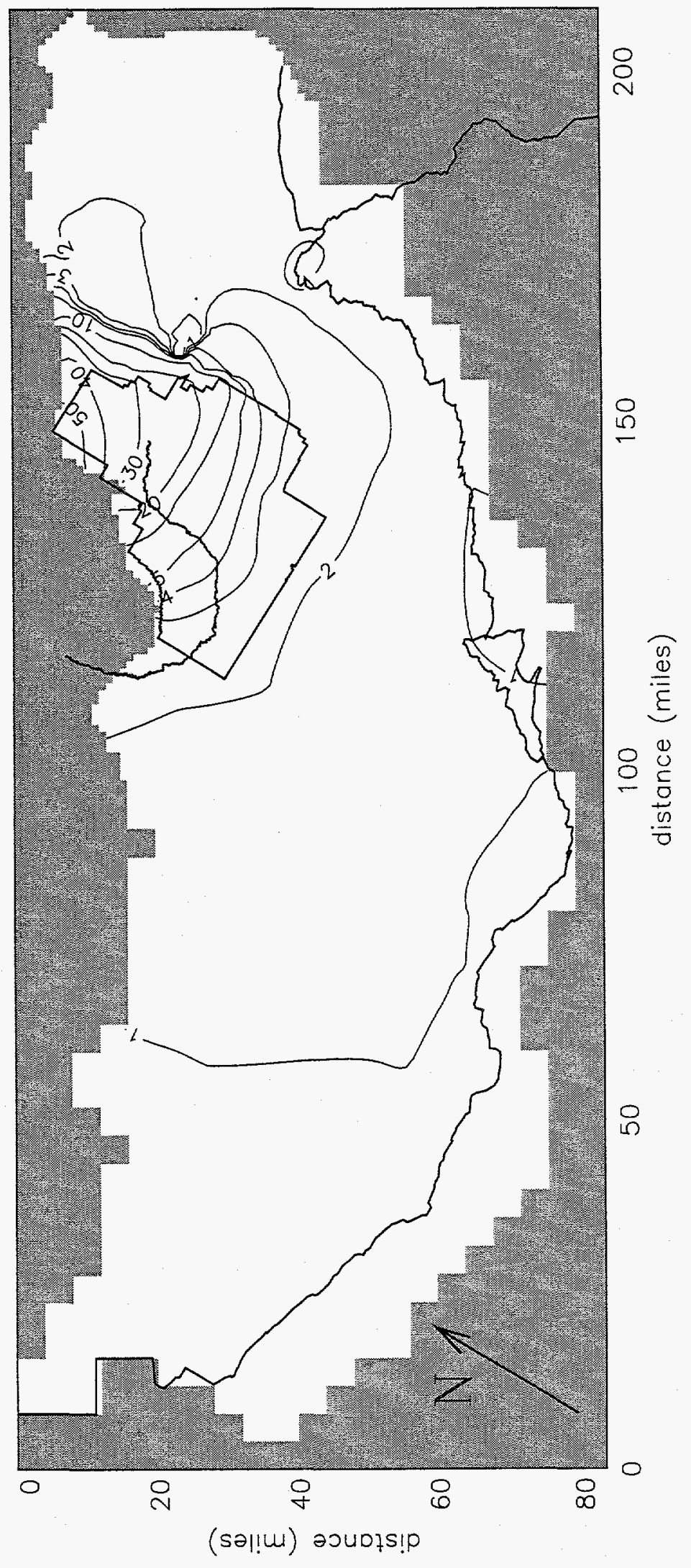

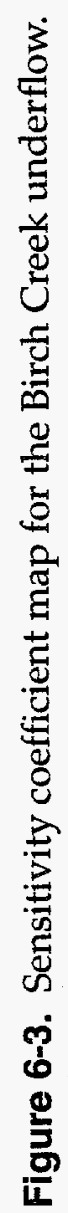


transient flow model representative of the regional flow in the area of the INEL. Because the INEL area is relatively insensitive to the underflow from all other drainage basins, the steady-state and transient models can be represented by steady-state underflow.

\subsection{River Conductances, Vertical Hydraulic Conductivity, Recharge, and Pumping}

Table 6-4 shows the sensitivity coefficients at each of the WAG areas to the Snake River conductances, vertical hydraulic conductivity, recharge, and pumping. The sensitivity coefficients for river conductance, vertical hydraulic conductivity, and pumping are all of the same order of magnitude, and the sensitivity coefficients for the recharge are an order of magnitude higher.

The relatively large sensitivity coefficients for recharge and pumping near Test Area North imply that a transient representation of these two water budget components may be necessary for a transient flow model. However, because the current model will be used primarily to define flow directions and gradients, a transient representation of the recharge and pumping is only necessary if the hydraulic gradient is significantly sensitive. The uniform distribution of the recharge and pumping sensitivities (except to pumping near Test Area North) implies a low hydraulic gradient and direction sensitivity to these water budget components. It may be necessary to test the Test Area North area sensitivity to pumping and recharge in the Mud Lake area to accurately model transient flow in that area.

Although the sensitivity coefficients are of the same (or higher) order of magnitude as the $K$ and underflow sensitivities (higher for recharge), two reasons explain why these sensitivities are not as significant to the regional modeling as the $\mathrm{K}$ sensitivities:

1. The sensitivities to all four parameters (river conductance, vertical hydraulic conductivity, recharge, and pumping) are relatively uniform, implying that the gradient sensitivity is small with the possible exception of Test Area North and Argonne National Laboratory-West areas that are relatively far from the other WAGs.

2. The magnitude of the water budget parameters (recharge and pumping) are relatively well defined in comparison to the K estimates. Although there is significant uncertainty in the magnitude of recharge from precipitation and irrigation with respect to the overall water budget, the possible range of the recharge values is very small compared to the K estimates. Similarly, the possible range of magnitudes of pumping is very restricted. 
Table 6-4. Sensitivity coefficients for the river conductance, vertical hydraulic conductivity, recharge, and pumping at each WAG area.

\begin{tabular}{ccccc}
\hline & \multicolumn{4}{c}{ Sensitivity coefficient } \\
\cline { 2 - 5 } WAG & $\begin{array}{c}\text { Snake River } \\
\text { conductances }\end{array}$ & $\begin{array}{c}\text { Vertical hydraulic } \\
\text { conductivity }\end{array}$ & Recharge & Pumping \\
\hline 1 & -4.18 & -3 & 54 & -22.0 \\
2 & -10.8 & -5 & 47 & -13.4 \\
3 & -10.9 & -5 & 46 & -13.3 \\
4 & -11.7 & -5 & 45 & -13.1 \\
5 & -10.5 & -5 & 45 & -12.9 \\
6 & -13.1 & -6 & 45 & -13.2 \\
7 & -13.6 & -6 & 46 & -13.3 \\
8 & -9.81 & -5 & 47 & -13.7 \\
9 & -7.86 & -4 & 45 & -12.6 \\
\hline
\end{tabular}





\section{MODEL LIMITATIONS}

The objective of developing the current model is to create a tool for defining regional flow at the INEL for use in simulating contaminant transport in the vicinity of facility-specific WAGs. A submodel used to simulate contaminant transport in the vicinity of the facility-specific WAG can use flux information generated from the calibrated regional model along the submodel boundary (described in Chapter 9). To meet the model objective, a number of key modeling assumptions and simplifications were made that limit the usefulness of the calibrated model. This chapter summarizes the major limitations.

The regional-scale water budget should be accurate enough to estimate reasonable average linear groundwater velocities. To ensure the current model's overall water budget was reasonable, the aquifer domain was chosen to extend to the ESRP boundaries. The large size of the domain restricts the ability to define detailed water budget or geological features. Therefore, the water budget components are relatively large-scale averages, and the $1 \times 1-\mathrm{mi}$ numerical grid is relatively large scale. The hydraulic gradient and flow directions obtained from the simulation model are not necessarily accurate over the small scale, which is a limitation of this large-scale model. Therefore, a submodel must be chosen large enough so that the errors in the hydraulic gradient and flow direction defined by the regional model meet the requirements of the submodel.

The calibration was performed for only the upper $200 \mathrm{ft}$ of the aquifer because it is assumed that the contaminant plumes are transported primarily in that portion of the aquifer. To simulate only a portion of the total water budget moving through the upper $200 \mathrm{ft}$ of the aquifer, the current model vertically distributes the total water flux between the upper portion of the aquifer where the contaminant plumes exist and the deeper portions that do not actively transport contaminants.

A multi-layer model is needed to vertically distribute the water and calibrate only over the upper $200 \mathrm{ft}$ of the aquifer. The vertical conductance between the model layers parameter is used to allow exchange of water between layers. Because very little information is available regarding vertical flow and calibration of the aquifer deeper than $200 \mathrm{ft}$ does not exist, the definition of the vertical conductance between model layers is very simplified: Vertical conductance is assumed to be uniform between any two layers and equal to the value defined in the Spinazola model. By only calibrating the simulated hydraulic head in the upper layer of the model, the simulated hydraulic heads for the other layers may not represent actual hydraulic heads.

This regional model will be used to define the regional flow setting for submodels in the vicinity of the facility-specific WAGs. Therefore, the calibration can be focused on observation wells in the vicinity of facilityspecific wells. Because the calibration focuses on the WAG areas, parameter zones and values used in the Garabedian and Spinazola models were assumed to be adequate for use in the current model for areas outside the vicinity of the INEL. A limitation to this assumption is that the parameter changes necessary to calibrate the model in the vicinity of the INEL also affect the hydraulic head calculations in the rest of the model domain. Calibration was not performed on the rest of the domain; therefore, the simulated hydraulic heads outside the area of the INEL are not necessarily accurate and require additional calibration for accuracy.

The transient flow model developed is very simplified. It incorporates quarterly transient 
underflow from the Big Lost River, Little Lost River, and Birch Creek drainage basins but defines all other water budget components as steady state. It also applies one homogeneous storage coefficient to the upper layer and another to the lower three layers. Therefore, if the sensitivity to other water budget components or to the spatial variability of storage coefficients is needed, modifications to the transient model input files are needed.

The calibrated hydraulic conductivity values are applicable for the current model designed, but the values are not necessarily appropriate if the regional model is modified or for a smaller scale model. Therefore, if the water budget or the calibration objectives change, the model would need to be recalibrated.

The current model is appropriate for defining the regional flow setting for flow submodels as well as hypothesis testing to better understand the regional groundwater flow in the area of the INEL. The scale of the submodels must be chosen based on the accuracy required for the study being performed (see Chapter 9). There is not a fixed required minimum model size.

The regional model calculates the regional gradient and flow direction, but the porosity must also be known to calculate the average linear velocity. PATH3D, a particle tracking code, was purchased and tested for this study to help calibrate the average linear velocity. PATH3D was not used with the current model, but it is available to help local-scale WAGs understand the velocity distribution being simulated by the regional model.

The input structure for the MODFLOWP Parameter Estimation Package is user friendly and versatile. During fiscal year 1994, Dr. Mary Hill, the author of MODFLOWP, updated her code and addressed some of the deficiencies identified during this study. A major difference between MODFLOW and MODFLOWP is that MODFLOW can incorporate many wells in one numerical grid, while MODFLOWP requires that only one well be defined for each grid (this is not documented in the MODFLOWP manual). For this study, when limited to one well per grid, the Well Package input file for the current model combines pumping well, tributary basin underflow, and stream and canal leakage.

In many cases, several of the well file components are located in the same numerical grid. The magnitudes of different well components must be added together to be used with MODFLOWP. After the components are added, the input file loses the detail necessary to separate the different water budget components for the model. Therefore, future modelers will find it difficult to reconstruct the water budget on which the model was based.

It is a common misconception that the input files for a parameter estimation code, such as MODFLOWP, only need to be defined and then the code generates a calibrated model and the study is complete. A groundwater numerical model is a very complicated mathematical description of reality, and many parameters interact to provide a final solution. It is a long process to assemble all the information necessary to accurately set up the input file. Therefore, modelers must test different input information (such as hydraulic parameter zones) to create a model that meets the objectives of their studies. In this role, MODFLOWP is a powerful tool that combines trial and error with automatic parameter estimation. 


\section{MODELING AND EVALUATION TOOLS}

Tools were developed to evaluate data applicable to the current groundwater flow model. This chapter provides information about these tools. Appendix B describes each tool and its input files, methodology, screen output, output files, and user interface.

Six tools were developed with the PV-WAVE program (Visual Numerics 1993) for visual analysis of MODFLOWP input and output files. These tools were used during model calibration to graphically represent the results. A PV-WAVE program can be used to create a new $\mathrm{K}$ zone matrix file for MODFLOWP based on existing $\mathrm{K}$ zones and user input. Other PV-WAVE programs display MODFLOWP results including calculated head contours, contours of sensitivity to various parameters, calculated heads compared with Garabedian or Spinazola model results, and calculated heads compared between two MODFLOWP runs.

\section{A PV-WAVE code was developed to view} three-dimensional static and dynamic data. The code was used during the current study to view aquifer temperature as a function of depth and identify regional flow areas based on similarity in temperature. In general, a three-dimensional plot of aquifer temperature versus depth shows temperatures are warmer in the northeast than the southwest area of the INEL (Figure 8-1). Additional analysis of the temperature data was not conducted.

A local-scale hydraulic gradient can be calculated using head data from three wells. These calculations can determine the applicability of the regional model to the local scale. A tool was developed to calculate the hydraulic gradient and flow direction for three wells and plot the results. This tool calculated measured and simulated hydraulic gradients for each WAG as discussed in Section 5.2.2.

A Hypercard application was used as a bibliography for references used in the WAG 10 Modeling Project. For each reference, the bibliography application contains an information card similar to a card in a card catalog. The application can sort the information cards, export bibliographies, and count reports in various categories.

Hydraulic head measurements in wells fluctuate based on changes in hydrologic conditions such as recharge and pumping. Wells that are affected by the same hydrologic condition should show similar fluctuations in hydraulic head. These fluctuations may be attenuated in space or lagged over time; therefore, they may not be apparent by comparing hydrographs. However, correlation analysis of the hydraulic head in wells may show areas of similar hydrologic response.

Two correlation analyses were conducted. The first analysis compared heads in pairs of wells. Because this type of analysis does not account for time-lagged data, correlation results were inconclusive. The second type of analysis compared the results of the Fast Fourier Transform of hydraulic head data for wells at the INEL. Using this method, correlation between wells can be determined independent of time. PV-WAVE programs were developed to compute the spline fit for hygrographs for all wells, compute the Fast Fourier Transform of the spline fit, compute the correlation of Fast Fourier Transform results, and plot the results. Strong correlation patterns were not detected in a preliminary analysis of the results. Further analysis was not conducted. 



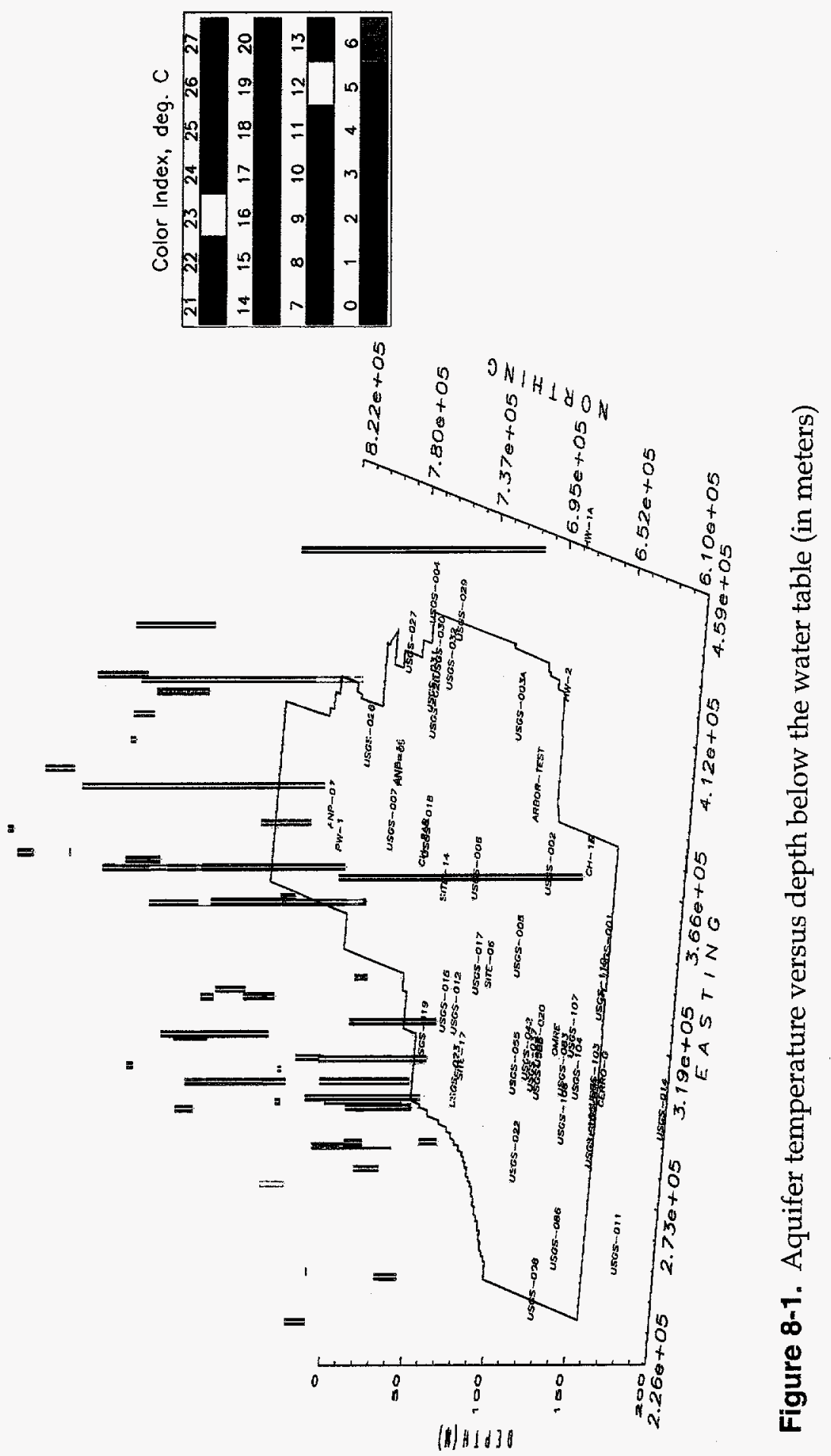


Estimates of groundwater velocity are a useful adjunct to the flow modeling for nonsorbed constituents, movement is often dominated by advective velocity, which is obtained in part from the flow model. The average linear pore velocity in one dimension is calculated from the following equation:

$v=\frac{K}{n}\left[\frac{d h}{d x}\right]$

where:

$$
\begin{aligned}
\mathrm{v}= & \text { average linear pore velocity } \\
& (\text { ALPV) }(\mathrm{L} / \mathrm{T}) \\
\mathrm{K}= & \text { hydraulic conductivity }(\mathrm{L} / \mathrm{T}) \\
\mathrm{n}= & \text { effective porosity (dimensionless) } \\
\mathrm{h}= & \text { hydraulic head }(\mathrm{L}) \\
\mathrm{x}= & \text { distance between two points }(\mathrm{L})
\end{aligned}
$$

The $\mathrm{K}$ and $\mathrm{x}$ in the equation are inputs to the flow model. The values of $h$ are output of the model (a distribution interpolated from measured heads can be used in some circumstances). Where transmissivity, $\mathrm{T}$, is used in the flow model, $\mathrm{K}$ is calculated by dividing $\mathrm{T}$ by the model layer thickness. Effective porosity is a parameter of a transport model or a pathline/streamline model, not a flow model parameter. Average linear pore velocity is not computed in the flow model directly, but it can be computed from the flow model geometry, hydraulic conductivities, predicted heads, and estimates of effective porosity. For this reason, velocity matching is a separate step from direct calibration of the flow model, but it can be used to constrain flow model calibration results in an iterative process3.

The PATH3D code (Zheng 1991) has been obtained and tested. It is designed to calculate the velocities and paths of fictitious particles using MODFLOW or MODFLOWP input and output. It can be used to calculate velocities, streamlines (steady-state flow) or pathlines (transient flow), and travel times between the contaminant source locations and the furthest expected extent of selected contaminants. Simple, linear retardation can also be included so the average velocity on direction of sorbed contaminants can also be calculated. Pathline/ streamline codes such as PATH3D do not include the dispersion term of a true transport code; therefore, plume spreading relative to the average movement is not included. 


\section{METHOD FOR DEVELOPING A LOCAL-SCALE MODEL}

The results of the regional model can be used to develop a local scale flow model for input to a contaminant transport model. The modeler should select an intermediate-scale (10 to $20 \mathrm{mi}$ ) subarea of the regional model covering the local area and obtain the groundwater fluxes at the subarea model boundaries obtained from the regional model. The following procedure should be used to develop a subarea flow model:

1. Locate the contaminant sources.

2. Determine (from preliminary calculations or historical data) the likely furthest extent of contaminant migration in the aquifer.

\section{Locate the subarea boundaries}

b. Sufficiently distant from each other so that the hydraulic gradient calibration criteria for the regional model is satisfied (see Section 5.2.2)
c. Away from strong sources of aquifer recharge or discharge (such as the spreading areas).

4. Obtain groundwater fluxes from the regional model nodes that correspond to the subarea model boundaries.

5. Prepare a subarea flow model grid with node spacing that is consistent with the resolution needed at the local scale. Contaminant transport considerations as well as local scale flow features (e.g., ponds and pumping wells) determine the subarea flow model grid resolution.
6. Distribute the fluxes from the regional model along the boundary nodes of the subarea model. This step of the procedure requires interpolation because the number of nodes along the boundaries of the subarea model are larger than the number of corresponding regional model nodes. Whatever interpolation method is used, the total flow rate and flow direction through the subarea model should be the same as in the corresponding area of the regional model.

7. If fewer than four layers are used for the subarea model, obtain the fluxes through the bottom of the subarea model from the regional model.

8. Calibrate the subarea model using intermediate and local-scale flow features.

9. Calibrate the contaminant transport model with groundwater contaminant concentration data where possible. Iterate between the subarea flow model calibration and the contaminant transport calibration because the transport calibration provides estimates of local-scale average linear groundwater velocities. The flow model parameters can be adjusted to better match contaminant plumes.

10. Proceed with the local-scale contaminant transport model according to facility- specific WAG project plans.

A similar process was used for the groundwater modeling portion of the Department of Energy Spent Nuclear Fuel Management and INEL Environmental Restoration and Waste Management Programs Draft Environmental Impact Statement as reported in Arnett and Rohe (1993), except that hydraulic heads were interpolated from a smaller regional model at the subarea model boundaries. Establishing flux boundary conditions for the subarea model is superior 
because the flow rate and, therefore, the general velocity components, are likely to be better and more consistent with the regional patterns.

The following paragraphs provide an example of preparing a subarea flow model. Figure 9-1 shows the boundaries of an example subarea model located on the regional model grid together with selected INEL facilities. It is assumed that contaminant transport modeling is planned for the Test Reactor Area (WAG 2) and the Idaho Chemical Processing Plant (WAG 3). The Radioactive Waste Management Complex (WAG 7) is also included, but if it were the primary or sole focus of the planned contaminant transport model, the southwest boundary of the subarea flow model should be positioned further to the southwest, and the northeast boundary could be moved southwest. The subarea model is oriented in a different direction than the regional flow model so the subarea model can be oriented with the intermediate-scale flow direction (see Arnett and Springer 1993). The subarea model boundaries shown on Figure 9-1 are irregular to match the regional-scale model grid lines. In actual practice, the subarea model boundaries would be straight, forming a rectangle. The fluxes at the regional model nodes would be interpolated onto the subarea model boundary nodes to maintain flow rate in the subarea consistent with the flow rate in the regional model for the same area.

The subarea model extends from near well usgs-97 in the north to beyond well usgs-011 in the south and from near well usgs-005 on the east to near well usgs-022 on the west. The errors in predicted gradient with the regional model are presented in Table 5-7. The northwest corner of the subarea model is clipped because (a) that section was not needed for modeling flow near the Test Reactor Area/Idaho Chemical Processing Plant, (b) there are few control wells in the area, and (c) it is desirable to reduce the amplitude of temporal changes in the flow induced by the variable underflow rate from the Little Lost River valley. Note that the spreading areas are well within the subarea model boundary. The western boundary may need to be moved further west to decrease boundary effects in the subarea flow model. 


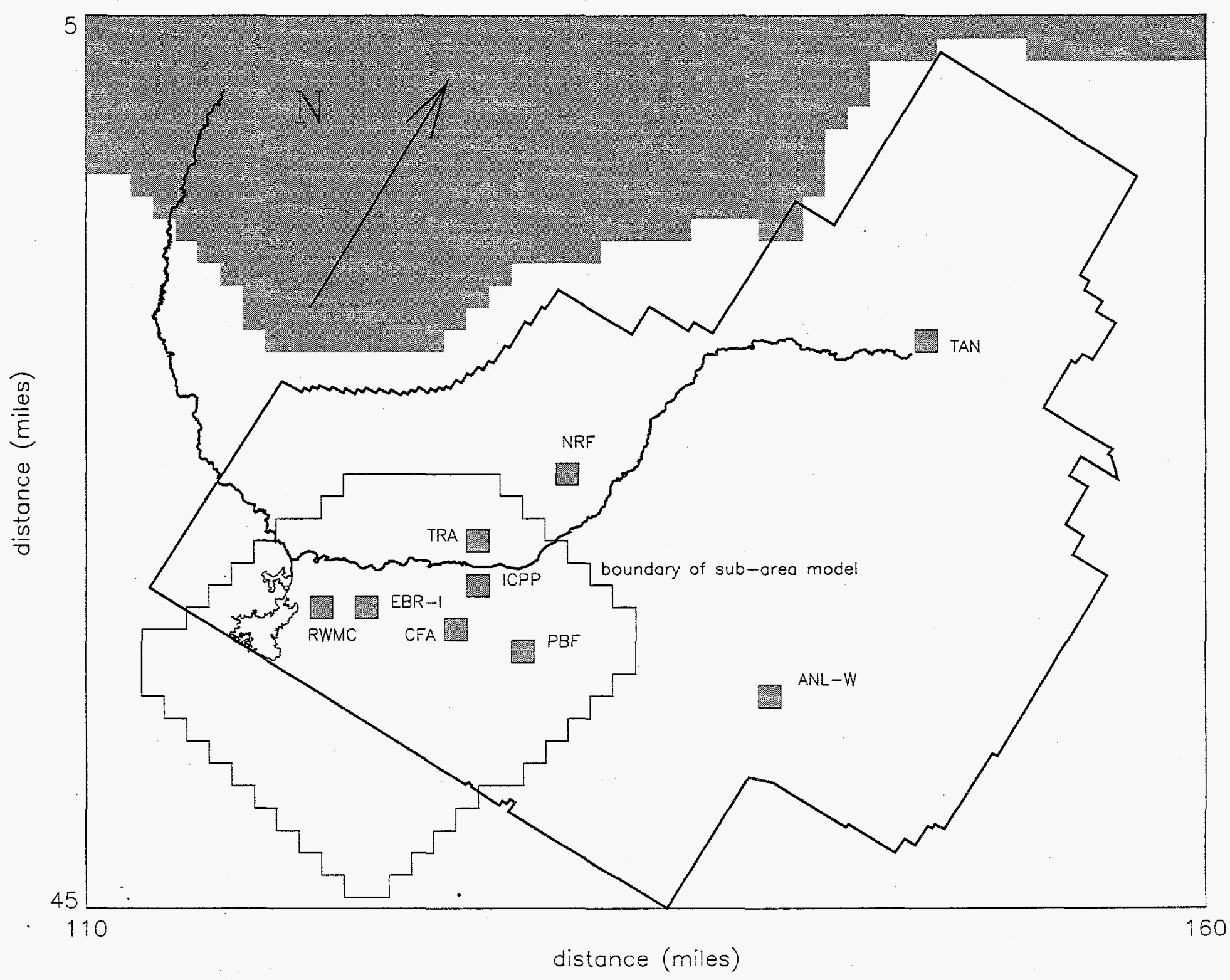

Figure 9-1. Hypothetical boundaries of an example subarea model located on the regional model grid. 


\section{SUMMARY}

The objective of developing the current model was to create a tool for defining the regional groundwater flow at the INEL. The model was developed to

- Support future transport modeling for WAG 10-04 by providing the regional groundwater flow information needed for the WAG 10-04 risk assessment

- Define the regional groundwater flow setting for modeling groundwater contaminant transport at the scale of the individual WAGs

- Provide a tool for improving the understanding of the groundwater flow system below the INEL

- Consolidate the existing regional groundwater modeling information into one usable model.

To accomplish the modeling objectives, six tasks were performed: (1) hydrogeologic data were compiled, (2) hydrologic evaluation tools were developed to analyze hydraulic head and aquifer temperature data, (3) graphical tools were developed to easily modify the model inputs and evaluate the model output, (4) existing models were integrated to consolidate the existing regional groundwater information, (5) the groundwater model had to be adequately calibrated, (6) sensitivity analysis was performed, (7) a WAG 10 data base was developed for all literature pertinent to WAG 10 groundwater modeling, (8) a source of information was established so modelers interested in modeling the regional groundwater flow below the INEL have ready. access to the codes developed, input files, and output files generated in this study, and (9) this report was written to document the flow model development and calibration and development of associated computational tools.

The groundwater flow conceptual model was developed by defining (1) the model area of interest (model domain), (2) the water gains and losses (water budget), and (3) the flow system (aquifer properties). It integrates a number of models previously developed and explained in detail in other reports. Therefore, this report summaries the essential components of the conceptual model and references other sources of information for additional detail.

The model domain, or model area of interest, is the boundary of the ESRP. The flow system used in the current model is comprised of four aquifer layers. The four-layer system is based on the model presented in Garabedian (1992) and represents the entire estimated thickness of the active aquifer.

Components of the groundwater budget incorporated in this model include (a) Snake River gains from and losses to the aquifer, (b) stream, canal, lake, and pond losses to the aquifer, (c) irrigation from surface water and groundwater, (d) precipitation, and

(e) underflow from tributary drainage basins. A 1980 water budget is used for the pseudo steady-state model. The transient model focuses on the transient impact of the Big Lost River, Little Lost River, and Birch Creek from 1980 to 1990.

The graphical and hydrologic evaluation tools and literature database are used for the groundwater system evaluation, model calibration, and development of the report. The particle tracking code PATH3D was tested for use for this study but not used with the current model.

The numerical model integrates the Garabedian, Spinazola, EIS, and WAG 10 models. The hydraulic conductivity $(\mathrm{K})$ values 
in the model are defined using a zonation approach, where the domain is divided into zones of equal $\mathrm{K}$. The zones were initially defined based on Garabedian's layer $1 \mathrm{~K}$ zones. The $K$ values were assumed to be equal to the average values estimated from Garabedian's transmissivity values. The average of Spinazola's layers 1 and $2 \mathrm{~K}$ zones were used in the northeastern portion of the domain. In the vicinity of the INEL, new zones were initially defined to simulate the hydraulic head variations across the INEL Site based on the EIS model $\mathrm{K}$ zones and the FY 93 WAG $10 \mathrm{~K}$ zones. The INEL zones were modified during the calibration process.

The following five types of calibration targets were used for this modeling study:

(1) hydraulic head, (2) hydraulic head gradient, (3) water budget, (4) parameter value range, and (5) parameter reliability. The hydraulic head gradient target is included because the current model is a tool for defining the regional hydraulic setting for the local-scale groundwater transport modeling performed for WAGs 1 through 9. Therefore, the flow velocity is the primary parameter of importance and the gradient is needed to calculate the flow velocity.

The pseudo steady-state hydraulic head calibration targets were satisfied on 13 of the 21 key wells. Hydraulic head residuals for the other 8 key wells ranged from just over the target to a factor of three times the target. The transient calibration targets (average residual from 1980 to 1990) were satisfied for 11 of the 21 key wells. The hydraulic gradient targets were satisfied at the intermediate scale but not at the local scale. Therefore, the submodel scale necessary for a site-specific WAG model must be significantly larger than the actual area of the WAG. The submodel scale necessarily depends both on the accuracy needed for the site-specific WAG flow modeling and the accuracy of the current (regional scale) model. A WAG that requires a very accurate water velocity to predict contaminant and transport will have to use a larger submodel than a WAG that requires less accuracy.

The overall water budget is satisfactory, but the simulated gains and losses along the Snake River are not well distributed.

Calibration was not performed outside the vicinity of the INEL; therefore, no effort was made to improve the distribution of the gains and losses.

The calibrated model meets the parameter range calibration target for all the $\mathrm{K}$ zones and the parameter reliability target for almost all of the $\mathrm{K}$ zones. The parameter reliability target is a coefficient of variation of less than 1 for each of the $\mathrm{K}$ zones used in the calibration. The coefficient of variation is greater than 1 in the northern portion of the INEL where the head distribution is complex (which implies the need for many small $\mathrm{K}$ zones), and there are few observation wells to constrain the calibration results.

The purpose of the sensitivity analysis was to quantify the uncertainty in the model solutions to the most significant and uncertain inputs to the model. The sensitivity of the model solutions to each parameter is a function of the magnitude of the sensitivity coefficients, the areal distribution of the sensitivity coefficients, and the possible range over which the parameter can vary. The model solutions are most sensitive to $\mathrm{K}$ because the possible range of $\mathrm{K}$ values is extremely large, the sensitivity coefficients are fairly large, and the areal distribution of the sensitivity coefficients is not uniform. Although the model is not as sensitive to the underflow as it is to $K$, some wells within the INEL are sensitive to the underflows from the Big Lost River, Little Lost River, and Birch Creek drainage basins. The underflows are a transient parameter; therefore, they had to be 
incorporated into the transient model. The sensitivity coefficients for the other drainage basins are significantly smaller than those for the Big Lost River, Little Lost River, and Birch Creek drainage basins; therefore, the model is not sensitive to those parameters. The model is not sensitive to the overall recharge, pumping, Snake River conductance, or vertical hydraulic conductivity because the areal distribution of the sensitivity coefficients is fairly uniform and the possible range over which the parameter values can vary is small in comparison to $\mathrm{K}$.

The assumptions made for this modeling study resulted in a number of modeling limitations.

1. The large scale of the model limits the accuracy of the hydraulic gradient and flow directions for defining the regional setting of the local scale. Therefore, a submodel must be chosen large enough so that the errors in the hydraulic gradient and flow direction defined by the regional model meet the requirements of the submodel.

2. The model is only calibrated for the hydraulic head in the upper layer of the model. This limits the usefulness of the hydraulic heads simulated for the other layers because the accuracy of these predictions has not been evaluated.

3. The model calibration is focused on the INEL and in particular in the immediate vicinity of the WAGs. This limits the usefulness of the model simulation results outside the area of the INEL. In addition, the calibration performed in the area of the INEL influences the hydraulic head values in the rest of the model domain and no calibration was done to recalibrate for those areas.
4. The transient flow model developed is very simplified. It incorporates quarterly transient underflow from the Big Lost River, Little Lost River, and Birch Creek drainage basins but defines all other water budget components as steady state. It defines one homogeneous storage coefficient to the upper layer and another to the lower three layers. Therefore, if the sensitivity to other water budget components or to the spatial variability of storage coefficient is needed, modifications to the transient model input files will be needed.

5. The calibrated hydraulic conductivity values are applicable for the model designed but not necessarily appropriate if the regional model is modified or for use on a smaller scale model. Therefore, if the water budget or the calibration objectives change, then the model would have to be recalibrated.

The current model is appropriate for defining the regional flow setting for flow submodels as well as hypothesis testing to better understand the regional groundwater flow in the area of the INEL. The scale of the submodels must be chosen based on accuracy required for the study. There is no fixed required minimum submodel size.

A common misconception is that the input files for a parameter estimation code such as MODFLOWP must only be defined and then the code will generate a calibrated model and the study is complete. In reality, a groundwater numerical model is a very complicated mathematical description of reality, and many parameters interact to provide a final solution. Not all of the information necessary to accurately set up the input file is available. Therefore, the modeler must test different input information (such as hydraulic parameter zones) to create a model that meets the objectives of the modeling 
study. MODFLOWP is a powerful tool used to combine trail and error with automatic parameter estimation.

The results of this study, including computer codes, input and output files, and samples of the output from the hydrologic evaluation and graphical tools, are archived and available through the Hydrological Data Repository maintained by WAG 10 . 


\section{REFERENCES}

Ackerman, D. J., 1991, Transmissivity of the Snake River Plain Aquifer at the Idaho National Engineering Laboratory, Idaho, USGS Water-Resources Investigations Report 91-4058.

Arnett, R. C., 1993a, Analysis of Iodine-129 Trends in the Aquifer Beneath the Idaho National Engineering Laboratory, letter report, EG\&G Idaho, Inc.

Arnett, R. C., 1993b, Contaminant Plume Chemistry and Other Data Needed for WAG 10 Groundwater Contaminant Transport Modeling, Engineering Design File ER-WAG10-0005, EG\&G Idaho, Inc.

Arnett, R. C. and J. M. Brower, 1993, Groundwater Flow Model Data and Bounding Assumptions for Model Calibration, Engineering Design File ER\&WM-0001-93, EG\&G Idaho, Inc.

Arnett, R. C. and J. M. McCarthy, 1993, Hydrologic/Hydraulic Data Needed for WAG 10 Groundwater Flow Modeling of the Snake River Plain Aquifer (OU 10-04), Engineering Design File EGGERWM-EDF-0002-93, EG\&G Idaho, Inc.

Arnett, R. C. and R. K. Springer, 1993, Groundwater Flow Model Calibration for a Portion of the Snake River Plain Aquifer Near the Idaho National Engineering Laboratory, Engineering Data File ER\&WM-EDF-0024-93, EG\&G Idaho, Inc.

Arnett, R. C., R. C. Martineau, and M. J. Lehto, 1990, Preliminary Numerical Model of Radionuclide Transport in the Snake River Plain Aquifer Near the Idaho National Engineering Laboratory, EGG-WM-8820.

Arnett, R. C., J. M. McCarthy, G. T. Norrell, A. L. Schaefer-Perini, and T. R. Wood, 1993, Basis for Initial Code Selection For WAG 10 Groundwater and Contaminant Transport Modeling at the Idaho National Engineering Laboratory, EGG-ERD-10532.

DOE (U.S. Department of Energy), 1994, Department of Energy Spent Nuclear Fuel Management of INEL Environmental Restoration and Waste Management Program Draft Environmental Impact Statement, DOE-EIS-0203D.

Freeze, R. A. and J. A. Cherry, 1979, Groundwater, Englewood Cliffs, NJ: Prentice-Hall, Inc.

Garabedian, S. P., 1986, Application of a Parameter-Estimation Technique to Modeling the Regional Aquifer Underlying the Eastern Snake River Plain, Idaho, U.S. Geological Survey WaterSupply Paper 2278.

Garabedian, S. P., 1992, Hydrology and Digital Simulation of the Regional Aquifer System, Eastern Snake River Plain, Idaho, USGS Professional Paper 1408-F.

Goode, D. J. and L. F. Konikow, 1990, "Reevaluation of Large-Scale Dispersivities for a Waste Chloride Plume: Effects of Transient Flow," International Conference on Calibration and Reliability in Groundwater Modeling, International Association of Hydrological Sciences, September 6-9, 1990, The Hague, The Netherlands. 
Hill, M. C., 1992, A Computer Program (MODFLOWP) for Estimating Parameters of a Transient, Three-Dimensional, Ground-Water Flow Model Using Nonlinear Regression, U.S. Geological Survey Open File Report 91-484.

Johnson, G. S., C. E. Brockway, and S. P. Luttrell, 1984, Application of a Numerical Ground-Water Flow Model to the Mud Lake Area in Southeastern Idaho, Moscow, University of Idaho, Idaho Water Resources Research Institute Technical Completion Report.

Kjelstrom, L. C., 1986, Flow Characteristics of the Snake River and Water Budget for the Snake River Plain, Idaho and Eastern Oregon: U.S. Geological Survey Hydrologic Investigations Atlas HA-680, scale 1:1,000,000, 2 sheets.

Kjelstrom, L. C., 1990, Streamflow Gains and Losses in the Snake River and Ground-Water Budget for the Snake River Plain, Idaho and Eastern Oregon, U.S. Geological Survey, Open-File Report 90-172.

Lewis, B. D. and F. J. Goldstein, 1982, Evaluation of a Predictive Ground-Water Solute-Transport Model at the Idaho National Engineering Laboratory, Idaho, WRI/82-25, IDO-22062, U.S. Geological Survey.

McCarthy, J. M., 1993a, Review of the Current and Planned Modeling Efforts for WAGs 1-9, letter report, EG\&G Idaho, Inc.

McCarthy, J. M., 1993b, Testing of the WAG 10 Groundwater Flow and Transport Codes, Engineering Design File ER\&WM-EDF-0004-93, EG\&G Idaho, Inc.

McCarthy, J. M., 1993c, Preparation of Preliminary WAG 10 Simulation Models, Engineering Design File ER-WAG10-30, EG\&G Idaho, Inc.

McCarthy, J. M. and R. C. Arnett, 1993, Information Transfer and Coordination of Groundwater Flow and Transport Modeling Between WAG 10 and WAGs 1 Through 9, letter report, EG\&G Idaho, Inc.

McCarthy, J. M. and M. J. Rohe, 1994, Critical Evaluation of the Use of Available Data for Regional Model Calibration, Engineering Design File ER-WAG10-37, EG\&G Idaho, Inc.

McCarthy, J. M. and R. M. Neupauer, 1993, Preliminary Groundwater Flow Model Calibration, Engineering Design File ER-WAG10-33, EG\&G Idaho, Inc.

McCarthy, J. M., R. C. Arnett, R. M. Neupauer, and M. J. Rohe, 1994, Summary of WAG 10 Groundwater Modeling Results for FY-93, Draft, EGG-ER-11132.

McDonald, M. G. and A. W. Harbaugh, 1988, "A Modular Three-Dimensional Finite-Difference Ground-Water Flow Model," U.S. Geological Survey Techniques of Water-Resources Investigations Book 6, Chapter A1, U.S. Geological Survey.

Norrell, G. T. et al., 1993, Geochronologic Tracing of Contaminant Transport in Radioactive Groundwater Plumes, letter report, EG\&G Idaho, Inc. 
Robertson, J. B., 1974, Digital Modeling of Radionuclide and Chemical Waste Transport in the Snake River Plain Aquifer at the National Reactor Testing Station, Idaho, U.S. Geological Survey, ID0-22054.

Robertson, J. B., 1977, Numerical Modeling of Subsurface Radioactive Solute Transport From WasteSeepage Ponds at the Idaho National Engineering Laboratory, USGS Open File Report 76-717, IDO-22057.

Rood, A. S., R. C. Arnett, and J. T. Barraclough, 1989, Contaminant Transport in the Snake River Plain Aquifer: Phase I, Part 1: Simple Analytical Model of Individual Plumes, EGG-ER-8623.

Schafer-Perini, A. L., 1993, TAN Groundwater RI/FS Contaminant Fate and Transport Modeling Results, Engineering Design File ER-WAG1-21.

Spinazola, J. M., 1994a, Geohydrology and Simulation of Flow and Water Levels in the Aquifer System in the Mud Lake Area of the Eastern Snake River Plain, Eastern Idaho, U.S. Geological Survey Water Resources Investigations Report 93-4227.

Spinazola, J. M., 1994b, Simulation of Changes in Water Levels and Ground-water Flow in Response to Water-use Alternatives in the Mud Lake Area, Eastern Snake River Plain, Eastern Idaho, U.S. Geological Survey Water Resources Investigations Report 93-4228.

Visual Numerics, 1993, PV-Wave Advantage, PV-WAVE Command Language, Version 4.2, Visual Numerics, Inc., Houston, Texas.

Whitehead, R. L., Geohydrologic Framework of the Snake River Plain, Idaho and Eastern Oregon: U.S. Geological Survey Hydrologic Investigations Atlas HA-681, scale $1: 1,000,000,3$ sheets.

Wylie, A. H., 1993, Gyroscopic Directional Survey of Central Facilities Area Groundwater Wells, Engineering Design File ER-WAG4-31, EG\&G Idaho, Inc.

Zheng, C., 1992, MT3D - A Modular Three-Dimensional Transport Model (Version 1.5), Documentation and User's Guide, second revision, Bethesda, MD: S. S. Papadopulos \& Associates, Inc. 
Appendix A

Steady-State Parameter Estimation Package Input File 

September 15, 1994

Steady state parameter estimation run

$\begin{array}{lllllll}75 & 232 & 0 & 4 & 3 & 4 & 3\end{array}$

$\begin{array}{lllllll}-4 & 1 & 2 & & & & \\ 48 & 0 & 0 & 0 & 0 & 0 & 0\end{array}$

$\begin{array}{llll}1 & -1 & 1 & 1\end{array}$

$60 \quad 80 \quad 0$

T

$\begin{array}{lll}0 & 1 & 0\end{array}$

1. 11151

1. 21151

$\begin{array}{llll}.67 & 3 & 1 & 51\end{array}$

T $\quad 0 \begin{array}{rrrr}33 & 4 & 1 & 51\end{array}$

$\begin{array}{llll}1 & 1 & 1 & 53\end{array}$

1. 21153

$.67 \quad 3 \quad 1 \quad 53$

$\begin{array}{llll}.33 & 4 & 1 & 53\end{array}$

T $\begin{array}{lllll}0 & 1 & 2 & 3 & 4\end{array}$

1. 1155

1. 21255

$\begin{array}{llll}.67 & 3 & 1 & 55\end{array}$

$\begin{array}{llll}.33 & 4 & 1 & 55\end{array}$

T $\quad 0 \quad \begin{array}{rrrr}1 & 2 & 3 & 4\end{array}$

1. 111056

1. 2.156

$\begin{array}{llll}.67 & 3 & 1 & 56\end{array}$

$\begin{array}{llll}.33 & 4 & 1 & 56\end{array}$

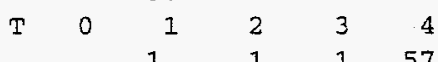

$\begin{array}{llll}1 . & 1 & 1 & 57 \\ 1 . & 2 & 1 & 57\end{array}$

$\begin{array}{llll}.67 & 3 & 1 & 57\end{array}$

$\begin{array}{llll}.33 & 4 & 1 & 57\end{array}$

T $\begin{array}{rrrrr}0 & 1 & 2 & 3 & 4\end{array}$

1. $1 \quad 1 \quad 54$

1. 21154

$\begin{array}{llll}.67 & 3 & 1 & 54\end{array}$

$.33 \quad 4 \quad 1 \quad 54$

$\begin{array}{llllll}\mathrm{T} & 0 & 1 & 2 & 3 & 4\end{array}$

1. 1160

1. $2 \quad 160$

$\begin{array}{llll}.67 & 3 & 1 & 50\end{array}$

$.33 \cdot 4 \quad 1 \quad 50$

$\begin{array}{rrrrrr}\mathrm{T} & 0 & 1 & 2 & 3 & 4\end{array}$

1. 11158

1. 2158

$\begin{array}{llll}.67 & 3 & 1 & 58\end{array}$

$\begin{array}{llll}.33 & 4 & 1 & 58\end{array}$

T $\begin{array}{rrrrr}0 & 1 & 2 & 3 & 4\end{array}$

1. 11159

1. 210159

$.67 \quad 3 \quad 159$

$\begin{array}{rrrrr} & .33 & 4 & 1 & 59 \\ 0 & 1 & 2 & 3 & 4\end{array}$

1. 1112

$\begin{array}{llll}1.00 & 2 & 1 & 12\end{array}$

$\begin{array}{llll}0.67 & 3 & 1 & 12\end{array}$

$\begin{array}{llll}0.33 & 4 & 1 & 12\end{array}$

$\begin{array}{llllll}\mathrm{T} & 0 & 1 & 2 & 3 & 4\end{array}$

1. 11162

1. $2 \quad 1 \quad 62$

$\begin{array}{llll}.67 & 3 & 1 & 62\end{array}$

$.334 \quad 1 \quad 62$
LINE 1

LINE 2

LINE 3 /np,nsm, nsn, nllil, lzil,nmm,nzm

LINE 4 /iprnp, icheck, numr

LINE 5 /nh, mobs, maxm, nq, nqc, nqt, mpr

IINE 6 /ipar, isn, iscals, nopt,

LINE 7 /iuhead, ioub, iubd, iunhea

LINE 8 /nrwd, nzer, npng

\#1 DATA SET 2B

\#2 DATA SET 2B

\#3 DATA SET 2B

\#4 DATA SET 2B

\#5 DATA SET 2B

\#6 DATA SET 2B

\#7 DATA SET $2 \mathrm{~B}$

\#8 DATA SET 2B

\#9 DATA SET $2 B$

\#10 DATA SET 2B

\#11 DATA SET 2B 


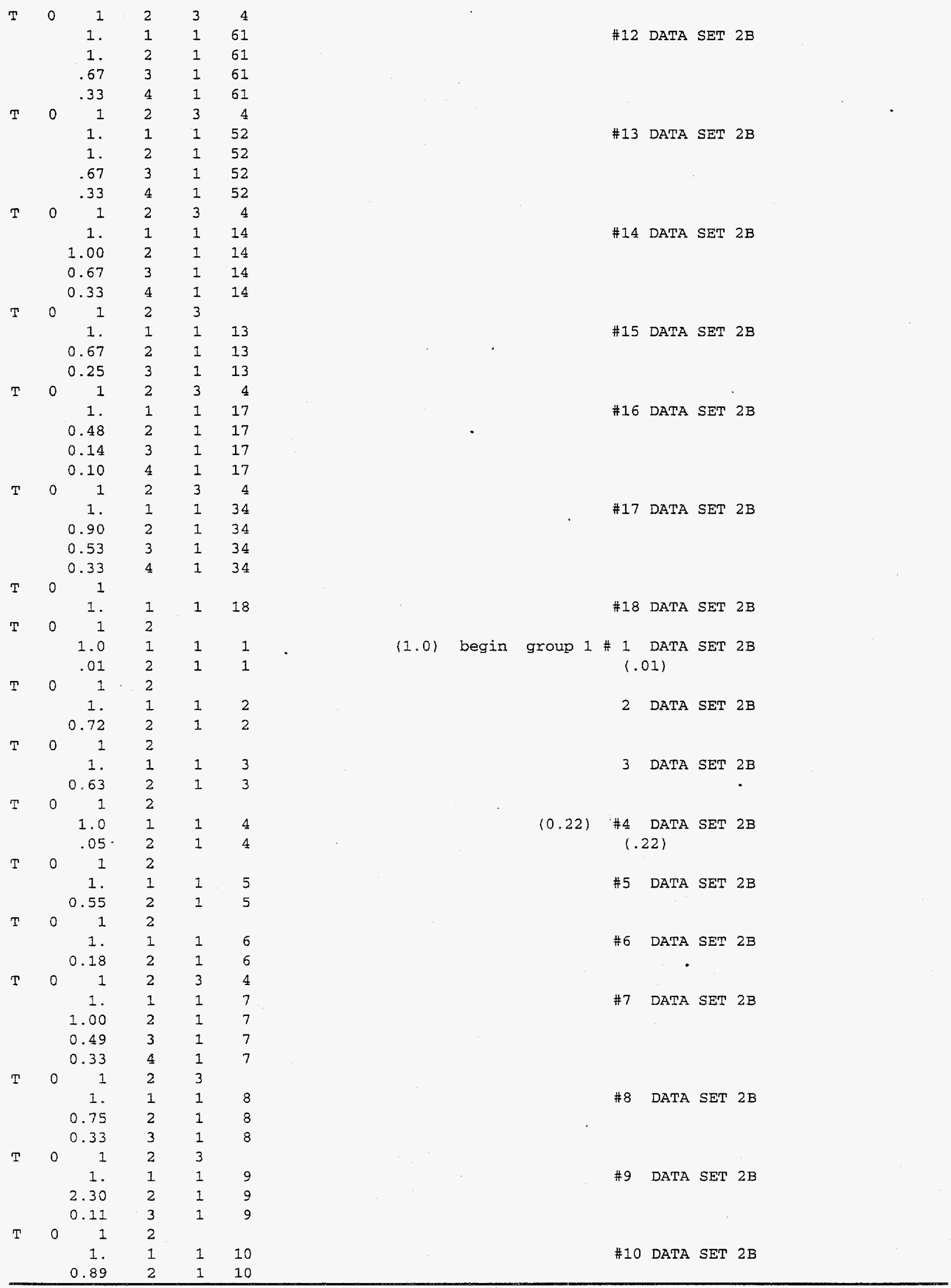




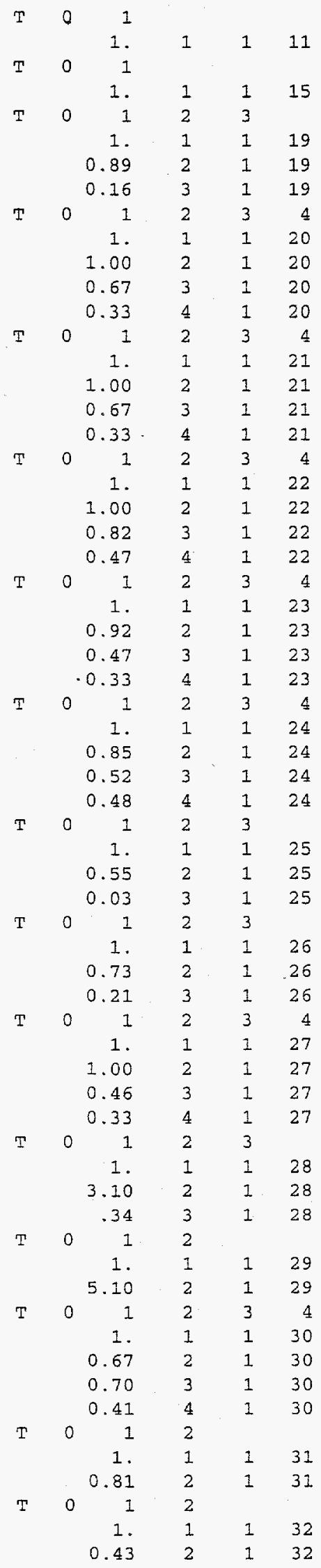

\#11 DATA SET 2B

\#12 DATA SET 2B

\#13 DATA SET 2B

\#14 DATA SET 2B

\#15 DATA SET 2B

\#16 DATA SET 2B

\#17 DATA SET 2B

\#18 DATA SET 2B

\#19 DATA SET 2B

\#20 DATA SET 2B

\#21 DATA SET 2B

\#22 DATA SET 2B

\#23 DATA SET 2B

\#24 DATA SET 2B

\#25 DATA SET 2B

\#26 DATA SET 2B 


\begin{tabular}{|c|c|c|c|c|c|}
\hline \multirow[t]{5}{*}{$T$} & 0 & 1 & 2 & 3 & 4 \\
\hline & & 1. & 1 & 1 & 33 \\
\hline & & 0.95 & 2 & 1 & 33 \\
\hline & & 0.52 & 3 & 1 & 33 \\
\hline & & 0.33 & 4 & 1 & 33 \\
\hline \multirow[t]{2}{*}{$\mathbf{T}$} & 0 & 1 & & & \\
\hline & & 1. & 1 & 1 & 16 \\
\hline \multirow[t]{2}{*}{$\mathrm{T}$} & 0 & 1 & & & \\
\hline & & 1. & 1 & 1 & 35 \\
\hline \multirow[t]{2}{*}{$\mathrm{T}$} & 0 & 1 & & & \\
\hline & & 1. & 1 & 1 & 36 \\
\hline \multirow[t]{2}{*}{$\mathrm{T}$} & 0 & 1 & & & \\
\hline & & 1. & 1 & 1 & 37 \\
\hline \multirow[t]{5}{*}{$T$} & 0 & 1 & 2 & 3 & 4 \\
\hline & & 1. & 1 & 1 & 38 \\
\hline & & 1.00 & 2 & 1 & 38 \\
\hline & & 0.55 & 3 & 1 & 38 \\
\hline & & 0.33 & 4 & 1 & 38 \\
\hline \multirow[t]{5}{*}{$\mathrm{T}$} & 0 & 1 & 2 & 3 & 4 \\
\hline & & 1. & 1 & 1 & 39 \\
\hline & & 1.00 & 2 & 1 & 39 \\
\hline & & 0.67 & 3 & 1 & 39 \\
\hline & & .33 & 4 & 1 & 39 \\
\hline \multirow[t]{2}{*}{$\mathrm{T}$} & 0 & 1 & & & \\
\hline & & 1. & 1 & 1 & 140 \\
\hline \multirow[t]{2}{*}{$\mathrm{T}$} & 0 & 1 & & & \\
\hline & & 1. & 1 & 1 & 1141 \\
\hline \multirow[t]{2}{*}{$T$} & 0 & 1 & & & \\
\hline & & 1. & 1 & 1 & 1142 \\
\hline \multirow[t]{4}{*}{$\mathrm{T}$} & 0 & 1 & 2 & 3 & \\
\hline & & 1. & 1 & 1 & 71 \\
\hline & & 0.95 & 2 & 1 & 71 \\
\hline & & .67 & 3 & 1 & 71 \\
\hline \multirow[t]{5}{*}{$T$} & 0 & 1 & 2 & 3 & 4 \\
\hline & & 1. & $I$ & 1 & 72 \\
\hline & & 1.0 & 2 & 1 & 72 \\
\hline & & .67 & 3 & 1 & 72 \\
\hline & & .33 & 4 & 1 & 72 \\
\hline \multirow[t]{4}{*}{$T$} & 0 & 1 & 2 & 3 & \\
\hline & & 1. & 1 & 1 & 73 \\
\hline & & .97 & 2 & 1 & 73 \\
\hline & & .67 & 3 & 1 & 73 \\
\hline \multirow[t]{5}{*}{$T$} & 0 & 1 & 2 & 3 & 4 \\
\hline & & 1. & 1 & 1 & 74 \\
\hline & & 1. & 2 & 1 & 74 \\
\hline & & .67 & 3 & 1 & 74 \\
\hline & & .33 & 4 & 1 & 74 \\
\hline \multirow[t]{5}{*}{$T$} & 0 & 1 & 2 & 3 & 4 \\
\hline & & 1 & 1 & 1 & 75 \\
\hline & & .72 & 2 & 1 & 75 \\
\hline & & 0.87 & 3 & 1 & 75 \\
\hline & & 0.09 & 4 & 1 & 75 \\
\hline $\mathrm{T}$ & 0 & 1 & 2 & 3 & 4 \\
\hline & & 1. & 1 & 1 & 76 \\
\hline & & 29.1 & 2 & 1 & 76 \\
\hline & & .67 & 3 & 1 & 76 \\
\hline & & .33 & 4 & 1 & 76 \\
\hline $\mathrm{T}$ & 0 & 1 & 2 & 3 & 4 \\
\hline & & 1 & 1 & 1 & 77 \\
\hline & & 0.87 & 2 & 1 & 77 \\
\hline & & .52 & 3 & 1 & 77 \\
\hline & & 0.09 & 4 & 1 & 77 \\
\hline
\end{tabular}

$\# 27$ DATA SET 2B

\#28 DATA SET 2 B \#29 DATA SET 2B \#30 DATA SET 2B \#31 DATA SET 2B \#32 DATA SET 2 B \#33 DATA SET 2B (dumny) \#34 DATA SET 2B (dummy) \#35 DATA SET 2B end group 1 (dummy) \#36 DATA SET 2B begin group $3 \# 1$ DATA SET 2B (7.30) 2 DATA SET 2B (6.5) (3.1) 3 DATA SET 2B

4 DATA SET 2B $(6.4)$ (20.) (39.)

5 DATA SET 2B

6 DATA SET 2B (68.) (53.)

7 DATA SET 2B 


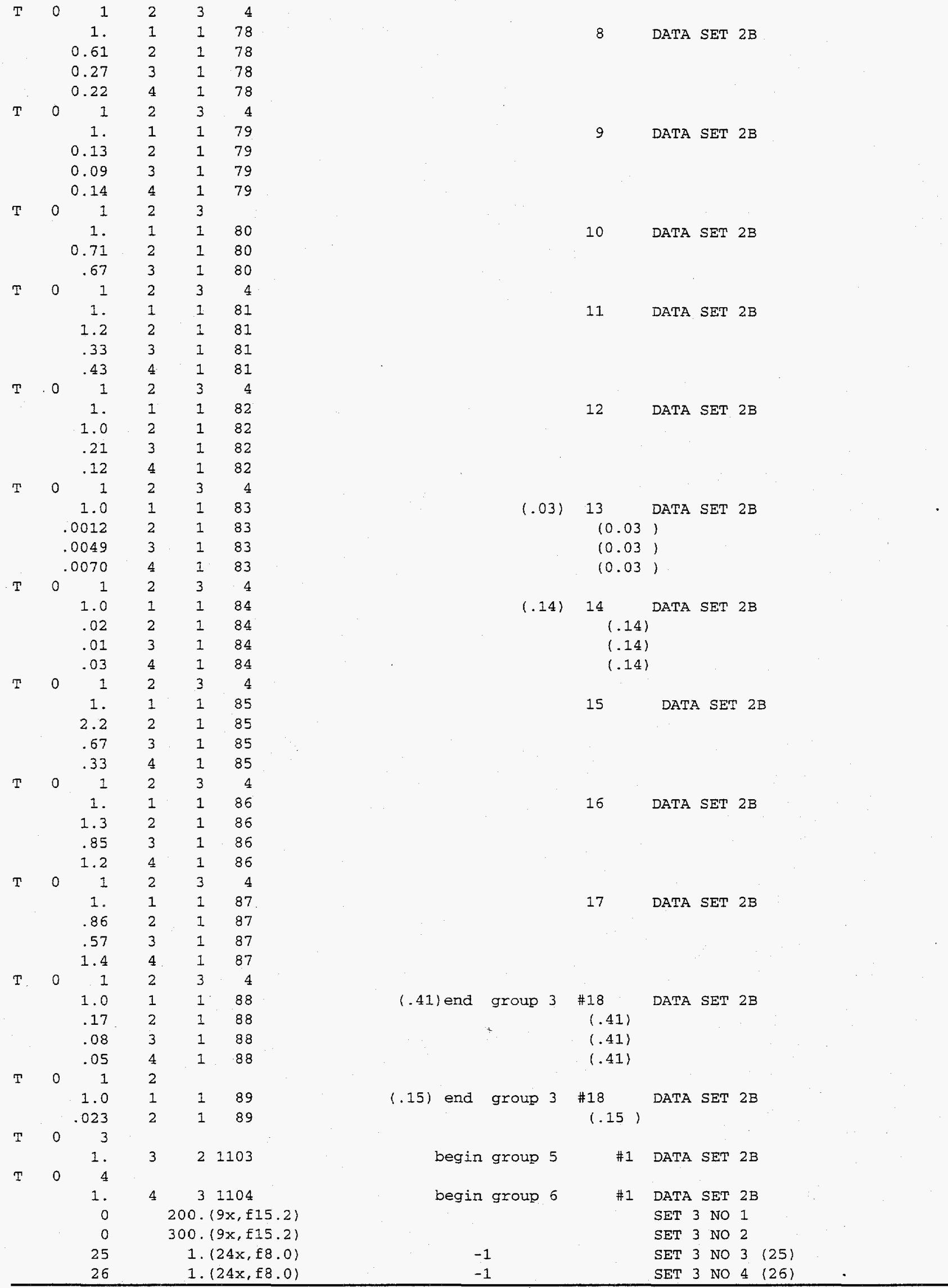




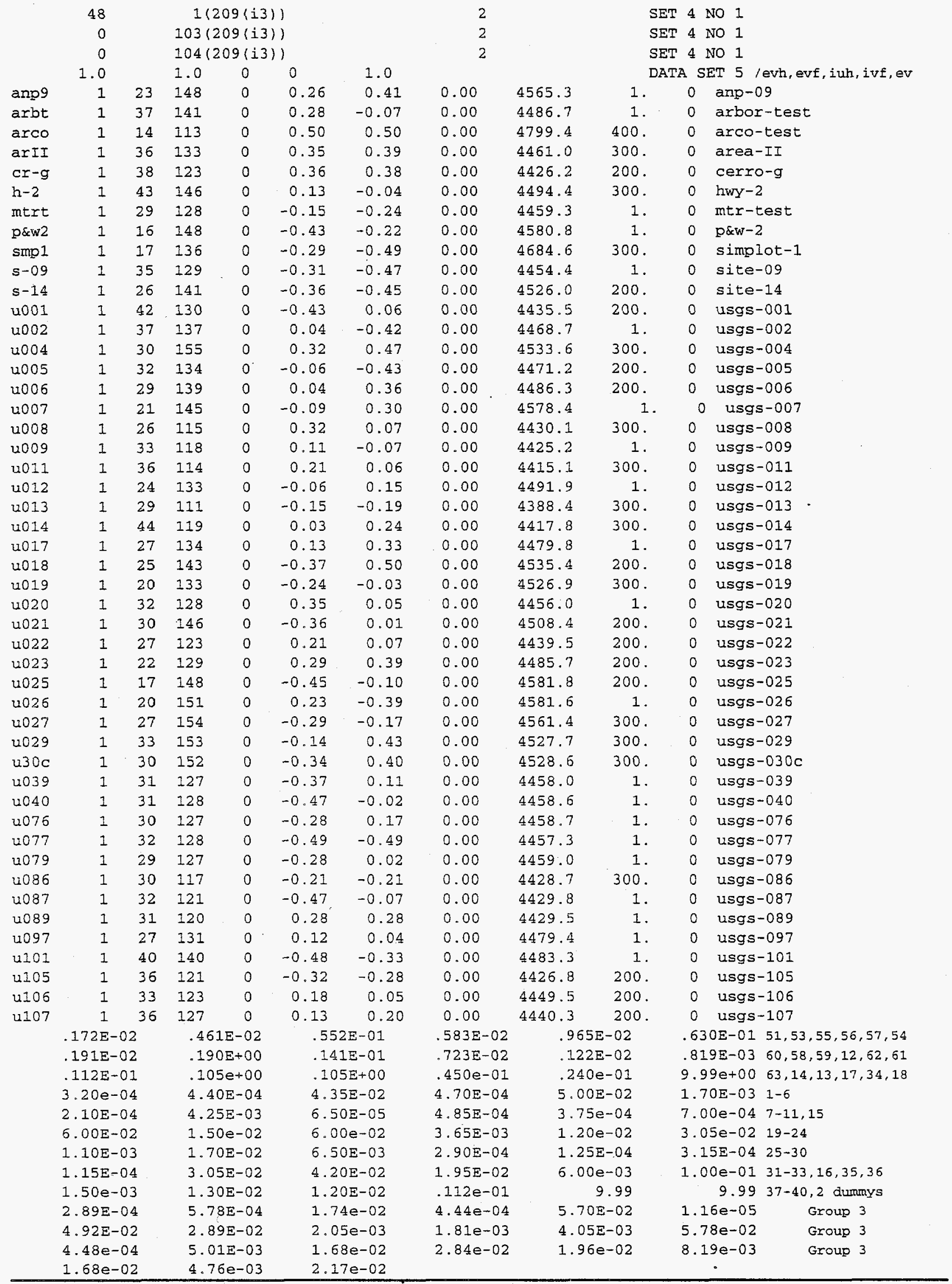




\begin{tabular}{|c|c|c|c|c|}
\hline 2 & 2 & 2 & 2 & 2 \\
\hline 2 & 2 & 2 & 2 & 7 \\
\hline-9 & -1 & -1 & -1 & -1 \\
\hline-1 & 1 & 1 & 1 & 1 \\
\hline 1 & 1 & 1 & 1 & 1 \\
\hline 1 & 1 & 1 & 1 & 1 \\
\hline 1 & 1 & 1 & 1 & 1 \\
\hline 1 & 1 & 1 & 1 & 1 \\
\hline 1 & 1 & 1 & 1 & 1 \\
\hline 3 & 3 & 3 & 3 & 3 \\
\hline 3 & 3 & 3 & 3 & 3 \\
\hline 3 & 3 & 3 & 3 & 3 \\
\hline 3 & 4 & 5 & & \\
\hline 0.0 & 0.0 & 0.0 & 0.0 & 0.0 \\
\hline 0.0 & 0.0 & 0.0 & 0.0 & 0.0 \\
\hline 0.0 & 0.0 & 0.0 & 0.0 & 0.0 \\
\hline 0.0 & 0.0 & 0.0 & 0.0 & 0.0 \\
\hline 0.0 & 0.0 & 0.0 & 0.0 & 0.0 \\
\hline 0.0 & 0.0 & 0.0 & 0.0 & 0.0 \\
\hline 0.0 & 0.0 & 0.0 & 0.0 & 0.0 \\
\hline 0.0 & 0.0 & 0.0 & 0.0 & 0.0 \\
\hline 0.0 & 0.0 & 0.0 & 0.0 & 0.0 \\
\hline 0.0 & 0.0 & 0.0 & 0.0 & 0.0 \\
\hline 0.0 & 0.0 & 0.0 & 0.0 & 0.0 \\
\hline 0.0 & 0.0 & 0.0 & 0.0 & 0.0 \\
\hline 0.0 & 0.0 & 0.0 & & \\
\hline
\end{tabular}

Data set 9

1 $0.990 .080 .10 \quad 20$
2.0 

Appendix B

Comparison of the Simulated Versus the Measured Hydraulic Heads for the Transient Model 

Table B-1. Transient model head comparisons.

\begin{tabular}{|c|c|c|c|c|c|c|}
\hline Well & $\begin{array}{l}\text { Measured } \\
\text { date }\end{array}$ & $\begin{array}{l}\text { Simulated } \\
\text { day }\end{array}$ & $\begin{array}{l}\text { Simulated } \\
\text { year }\end{array}$ & $\begin{array}{l}\text { Measured } \\
\text { head }\end{array}$ & $\begin{array}{l}\text { Model } \\
\text { head }\end{array}$ & Residual \\
\hline anp-07 & $03 / 15 / 80$ & 75 & 0.205 & 4582.80 & 4579.44 & 3.36 \\
\hline anp-07 & $07 / 07 / 81$ & 554 & 1.517 & 4582.19 & 4579.09 & 3.10 \\
\hline anp-07 & $07 / 13 / 82$ & 925 & 2.533 & 4581.27 & 4578.74 & 2.53 \\
\hline anp-07 & $07 / 18 / 83$ & 1295 & 3.546 & 4581.40 & 4578.71 & 2.69 \\
\hline anp-07 & $07 / 19 / 84$ & 1662 & 4.550 & 4583.60 & 4579.23 & 4.37 \\
\hline anp-07 & $07 / 17 / 85$ & 2025 & 5.544 & 4585.60 & 4580.03 & 5.57 \\
\hline anp-07 & $08 / 07 / 87$ & 2776 & 7.600 & 4587.80 & 4581.62 & 6.18 \\
\hline anp-07 & $05 / 31 / 88$ & 3074 & 8.416 & 4589.90 & 4581.90 & 8.00 \\
\hline anp-07 & $05 / 19 / 89$ & 3427 & 9.383 & 4588.50 & 4581.77 & 6.74 \\
\hline anp-07 & $05 / 16 / 90$ & 3789 & 10.374 & 4587.40 & 4581.47 & 5.94 \\
\hline anp-09 & $03 / 13 / 80$ & 73 & 0.200 & 4565.30 & 4566.20 & -0.90 \\
\hline anp-09 & $03 / 27 / 81$ & 452 & 1.238 & 4565.00 & 4565.91 & -0.91 \\
\hline anp-09 & $03 / 29 / 82$ & 819 & 2.242 & 4564.52 & 4565.60 & -1.08 \\
\hline anp-09 & $03 / 14 / 83$ & 1169 & 3.201 & 4564.50 & 4565.45 & -0.95 \\
\hline anp-09 & $03 / 28 / 84$ & 1549 & 4.241 & 4566.30 & 4565.83 & 0.47 \\
\hline anp-09 & $04 / 25 / 85$ & 1942 & 5.317 & 4568.80 & 4566.52 & 2.28 \\
\hline anp-09 & $03 / 25 / 86$ & 2276 & 6.231 & 4570.20 & 4567.18 & 3.02 \\
\hline anp-09 & $05 / 01 / 87$ & 2678 & 7.332 & 4571.70 & 4567.85 & 3.85 \\
\hline arbor-test & $03 / 18 / 80$ & 78 & 0.214 & 4486.70 & 4483.87 & 2.83 \\
\hline arbor-test & $03 / 27 / 81$ & 452 & 1.238 & 4486.20 & 4483.54 & 2.66 \\
\hline arbor-test & $03 / 25 / 82$ & 815 & 2.231 & 4485.93 & 4483.25 & 2.68 \\
\hline arbor-test & $04 / 30 / 83$ & 1216 & 3.329 & 4486.90 & 4483.22 & 3.68 \\
\hline arbor-test & $03 / 26 / 84$ & 1547 & 4.235 & 4489.10 & 4483.77 & 5.33 \\
\hline arbor-test & $05 / 01 / 85$ & 1948 & 5.333 & 4490.60 & 4484.97 & 5.63 \\
\hline arbor-test & $04 / 19 / 86$ & 2301 & 6.300 & 4490.20 & 4485.45 & 4.75 \\
\hline arbor-test & $05 / 04 / 87$ & 2681 & 7.340 & 4490.30 & 4485.34 & 4.96 \\
\hline arbor-test & $04 / 27 / 89$ & 3405 & 9.322 & 4488.40 & 4484.47 & 3.93 \\
\hline arbor-test & $03 / 15 / 90$ & 3727 & 10.204 & 4488.30 & 4484.09 & 4.21 \\
\hline
\end{tabular}




\begin{tabular}{|c|c|c|c|c|c|c|}
\hline arco-test & $03 / 15 / 80$ & 75 & 0.205 & 4799.40 & 4803.31 & -3.91 \\
\hline arco-test & $05 / 19 / 81$ & 505 & 1.383 & 4800.40 & 4806.94 & -6.54 \\
\hline arco-test & $03 / 24 / 82$ & 814 & 2.229 & 4800.55 & 4807.32 & -6.77 \\
\hline arco-test & $03 / 18 / 83$ & 1173 & 3.211 & 4804.50 & 4807.74 & -3.24 \\
\hline arco-test & $03 / 05 / 84$ & 1526 & 4.178 & 4808.50 & 4810.17 & -1.67 \\
\hline arco-test & $03 / 26 / 85$ & 1912 & 5.235 & 4811.60 & 4811.46 & 0.15 \\
\hline arco-test & $03 / 19 / 86$ & 2270 & 6.215 & 4808.70 & 4811.38 & -2.68 \\
\hline arco-test & $06 / 09 / 87$ & 2717 & 7.439 & 4806.70 & 4808.60 & -1.90 \\
\hline arco-test & $03 / 10 / 88$ & 2992 & 8.192 & 4806.00 & 4809.95 & -3.95 \\
\hline arco-test & $03 / 22 / 90$ & 3734 & 10.223 & 4793.30 & 4801.07 & -7.77 \\
\hline arco-test & $03 / 31 / 89$ & 3378 & 9.248 & 4799.70 & 4806.10 & -6.40 \\
\hline area-II & $03 / 18 / 80$ & 78 & 0.214 & 4461.00 & 4468.45 & -7.45 \\
\hline area-II & $03 / 22 / 88$ & 3004 & 8.225 & 4464.60 & 4469.70 & -5.10 \\
\hline area-II & $03 / 29 / 89$ & 3376 & 9.243 & 4462.90 & 4468.96 & -6.06 \\
\hline area-II & $03 / 21 / 90$ & 3733 & 10.220 & 4462.30 & 4468.46 & -6.16 \\
\hline cerro-g & $03 / 19 / 80$ & 79 & 0.216 & 4426.20 & 4432.16 & -5.96 \\
\hline cerro-g & $04 / 02 / 81$ & 458 & 1.254 & 4426.25 & 4431.23 & -4.98 \\
\hline cerro-g & $03 / 18 / 82$ & 808 & 2.212 & 4426.19 & 4430.89 & -4.70 \\
\hline cerro-g & $03 / 23 / 83$ & 1178 & 3.225 & 4427.70 & 4431.18 & -3.48 \\
\hline cerro-g & $03 / 21 / 84$ & 1542 & 4.222 & 4431.50 & 4434.97 & -3.47 \\
\hline cerro-g & $04 / 18 / 85$ & 1935 & 5.298 & 4432.20 & 4437.40 & -5.20 \\
\hline cerro-g & $04 / 22 / 86$ & 2304 & 6.308 & 4429.70 & 4435.14 & -5.44 \\
\hline cerro-g & $04 / 08 / 87$ & 2655 & 7.269 & 4429.60 & 4433.72 & -4.12 \\
\hline cerro-g & $04 / 05 / 88$ & 3018 & 8.263 & 4428.20 & 4432.86 & -4.66 \\
\hline cerro-g & $05 / 01 / 89$ & 3409 & 9.333 & 4426.90 & 4432.01 & -5.11 \\
\hline cerro-g & $04 / 27 / 90$ & 3770 & 10.322 & 4426.20 & 4431.53 & -5.33 \\
\hline hwy-2 & $03 / 18 / 80$ & 78 & 0.214 & 4494.40 & 4502.76 & -8.36 \\
\hline hwy-2 & $03 / 31 / 81$ & 456 & 1.248 & 4493.69 & 4502.56 & -8.87 \\
\hline hwy-2 & $03 / 26 / 82$ & 816 & 2.234 & 4493.64 & 4502.36 & -8.72 \\
\hline hwy-2 & $04 / 30 / 83$ & 1216 & 3.329 & 4494.40 & 4502.26 & -7.86 \\
\hline hwy-2 & $03 / 26 / 84$ & 1547 & 4.235 & 4496.50 & 4502.55 & -6.04 \\
\hline hwy-2 & $04 / 01 / 85$ & 1918 & 5.251 & 4498.00 & 4503.39 & -5.39 \\
\hline hwy-2 & $04 / 19 / 86$ & 2301 & 6.300 & 4497.60 & 4503.86 & -6.26 \\
\hline
\end{tabular}




\begin{tabular}{|c|c|c|c|c|c|c|}
\hline hwy-2 & $05 / 04 / 87$ & 2681 & 7.340 & 4497.50 & 4503.82 & -6.32 \\
\hline hwy-2 & $04 / 26 / 88$ & 3039 & 8.320 & 4497.10 & 4503.62 & -6.52 \\
\hline hwy-2 & $04 / 08 / 89$ & 3386 & 9.270 & 4496.10 & 4503.32 & -7.22 \\
\hline hwy-2 & $04 / 16 / 90$ & 3759 & 10.292 & 4495.90 & 4503.01 & -7.11 \\
\hline mtr-test & $03 / 31 / 80$ & 91 & 0.249 & 4459.30 & 4462.39 & -3.09 \\
\hline mtr-test & $03 / 31 / 81$ & 456 & 1.248 & 4458.82 & 4461.19 & -2.37 \\
\hline mtr-test & $03 / 31 / 82$ & 821 & 2.248 & 4458.52 & 4460.62 & -2.10 \\
\hline mtr-test & $03 / 31 / 83$ & 1186 & 3.247 & 4460.10 & 4462.50 & -2.40 \\
\hline mtr-test & $03 / 31 / 84$ & 1552 & 4.249 & 4463.00 & 4465.90 & -2.90 \\
\hline mtr-test & $04 / 01 / 85$ & 1918 & 5.251 & 4465.80 & 4468.33 & -2.53 \\
\hline mtr-test & $04 / 24 / 86$ & 2306 & 6.313 & 4465.70 & 4467.91 & -2.21 \\
\hline mtr-test & $03 / 27 / 87$ & 2643 & 7.236 & 4465.80 & 4466.48 & -0.68 \\
\hline mtr-test & $03 / 22 / 88$ & 3004 & 8.225 & 4463.80 & 4464.45 & -0.65 \\
\hline mtr-test & $03 / 20 / 89$ & 3367 & 9.218 & 4461.80 & 4462.75 & -0.95 \\
\hline mtr-test & $04 / 02 / 90$ & 3745 & 10.253 & 4460.50 & 4461.78 & -1.28 \\
\hline simplot-1 & $03 / 26 / 80$ & 86 & 0.235 & 4684.60 & 4683.97 & 0.63 \\
\hline simplot-1 & $03 / 24 / 81$ & 449 & 1.229 & 4684.25 & 4684.49 & -0.24 \\
\hline simplot-1 & $03 / 24 / 82$ & 814 & 2.229 & 4684.66 & 4684.06 & 0.60 \\
\hline simplot-1 & $03 / 17 / 83$ & 1172 & 3.209 & 4684.80 & 4684.52 & 0.28 \\
\hline simplot-1 & $03 / 14 / 84$ & 1535 & 4.203 & 4687.00 & 4687.07 & -0.07 \\
\hline simplot-1 & $03 / 12 / 85$ & 1898 & 5.196 & 4688.60 & 4689.88 & -1.28 \\
\hline simplot-1 & $03 / 18 / 86$ & 2269 & 6.212 & 4686.50 & 4690.63 & -4.13 \\
\hline simplot-1 & $03 / 03 / 87$ & 2619 & 7.170 & 4687.40 & 4691.17 & -3.77 \\
\hline simplot-1 & $03 / 07 / 88$ & 2989 & 8.183 & 4686.50 & 4690.90 & -4.40 \\
\hline simplot-1 & $03 / 29 / 89$ & 3376 & 9.243 & 4685.10 & 4688.86 & -3.76 \\
\hline simplot-1 & $03 / 01 / 90$ & 3713 & 10.166 & 4684.90 & 4687.73 & -2.83 \\
\hline site-09 & $03 / 18 / 80$ & 78 & 0.214 & 4454.40 & 4451.77 & 2.63 \\
\hline site-09 & $03 / 31 / 81$ & 456 & 1.248 & 4454.05 & 4450.84 & 3.21 \\
\hline site-09 & $03 / 24 / 82$ & 814 & 2.229 & 4453.82 & 4450.39 & 3.43 \\
\hline site-09 & $04 / 29 / 83$ & 1215 & 3.326 & 4455.30 & 4450.93 & 4.37 \\
\hline site-09 & $03 / 23 / 84$ & 1544 & 4.227 & 4457.80 & 4453.06 & 4.74 \\
\hline site-09 & $04 / 18 / 85$ & 1935 & 5.298 & 4459.90 & 4455.72 & 4.18 \\
\hline
\end{tabular}




\begin{tabular}{|c|c|c|c|c|c|c|}
\hline site-09 & $04 / 28 / 86$ & 2310 & 6.324 & 4458.40 & 4455.19 & 3.21 \\
\hline site-09 & $04 / 09 / 87$ & 2656 & 7.272 & 4458.70 & 4454.07 & 4.63 \\
\hline site- 09 & $04 / 04 / 88$ & 3017 & 8.260 & 4457.90 & 4453.04 & 4.86 \\
\hline site-09 & $04 / 05 / 89$ & 3383 & 9.262 & 4456.20 & 4451.94 & 4.26 \\
\hline site-09 & $04 / 26 / 90$ & 3769 & 10.319 & 4455.30 & 4451.25 & 4.06 \\
\hline site-14 & $03 / 17 / 80$ & 77 & 0.211 & 4526.00 & 4506.49 & 19.50 \\
\hline site-14 & $03 / 27 / 81$ & 452 & 1.238 & 4526.27 & 4505.73 & 20.50 \\
\hline site-14 & $03 / 29 / 82$ & 819 & 2.242 & 4525.37 & 4505.24 & 20.10 \\
\hline site-14 & $03 / 14 / 83$ & 1169 & 3.201 & 4529.20 & 4505.78 & 23.40 \\
\hline site-14 & $03 / 28 / 84$ & 1549 & 4.241 & 4533.40 & 4507.43 & 26.00 \\
\hline site-14 & $04 / 19 / 85$ & 1936 & 5.300 & 4534.10 & 4508.75 & 25.40 \\
\hline site-14 & $05 / 02 / 86$ & 2314 & 6.335 & 4533.30 & 4509.51 & 23.80 \\
\hline site-14 & $05 / 01 / 87$ & 2678 & 7.332 & 4535.80 & 4509.51 & 26.30 \\
\hline site-14 & $04 / 08 / 88$ & 3021 & 8.271 & 4532.70 & 4508.70 & 24.00 \\
\hline site-14 & $04 / 18 / 89$ & 3396 & 9.298 & 4530.50 & 4507.46 & 23.00 \\
\hline \multirow[t]{2}{*}{ site-14 } & $03 / 14 / 90$ & 3726 & 10.201 & 4529.30 & 4506.77 & 22.50 \\
\hline & & & & & & $\cdot$ \\
\hline usgs-001 & $03 / 18 / 80$ & 78 & 0.214 & 4435.50 & 4445.41 & -9.91 \\
\hline usgs-001 & $03 / 26 / 81$ & 451 & 1.235 & 4435.46 & 4444.91 & -9.45 \\
\hline usgs-001 & $03 / 22 / 82$ & 812 & 2.223 & 4435.20 & 4444.62 & -9.42 \\
\hline usgs-001 & $03 / 23 / 83$ & 1178 & 3.225 & 4436.30 & 4444.60 & -8.30 \\
\hline usgs-001 & $03 / 22 / 84$ & 1543 & 4.225 & 4438.60 & 4445.75 & -7.15 \\
\hline usgs-001 & $03 / 25 / 85$ & 1911 & 5.232 & 4440.20 & 4447.55 & -7.35 \\
\hline usgs-001 & $03 / 24 / 86$ & 2275 & 6.229 & 4438.80 & 4447.43 & -8.63 \\
\hline usgs-001 & $03 / 27 / 87$ & 2643 & 7.236 & 4438.50 & 4446.69 & -8.19 \\
\hline usgs-001 & $03 / 22 / 88$ & 3004 & 8.225 & 4437.90 & 4446.22 & -8.32 \\
\hline usgs-001 & $03 / 20 / 89$ & 3367 & 9.218 & 4436.30 & 4445.68 & -9.38 \\
\hline usgs-001 & $03 / 20 / 90$ & 3732 & 10.218 & 4436.00 & 4445.28 & -9.28 \\
\hline usgs-002 & $03 / 18 / 80$ & 78 & 0.214 & 4468.70 & 4473.29 & -4.59 \\
\hline usgs-002 & $03 / 27 / 81$ & 452 & 1.238 & 4468.34 & 4472.89 & -4.55 \\
\hline usgs-002 & $04 / 02 / 82$ & 823 & 2.253 & 4467.90 & 4472.58 & -4.68 \\
\hline usgs- 002 & $04 / 29 / 83$ & 1215 & 3.326 & 4469.10 & 4472.61 & -3.51 \\
\hline usgs-002 & $03 / 27 / 84$ & 1548 & 4.238 & 4471.40 & 4473.31 & -1.91 \\
\hline
\end{tabular}




\begin{tabular}{|c|c|c|c|c|c|c|}
\hline usgs-002 & $04 / 22 / 85$ & 1939 & 5.309 & 4473.40 & 4474.65 & -1.25 \\
\hline usgs-002 & $05 / 02 / 86$ & 2314 & 6.335 & 4472.70 & 4475.09 & -2.39 \\
\hline usgs -002 & $05 / 04 / 87$ & 2681 & 7.340 & 4472.70 & 4474.84 & -2.14 \\
\hline usgs -002 & $04 / 26 / 88$ & 3039 & 8.320 & 4472.00 & 4474.40 & -2.40 \\
\hline usgs-002 & $04 / 27 / 89$ & 3405 & 9.322 & 4470.50 & 4473.80 & -3.30 \\
\hline usgs-002 & $04 / 26 / 90$ & 3769 & 10.319 & 4470.00 & 4473.36 & -3.36 \\
\hline usgs-004 & $03 / 13 / 80$ & 73 & 0.200 & 4533.60 & 4573.81 & -40.20 \\
\hline usgs-004 & $03 / 23 / 81$ & 448 & 1.227 & 4532.97 & 4573.66 & -40.70 \\
\hline usgs-004 & $03 / 29 / 82$ & 819 & 2.242 & 4532.61 & 4573.42 & -40.80 \\
\hline usgs -004 & $03 / 16 / 83$ & 1171 & 3.206 & 4533.70 & 4573.25 & -39.50 \\
\hline usgs-004 & $03 / 28 / 84$ & 1549 & 4.241 & 4535.40 & 4573.39 & -38.00 \\
\hline usgs-004 & $05 / 07 / 86$ & 2319 & 6.349 & 4538.30 & 4574.51 & -36.20 \\
\hline usgs-004 & $03 / 20 / 87$ & 2636 & 7.217 & 4538.40 & 4574.94 & -36.50 \\
\hline usgs-004 & $04 / 29 / 88$ & 3042 & 8.329 & 4536.70 & 4575.27 & -38.60 \\
\hline usgs-004 & $04 / 26 / 89$ & 3404 & 9.320 & 4534.70 & 4575.25 & -40.50 \\
\hline usgs-004 & $04 / 13 / 90$ & 3756 & 10.283 & 4535.00 & 4575.06 & -40.10 \\
\hline usgs-005 & $03 / 18 / 80$ & 78 & 0.214 & 4471.20 & 4474.88 & -3.68 \\
\hline usgs-005 & $04 / 22 / 81$ & 478 & 1.309 & 4470.51 & 4473.98 & -3.47 \\
\hline usgs-005 & $03 / 25 / 82$ & 815 & 2.231 & 4470.41 & 4473.55 & -3.14 \\
\hline usgs-005 & $03 / 30 / 83$ & 1185 & 3.244 & 4471.00 & 4474.62 & -3.62 \\
\hline usgs-005 & $03 / 23 / 84$ & 1544 & 4.227 & 4473.30 & 4476.31 & -3.00 \\
\hline usgs-005 & $04 / 22 / 85$ & 1939 & 5.309 & 4476.60 & 4478.14 & -1.53 \\
\hline usgs-005 & $05 / 02 / 86$ & 2314 & 6.335 & 4476.90 & 4478.57 & -1.67 \\
\hline usgs-005 & $05 / 01 / 87$ & 2678 & 7.332 & 4477.50 & 4478.00 & -0.50 \\
\hline usgs-005 & $03 / 21 / 88$ & 3003 & 8.222 & 4476.80 & 4476.79 & 0.01 \\
\hline usgs-005 & $03 / 28 / 89$ & 3375 & 9.240 & 4474.90 & 4475.41 & -0.51 \\
\hline usgs-005 & $04 / 02 / 90$ & 3745 & 10.253 & 4473.10 & 4474.64 & -1.54 \\
\hline usgs-006 & $03 / 17 / 80$ & 77 & 0.211 & 4486.30 & 4494.34 & -8.04 \\
\hline usgs-006 & $03 / 27 / 81$ & 452 & 1.238 & 4486.21 & 4493.64 & -7.43 \\
\hline usgs-006 & $03 / 17 / 82$ & 807 & 2.209 & 4485.70 & 4493.19 & -7.49 \\
\hline usgs-006 & $03 / 16 / 83$ & 1171 & 3.206 & 4486.70 & 4493.69 & -6.99 \\
\hline usgs-006 & $03 / 27 / 84$ & 1548 & 4.238 & 4488.80 & 4495.17 & -6.37 \\
\hline usgs-006 & $04 / 19 / 85$ & 1936 & 5.300 & 4491.20 & 4496.54 & -5.34 \\
\hline
\end{tabular}




\begin{tabular}{|c|c|c|c|c|c|c|}
\hline usgs-006 & $05 / 07 / 86$ & 2319 & 6.349 & 4490.80 & 4497.25 & -6.45 \\
\hline usgs-006 & $03 / 27 / 87$ & 2643 & 7.236 & 4491.30 & 4497.17 & -5.87 \\
\hline usgs-007 & $03 / 15 / 80$ & 75 & 0.205 & 4578.40 & 4566.82 & 11.60 \\
\hline usgs-007 & $03 / 27 / 81$ & 452 & 1.238 & 4578.11 & 4566.41 & 11.70 \\
\hline usgs-007 & $03 / 29 / 82$ & 819 & 2.242 & 4577.44 & 4566.06 & 11.40 \\
\hline usgs-007 & $03 / 14 / 83$ & 1169 & 3.201 & 4577.10 & 4566.10 & 11.00 \\
\hline usgs-007 & $03 / 28 / 84$ & 1549 & 4.241 & 4579.10 & 4566.73 & 12.40 \\
\hline usgs-007 & $03 / 05 / 85$ & 1891 & 5.177 & 4581.20 & 4567.39 & 13.80 \\
\hline usgs-007 & $05 / 07 / 86$ & 2319 & 6.349 & 4583.70 & 4568.29 & 15.40 \\
\hline usgs-007 & $05 / 01 / 87$ & 2678 & 7.332 & 4585.00 & 4568.86 & 16.10 \\
\hline usgs-007 & $03 / 21 / 88$ & 3003 & 8.222 & 4585.00 & 4569.01 & 16.00 \\
\hline usgs-007 & $03 / 30 / 89$ & 3377 & 9.246 & 4583.30 & 4568.74 & 14.60 \\
\hline usgs-007 & $03 / 20 / 90$ & 3732 & 10.218 & 4582.60 & 4568.38 & 14.20 \\
\hline usgs-008 & $03 / 19 / 80$ & 79 & 0.216 & 4430.10 & 4422.15 & 7.95 \\
\hline usgs-008 & $04 / 09 / 81$ & 465 & 1.273 & 4430.76 & 4420.84 & 9.92 \\
\hline usgs-008 & $03 / 19 / 82$ & 809 & 2.215 & 4430.33 & 4420.42 & 9.91 \\
\hline usgs-008 & $04 / 14 / 83$ & 1200 & 3.285 & 4434.50 & 4421.76 & 12.70 \\
\hline usgs -008 & $03 / 20 / 84$ & 1541 & 4.219 & 4438.60 & 4429.81 & 8.79 \\
\hline usgs-008 & $04 / 17 / 85$ & 1934 & 5.295 & 4438.90 & 4432.32 & 6.58 \\
\hline usgs-008 & $04 / 22 / 86$ & 2304 & 6.308 & 4434.60 & 4427.09 & 7.51 \\
\hline usgs-008 & $04 / 06 / 87$ & 2653 & 7.264 & 4435.00 & 4424.70 & 10.30 \\
\hline usgs-008 & $04 / 05 / 88$ & 3018 & 8.263 & 4432.80 & 4423.21 & 9.59 \\
\hline usgs-008 & $05 / 01 / 89$ & 3409 & 9.333 & 4430.90 & 4421.70 & 9.20 \\
\hline usgs-008 & $04 / 05 / 90$ & 3748 & 10.261 & 4429.90 & 4421.04 & 8.86 \\
\hline usgs-009 & $03 / 31 / 80$ & 91 & 0.249 & 4425.20 & 4423.84 & 1.36 \\
\hline usgs-009 & $03 / 31 / 81$ & 456 & 1.248 & 4425.21 & 4422.56 & 2.65 \\
\hline usgs-009 & $03 / 31 / 82$ & 821 & 2.248 & 4425.12 & 4422.14 & 2.98 \\
\hline usgs-009 & $03 / 31 / 83$ & 1186 & 3.247 & 4427.40 & 4423.87 & 3.53 \\
\hline usgs-009 & $03 / 31 / 84$ & 1552 & 4.249 & 4431.80 & 4438.44 & -6.64 \\
\hline usgs-009 & $03 / 31 / 85$ & 1917 & 5.248 & 4431.80 & 4437.26 & -5.46 \\
\hline usgs-009 & $03 / 31 / 86$ & 2282 & 6.248 & 4428.40 & 4428.44 & -0.04 \\
\hline usgs-009 & $03 / 31 / 87$ & 2647 & 7.247 & 4428.90 & 4426.66 & 2.24 \\
\hline
\end{tabular}




\begin{tabular}{|c|c|c|c|c|c|c|}
\hline usgs-009 & $03 / 22 / 88$ & 3004 & 8.225 & 4427.60 & 4424.70 & 2.90 \\
\hline usgs-009 & $03 / 28 / 89$ & 3375 & 9.240 & 4426.00 & 4423.50 & 2.50 \\
\hline usgs-009 & $03 / 20 / 90$ & 3732 & 10.218 & 4425.30 & 4422.86 & 2.44 \\
\hline usgs-011 & $03 / 19 / 80$ & 79 & 0.216 & 4415.10 & 4418.88 & -3.78 \\
\hline usgs-011 & $04 / 02 / 81$ & 458 & 1.254 & 4415.27 & 4417.72 & -2.45 \\
\hline usgs-011 & $04 / 16 / 82$ & 837 & 2.292 & 4414.96 & 4417.33 & -2.37 \\
\hline usgs-011 & $03 / 23 / 83$ & 1178 & 3.225 & 4415.30 & 4417.88 & -2.58 \\
\hline usgs-011 & $03 / 21 / 84$ & 1542 & 4.222 & 4419.30 & 4423.60 & -4.30 \\
\hline usgs-011 & $04 / 17 / 85$ & 1934 & 5.295 & 4420.30 & 4426.22 & -5.92 \\
\hline usgs-011 & $04 / 22 / 86$ & 2304 & 6.308 & 4418.40 & 4422.46 & -4.06 \\
\hline usgs-011 & $03 / 13 / 87$ & 2629 & 7.198 & 4418.30 & 4420.67 & -2.37 \\
\hline usgs-011 & $04 / 05 / 88$ & 3018 & 8.263 & 4417.00 & 4419.53 & -2.53 \\
\hline usgs-011 & $05 / 01 / 89$ & 3409 & 9.333 & 4415.80 & 4418.54 & -2.74 \\
\hline usgs-011 & $04 / 03 / 90$ & 3746 & 10.256 & 4415.30 & 4418.02 & -2.72 \\
\hline usgs-012 & $03 / 31 / 80$ & 91 & 0.249 & 4491.90 & 4489.33 & 2.57 \\
\hline usgs-012 & $03 / 31 / 81$ & 456 & 1.248 & 4493.22 & 4488.20 & 5.02 \\
\hline usgs-012 & $03 / 31 / 82$ & 821 & 2.248 & 4491.14 & 4487.61 & 3.53 \\
\hline usgs-012 & $03 / 31 / 83$ & 1186 & 3.247 & 4493.70 & 4490.01 & 3.69 \\
\hline usgs-012 & $03 / 31 / 84$ & 1552 & 4.249 & 4499.20 & 4492.34 & 6.86 \\
\hline usgs-012 & $03 / 31 / 85$ & 1917 & 5.248 & 4503.50 & 4494.21 & 9.29 \\
\hline usgs-012 & $03 / 31 / 86$ & 2282 & 6.248 & 4502.40 & 4494.97 & 7.43 \\
\hline usgs-012 & $03 / 31 / 87$ & 2647 & 7.247 & 4504.80 & 4494.40 & 10.40 \\
\hline usgs-012 & $03 / 31 / 88$ & 3013 & 8.249 & 4501.70 & 4492.16 & 9.54 \\
\hline usgs-012 & $03 / 31 / 89$ & 3378 & 9.248 & 4497.70 & 4490.18 & 7.52 \\
\hline usgs-012 & $03 / 31 / 90$ & 3743 & 10.248 & 4494.60 & 4489.12 & 5.48 \\
\hline usgs-013 & $03 / 31 / 80$ & 91 & 0.249 & 4388.40 & 4391.40 & -3.00 \\
\hline usgs-013 & $04 / 15 / 82$ & 836 & 2.289 & 4389.36 & 4390.11 & -0.75 \\
\hline usgs-013 & $04 / 25 / 83$ & 1211 & 3.316 & 4390.00 & 4390.54 & -0.54 \\
\hline usgs-013 & $03 / 30 / 84$ & 1551 & 4.246 & 4390.90 & 4394.40 & -3.49 \\
\hline usgs- 013 & $04 / 17 / 85$ & 1934 & 5.295 & 4393.10 & 4397.85 & -4.75 \\
\hline usgs-013 & $04 / 22 / 86$ & 2304 & 6.308 & 4393.20 & 4395.46 & -2.26 \\
\hline usgs-013 & $04 / 08 / 87$ & 2655 & 7.269 & 4392.70 & 4393.42 & -0.72 \\
\hline
\end{tabular}




\begin{tabular}{|c|c|c|c|c|c|c|}
\hline usgs-013 & $04 / 05 / 88$ & 3018 & 8.263 & 4391.80 & 4392.39 & -0.59 \\
\hline usgs -013 & $05 / 01 / 89$ & 3409 & 9.333 & 4390.80 & 4391.41 & -0.61 \\
\hline usgs- 013 & $04 / 30 / 90$ & 3773 & 10.330 & 4389.70 & 4390.82 & -1.12 \\
\hline usgs-014 & $03 / 19 / 80$ & 79 & 0.216 & 4417.80 & 4427.13 & -9.33 \\
\hline usgs-014 & $04 / 02 / 81$ & 458 & 1.254 & 4417.82 & 4426.49 & -8.67 \\
\hline usgs-014 & $03 / 19 / 82$ & 809 & 2.215 & 4417.68 & 4426.21 & -8.53 \\
\hline usgs-014 & $03 / 23 / 83$ & 1178 & 3.225 & 4418.70 & 4426.25 & -7.55 \\
\hline usgs- 014 & $03 / 21 / 84$ & 1542 & 4.222 & 4421.00 & 4428.05 & -7.05 \\
\hline usgs-014 & $04 / 17 / 85$ & 1934 & 5.295 & 4422.10 & 4430.19 & -8.09 \\
\hline usgs-014 & $04 / 22 / 86$ & 2304 & 6.308 & 4420.80 & 4429.37 & -8.57 \\
\hline usgs- 014 & $04 / 08 / 87$ & 2655 & 7.269 & 4420.40 & 4428.36 & -7.96 \\
\hline usgs-014 & $04 / 05 / 88$ & 3018 & 8.263 & 4419.40 & 4427.79 & -8.39 \\
\hline usgs-014 & $05 / 01 / 89$ & 3409 & 9.333 & 4418.40 & 4427.18 & -8.78 \\
\hline usgs-014 & $04 / 03 / 90$ & 3746 & 10.256 & 4418.00 & 4426.81 & -8.81 \\
\hline usgs- 017 & $03 / 17 / 80$ & 77 & 0.211 & 4479.80 & 4485.03 & -5.23 \\
\hline usgs-017 & $03 / 27 / 81$ & 452 & 1.238 & 4479.52 & 4483.89 & -4.37 \\
\hline usgs-017 & $03 / 29 / 82$ & 819 & 2.242 & 4479.38 & 4483.32 & -3.94 \\
\hline usgs-017 & $03 / 14 / 83$ & 1169 & 3.201 & 4480.40 & 4487.15 & -6.75 \\
\hline usgs-017 & $03 / 27 / 84$ & 1548 & 4.238 & 4483.80 & 4489.19 & -5.39 \\
\hline usgs-017 & $04 / 19 / 85$ & 1936 & 5.300 & 4488.10 & 4490.92 & -2.81 \\
\hline usgs- 017 & $05 / 02 / 86$ & 2314 & 6.335 & 4488.00 & 4491.37 & -3.37 \\
\hline usgs-017 & $03 / 27 / 87$ & 2643 & 7.236 & 4489.10 & 4490.58 & -1.48 \\
\hline usgs-017 & $03 / 21 / 88$ & 3003 & 8.222 & 4487.80 & 4487.55 & 0.26 \\
\hline usgs-017 & $03 / 22 / 89$ & 3369 & 9.224 & 4485.00 & 4485.64 & -0.64 \\
\hline usgs-017 & $03 / 20 / 90$ & 3732 & 10.218 & 4482.20 & 4484.70 & -2.50 \\
\hline usgs-018 & $03 / 17 / 80$ & 77 & 0.211 & 4535.40 & 4539.77 & -4.37 \\
\hline usgs-018 & $03 / 27 / 81$ & 452 & 1.238 & 4535.65 & 4539.31 & -3.66 \\
\hline usgs-018 & $03 / 29 / 82$ & 819 & 2.242 & 4534.83 & 4538.91 & -4.08 \\
\hline usgs -018 & $03 / 14 / 83$ & 1169 & 3.201 & 4538.40 & 4538.90 & -0.50 \\
\hline usgs- 018 & $03 / 28 / 84$ & 1549 & 4.241 & 4542.10 & 4539.74 & 2.37 \\
\hline usgs-018 & $04 / 19 / 85$ & 1936 & 5.300 & 4542.80 & 4540.69 & 2.11 \\
\hline usgs-018 & $05 / 07 / 86$ & 2319 & 6.349 & 4543.00 & 4541.49 & 1.51 \\
\hline
\end{tabular}




\begin{tabular}{|c|c|c|c|c|c|c|}
\hline usgs-018 & $05 / 01 / 87$ & 2678 & 7.332 & 4545.50 & 4541.89 & 3.61 \\
\hline usgs-018 & $03 / 21 / 88$ & 3003 & 8.222 & 4542.30 & 4541.86 & 0.44 \\
\hline usgs-018 & $03 / 29 / 89$ & 3376 & 9.243 & 4540.10 & 4541.32 & -1.22 \\
\hline usgs-018 & $03 / 22 / 90$ & 3734 & 10.223 & 4539.00 & 4540.81 & -1.81 \\
\hline & & & & & & $\cdot$ \\
\hline usgs-019 & $03 / 31 / 80$ & 91 & 0.249 & 4526.90 & 4534.18 & -7.28 \\
\hline usgs-019 & $03 / 31 / 81$ & 456 & 1.248 & 4535.38 & 4533.44 & 1.94 \\
\hline usgs-019 & $03 / 31 / 82$ & 821 & 2.248 & 4527.11 & 4532.93 & -5.82 \\
\hline usgs-019 & $04 / 05 / 83$ & 1191 & 3.261 & 4534.20 & 4533.31 & 0.89 \\
\hline usgs-019 & $03 / 31 / 84$ & 1552 & 4.249 & 4538.00 & 4535.35 & 2.65 \\
\hline usgs-019 & $03 / 31 / 85$ & 1917 & 5.248 & 4532.50 & 4537.49 & -4.99 \\
\hline usgs-019 & $03 / 31 / 86$ & 2282 & 6.248 & 4541.10 & 4538.74 & 2.36 \\
\hline usgs-019 & $03 / 31 / 87$ & 2647 & 7.247 & 4534.40 & 4538.79 & -4.39 \\
\hline usgs-019 & $03 / 31 / 88$ & 3013 & 8.249 & 4530.60 & 4537.99 & -7.39 \\
\hline usgs-019 & $03 / 31 / 89$ & 3378 & 9.248 & 4527.70 & 4536.34 & -8.64 \\
\hline usgs-019 & $03 / 31 / 90$ & 3743 & 10.248 & 4526.40 & 4535.07 & -8.67 \\
\hline usgs-020 & $03 / 18 / 80$ & 78 & 0.214 & 4456.00 & 4456.02 & -0.02 \\
\hline usgs- 020 & $04 / 22 / 81$ & 478 & 1.309 & 4455.33 & 4454.84 & 0.49 \\
\hline usgs-020 & $03 / 24 / 82$ & 814 & 2.229 & 4455.11 & 4454.37 & 0.74 \\
\hline usgs-020 & $03 / 28 / 83$ & 1183 & 3.239 & 4456.20 & 4455.51 & 0.69 \\
\hline usgs-020 & $03 / 23 / 84$ & 1544 & 4.227 & 4458.50 & 4458.37 & 0.13 \\
\hline usgs-020 & $04 / 18 / 85$ & 1935 & 5.298 & 4461.50 & 4461.08 & 0.42 \\
\hline usgs-020 & $04 / 28 / 86$ & 2310 & 6.324 & 4461.00 & 4460.48 & 0.52 \\
\hline usgs -020 & $04 / 10 / 87$ & 2657 & 7.274 & 4461.20 & 4459.12 & 2.08 \\
\hline usgs- 020 & $04 / 04 / 88$ & 3017 & 8.260 & 4460.30 & 4457.55 & 2.75 \\
\hline usgs -020 & $04 / 01 / 89$ & 3379 & 9.251 & 4458.40 & 4456.16 & 2.24 \\
\hline usgs-020 & $04 / 30 / 90$ & 3773 & 10.330 & 4456.80 & 4455.32 & 1.48 \\
\hline usgs-021 & $04 / 03 / 80$ & 94 & 0.257 & 4508.40 & 4515.60 & -7.20 \\
\hline usgs-021 & $03 / 31 / 81$ & 456 & 1.248 & 4508.21 & 4515.29 & -7.08 \\
\hline usgs-021 & $03 / 31 / 82$ & 821 & 2.248 & 4507.78 & 4514.97 & -7.19 \\
\hline usgs-021 & $03 / 31 / 83$ & 1186 & 3.247 & 4508.70 & 4514.89 & -6.19 \\
\hline usgs-021 & $03 / 31 / 84$ & 1552 & 4.249 & 4510.60 & 4515.44 & -4.84 \\
\hline usgs-021 & $03 / 31 / 85$ & 1917 & 5.248 & 4512.30 & 4516.34 & -4.04 \\
\hline
\end{tabular}




\begin{tabular}{|c|c|c|c|c|c|c|}
\hline usgs-021 & $03 / 31 / 86$ & 2282 & 6.248 & 4512.50 & 4517.02 & -4.52 \\
\hline usgs-021 & $03 / 31 / 87$ & 2647 & 7.247 & 4513.10 & 4517.27 & -4.17 \\
\hline usgs- 021 & $03 / 31 / 88$ & 3013 & 8.249 & 4512.70 & 4517.13 & -4.43 \\
\hline usgs-021 & $03 / 31 / 89$ & 3378 & 9.248 & 4511.00 & 4516.66 & -5.66 \\
\hline usgs- 021 & $03 / 31 / 90$ & 3743 & 10.248 & 4510.80 & 4516.20 & -5.40 \\
\hline usgs- 022 & $03 / 18 / 80$ & 78 & 0.214 & 4439.50 & 4444.57 & -5.07 \\
\hline usgs-022 & $04 / 15 / 81$ & 471 & 1.290 & 4439.23 & 4443.20 & -3.97 \\
\hline usgs-022 & $04 / 08 / 82$ & 829 & 2.270 & 4439.55 & 4442.73 & -3.18 \\
\hline usgs-022 & $03 / 28 / 83$ & 1183 & 3.239 & 4441.40 & 4443.38 & -1.98 \\
\hline usgs-022 & $03 / 21 / 84$ & 1542 & 4.222 & 4446.60 & 4448.05 & -1.45 \\
\hline usgs- 022 & $04 / 18 / 85$ & 1935 & 5.298 & 4448.40 & 4451.88 & -3.48 \\
\hline usgs- 022 & $04 / 02 / 86$ & 2284 & 6.253 & 4444.80 & 4449.77 & -4.97 \\
\hline usgs -022 & $04 / 09 / 87$ & 2656 & 7.272 & 4444.60 & 4447.43 & -2.83 \\
\hline usgs-022 & $04 / 04 / 88$ & 3017 & 8.260 & 4443.10 & 4445.98 & -2.88 \\
\hline usgs-022 & $04 / 05 / 89$ & 3383 & 9.262 & 4440.60 & 4444.58 & -3.98 \\
\hline usgs-022 & $04 / 30 / 90$ & 3773 & 10.330 & 4439.50 & 4443.65 & -4.15 \\
\hline usgs- 023 & $03 / 15 / 80$ & 75 & 0.205 & 4485.70 & 4483.87 & 1.83 \\
\hline usgs-023 & $03 / 27 / 81$ & 452 & 1.238 & 4485.97 & 4482.92 & 3.05 \\
\hline usgs-023 & $03 / 17 / 82$ & 807 & 2.209 & 4484.90 & 4482.35 & 2.55 \\
\hline usgs -023 & $03 / 16 / 83$ & 1171 & 3.206 & 4486.60 & 4482.72 & 3.88 \\
\hline usgs-023 & $03 / 20 / 84$ & 1541 & 4.219 & 4491.20 & 4484.82 & 6.38 \\
\hline usgs-023 & $03 / 07 / 85$ & 1893 & 5.183 & 4496.40 & 4487.24 & 9.17 \\
\hline usgs -023 & $04 / 21 / 86$ & 2303 & 6.305 & 4495.90 & 4488.29 & 7.61 \\
\hline usgs-023 & $03 / 20 / 87$ & 2636 & 7.217 & 4497.70 & 4487.84 & 9.86 \\
\hline usgs -023 & $03 / 22 / 88$ & 3004 & 8.225 & 4495.30 & 4486.67 & 8.63 \\
\hline usgs-023 & $03 / 29 / 89$ & 3376 & 9.243 & 4491.50 & 4485.01 & 6.50 \\
\hline usgs -023 & $03 / 20 / 90$ & 3732 & 10.218 & 4488.60 & 4483.91 & 4.69 \\
\hline usgs -025 & $03 / 31 / 80$ & 91 & 0.249 & 4581.80 & 4576.19 & 5.61 \\
\hline usgs-025 & $03 / 31 / 81$ & 456 & 1.248 & 4581.46 & 4575.89 & 5.57 \\
\hline usgs-025 & $03 / 31 / 82$ & 821 & 2.248 & 4580.67 & 4575.56 & 5.11 \\
\hline usgs-025 & $03 / 31 / 83$ & 1186 & 3.247 & 4580.40 & 4575.43 & 4.97 \\
\hline usgs-025 & $03 / 31 / 84$ & 1552 & 4.249 & 4582.40 & 4575.87 & 6.53 \\
\hline
\end{tabular}




\begin{tabular}{|c|c|c|c|c|c|c|}
\hline usgs- 025 & $03 / 31 / 85$ & 1917 & 5.248 & 4584.60 & 4576.58 & 8.02 \\
\hline usgs-025 & $03 / 31 / 86$ & 2282 & 6.248 & 4586.40 & 4577.40 & 9.00 \\
\hline usgs -025 & $03 / 20 / 87$ & 2636 & 7.217 & 4588.00 & 4578.10 & 9.90 \\
\hline usgs-025 & $03 / 31 / 88$ & 3013 & 8.249 & 4588.50 & 4578.53 & 9.97 \\
\hline usgs- 025 & $03 / 31 / 89$ & 3378 & 9.248 & 4587.10 & 4578.43 & 8.67 \\
\hline usgs-025 & $03 / 31 / 90$ & 3743 & 10.248 & 4586.60 & 4578.12 & 8.48 \\
\hline usgs-026 & $03 / 15 / 80$ & 75 & 0.205 & 4581.60 & 4572.23 & 9.37 \\
\hline usgs -026 & $03 / 27 / 81$ & 452 & 1.238 & 4581.22 & 4571.98 & 9.24 \\
\hline usgs -026 & $03 / 29 / 82$ & 819 & 2.242 & 4580.56 & 4571.67 & 8.89 \\
\hline usgs- 026 & $03 / 14 / 83$ & 1169 & 3.201 & 4580.10 & 4571.49 & 8.61 \\
\hline usgs-026 & $03 / 28 / 84$ & 1549 & 4.241 & 4581.90 & 4571.81 & 10.10 \\
\hline usgs -026 & $04 / 25 / 85$ & 1942 & 5.317 & 4584.90 & 4572.48 & 12.40 \\
\hline usgs- 026 & $05 / 07 / 86$ & 2319 & 6.349 & 4586.80 & 4573.25 & 13.50 \\
\hline usgs-026 & $05 / 01 / 87$ & 2678 & 7.332 & 4588.10 & 4573.89 & 14.20 \\
\hline usgs-026 & $04 / 28 / 88$ & 3041 & 8.326 & 4588.70 & 4574.27 & 14.40 \\
\hline usgs -026 & $04 / 13 / 90$ & 3756 & 10.283 & 4586.30 & 4573.96 & 12.30 \\
\hline usgs-027 & $03 / 13 / 80$ & 73 & 0.200 & 4561.40 & 4569.45 & -8.05 \\
\hline usgs- 027 & $03 / 31 / 82$ & 821 & 2.248 & 4560.54 & 4568.99 & -8.44 \\
\hline usgs-027 & $03 / 31 / 83$ & 1186 & 3.247 & 4560.80 & 4568.80 & -8.00 \\
\hline usgs-027 & $03 / 31 / 84$ & 1552 & 4.249 & 4562.40 & 4569.00 & -6.60 \\
\hline usgs- 027 & $03 / 31 / 85$ & 1917 & 5.248 & 4564.00 & 4569.54 & -5.54 \\
\hline usgs- 027 & $03 / 31 / 86$ & 2282 & 6.248 & 4564.90 & 4570.19 & -5.29 \\
\hline usgs- 027 & $03 / 31 / 87$ & 2647 & 7.247 & 4566.00 & 4570.77 & -4.77 \\
\hline usgs- 027 & $03 / 31 / 88$ & 3013 & 8.249 & 4566.00 & 4571.15 & -5.15 \\
\hline usgs -027 & $03 / 31 / 89$ & 3378 & 9.248 & 4565.00 & 4571.16 & -6.16 \\
\hline usgs-027 & $03 / 31 / 90$ & 3743 & 10.248 & 4564.40 & 4570.94 & -6.54 \\
\hline usgs-029 & $03 / 13 / 80$ & 73 & 0.200 & 4527.70 & 4558.27 & -30.60 \\
\hline usgs-029 & $06 / 02 / 81$ & 519 & 1.421 & 4525.46 & 4558.10 & -32.60 \\
\hline usgs-029 & $07 / 13 / 82$ & 925 & 2.533 . & 4522.89 & 4557.88 & -35.00 \\
\hline usgs- 029 & $07 / 21 / 83$ & 1298 & 3.554 & 4524.30 & 4557.80 & -33.50 \\
\hline usgs-029 & $08 / 06 / 84$ & 1680 & 4.600 & 4526.90 & 4558.12 & -31.20 \\
\hline usgs -029 & $07 / 18 / 85$ & 2026 & 5.547 & 4528.80 & 4558.64 & -29.80 \\
\hline
\end{tabular}




\begin{tabular}{|c|c|c|c|c|c|c|}
\hline usgs-029 & $11 / 20 / 86$ & 2516 & 6.888 & 4530.80 & 4559.21 & -28.40 \\
\hline usgs-029 & $08 / 08 / 87$ & 2777 & 7.603 & 4527.90 & 4559.34 & -31.40 \\
\hline usgs-029 & $04 / 29 / 88$ & 3042 & 8.329 & 4530.70 & 4559.35 & -28.70 \\
\hline usgs-029 & $04 / 17 / 89$ & 3395 & 9.295 & 4529.10 & 4559.20 & -30.10 \\
\hline usgs-029 & $04 / 13 / 90$ & 3756 & 10.283 & 4529.30 & 4558.96 & -29.70 \\
\hline usgs- $030 \mathrm{c}$ & $03 / 13 / 80$ & 73 & 0.200 & 4528.60 & 4559.24 & -30.60 \\
\hline usgs-030c & $03 / 23 / 81$ & 448 & 1.227 & 4528.04 & 4559.07 & -31.00 \\
\hline usgs-030c & $03 / 29 / 82$ & 819 & 2.242 & 4527.68 & 4558.82 & -31.10 \\
\hline usgs-030c & $03 / 16 / 83$ & 1171 & 3.206 & 4528.60 & 4558.65 & -30.00 \\
\hline usgs- $030 \mathrm{c}$ & $03 / 28 / 84$ & 1549 & 4.241 & 4530.40 & 4558.82 & -28.40 \\
\hline usgs-030c & $04 / 25 / 85$ & 1942 & $5.3 i 7$ & 4534.40 & 4559.40 & -25.00 \\
\hline usgs-030c & $05 / 07 / 86$ & 2319 & 6.349 & 4535.00 & 4560.03 & -25.00 \\
\hline usgs-030c & $03 / 20 / 87$ & 2636 & 7.217 & 4533.30 & 4560.44 & -27.10 \\
\hline usgs-030c & $04 / 29 / 88$ & 3042 & 8.329 & 4531.90 & 4560.72 & -28.80 \\
\hline usgs-030c & $04 / 17 / 89$ & 3395 & 9.295 & 4530.20 & 4560.66 & -30.50 \\
\hline usgs-039 & $03 / 31 / 80$ & 91 & 0.249 & 4458.00 & 4455.44 & 2.57 \\
\hline usgs-039 & $07 / 24 / 81$ & 571 & 1.563 & 4456.94 & 4454.00 & 2.94 \\
\hline usgs-039 & $07 / 19 / 82$ & 931 & 2.549 & 4456.97 & 4453.57 & 3.40 \\
\hline usgs-039 & $07 / 27 / 83$ & 1304 & 3.570 & 4459.20 & 4456.11 & 3.09 \\
\hline usgs-039 & $04 / 10 / 84$ & 1562 & 4.277 & 4461.50 & 4459.74 & 1.76 \\
\hline usgs-039 & $04 / 22 / 85$ & 1939 & 5.309 & 4464.10 & 4461.91 & 2.19 \\
\hline usgs-039 & $11 / 18 / 86$ & 2514 & 6.883 & 4463.80 & 4459.72 & 4.08 \\
\hline usgs-039 & $04 / 22 / 87$ & 2669 & 7.307 & 4463.80 & 4459.00 & 4.80 \\
\hline usgs-039 & $04 / 06 / 88$ & 3019 & 8.266 & 4462.00 & 4457.09 & 4.91 \\
\hline usgs-039 & $03 / 31 / 89$ & 3378 & 9.248 & 4460.10 & 4455.58 & 4.52 \\
\hline usgs-039 & $04 / 24 / 90$ & 3767 & 10.313 & 4458.70 & 4454.68 & 4.02 \\
\hline usgs- 040 & $03 / 31 / 80$ & 91 & 0.249 & 4458.60 & 4460.00 & -1.40 \\
\hline usgs- 040 & $03 / 31 / 81$ & 456 & 1.248 & 4458.05 & 4458.82 & -0.77 \\
\hline usgs -040 & $03 / 29 / 82$ & 819 . & 2.242 & 4457.78 & 4458.28 & -0.50 \\
\hline usgs -040 & $03 / 28 / 83$ & 1183 & 3.239 & 4458.50 & 4460.44 & -1.94 \\
\hline usgs -040 & $03 / 22 / 84$ & 1543 & 4.225 & 4462.00 & 4463.96 & -1.96 \\
\hline usgs -040 & $04 / 02 / 85$ & 1919 & 5.254 & 4466.10 & 4466.23 & -0.13 \\
\hline
\end{tabular}




\begin{tabular}{|c|c|c|c|c|c|c|}
\hline usgs-040 & $04 / 29 / 86$ & 2311 & 6.327 & 4464.10 & 4465.59 & -1.49 \\
\hline usgs-040 & $03 / 27 / 87$ & 2643 & 7.236 & 4464.80 & 4464.06 & 0.74 \\
\hline usgs -040 & $04 / 14 / 88$ & 3027 & 8.287 & 4462.90 & 4461.75 & 1.15 \\
\hline usgs-040 & $03 / 20 / 89$ & 3367 & 9.218 & 4460.60 & 4460.27 & 0.33 \\
\hline usgs- 040 & $04 / 02 / 90$ & 3745 & 10.253 & 4459.20 & 4459.37 & -0.17 \\
\hline usgs-076 & $07 / 24 / 80$ & 206 & 0.564 & 4456.80 & 4457.21 & -0.41 \\
\hline usgs-076 & $07 / 13 / 81$ & 560 & 1.533 & 4456.89 & 4456.28 & 0.61 \\
\hline usgs-076 & $07 / 15 / 83$ & 1292 & 3.537 & 4459.00 & 4458.59 & 0.41 \\
\hline usgs-076 & $04 / 26 / 84$ & 1578 & 4.320 & 4461.60 & 4462.61 & -1.01 \\
\hline usgs-076 & $04 / 25 / 85$ & 1942 & 5.317 & 4463.90 & 4464.40 & -0.50 \\
\hline usgs-076 & $04 / 24 / 86$ & 2306 & 6.313 & 4463.60 & 4463.41 & 0.19 \\
\hline usgs-076 & $04 / 23 / 87$ & 2670 & 7.310 & 4463.80 & 4461.54 & 2.26 \\
\hline usgs-076 & $04 / 12 / 88$ & 3025 & 8.282 & 4461.80 & 4459.44 & 2.36 \\
\hline usgs-076 & $04 / 07 / 89$ & 3385 & 9.268 & 4459.80 & 4457.89 & 1.91 \\
\hline usgs-076 & $04 / 06 / 90$ & 3749 & 10.264 & 4458.40 & 4457.01 & 1.39 \\
\hline usgs- 077 & $03 / 18 / 80$ & 78 & 0.214 & 4457.30 & 4455.50 & 1.80 \\
\hline usgs-077 & $07 / 28 / 81$ & 575 & 1.574 & 4456.67 & 4454.06 & 2.61 \\
\hline usgs-077 & $07 / 19 / 82$ & 931 & 2.549 & 4456.90 & 4453.64 & 3.26 \\
\hline usgs-077 & $08 / 01 / 83$ & 1309 & 3.584 & 4459.10 & 4455.89 & 3.21 \\
\hline usgs-077 & $04 / 11 / 84$ & 1563 & 4.279 & 4461.30 & 4458.80 & 2.50 \\
\hline usgs-077 & $04 / 22 / 85$ & 1939 & 5.309 & 4462.90 & 4461.23 & 1.67 \\
\hline usgs-077 & $11 / 13 / 86$ & 2509 & 6.869 & 4463.80 & 4459.42 & 4.38 \\
\hline usgs-077 & $04 / 10 / 87$ & 2657 & 7.274 & 4463.80 & 4458.80 & 5.00 \\
\hline usgs-077 & $04 / 04 / 88$ & 3017 & 8.260 & 4462.00 & 4457.05 & 4.95 \\
\hline usgs-077 & $03 / 31 / 89$ & 3378 & 9.248 & 4460.10 & 4455.59 & 4.51 \\
\hline usgs-077 & $07 / 26 / 90$ & 3860 & 10.568 & 4458.00 & 4454.62 & 3.39 \\
\hline usgs-079 & $07 / 24 / 80$ & 206 & 0.564 & 4458.00 & 4458.60 & -0.60 \\
\hline usgs-079 & $07 / 28 / 81$ & 575 & 1.574 & 4457.98 & 4457.63 & 0.35 \\
\hline usgs-079 & $07 / 21 / 82$ & 933 & 2.554 & 4457.95 & 4457.18 & 0.77 \\
\hline usgs-079 & $08 / 01 / 83$ & 1309 & 3.584 & 4460.20 & 4459.55 & 0.65 \\
\hline usgs-079 & $04 / 10 / 84$ & 1562 & 4.277 & 4462.50 & 4462.66 & -0.16 \\
\hline usgs-079 & $04 / 25 / 85$ & 1942 & 5.317 & 4465.10 & 4465.16 & -0.06 \\
\hline
\end{tabular}




\begin{tabular}{|c|c|c|c|c|c|c|}
\hline usgs-079 & $04 / 30 / 86$ & 2312 & 6.330 & 4464.70 & 4464.42 & 0.28 \\
\hline usgs-079 & $03 / 31 / 87$ & 2647 & 7.247 & 4464.90 & 4462.85 & 2.05 \\
\hline usgs-079 & $03 / 31 / 88$ & 3013 & 8.249 & 4463.00 & 4460.98 & 2.02 \\
\hline usgs-079 & $03 / 20 / 89$ & 3367 & 9.218 & 4461.00 & 4459.39 & 1.61 \\
\hline usgs-079 & $04 / 26 / 90$ & 3769 & 10.319 & 4459.30 & 4458.38 & 0.92 \\
\hline usgs-086 & $03 / 19 / 80$ & 79 & 0.216 & 4428.70 & 4422.74 & 5.96 \\
\hline usgs-086 & $04 / 09 / 81$ & 465 & 1.273 & 4429.23 & 4421.29 & 7.94 \\
\hline usgs-086 & $03 / 19 / 82$ & 809 & 2.215 & 4428.79 & 4420.86 & 7.93 \\
\hline usgs -086 & $04 / 14 / 83$ & 1200 & 3.285 & 4433.30 & 4422.64 & 10.70 \\
\hline usgs-086 & $03 / 20 / 84$ & 1541 & 4.219 & 4437.80 & 4435.25 & 2.55 \\
\hline usgs-086 & $03 / 28 / 85$ & 1914 & 5.240 & 4438.00 & 4435.78 & 2.23 \\
\hline usgs-086 & $04 / 22 / 86$ & 2304 & 6.308 & 4433.10 & 4427.44 & 5.66 \\
\hline usgs-086 & $04 / 08 / 87$ & 2655 & 7.269 & 4433.60 & 4425.50 & 8.10 \\
\hline usgs-086 & $04 / 13 / 88$ & 3026 & 8.285 & 4431.40 & 4423.54 & 7.86 \\
\hline usgs-086 & $04 / 21 / 89$ & 3399 & 9.306 & 4427.90 & 4422.19 & 5.72 \\
\hline usgs-086 & $04 / 11 / 90$ & 3754 & 10.278 & 4428.60 & 4421.52 & 7.08 \\
\hline usgs-087 & $03 / 31 / 80$ & 91 & 0.249 & 4429.80 & 4427.07 & 2.73 \\
\hline usgs-087 & $03 / 05 / 82$ & 795 & 2.177 & 4429.61 & 4425.31 & 4.30 \\
\hline usgs-087 & $03 / 31 / 83$ & 1186 & 3.247 & 4433.30 & 4427.46 & 5.84 \\
\hline usgs- -087 & $03 / 26 / 84$ & 1547 & 4.235 & 4439.80 & 4444.51 & -4.71 \\
\hline usgs-087 & $03 / 28 / 85$ & 1914 & 5.240 & 4440.10 & 4442.44 & -2.34 \\
\hline usgs- 087 & $04 / 18 / 86$ & 2300 & 6.297 & 4434.10 & 4431.73 & 2.37 \\
\hline usgs-087 & $04 / 01 / 87$ & 2648 & 7.250 & 4435.00 & 4430.28 & 4.72 \\
\hline usgs-087 & $04 / 06 / 88$ & 3019 & 8.266 & 4432.50 & 4427.90 & 4.60 \\
\hline usgs-087 & $04 / 05 / 89$ & 3383 & 9.262 & 4430.60 & 4426.67 & 3.93 \\
\hline usgs-087 & $04 / 04 / 90$ & 3747 & 10.259 & 4430.20 & 4426.00 & 4.20 \\
\hline usgs-089 & $03 / 31 / 80$ & 91 & 0.249 & 4429.50 & 4426.40 & 3.10 \\
\hline usgs-089 & $04 / 08 / 82$ & 829 & 2.270 & 4430.06 & 4424.59 & 5.47 \\
\hline usgs-089 & $03 / 31 / 83$ & 1186 & 3.247 & 4437.10 & 4427.08 & 10.00 \\
\hline usgs-089 & $03 / 26 / 84$ & 1547 & 4.235 & 4448.30 & 4446.43 & 1.87 \\
\hline usgs-089 & $03 / 27 / 85$ & 1913 & 5.238 & 4447.90 & 4443.24 & 4.66 \\
\hline usgs-089 & $04 / 18 / 86$ & 2300 & 6.297 & 4437.20 & 4431.13 & 6.08 \\
\hline
\end{tabular}




\begin{tabular}{|c|c|c|c|c|c|c|}
\hline usgs-089 & $04 / 01 / 87$ & 2648 & 7.250 & 4438.70 & 4429.86 & 8.84 \\
\hline usgs-089 & $04 / 05 / 88$ & 3018 & 8.263 & 4434.60 & 4427.24 & 7.36 \\
\hline usgs-089 & $04 / 04 / 89$ & 3382 & 9.259 & 4431.50 & 4425.99 & 5.51 \\
\hline usgs-089 & $04 / 10 / 90$ & 3753 & 10.275 & 4428.60 & 4425.30 & 3.30 \\
\hline usgs-097 & $03 / 17 / 80$ & 77 & 0.211 & 4479.40 & 4476.33 & 3.07 \\
\hline usgs-097 & $03 / 27 / 81$ & 452 & 1.238 & 4479.15 & 4475.14 & 4.01 \\
\hline usgs-097 & $03 / 24 / 82$ & 814 & 2.229 & 4478.46 & 4474.56 & 3.90 \\
\hline usgs-097 & $03 / 28 / 83$ & 1183 & 3.239 & 4480.00 & 4477.04 & 2.96 \\
\hline usgs-097 & $03 / 19 / 84$ & 1540 & 4.216 & 4483.80 & 4479.32 & 4.48 \\
\hline usgs-097 & $04 / 23 / 85$ & 1940 & 5.311 & 4489.00 & 4481.58 & 7.42 \\
\hline usgs-097 & $04 / 29 / 86$ & 2311 & 6.327 & 4488.80 & 4481.93 & 6.87 \\
\hline usgs-097 & $03 / 27 / 87$ & 2643 & 7.236 & 4490.20 & 4481.07 & 9.13 \\
\hline usgs-097 & 04/01/88 & 3014 & 8.252 & 4488.40 & 4478.68 & 9.72 \\
\hline usgs-097 & $03 / 20 / 89$ & 3367 & 9.218 & 4485.20 & 4476.89 & 8.31 \\
\hline usgs-097 & $03 / 19 / 90$ & 3731 & 10.215 & 4482.20 & 4475.89 & 6.31 \\
\hline usgs-101 & $03 / 18 / 80$ & 78 & 0.214 & 4483.30 & 4478.01 & 5.29 \\
\hline usgs-101 & $07 / 15 / 81$ & 562 & 1.539 & 4481.13 & 4477.59 & 3.54 \\
\hline usgs-101 & $07 / 29 / 82$ & 941 & 2.576 & 4480.89 & 4477.35 & 3.54 \\
\hline usgs-101 & $08 / 01 / 83$ & 1309 & 3.584 & 4482.50 & 4477.44 & 5.06 \\
\hline usgs-101 & $05 / 01 / 84$ & 1583 & 4.334 & 4485.40 & 4478.02 & 7.38 \\
\hline usgs-101 & $04 / 19 / 85$ & 1936 & 5.300 & 4487.40 & 4479.10 & 8.30 \\
\hline usgs-101 & $04 / 18 / 86$ & 2300 & 6.297 & 4483.60 & 4479.54 & 4.06 \\
\hline usgs-101 & $08 / 11 / 87$ & 2780 & 7.611 & 4484.40 & 4479.29 & 5.11 \\
\hline usgs-101 & $04 / 11 / 88$ & 3024 & 8.279 & 4481.90 & 4479.04 & 2.86 \\
\hline usgs-105 & $03 / 31 / 80$ & 91 & 0.249 & 4426.80 & 4427.78 & -0.98 \\
\hline usgs-105 & $04 / 02 / 81$ & 458 & 1.254 & 4426.08 & 4426.67 & -0.59 \\
\hline usgs-105 & $04 / 08 / 82$ & 829 & 2.270 & 4425.82 & 4426.27 & -0.46 \\
\hline usgs-105 & $04 / 18 / 84$ & 1570 & 4.298 & 4434.80 & 4435.57 & -0.77 \\
\hline usgs-105 & $04 / 18 / 85$ & 1935 & 5.298 & 4432.80 & 4436.43 & -3.63 \\
\hline usgs-105 & $04 / 20 / 87$ & 2667 & 7.302 & 4429.60 & 4429.82 & -0.22 \\
\hline usgs-105 & $04 / 13 / 88$ & 3026 & 8.285 & 4428.20 & 4428.50 & -0.30 \\
\hline usgs-105 & $04 / 21 / 89$ & 3399 & 9.306 & 4426.70 & 4427.52 & -0.82 \\
\hline
\end{tabular}




\begin{tabular}{lllllll}
\hline usgs-105 & $04 / 11 / 90$ & 3754 & 10.278 & 4426.00 & 4426.97 & -0.97 \\
usgs-106 & $03 / 31 / 80$ & 91 & 0.249 & 4449.50 & 4431.24 & 18.30 \\
usgs-106 & $03 / 27 / 81$ & 452 & 1.238 & 4428.40 & 4430.02 & -1.62 \\
usgs-106 & $03 / 22 / 82$ & 812 & 2.223 & 4428.03 & 4429.60 & -1.57 \\
usgs-106 & $03 / 28 / 83$ & 1183 & 3.239 & 4430.40 & 4430.55 & -0.15 \\
usgs-106 & $03 / 21 / 84$ & 1542 & 4.222 & 4435.50 & 4438.69 & -3.19 \\
usgs-106 & $04 / 18 / 85$ & 1935 & 5.298 & 4435.60 & 4440.53 & -4.93 \\
usgs-106 & $04 / 19 / 86$ & 2301 & 6.300 & 4431.70 & 4435.40 & -3.70 \\
usgs-106 & $04 / 13 / 88$ & 3026 & 8.285 & 4430.50 & 4432.04 & -1.54 \\
usgs-106 & $04 / 14 / 89$ & 3392 & 9.287 & 4429.10 & 4430.94 & -1.84 \\
usgs-106 & $04 / 02 / 90$ & 3745 & 10.253 & 4429.30 & 4430.33 & -1.03 \\
& & & & & & \\
usgs-107 & $03 / 31 / 80$ & 91 & 0.249 & 4440.30 & 4441.78 & -1.48 \\
usgs-107 & $03 / 27 / 81$ & 452 & 1.238 & 4438.56 & 4440.92 & -2.36 \\
usgs-107 & $03 / 22 / 82$ & 812 & 2.223 & 4438.27 & 4440.52 & -2.25 \\
usgs-107 & $03 / 28 / 83$ & 1183 & 3.239 & 4439.40 & 4440.76 & -1.36 \\
usgs-107 & $03 / 26 / 84$ & 1547 & 4.235 & 4441.90 & 4443.45 & -1.55 \\
usgs-107 & $04 / 18 / 85$ & 1935 & 5.298 & 4443.90 & 4446.12 & -2.22 \\
usgs-107 & $04 / 19 / 86$ & 2301 & 6.300 & 4441.90 & 4444.95 & -3.05 \\
usgs-107 & $04 / 20 / 87$ & 2667 & 7.302 & 4441.80 & 4443.60 & -1.80 \\
usgs-107 & $04 / 07 / 88$ & 3020 & 8.268 & 4441.30 & 4442.76 & -1.46 \\
usgs-107 & $04 / 11 / 89$ & 3389 & 9.279 & 4439.80 & 4441.84 & -2.04 \\
usgs-107 & $04 / 06 / 90$ & 3749 & 10.264 & 4439.20 & 4441.28 & -2.08 \\
\hline & & & & & & \\
\hline
\end{tabular}




\section{Appendix C}

Computational Tools for Regional

Groundwater Flow Model 



\section{Appendix C \\ Computational Tools for Regional Groundwater Flow Model}

\section{VISUALIZATION TOOLS FOR MODFLOWP DATA FILES}

Six tools were developed with PV-WAVE (Visual Numerics 1993) to visualize MODFLOWP data
files.

plot_zones.pro

DESCRIPTION:

This PV-WAVE program creates a new transmissivity zone matrix file based on the existing file and changes made by the user. The new file is in a format that can be used in MODFLOWP.

INPUT FILES:

METHODOLOGY:

SCREEN OUTPUT:

OUTPUT FILES:

USER INTERFACE:

plot_head_contours.pro

DESCRIPTION:

INPUT FILES:

SCREEN OUTPUT:
The input to the program is the existing transmissivity zone matrix file.

Initially, the model domain and the transmissivity zones are plotted on the screen. The user can change the zone number of individual grid blocks by highlighting them on the screen and entering the new value when prompted. After all changes have been made, the new transmissivity zone matrix is written to a file.

A plot of the model domain and the initial transmissivity zones is shown on the screen. After each change to the transmissivity zone matrix, a plot of the model domain and the new transmissivity zones is shown on the screen.

The output file is the new transmissivity zone matrix file.

The user selects grid blocks to be changed to a new zone and also inputs the new zone value.

This PV-WAVE program plots hydraulic head contours of MODFLOWP results to the screen and to a postscript file.

The input to this program is a binary output file from MODFLOWP that contains the calculated hydraulic head values at each node.

A plot of the model domain with colored contours of the calculated head values is shown on the screen. 
OUTPUT FILES:

USER INTERFACE:

compare_heads_to_spin.pro
A black-and-white plot of the model domain and calculated head contours is saved as a postscript file.
DESCRIPTION:

INPUT FILES:

METHODOLOGY:

SCREEN OUTPUT:

OUTPUT FILES:

USER INTERFACE:

plot_resids.pro

DESCRIPTION:
None.

This PV-WAVE program produces a plot showing the difference between the MODFLOWP-calculated heads and the head values calculated in Spinazola (1994a) for the Mud Lake region.

The input files to this program are two binary output files-one that contains the calculated hydraulic head values at each node for the current MODFLOWP run and one containing the calculated hydraulic head values from Spinazola (1994a).

For all grid blocks that are common to the current run and the Spinazola study, the differences in the hydraulic head values are calculated. To calculate the difference, the head from the current MODFLOWP run is subtracted from the head calculated in the Spinazolasstudy. For the blocks outside of the Spinazola domain, the differences are set to zero.

Next the user selects a discretization option containing eight discrete head difference intervals. Each interval is assigned a color. According to the selected discretization option, each block is assigned a color based on the absolute value of the head difference. The model domain is plotted on a color plot with each grid plotted in its assigned color. Grid blocks with negative head differences are outlined in white. The user can select another discretization option if desired.

A plot showing the model domain is shown on the screen. The grid blocks within the Spinazola domain are colored according to the head difference and the discretization option selected.

The user has the option to save the final plot on the screen as a postscript file.

The user selects the discretization option to be used in assigning colors to the grid blocks.

This PV-WAVE program produces a plot showing the difference between hydraulic head values calculated for two separate MODFLOWP runs. 
INPUT FILES:

METHODOLOGY:

SCREEN OUTPUT:

OUTPUT FILES:

USER INTERFACE

plot_differences.pro

DESCRIPTION:

INPUT FILES:

METHODOLOGY:
The input files to this program are two binary files containing the calculated hydraulic head values at each node for two MODFLOWP runs.

The differences in the two hydraulic head values are calculated for each grid block. To calculate the difference, the head from second input file is subtracted from the head in the first input file.

Next the user selects a discretization option containing eight discrete head difference intervals. Each interval is assigned a color. According to the selected discretization option, each block is assigned a color based on the absolute value of the head difference. The model domain is plotted on a color plot with each grid plotted in its assigned color. Grid blocks with negative head differences are outlined in white. The user can select another discretization option if desired.

A plot showing the model domain is shown on the screen. The grid blocks are colored according to the head difference and the discretization option selected.

The user has the option to save the final plot on the screen as a postscript file.

The user selects the discretization option to be used in assigning colors to the grid blocks.

This PV-WAVE program produces a plot showing the difference between hydraulic heads measurements and hydraulic head values calculated by MODFLOWP for all observations wells.

The input files to this program are the transmissivity zone matrix file and the MODFLOWP report file.

The differences between the measured and calculated hydraulic head values are given in the MODFLOWP report file. To calculate the difference, the calculated head is subtracted from the measured head.

The user selects a discretization option containing eight discrete head difference intervals. Each interval is assigned a color. According to the selected discretization option, each well is assigned a color based on the absolute value of the head difference. The model domain is plotted on a color plot. For each well, a circle is plotted in the assigned color. Wells with negative head 
differences are outlined in white (Figures 5-4 and 5-5). The user can select another discretization option if desired.

SCREEN OUTPUT:

A plot showing the model domain is plotted on the screen. The wells are colored according to the head difference and the discretization option selected.

OUTPUT FILES:

The user has the option to save the final plot on the screen as a postscript file.

USER INTERFACE:

The user selects the discretization option to be used in assigning colors to the wells.

plot_sens_contours.pro

DESCRIPTION:

This PV-WAVE program plots contours of sensitivity values calculated from a MODFLOWP sensitivity analysis.

INPUT FILES:

The input to this program is a binary file from MODFLOWP that contains the sensitivity values at all nodes.

SCREEN OUTPUT:

A plot of the model domain with colored contours of the calculated sensitivity values is shown on the screen.

OUTPUT FILES:

A black-and-white plot of the model domain and calculated sensitivity contours is saved as a postscript file. (Figures 6-1 through 6-3).

USER INTERFACE: None. 


\section{TEMPERATURE DATA VISUALIZATION TOOL}

A PV-WAVE code was developed to view three-dimensional static and dynamic data. It was used for the current study to view static temperature data measured in wells at or near the INEL. Another PV-WAVE program (create_data_files.pro) was used to create data files in the proper format for the visualization tool.

create_data_files.pro

DESCRIPTION:

INPUT FILES:

METHODOLOGY:

SCREEN OUTPUT:

OUTPUT FILES:

USER INTERFACE:

Data Visualization Tool

DESCRIPTION:
This program creates data files to be used in the data visualization tool. For each well, a separate file containing temperature as a function of depth below the water table is created.

The input files to this program are data files for each well and a parameter file containing the following information for each well: well name, location (northing and easting), water table elevation $(\mathrm{m})$ and depth to the water table $(\mathrm{m})$. The data files for each well contain a list of sample depths $(\mathrm{m})$ and measured temperatures $\left({ }^{\circ} \mathrm{C}\right)$ at those depths.

The input data files for each well contain temperature data as a function of depth below the ground surface. The depth intervals vary from $1 \mathrm{~m}$ to a few meters and are not necessarily constant within the data file. The desired form of this data is temperature as a function of depth below the water table, given in 1-m depth intervals.

For each well, the temperatures at 1-m intervals below the water table are interpolated from the raw data in the input file. If data are not available, the temperature is set to zero. These interpolated temperature values are written to an output file.

None.

Output files are created for each well. For each depth, the files contain the depth $(\mathrm{m})$ below the water table, northing, easting, water table elevation $(\mathrm{m})$, and temperature $\left({ }^{\circ} \mathrm{C}\right)$. The depths range from $0 \mathrm{~m}$ (water table) to the maximum depth in 1-m intervals.

The user enters the maximum depth for the calculations.

The data visualization tool is a PV-WAVE application that provides various methods for interactively viewing three-dimensional data. Two applications can be used with the temperature data. The first application is the well log option. This application plots a twodimensional plot of temperature versus depth for a single well. 


\section{INPUT FILES:}

\section{SCREEN OUTPUT:}

OUTPUT FILES:

USER INTERFACE:
The second-application is the well path option. This application plots a three-dimensional plot of temperature versus depth for all wells.

The input files for this program are the data files created with the create_data_files.pro program and a parameter file that lists plotting parameters and well names.

If the well log option is selected, a window showing five plots is opened. The first and second plots show northing and easting versus depth. These are constant for the temperature data. The final three plots show temperature versus depth for three different temperature ranges. The ternperature ranges are specified in the parameter file. The plot backgrounds are colored according to the temperature at that depth interval. Within this option, the user can select another well to plot.

If the well path option is selected, a three-dimensional plot of well temperatures versus depth is drawn (Figure 8-1). A vertical line is drawn at each well location. The line is colored according to the temperature at each depth interval. A thin, white line is plotted wherever data were not available. The top of each line corresponds to the water table elevation for each well.

The well $\log$ plots and the well path plot can be saved as postscript files. In the well path plot, a gray line is plotted wherever data are not available, rather than a white line as in the screen output.

The user controls the visualization tool through series of windows, buttons, and slider bars. The initial option is to choose between STATIC and DYNAMIC data. For this application, only static data are available, so the STATIC button is selected. Next the user can select to view well logs or to view the well path plot. Within the well log option, the user can select the well to be displayed. In the well path option, the user can adjust the rotation angles. In either option, the plot can be saved as a postscript file. 


\section{HYDRAULIC GRADIENT CALCULATIONS}

A FORTRAN code (get_gradient.f) is used to calculate the hydraulic gradient and flow direction among three wells over time. A PV-WAVE code (plot_gradient_head.pro) is used to plot the gradient and flow direction versus time and the heads in each of the three wells versus time.

get_gradient.f

DESCRIPTION:

This FORTRAN program calculates the hydraulic gradient and flow direction in the vicinity of three wells.

INPUT FILES:

For each of the three wells, input files containing well name, date (integer number of days since January 1, 1900), hydraulic head (m), and well names and locations (northing and easting) is needed.

METHODOLOGY: $\quad$ First, the program identifies sample dates that are common to all three wells. For these dates, the hydraulic gradient and flow direction are calculated based on the hydraulic head measurements in each well and the location of each well (Tables 5-7 and 5-8).

SCREEN OUTPUT:

OUTPUT FILES:

USER NTERFACE:

plot_gradient_head.pro

DESCRIPTION:

INPUT FILES:

SCREEN OUTPUT:

OUTPUT FILES:

USER INTERFACE:
None.

The output is a text file containing the date (integer number of days since January 1, 1900), hydraulic gradient $(\mathrm{m} / \mathrm{m})$, flow direction $(0=$ south, $\pi 2=$ west $; \pi=$ north; $-\pi 2=$ east $)$; head $(\mathrm{m})$ in well 1 , head $(m)$ in well 2 , and head $(m)$ in well 3.

None.

This PV WAVE program plots results of the get_gradient.f program.

The output file from the get_gradient.f program and a parameter file containing plotting parameters are the input files to this code.

Two plots are shown on the screen: (1) plot showing hydraulic gradient versus time (scale on left axis) and flow direction versus time (scale on right axis); (2) plot showing head in each well versus time. Symbols are used to identify data used in the hydraulic gradient calculation.

The two output files created by this code are postscript files of the plots shown on the screen.

None. 


\section{BIBLIOGRAPHY}

A Hypercard application is used as a bibliography for references used in the WAG 10 Modeling Project.

DESCRIPTION:

INPUT FILES:

SCREEN OUTPUT:
The bibliography application contains one control card and an information card for each reference. The control card has function buttons that allow the user to sort, export bibliographies, and count reports. The information card is similar to a card catalog card.

None.

The screen output is a card for each reference. The card lists the report author, title, publication year, number of pages, abstract, sponsor, description of reference, bibliography, and a three identifiers. The first identifier is labeled'Tag.' It describes the main category of the report and can have the following labels:

$\begin{array}{ll}\text { CLIM } & \text { Climate } \\ \text { CONT } & \text { Contamination and contaminant sources } \\ \text { GEOL } & \text { Geology } \\ \text { GEOP } & \text { Geophysics } \\ \text { GEOT } & \text { Geothermal } \\ \text { GWHY } & \text { Groundwater hydrology } \\ \text { HYDRO } & \text { Surface water hydrology } \\ \text { MISC } & \text { Miscellaneous } \\ \text { SEIS } & \text { Seismology }\end{array}$

The second identifier list the subcategory that identifies the physical area addressed in the report. It can have the following labels:

$\begin{array}{ll}\text { BL } & \text { Big Lost River } \\ \text { Birch } & \text { Birch Creek } \\ \text { LL } & \text { Little Lost River } \\ \text { ML } & \text { Mud Lake } \\ \text { Reg } & \text { Regional } \\ \text { RM } & \text { Regional Modeling } \\ \text { Site } & \text { INEL } \\ \text { SM } & \text { INEL Modeling } \\ \text { W } & \text { Wells }\end{array}$

The final identifier lists the physical location of the report.

OUTPUT FILES:

Output files that can be created include bibliography of all reports sorted by author, category, or subcategory; bibliography of all 
reports in one category or subcategory; or bibliography of selected reports.

USER INTERFACE: $\quad$ The user can choose various functions defined by the buttons on the control card. These include the following:

Sort by author

Sort by category

Sort by subcategory

Export all

Export category

Export subcategory

Export marked

Count reports
Sort information cards alphabetically by author Sort information cards by category

Sort information cards by subcategory

Write a bibliography of all reports

Write a bibliography of all reports in a category

Write a bibliography of all reports in a subcategory

Write a bibliography of selected reports

Counts the number of reports in a category 


\section{WELL CORRELATION}

Two approaches have been developed to analyze well correlation. The first approach compares head measurements in two wells using a PV-WAVE code (head_head_plots.pro). This approach does not account for any time lag and, therefore, is only useful for comparing wells with relatively small distances separating them.

The second approach compares the Fast Fourier Transform (FFT) of head in wells using a series of PV-WAVE codes. To compute the FFT of a data set, the data must be presented with a uniform time interval. Because head measurements were not taken at uniform time intervals, head values must be interpolated.

A PV-WAVE code (spline_fit.pro) computes the best-fit spline for head versus time measurements for each well and uses the spline to estimate head values at uniform time intervals. Another PV-WAVE code (spline_well.pro) can be used to visually compare the measured data with the computed spline to determine whether an appropriate spline was generated.

A PV-WAVE code (fft.pro) computes the FFT of the head data for each well based on the results of the spline-fit program. Three PV-WAVE codes can be used to analyze the results of the FFT. A contour plot showing the maximum amplitude is created using plot_peak_amplitude.pro. Contour plots of FFT amplitude at given frequencies are created using wg_signal_cont.pro. Contour plots of well correlation based on FFT results can be plotted using wg_corr_matrix.pro

head_head_plots.pro

DESCRIPTION:

This PV-WAVE program plots head in well 1 versus head in well 2.

INPUT FILES:

For both wells, an input file containing well name, date (integer number of days since January 1,1900), and hydraulic head ( $\mathrm{m})$ is needed.

METHODOLOGY:

First, the program identifies sample dates that are common to both wells. For these dates, the head in well 1 is plotted versus the head in well 2. A least squares regression model is fit to the plotted points.

SCREEN OUTPUT: $\quad$ A head versus head plot showing the measured heads and the best-fit line is shown on the screen. In addition, the slope of the line and the $r^{2}$ of the regression is shown on the plot.

OUTPUT FILES: The plot shown on the screen can be saved as a postscript file.

USER INTERFACE: None. 
spline_fit.pro

DESCRIPTION:

INPUT FILES:

METHODOLOGY:

SCREEN OUTPUT:

OUTPUT FILES:

USER INTERFACE:

spline_well.pro

DESCRIPTION:

INPUT FILES:

METHODOLOGY:
This PV-WAVE program computes the spline that best approximates the hydrograph for each well.

For all wells, an input file containing well name, date (integer number of days since January 1,1900 ), and hydraulic head (m) is needed.

For each well, spline fits are computed by varying the spline space dimension until the best-fit criteria are met. Using this best-fit spline, head values as a function of time (uniform intervals) are computed and output. The spline space dimension is adjusted until one of the following criteria is met:

- $\quad$ For each measurement, the fitted heads does not differ from the measured head by more than $0.5 \times\left(h_{\max }-h_{\min }\right)$, where $h_{\max }$ is the maximum measured head for that well and $h_{\min }$ is the minimum measured head for that well.

- The next incremental spline space dimension would cause an unacceptable variation in slope of the fit. The variation in slope is assumed to be acceptable if the fitted head value for any midpoint, $h_{\mathrm{t} 1 / 2}$, between two measured head values, $h_{\text {to }}$ and $h_{\mathrm{t} 1}$, falls within: $h_{\mathrm{t} 0}-0.5 \times\left(h_{\max }-h_{\min }\right)$ $x h_{t 1 / 2} x h_{t 1}+0.5 \times\left(h_{\max }-h_{\min }\right)$, where $h_{t 0}$ is the smaller of the two measurements and $h_{t 1}$ is the larger of the two measurements.

None.

For each well, a file containing spline parameters and head values versus time is saved.

None.

This PV-WAVE program plots the spline fit for a given data set based on user-controlled spline parameters.

An input file containing sample date (integer number of days since January 1,1900 ), and hydraulic head $(\mathrm{m})$ for one well is needed.

The user can vary the spline parameters to test a fit for a specified data set. The resulting spline fit is plotted with the measured data. 
SCREEN OUTPUT:

OUTPUT FILES:

USER INTERFACE:

fft.pro

DESCRIPTION:

INPUT FILES:

METHODOLOGY:

SCREEN OUTPUT:

OUTPUT FILES:

USER INTERFACE:

plot_peak_amplitude.pro

DESCRIPTION:

INPUT FILES:

SCREEN OUTPUT:

OUTPUT FILES:

USER INTERFACE:
A plot showing spline fit and measured data is shown on the screen. In addition, slider bar controls for adjusting the spline parameters are shown on the screen.

None.

The user can adjust the spline parameters.

This PV-WAVE program computes the FFT of the results of the spline_fit.pro program for each well.

The input files for this program are the output files from the spline_fit.pro program.

Based on the fitted heads from the spline_fit.pro program, the FFT of the data is calculated. In addition, the peak amplitude of the FFT and the frequency corresponding to the peak amplitude are calculated.

Two plots are shown on the screen-one of the fitted head versus time and one of the FFT.

The plots shown on the screen are saved as a postscript file. For each well, a file listing amplitude as a function of frequency is written. In addition, a file is written that lists each well name, the peak amplitude of its FFT, and the frequency corresponding to this peak amplitude.

None.

This PV-WAVE program plots contours of maximum amplitude of FFT for each well.

The input file for this program is the output file from the fft.pro program that lists each well name, the peak amplitude of its FFT, and the frequency corresponding to this peak amplitude.

A color plot of peak amplitude contours is shown on the screen.

The plot shown on the screen is saved as a black-and-white postscript file.

None. 
wg_signal_cont.pro

DESCRIPTION:

INPUT FILES:

METHODOLOGY:

SCREEN OUTPUT:

OUTPUT FILES:

USER INTERFACE:

wg_corr_matrix.pro

DESCRIPTION:

INPUT FILES:

METHODOLOGY:

SCREEN OUTPUT:

OUTPUT FILES:

USER INTERFACE:
This PV-WAVE program plots contours of amplitude of FFT for each well for a specified frequency.

The input file is a file containing FFT amplitudes for each well for specified frequencies.

The user can select a frequency from a prespecified list of frequencies. A contour plot of amplitude of the FFT for each well is plotted for the selected frequency.

A color plot showing contours of the amplitude of the FFT for each well is plotted for the selected frequency. In addition, a list of allowable frequencies is shown.

The plot shown on the screen can be saved as a black-and-white postscript file.

The user can select the desired frequency value to be plotted.

This PV-WAVE program plots correlation contours for a specified well based on the results of the FFTs for each well.

The input file contains FFT amplitudes for each well for a series of frequencies.

The covariance of each well with respect to all others is calculated based on the FFT amplitudes in the input file. The user can select the reference well, and contours of the covariance of each well with respect to the reference well are plotted.

A color plot showing covariance contours is shown for the selected reference well. In addition, a list of wells is given from which the user can choose another reference well.

The plot shown on the screen can be saved as a black-and-white postscript file.

The user can select the desired reference well. 


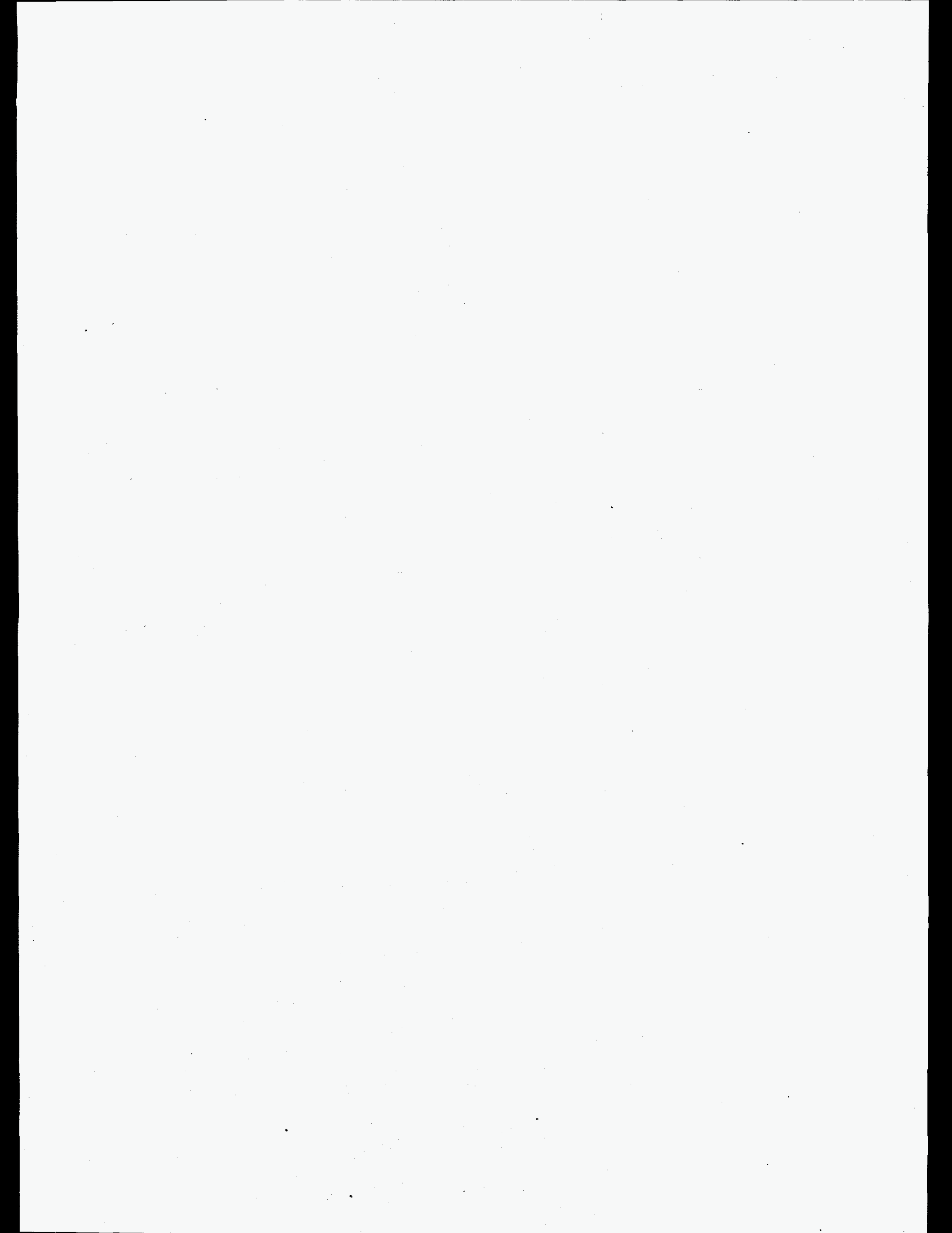


Appendix D

Record of Comments Review 



\author{
Water Resources Division \\ INEL Project Office, MS 4148 \\ P.O. Box 2230 \\ Idaho Falls, ID 83403
}

\author{
Donna Nicklaus \\ DOE/IDOPE/OSH \\ 785 DOE E-6 \\ Idaho Falls, ID
}

\title{
Dear Donna,
}

Thank you very much for the opportunity to review this manuscript. I reviewed selected technical aspects of the modeling process, particularly sections 3,4, and 5. Throughout the report, I found that terminology was used incorrectly (for example, depth instead of thickness) and the numerical modeling process was confused with the development of the conceptual model. I offer the following specific comments.

Page 3-1, Introductory paragraphs to the Conceptual Model--This section should provide a description of the conceptual model. However, throughout the section and subsequent sections, there is a lot of description of the numerical model. I believe that the conceptual model should be our best statement of the way the flow system works. Because of limited information, this statement is going to be highly simplified with a lot of assumptions. The numerical model is a tool that tests whether the conceptual model is physically or chemically possible. I would clean this section up and remove any discussion about the numerical model.

Page 3-1, First paragraph under Model Domain--I believe that the aquifer depth of 500 to 4,000 $\mathrm{ft}$ really is the aquifer thickness. Also, I encourage the use of the term "range" instead of "vary" when talking about spatial changes. The water level in a well may vary, but the thickness of the aquifer will range.

Page 3-1, Second paragraph under Model Domain--As far as I know, MODFLOW is considered to approximate 3-D flow. Again, here is the confusion between conceptual and numerical models.

Page 3-1, Third paragraph under Model Domain--This paragraph, in a very circuitous fashion, states that they used the same layering scheme that Garabedian used. I had a lot of trouble understanding, again, why they are discussing the numerical model in the conceptual model section.

Page 3-2, Ilustration--Are the contours really of the depth (from land surface) or of the thickness of the aquifer?

Page 3-3, Second paragraph under Water Budget--In the bulleted list, I am unaware of transpiration from a lake surface. This should be Lake evaporation.

Page 3-3, Second paragraph under 3.2.1 Snake River--I suggest that the authors add the phrase "from springs" after "discharged". Otherwise, it is unclear what we are talking about.

Page 3-7, First paragraph, sentence beginning "The river bed conductance"--I suggest that the authors state the conductance defines the capability of the riverbed material to conduct water between the river and the aquifer.

Page 3-7, Section 3.2.2, Streams, Canals, Lakes, and Ponds--If the estimates of stream and canal water losses are a significant portion of the budget, the means of estimating them should be defined. 
Page 3-7, Section 3.2.2.1 Recharge from the Big Lost River, sentence beginning with "Data on flow rates..."--I suggest that you replace "USGS river gauging electronic files" with "USGS river discharge data".

Page 3-7, Section 3.2.2.1 Last paragraph--Stream losses from the Big Lost River are mentioned as occurring before reaching the current model boundary. Are these losses accounted for as underflow into the SRPA?

Page 3-14, Section 3.2.4 Last paragraph--The discussion of recharge again looks more like a discussion of the numerical model rather than a discussion about the conceptual model.

Page 3-17, Section 3.2.6, first paragraph--add the word "that" after acre-ft.

Page 3-17, Section 3.3, first paragraph--I don't think that flow necessarily is in the interflow zones alone. I would add "and through fractures in the basalt". Again, here are more "numerical model" discussions in the Conceptual model section.

Page 3-27, Paragraph 2--The vertical conductance term used in MODFLOW is in $\mathrm{t}^{-1}$ units. Perhaps, instead of vertical conductances, they are talking about vertical hydraulic conductivity.

Page 3-27, Paragraph 4 and subsequent paragraphs--Apparently Garabedian and Spinazola developed the distribution of horizontal hydraulic conductivity based on surficial soil description. This report should describe the criteria used to come up with the EIS and WAG-10 model distributions. Also, you need to describe the physical system that would permit the decrease of $\mathrm{K}$ with depth. Are the ratios used plausible in light of the physical framework? In paragraph on page 3-32 beginning with "In the current model the....", transmissivity is not calculated by multiplying the $\mathrm{K}$ by the aquifer depth but by the aquifer thickness.

Page 4-1, Section 4.1.1, Paragraph 3--In numbered subparagraph 1, was the grid refined to 1X1 mile throughout the model? Also, numbered subparagraph 2 seems to be redundant to subparagraph 1.

Page 4-8, Section 4.1.3--The definition of all layers as confined seems to contradict page 3-32 in which layer 1 is defined as unconfined. Also, there is again a problem with confusion between conductance ( $\mathrm{t}^{-1}$ units) and hydraulic conductivity ( $\mathrm{t}^{-1}$ units).

Page 4-17, Section 4.2.3--Previously, parameter estimation techniques are described. Now K's from previous models are integrated. Sounds contradictory to me. Also, in paragraph 2, the new layer is described as $1,200 \mathrm{ft}$ deep. Is this supposed to be depth or thickness?

Page 5-3, Section 5.1.1--In subparagraph 3, by what criteria were zones defined. By this, did they use geologic, stratigraphic, grain-size, etc.?

Thanks again for the opportunity to review the report. I feel that it requires additional work before it is released. Larry Mann and Dan Ackerman would like to look at the report but have not had the time as of yet. If you have any questions regarding my comments, please give me a call.

Sincerely,

Brennon R. Orr Hydrologist

cc: District Chief INEL Project Chief 


\section{RECORD OF COMMENTS - Idaho Dept. of Health and Welfare, Div. of Environmental Quality}

Development of a Regional Groundwater Flow Model for the Area of the Idaho National Engineering Laboratory, Eastern Snake River Plain Aquifer, By J. M. McCarthy, R. C. Arnett, R. M. Neupauer, M. J. Rohe, and C. Smith

Comment Date: $\quad$ November 18, 1994

Response Date: $\quad$ December 5, 1994

\begin{tabular}{|c|c|c|c|c|}
\hline Item\# & Sec\# & Page\# & General Comments & $\begin{array}{r}\text { Resolution } \\
\end{array}$ \\
\hline 1 & & & $\begin{array}{l}\text { Conceptual Approach: The current model } \\
\text { employs } 4 \text { layers to represent the active portion of } \\
\text { the Eastern Snake River Plain Aquifer. A finer } \\
\text { finite difference grid ( } 1 \text { mile by } 1 \text { mile) is } \\
\text { employed than was used ( } 4 \text { mile by } 4 \text { mile) by } \\
\text { Garabedian (1992). The upper layer is envisioned } \\
\text { to behave as a unconfined system with a } \\
\text { storativity of } 0.1 \text { (page } 3-32 \text { ) for transient } \\
\text { simulations. The lower layers are assigned a } \\
\text { storativity of } 1 \text { X } 10^{-4} \text { for transient simulations. } \\
\text { Transmissivities are assigned based on hydraulic } \\
\text { conductivities (K) and zones of similar rock types. } \\
\text { MODFLOWP, a parameter estimation code, was } \\
\text { used to adjust the K values to reflect head } \\
\text { distributions at selected wells. The approach used } \\
\text { in the current model is based primarily on } \\
\text { previous modeling work by Garabedian (1992) } \\
\text { and Spinazola (1994a \& b). The multilayer } \\
\text { approach is appropriate but the selected value for } \\
\text { the storativity of the shallowest layer requires } \\
\text { more justification than is presented in the } \\
\text { document under review. }\end{array}$ & $\begin{array}{l}\text { There is very little information available from } \\
\text { pumping tests to define the storativity of the } \\
\text { aquifer. We initially chose } 0.1 \text { because it was } \\
\text { found in past modeling efforts to be reasonable } \\
\text { and it is in the range used by Garabedian and } \\
\text { Spinazola. The transient parameter estimation } \\
\text { (Section } 5.2 .1 \text { ) showed that a value of } 0.08 \text { gave a } \\
\text { better fit to the hydraulic head data. Note that the } \\
\text { regional model is simulated as four confined layers } \\
\text { with the upper layer storativity set to a value that } \\
\text { simulates unconfined flow (a specific yield value). } \\
\text { The estimated specific yield from the large scale } \\
\text { pumping test is } 0.13 \text { (Wylie, et al., 1995). } \\
\text { Therefore, } 0.1 \text { is probably a reasonable estimate. }\end{array}$ \\
\hline
\end{tabular}


RECORD OF COMMENTS - Idaho Dept. of Health and Welfare, Div. of Environmental Quality

\begin{tabular}{|c|c|c|c|c|}
\hline Item\# & Sec\# & Page\# & Specific Comments & $\begin{array}{c}\text { Resolution } \\
\end{array}$ \\
\hline 2 & Tab 3-6 & $3-21$ & $\begin{array}{l}\text { Values presented in Table } 3-6 \text { for estimated } \\
\text { underflow from Garabedian (1992) are inaccurate } \\
\text { for most of the sources. Those values that do } \\
\text { match are for Camas Creek, Little Lost River, } \\
\text { Salmon Falls Creek, Raft River, Portneuf River, } \\
\text { and Willow Creek. Typically, the values in the } \\
\text { table will match the values in the cited reference if } \\
\text { round-off is considered but the information is not } \\
\text { presented in that manner by Garabedian (1992). } \\
\text { Please correct the table. Also, the remainder of the } \\
\text { referenced values should be checked for } \\
\text { consistency too. }\end{array}$ & $\begin{array}{l}\text { The underflow values reported are actually from } \\
\text { the Garabedian and Spinazola input files so strictly } \\
\text { speaking they are not taken from Table } 11 \text { in } \\
\text { Garabedian or Figure } 27 \text { in Spinazola. We feel the } \\
\text { discrepancies are insignificant rather than the } \\
\text { values being inaccurate and do not feel they need } \\
\text { to be corrected. }\end{array}$ \\
\hline$\overline{3}$ & 3.3 & 3-27 & $\begin{array}{l}\text { Aquifer Properties, right column, top } \\
\text { partial paragraph. } \\
\text { It is stated that "For the transient simulations, a } \\
\text { storage coefficient that represents the specific yield } \\
\text { must be used to simulate unconfined response to } \\
\text { transient boundary conditions." It is quite } \\
\text { common for the initial response to pumping to } \\
\text { appear as the response attributable to a confined }\end{array}$ & $\begin{array}{l}\text { We agree that the recent, long term test at the } \\
\text { RWMC should provide valuable insight into the } \\
\text { nature of transient responses in the shallow, active } \\
\text { portion of the ESRP aquifer. As discussed in } \\
\text { Wylie, et al., 1995, the initial response to pumping } \\
\text { indicates confined flow and it approaches an } \\
\text { unconfined response after approximately one day } \\
\text { of pumping. }\end{array}$ \\
\hline & & & $\begin{array}{l}\text { pumping may approach that of an unconfined } \\
\text { aquifer with time but the range of time needed is } \\
\text { dependent upon a number of factors. The recent, } \\
\text { long term test at the RWMC should provide } \\
\text { valuable insight into the nature of transient } \\
\text { responses in the shallow, active portion of the } \\
\text { Snake River Plain Aquifer. Additional } \\
\text { justification should be provided to support the use } \\
\text { of an unconfined aquifer storativity for the } \\
\text { shallowest layer of the aquifer. }\end{array}$ & $\begin{array}{l}\text { This model uses relatively large time steps that are } \\
\text { larger than the early confined response to pumping } \\
\text { and the calibration time period is } 10 \text { years. Model } \\
\text { transient calibration results indicate that } 0.08 \text { is the } \\
\text { best estimated of the storativity which implies flow } \\
\text { in primarily an unconfined aquifer. If a confined } \\
\text { storativity was appropriate, the transient calibration } \\
\text { would have resulted in a storage coefficient well - } \\
\text { below } 0.08 \text {. }\end{array}$ \\
\hline 4 & 4. & 4-1 & $\begin{array}{l}\text { Numerical model design. It is suggested that } \\
\text { a paragraph be inserted that describes the code } \\
\text { selection process that was used prior to the } \\
\text { modeling and development of this report. }\end{array}$ & $\begin{array}{l}\text { On page 1-4 Section 1.2, the code selection } \\
\text { document is listed as a part of the previous WAG } \\
10 \text { work. We do not disagree with the comment } \\
\text { but do not feel it warrants revising the document. }\end{array}$ \\
\hline
\end{tabular}




\begin{tabular}{|c|c|c|c|c|}
\hline Item\# & Sec\# & Page\# & Specific Comments & Resolution \\
\hline 5 & 5.5 & $5-23$ & $\begin{array}{l}\text { It is not clear why the current simulated heads are } \\
\text { compared to the Garabedian simulated heads } \\
\text { instead of contours interpreted from measured } \\
\text { heads. It seems more logical to compare modeled } \\
\text { heads to measured heads, not to modeled heads } \\
\text { from a previous modeling effort. The comparison } \\
\text { to Garabedian's work is useful but the focus of } \\
\text { comparative analysis is better served by } \\
\text { comparing model output to measured site data and } \\
\text { not to other model output. }\end{array}$ & $\begin{array}{l}\text { There are two main reasons we did not compare } \\
\text { the heads over the entire domain to contours } \\
\text { interpreted from measured heads. } \\
\text { 1. The measured head file that Garabedian used to } \\
\text { compare to his simulated results could not be } \\
\text { found and we did not have a task identified in our } \\
\text { scope of work to generate the set of observations } \\
\text { necessary to generate these contours. We could } \\
\text { not extend the project deadline and therefore could } \\
\text { not add any additional work scope to the project. } \\
\text { 2. The model calibration focuses on the area in } \\
\text { the vicinity of the INEL. There is no calibration } \\
\text { outside that area. Therefore we looked primarily at } \\
\text { how our modifications to the Garabedian's and } \\
\text { Spinazola's models changed the simulated head } \\
\text { values over the entire domain. }\end{array}$ \\
\hline 6 & Tab 5-10 & $5-39$ & $\begin{array}{l}\text { The column labeled "Percent Error"' is apparently } \\
\text { based on the difference between the predicted } \\
\text { gains and losses in the Snake River from this } \\
\text { modeling effort and the earlier effort by } \\
\text { Garabedian (1992). However, it is more } \\
\text { appropriate to calculate error based on the } \\
\text { differences between the predictions in this } \\
\text { modeling effort and measured values of gain and } \\
\text { loss. }\end{array}$ & $\begin{array}{l}\text { We agree that it is important to compare the model } \\
\text { solutions with the measured gains and losses, that } \\
\text { is why the measured values are included in the } \\
\text { table. However, the model calibration was limited } \\
\text { to the area around the INEL and we were } \\
\text { concerned with how much the solution away from } \\
\text { the INEL was influenced. Because we were using } \\
\text { Garabedian zone definition and parameter values in } \\
\text { the area of the aquifer around and directly } \\
\text { upstream of the Snake River we decided to } \\
\text { quantitatively compare to the Garabedian results. }\end{array}$ \\
\hline
\end{tabular}

\section{References not in the report}

Wylie, A. H., J. M. McCarthy, E. Neher, and B. D. Higgs, 1995, Large Scale Aquifer Pumping Test Results, Engineering Design File, INEL-95 012. 


\section{RECORD OF COMMENTS - US EPA Region 10}

Development of a Regional Groundwater Flow Model for the Area of the Idaho National Engineering Laboratory, Eastern Snake River Plain Aquifer, By J. M. McCarthy, R. C. Arnett, R. M. Neupauer, M. J. Rohe, and C. Smith

Comment Date: $\quad$ November 21, 1994

Response Date: $\quad$ December 5, 1994

\begin{tabular}{|c|c|c|c|c|}
\hline Item\# & Sec\# & Page\# & General Comments & Resolution \\
\hline & General & & $\begin{array}{l}\text { It is understood that a large-scale regional model } \\
\text { (encompassing the entire Eastern Snake River } \\
\text { Plain) based on the } 1992 \text { Garabedian model can } \\
\text { better simulate boundary conditions and overall } \\
\text { water budget than a small-scale model. However, } \\
\text { the regional model may not consider details for the } \\
\text { area of interest (the INEL) that will be necessary } \\
\text { in the eventual use of a model to predict risks to } \\
\text { receptors of concern. Estimates of hydraulic } \\
\text { conductivity, recharge and discharge of specific } \\
\text { areas (such as the Test Reactor Area and the Idaho } \\
\text { Chemical Processing Plant), and pumpage and } \\
\text { leakage term, for example, may suffer from use of } \\
\text { a regionally-focused model which lacks sufficient } \\
\text { sensitivity to local conditions. } \\
\text { The model calibration discussion indicates that the } \\
\text { simulated regional groundwater flow gradient and } \\
\text { directions are significantly different from observed } \\
\text { data at the individual WAG level. This may have } \\
\text { significant implications for use of regional model } \\
\text { at the individual WAG level. }\end{array}$ & $\begin{array}{l}\text { We agree that intermediate scale flow models will } \\
\text { be needed to incorporate the details that influence a } \\
\text { particular WAG area. The large scale flow model } \\
\text { can be used to define the boundary conditions of } \\
\text { the intermediate scale flow model but not on the } \\
\text { local scale (see Section } 9.0 \text { of the report). We } \\
\text { anticipate that the specific WAGs that required a } \\
\text { detailed model will either develop an intermediate } \\
\text { scale flow model with sufficiently fine } \\
\text { discretization in the area of the plume, to simulate } \\
\text { transport or develop; } \\
\text { 1. an intermediate scale flow model that uses the } \\
\text { regional scale model to define its boundary } \\
\text { conditions, and } \\
2 \text {. a submodel that will be used to simulate both } \\
\text { flow and transport at the local scale. }\end{array}$ \\
\hline
\end{tabular}




\begin{tabular}{|c|c|c|c|c|}
\hline Item\# & Sec\# & Page\# & Specific Comments & Resolution \\
\hline 2 & 2.2 .4 .6 & $\begin{array}{l}2-9 \text { and } \\
2-10\end{array}$ & $\begin{array}{l}\text { Section } 2.2 .4 .6 \text { summarizes the two key aquifer } \\
\text { properties (transmissivity and hydraulic } \\
\text { conductivity). Once the data are available, the } \\
\text { aquifer properties from the large-scale pumping } \\
\text { test conducted in the radioactive waste } \\
\text { management complex should be compared to these } \\
\text { values. }\end{array}$ & $\begin{array}{l}\text { Agree, from the large scale pumping tests data, } \\
\text { Wylie, et al., } 1995 \text { estimated a hydraulic } \\
\text { conductivity of } 9 \times 10^{3} \mathrm{ft} / \text { day (transmissivity of } \\
1.4 \times 10^{6} \mathrm{ft}^{2} / \text { day). The hydraulic conductivity } \\
\text { estimated in the upper layer of the WAG } 10 \text { model } \\
\text { for the area of the pumping test (zone } 54 \text {, see } \\
\text { Figure } 3-16 \text { ) is } 5 \times 10^{3} \mathrm{ft} / \text { day (Table } 5-5 \text { ). }\end{array}$ \\
\hline 3 & 3.2 .5 & $\begin{array}{l}3-21 \\
\text { through } \\
3-23\end{array}$ & $\begin{array}{l}\text { In Table 3-6 the underflow rates from different } \\
\text { drainage basins are presented. Table } 3-7 \text { also } \\
\text { presents underflow rates for the numerical model } \\
\text { (Column D). The values in Tables } 3-6 \text { and } 3-7 \\
\text { appear to be inconsistent. For example, total } \\
\text { estimated underflow rates for the current model is } \\
1,980.8 \mathrm{ft}^{3} / \mathrm{sec} \text { in Table } 3-6 \text { but } 1,970 \mathrm{ft}^{3} / \mathrm{sec} \text { in } \\
\text { Table } 3-7 \text {. Also, the distribution of the estimated } \\
\text { underflow for each drainage basin to different } \\
\text { grids of the numerical model is not clearly } \\
\text { specified. }\end{array}$ & $\begin{array}{l}\text { The data in Table 3-6 comes from Garabedian's } \\
\text { and Spinazola's input files and are assigned to } \\
\text { underflow reaches defined by Garabedian. The } \\
\text { underflow reaches shown in Table 3-7 were } \\
\text { defined separately and the person who defined } \\
\text { them did not realize that they should be consistent } \\
\text { with Garabedian's underflow reaches. In } \\
\text { addition, the underflow estimates used for Table 3- } \\
7 \text { were rounded off in some cases causing the total } \\
\text { underflow to differ by } 0.5 \% \text { from the underflow } \\
\text { shown in Table 3-6. We recognized these } \\
\text { inconsistencies too late to have the underflows } \\
\text { reallocated to be consistent with the underflow } \\
\text { reaches referred to in Table 3-6. We do not feel it } \\
\text { is necessary to update Table 3-7 to make it } \\
\text { consistent with 3-6 but we do think that it should } \\
\text { be noted that they are inconsistent. }\end{array}$ \\
\hline
\end{tabular}




\begin{tabular}{|c|c|c|c|c|}
\hline Item\#\# & Sec\# & Page\# & Specific Comments & Resolution \\
\hline 4 & 5.1 .3 & $\begin{array}{l}5-5 \text { and } \\
5-6\end{array}$ & $\begin{array}{l}\text { The text on these pages describes calibration } \\
\text { targets. As we have discussed previously, } \\
\text { technical accuracy for Superfund-inspired projects } \\
\text { should be linked to remedial data quality } \\
\text { objectives. For example, it is stated on p. 5-5 that } \\
\text { "the areal fit to steady state hydraulic heads must } \\
\text { be reasonable." A reasonable fit cannot be } \\
\text { properly defined without consideration for the } \\
\text { end-use of the model. }\end{array}$ & $\begin{array}{l}\text { The objectives and goals for the WAG } 10 \text { regional } \\
\text { groundwater modeling have been modified a } \\
\text { number of times in the past two years and at this } \\
\text { time specific, detailed objectives are not clearly } \\
\text { defined. This limited the focus of the modeling } \\
\text { effort and is the reason that the WAG } 10 \text { modeling } \\
\text { has been suspended. Further modeling is not } \\
\text { planned until the role of WAG } 10 \text { is more clearly } \\
\text { defined by the agencies and specific detailed goals } \\
\text { can be established. We expect that the present } \\
\text { effort will provide assistance in defining the } \\
\text { quantitative goals. } \\
\text { A paragraph has been added to Section } 5.1 .3 \text { that } \\
\text { states that the calibration targets are not necessarily } \\
\text { reasonable with respect to risk because the WAG } \\
10 \text { transport objectives have not be clearly defined. }\end{array}$ \\
\hline 5 & 5.2 .2 & $5-34$ & $\begin{array}{l}\text { Minor comment/suggestion (if the Tech Memo } \\
\text { were to be revised): } \\
\text { The flow direction should be provided in degrees } \\
\text { (e.g., north as } 0 \text { degrees, east as } 90 \text { degrees, } \\
\text { south as } 180 \text { degrees and west as } 270 \text { degrees). }\end{array}$ & $\begin{array}{l}\text { Agree, it would be easier for the reader to interpret } \\
\text { if the units were degrees rather than radians. We } \\
\text { will consider this if further calibration is needed. }\end{array}$ \\
\hline
\end{tabular}

\section{References not in the report}

Wylie, A. H., J. M. McCarthy, E. Neher, and B. D. Higgs, 1995, Large Scale Aquifer Pumping Test Results, Engineering Design File, INEL-95\012. 